MAGYAR ÉS NEMZETKÖZI NÉVTANI TERMINOLÓGIA

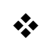

\title{
HUNGARIAN AND INTERNATIONAL ONOMASTIC TERMINOLOGY
}




\title{
HUNGARIAN AND INTERNATIONAL ONOMASTIC TERMINOLOGY
}

\author{
Edited by: \\ Andrea Bölcskei, Tamás Farkas, Mariann Slíz
}

International Council of Onomastic Sciences

Society of Hungarian Linguistics

Uppsala • Budapest

2017 


\title{
MAGYAR ÉS NEMZETKÖZI NÉVTANI TERMINOLÓGIA
}

\author{
Szerkesztette: \\ Bölcskei Andrea, Farkas Tamás, Slíz Mariann
}

International Council of Onomastic Sciences Magyar Nyelvtudományi Társaság

Uppsala • Budapest

2017 
Magyar és nemzetközi névtani terminológia Hungarian and International Onomastic Terminology

Szerkesztette: Bölcskei Andrea, Farkas Tamás, Slíz Mariann

Edited by: Andrea Bölcskei, Tamás Farkas, Mariann Slíz

A kötetet lektorálták: Bauko János, Fóris Ágota, Milan Harvalík

The volume has been peer-reviewed by: Ján Bauko, Ágota Fóris, Milan Harvalík

ISBN 978-615-5061-10-3 (print)

ISBN 978-615-5061-11-0 (online)

DOI: $10.26546 / 5061110$

A kötet megjelentetését támogatta a Magyar Nyelvstratégiai Intézet

Publication has been supported by the Institute for Hungarian Language Strategy

(C) A szerzők, a szerkesztők és az eredeti jogok birtokosai, 2017

(C) The authors, the editors and the owners of the original rights, 2017

Müszaki szerkesztő: Slíz Mariann

Technical editor: Mariann Slíz

Borítóterv: Szabó Panna és Slíz Mariann

Cover: Panna Szabó and Mariann Slíz

Kiadta / Published by:

International Council of Onomastic Sciences • Magyar Nyelvtudományi Társaság
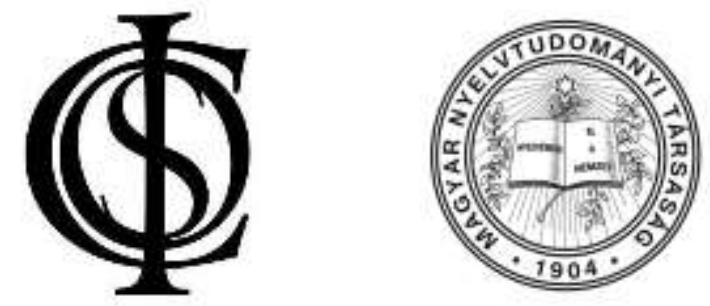


\section{Tartalom / Contents}

\section{ELÖSZÓK}

Előszó (Milan Harvalík) ........................................................................................... 9

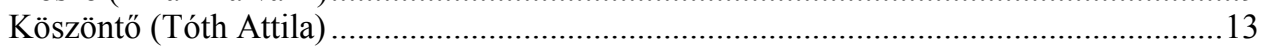

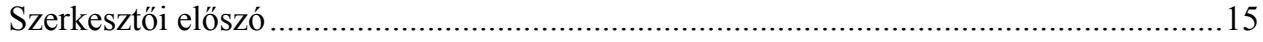

\section{FOREWORDS}

Foreword (Milan Harvalík) ................................................................................... 19

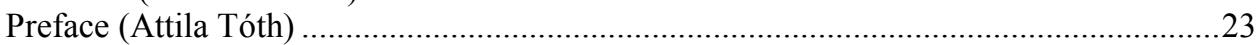

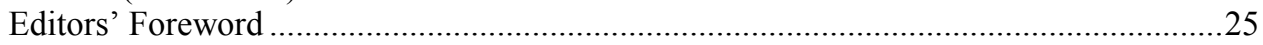

\section{TANULMÁNYOK}

Nemzetközi és magyar névtani terminológiai kutatások (Farkas Tamás) .........................29

Két nemzetközi névtani terminológiai jegyzék magyar változata (Bölcskei Andrea) .......... 49

\section{STUDIES}

Terminological Studies in International and Hungarian Onomastics (Tamás Farkas) .........65 The Hungarian Versions of Two International Onomastic Terminological Glossaries (Andrea Bölcskei)

\section{TERMINUSJEGYZÉKEK / GLOSSARIES OF TERMS}

AZ ICOS TERMINUSJEGYZÉKE ÉS MUTATÓI / THE ICOS LIST OF TERMS AND ITS INDICES

Alapvető névtani terminusok jegyzéke (Magyar változat) / List of Key Onomastic Terms (Hungarian Edition) ......................................................................... 101

Magyar-angol terminusmutató az ICOS-szójegyzékhez / Hungarian-English Term Index of the ICOS Glossary ................................................................................. 112

Angol-magyar-német-francia terminusekvivalenciák mutatója az ICOS-szójegyzékhez / Index of the English-Hungarian-German-French Term Equivalents

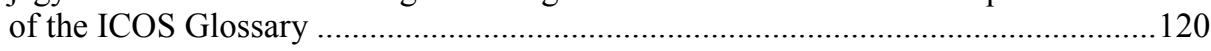

AZ UNGEGN TERMINUSJEGYZÉKE ÉS MUTATÓJA / THE UNGEGN GLOSSARY OF

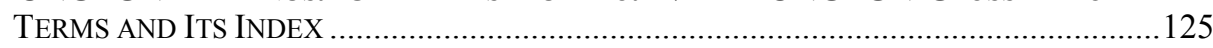

A földrajzi nevek egységesítése során használt terminusok jegyzéke (Magyar változat) / Glossary of Terms for the Standardization of Geographical Names (Hungarian Edition).

Magyar-angol terminusmutató az UNGEGN-szójegyzékhez / Hungarian-English Term Index of the UNGEGN Glossary 

Előszók 

BÖLCSKEI-FARKAS-SLíz szerk., Magyar és nemzetközi névtani terminológia. Hungarian and International Onomastic Terminology. International Council of Onomastic Sciences - Magyar Nyelvtudományi Társaság, Uppsala-Budapest, 2017. 9-11.

DOI: $10.26546 / 5061110.1$

\section{Elöszó}

A névtani terminusok alakulásmódjának, használatának és meghatározásának különféle kérdései évek óta a figyelem középpontjában vannak. Az, hogy az egyes kutatók a különféle terminusokat eltérő jelentésben használják, komolyan akadályozhatja egymás pontos megértését. A terminusokban való világos egyetértés, a standardizáció hiányában a névkutatók nem feltétlenül képesek a gondolatok cseréjére, a koncepciók megvitatására, a tudomány elöbbre vitelére, ami negatívan befolyásolja a szélesebb körü tapasztalatcserét, a nemzetközi együttmüködést és a névtan további fejlődését.

Mint BotOLV HELLELAND rámutat (HARVALÍK-CAFFARELLI 2007: 196), a névkutatás nemzeti tudományként indult, amelynek fó célja az írott és szóbeli névanyag, elsősorban a hely- és személynevek összegyüjtése, vizsgálata és megjegyzésekkel, magyarázatokkal ellátott közreadása volt. Nemzetközi terminológiára különösebb igény nem mutatkozott. Ez azonban az évek során megváltozott: napjainkban a névtan elméleti és módszertani problémáit nemzetközi színtéren, például nemzetközi kongresszusokon is megvitatják. Amikor pedig egy-egy tanulmányt vagy egyéb munkát nemzetközi közönségnek szánnak, elengedhetetlen, hogy a terminológia nemzeti hovatartozástól függetlenül, mindenki számára érthető legyen. Ez általában is érvényes a névtanra, az elméleti kérdések tárgyalásakor pedig különösen fontos. Ugyanígy érdemes nemzetközi szinten is érthető terminusokat használni a névtani kategóriák meghatározása során.

Az egységességnek a névtani terminológia használatában megfigyelhető hiánya azt a benyomást keltheti, hogy a névtan fejletlen diszciplína, ez pedig alááshatja a megbízhatóságát. Érdemes ugyanakkor megjegyezni, hogy a terminusok használatában és/vagy jelentésében tapasztalható eltéréseket nagyrészt az eltérő elméleti megközelítések és az egyes névtani iskolák, országok és nyelvek különböző hagyományai eredményezik, így országos szinten, egy adott nyelven vagy névtani iskolán belül nem különösebben gyakori a terminusok következetlensége, többértelmüsége vagy bizonytalansága.

A közös terminológia megalapozása már megtörtént, köszönhetően egy sor egy- és többnyelvü névtani terminológiai szótárnak és terminológiai rendszerezésnek. A névtani terminológia különös fontosságát tükrözi, hogy ezeken kívül olyan munkák is foglalkoznak vele, amelyek elsősorban a névtan általános kérdéseit tárgyalják vagy éppen egy-egy adott problémakört mutatnak be.

A legfőbb problémák, amelyekkel a különféle terminológiai rendszerekkel összefüggésben találkozunk, jelentkezhetnek abban, hogy ugyanazon jelenségre vagy névfajtára különböző terminusok vannak használatban, illetve hogy egymás mellett létezik egy hazai és egy nemzetközi terminuskészlet.

Nyilvánvaló, hogy a terminusok többértelmüsége és bizonytalansága zavarokat okozhat. Még ha a terminusok idővel pontossá és állandóvá válnak is, a megszilárdulásuk a 
folyamat koordinálása nélkül hosszú és bizonytalan kimenetelü lesz. Ezért a használatba vont terminológiának csapatmunka és közös megegyezés eredményének kellene lennie, sőt, talán egyfajta kötelező érvényűvé tétele is megfontolandó lehet. Ennek érdekében 2002-ben, a 21. Nemzetközi Névtudományi Kongresszuson Uppsalában javaslat született egy névtani bizottság felállítására a Nemzetközi Névtudományi Társaság (International Council of Onomastic Sciences, ICOS) védnöksége alatt azzal a céllal, hogy összeállítson egy, a használatban lévő névtani terminusokat definíciójukkal együtt tartalmazó nemzetközi útmutatót (HARVALÍK 2005). Ez a terminológiai munkacsoport, amely az ICOS vezetőségének égisze alatt müködik, annak 2004. március 24-27-i tanácskozásán jött létre; tagjai különböző nyelvek, országok vagy régiók és névtani iskolák képviselöi.

E bizottság tevékenységét HARVALÍK (2014) részletesen bemutatja, és e kötet is kitér rá röviden (BÖLCSKEI 2017, FARKAS 2017). A csoport munkájának legfőbb eredménye egy háromnyelvü, az ICOS hivatalos nyelvein (angol, német és francia) készült lista az alapvető névtani terminusokról, mely az ICOS honlapján érhető el (Icosweb Terminology). Jelenleg az egyik legfőbb feladat ennek a terminusjegyzéknek az elkészitése további nyelvekre, elérhetővé téve így a névkutatók szélesebb köre számára is. A cseh és szlovák változat már elkészült, egyéb nyelvüek összeállítása pedig folyamatban van. Örömmel tapasztalom, hogy a magyar változat - kiegészítve egy angol-magyar terminusmutatóval és egy angol-magyar-német-francia négynyelvü ekvivalencialistával - szintén elkészült, és elérhetővé válik e kötetben.

Ugyancsak fontos munka a névtani terminológia terén az ENSZ Földrajzi Névi Szakértői Csoportja (United Nations Group of Experts on Geographical Names, UNGEGN) által kidolgozott terminusjegyzék magyar változata, amely szintén e kiadványban jelenik meg.

Nemcsak a Nemzetközi Névtudományi Társaság és az ICOS Terminológiai Munkacsoportjának elnökeként, hanem névkutatóként is nagyra értékelem magyar kollégáim e kötetben közzétett munkáját. Eredményeik bizonyítják, hogy a különböző nyelvek és névtani iskolák által használt terminusok kölcsönös összehangolása - folyamatosan figyelembe véve azok valós használatát, elfogadva a pluralizmus jogát is - alapvetően hozzájárul az egyes névkutatók közötti, magasabb szintü megértéshez, és ösztönzőleg hat a névtan általános elméletének és alapelveinek további fejlődésére is.

\section{Hivatkozott irodalom}

BÖLCSKEI ANDREA 2017. Két nemzetközi névtani terminológiai jegyzék magyar változata. In: BölCSKei Andrea - Farkas Tamás - Slíz Mariann szerk., Magyar és nemzetközi névtani terminológia / Hungarian and International Onomastic Terminology. International Council of Onomastic Sciences - Magyar Nyelvtudományi Társaság, Uppsala-Budapest. 49-61. https://doi. org/10.26546/5061110.8

FARKAS TAMÁS 2017. Nemzetközi és magyar névtani terminológiai kutatások. In: BöLCSKEI ANDREA - FARKAS TAMÁS - SLÍz MARIANN szerk., Magyar és nemzetközi névtani terminológia / Hungarian and International Onomastic Terminology. International Council of Onomastic Sciences - Magyar Nyelvtudományi Társaság, Uppsala-Budapest. 29-47. https://doi.org/10.26546/ $\underline{5061110.7}$ 
HARVALíK, MiLAN 2005. Towards a new millennium - towards a common onomastic terminology? In: Brylla, Eva - Wahlberg, Mats eds., Proceedings of the 21st International Congress of Onomastic Sciences. Uppsala 19-24 August 2002. Språk- och folkminnesinstitutet, Uppsala. 1: $160-171$.

HaRvalík, Milan 2014. Towards a common onomastic terminology? The next step. In: TORT I Donada, JoAn - Montagut i Montagut, Montserrat eds., Els noms en la vida quotidiana. Actes del XXIV Congrés Internacional d'ICOS sobre Ciències Onomàstiques. / Names in daily life. Proceedings of the XXIV ICOS International Congress of Onomastic Sciences. Biblioteca Tècnica De Política Lingüística 11. Generalitat de Catalunya, Barcelona. 21-25. http://www.gen cat.cat/llengua/BTPL/ICOS2011/004.pdf és https://doi.org/10.2436/15.8040.01.4

HARVAlíK, Milan - CAFFARELLI, ENZO 2007. Onomastic terminology: an international survey / Terminologia onomastica: un'inchiesta internazionale. Rivista Italiana di Onomastica 13: 181-220.

Icosweb Terminology = ICOS Lists of Key Onomastic Terms. https://icosweb.net/drupal/terminology

MiLAN HARVALÍK a Nemzetközi Névtudományi Társaság (ICOS) elnöke 

BÖLCSKEI-FARKAS-SLíz szerk., Magyar és nemzetközi névtani terminológia. Hungarian and International Onomastic Terminology. International Council of Onomastic Sciences - Magyar Nyelvtudományi Társaság, Uppsala-Budapest, 2017. 13-14. DOI: $10.26546 / 5061110.2$

\section{Köszöntő}

A Magyar Nyelvstratégiai Intézet igazgatójaként tisztelettel köszöntöm a kötet olvasóit. Külön öröm és megtiszteltetés számomra, hogy a kiadvány olyan kivételes alkalomra készült el, mint a 26. Nemzetközi Névtudományi Kongresszus, amelynek először ad otthont Magyarország, a Debreceni Egyetem. Az, hogy ezt a háromévenként megrendezésre kerülő konferenciát hazánk rendezi meg, az itthoni névtannal foglalkozó kutatók kitűnő szakmai elismeréseként könyvelhető el a nemzetközi tudományos szférában, s azt bizonyítja, hogy a hazai névkutatás egyre növekvő nemzetközi látókörrel és kapcsolatrendszerrel rendelkezik.

A Magyar Nyelvstratégiai Intézetet - amely a Miniszterelnökség irányításával működő központi hivatal - 2014. március 4-én hozta létre a Kormány azzal a céllal, hogy tanácsadó testülete legyen a nyelvi, nyelvpolitikai kérdésekben, és a teljes magyar nyelvterületet, a nemzet egységét szem előtt tartva kidolgozza a magyar nyelvstratégiát. A nyelvstratégia fontos részének és az intézet egyik feladatának is tartom a különböző szaknyelvek (terminológiák) tudatos fejlesztésének koordinálását, a határon túli és az anyaországi magyar nyelvü terminológia összehasonlító kutatását, valamint összehasonlító terminológiai szótárak összeállítását. Mindezek miatt volt fontos támogatni a Magyar és nemzetközi névtani terminológia / Hungarian and International Onomastic Terminology címü kötet kiadását, mely az Eötvös Loránd Tudományegyetem és a Károli Gáspár Református Egyetem névkutatóinak együttmüködésében készülhetett el.

$\mathrm{Az}$ onomasztika nyelvtudományunk egyik legdinamikusabban fejlődő területe, $\mathrm{s}$ mégis mint minden tudományterületnek, ennek a tulajdonnevekkel foglalkozó diszciplínának is vannak terminológiai problémái, amelyek - reményeim szerint - az e tárgykörben rendezett szakmai konferenciákon mielőbb megoldódnak majd.

A szaknyelv és terminológia fejlesztése ma olyan odafigyelést érdemlö terület, amelynek eredménye az állampolgárok számára is hasznosítható: segíti a könnyebb megértést, csökkenti a bürokráciának való kiszolgáltatottságot, növeli az egyén és a közösség magabiztosságát és önrendelkezésének hatékonyságát, valamint hozzájárul a társadalom költséghatékonyabb müködéséhez.

Nemzeti nyelvünk az identitás, a kommunikáció és a megismerés eszköze is. Az egyén és a közösség akkor tudja a legjobban használni anyanyelvét és gyakorolni anyanyelvhasználatához való jogát, ha ehhez biztosítottak a feltételek; többek között létezik az adott nyelven pontos, szabatos, szakemberek által összehangolt és ellenőrzött terminológia. Elengedhetetlenül fontos, hogy a létrehozott terminológiai adatbázisok széles körben hasznosuljanak, azaz - ha lehetséges - ingyenesen hozzáférhetőek legyenek online szótárakban vagy nyilvános adatbázisokban. Az UNESCO-irányelvekben is deklarált terminológiai tervezés részeként a jövő szempontjából szükséges tehát a szaknyelvek innovatív fejlesztése. 
A kutatómunkában fontos lépés annak a két nemzetközi névtani terminológiai szójegyzéknek a magyar változata, amelyet jelen kötet tartalmaz, s amit stratégiai szempontból különösen nagyra értékelek. Mind a névtan alapvetö, elsősorban a szükebb szakmai kommunikáció során alkalmazott szakkifejezéseinek, mind pedig a földrajzinévegységesítési tevékenység során használatos nyelvészeti, földrajzi, térképészeti, dokumentációs és információtechnológiai vonatkozású terminusoknak a jegyzékét hiánypótlónak gondolom.

Bár létezik egyéni és intézményi keretek között folyó terminológiatervezés, a tudományos igénnyel összehangolt terminológiapolitikai tevékenység és gondolkodás ma még gyakran hiányzik. Nagyon fontos, hogy ennek a tevékenységnek legyen müködőképes intézményrendszere, amely - hasonlóan más országokhoz - tartozhat például az Országgyülés alá, vagy egyéb, tudományos intézményekhez. Magyarországon tanácsadó szerepet lát el az UNESCO alszervezeteként müködö Magyar Nyelv Terminológiai Tanácsa, de fontos terminológiai mühely még például a Károli Gáspár Református Egyetem Terminológiai Kutatócsoportja vagy a Kárpát-medencei nyelvi intézeteket tömörítő Termini Magyar Nyelvi Kutatóhálózat, mely utóbbinak a kutatásai között a szaknyelvi és a terminológiai kérdések is meghatározóak.

A szaknyelvek és a terminológiák szisztematikus fejlesztése és a más nyelvekkel való terminológiai harmonizáció feladatának ellátása nagy ívü, hasznos és hiánypótló feladat, amely csak közösen, szakmai és döntéshozói összefogással valósulhat meg. Ehhez a 26. Nemzetközi Névtudományi Kongresszus angol, német és francia nyelvü nemzetközi seregszemléje, továbbá a Nemzetközi Névtudományi Társaság névtani terminológiával foglalkozó szakembereinek tevékenysége kitűnő szellemi muníciót szolgáltat.

TÓTH ATTILA

a Magyar Nyelvstratégiai Intézet igazgatója 
BÖLCSKEI-FARKAS-SLÍZ szerk., Magyar és nemzetközi névtani terminológia. Hungarian and International Onomastic Terminology. International Council of Onomastic Sciences - Magyar Nyelvtudományi Társaság, Uppsala-Budapest, 2017. 15-16. DOI: $10.26546 / 5061110.3$

\section{Szerkesztői előszó}

A megfelelő tudományos terminológia szoros és kölcsönös viszonyban áll tárgyával. A terminológiai bizonytalanságok, tisztázatlanságok megnehezítik egy adott terület vagy témakör átlátását, megértését; a felmerülő kérdések tisztázását, elméleti továbbgondolását; a tudományos eszmecserét, a különböző kutatások egymáshoz illeszkedését, gyakorlati alkalmazását. Azaz: az adott tudományág fejlődését és hasznosulását, nemzeti és nemzetközi szinten egyaránt. A tapasztalat ugyanakkor azt mutatja, hogy a különböző nyelvek és kultúrák, az egyes szaknyelvek, s akár egyazon szakterület szakirodalmai is számottevő eltéréseket mutatnak a használatban lévő terminológia tekintetében. A fentebbiek szempontjából fontos azonban feltérképezni e különbségeket, a vizsgálat alá vont terület fogalmi rendszerének jellemzőivel együtt. A szakmai kommunikáció zavartalanságának biztosítása érdekében pedig érdemes törekedni a konszenzusra a fogalmakat jelölő terminusok formájában, jelentésében, logikai kapcsolataiban, állományában és használati szabályaiban egyaránt.

A névtani ismeretek elméleti és gyakorlati felhasználásának több tudomány-, illetve szakterülethez köthetősége nem lehet kétséges. A nyelv-, a fordítás-, az irodalom-, a történet-, a jog-, a közlekedés- és a földrajztudomány, a térképészet, a könyvtár- és információtudomány, a hírközlés és tömegkommunikáció, a közigazgatás - hogy csak a legnyilvánvalóbbakat említsük - például számos szempontból kapcsolódik a tulajdonnevek különböző típusainak, illetve alkalmazásainak problematikájához. A nyelvtudományi részdiszciplínák közül a névtan terminológiájának nemzeti nyelvű és nemzetközi rendezése, harmonizációja ezért különösen is szükséges és időszerű feladatnak tekintendő.

Amint tapasztalhatjuk, a terminológia iránti általános érdeklődés a nemzetközi tudományosságban és Magyarországon is megélénkült az utóbbi időkben. Ez szükebb területünkön, a névkutatásban is érzékelhető. Magyarországon ugyanakkor a korszerü terminológiai szótárak és/vagy adatbázisok terén jelentős hiányosságokkal szembesülhetünk általában a humán tudományok, s így a nyelvtudomány esetében is. Számos nyelven állnak rendelkezésre kisebb vagy nagyobb, illetve átfogó igényű nyelvészeti, illetőleg névtani terminológiai szótárak, Magyarországon azonban inkább csak korlátozottabb célkitűzésű munkákról adhatunk számot.

A nemzetközi névtani terminológiai munkálatok eddigi legjelentősebb eredményének két többnyelvü terminusjegyzék tekinthető. Az egyik a Nemzetközi Névtudományi Társaság (International Council of Onomastic Sciences, ICOS) terminológiai munkacsoportjának a munkája, az alapvető névtani terminusok angol-német-francia nyelvű listája. A másik a földrajzi nevek egységesítésében használt szakkifejezéseket tartalmazó jegyzék, az ENSZ Földrajzi Névi Szakértői Csoportjának (United Nations Group of Experts on Geographical Names, UNGEGN) köszönhető terminológiai lista. 
A jelen kiadványban e két aktuális nemzetközi névtani terminológiai jegyzék magyar változatát és a hozzájuk kapcsolódó többnyelvü terminusmutatókat adjuk közre. A jegyzékek és mutatók projektmunkák keretében, többek közremüködésével készültek el. A terminusjegyzékeket két, magyar és angol nyelvü változatban is közölt tanulmány kíséri. FARKAS TAMÁS írása a nemzetközi, idegen nyelvü és a magyar névtani terminológiai munkálatok történetét, főbb irányait és területeit, illetve eredményeit tekinti át, BÖLCSKEI ANDREA tanulmánya pedig a két terminusjegyzéknek és magyar változatuknak a történetét, tartalmát és felépítését, elkészítésük sajátos problematikáját és elkészítőit mutatja be.

A kötet az ICOS 2011-es barcelonai kongresszusa nyomán, az ICOS terminológiai munkacsoportjához kapcsolódóan megalakult magyar albizottság, illetve az ennek kapcsán is megformálódott alkalmazott névtani kutatócsoport tevékenységének eredménye. A kapcsolódó munkálatok a Károli Gáspár Református Egyetem Magyar Nyelvtudományi Tanszékén és az Eötvös Loránd Tudományegyetem Magyar Nyelvtörténeti, Szociolingvisztikai, Dialektológiai Tanszékén folytak. A megjelent kiadvány szakmai hitelességét a több tudományterületet képviselő lektorok munkája volt hivatott biztosítani. A kötetet terminológiai szempontból FóRIS ÁGOTA (Budapest), a nemzetközi és a magyar névtudomány oldaláról pedig MILAN HARVALÍK (Prága) és BAUKO JÁNOS (Nyitra) lektorálta. Az UNGEGN helynév-standardizációs terminológiai szójegyzékének magyar változatát számos kapcsolódó szakterület képviselője véleményezte. A kötet kiadására az ICOS és a Magyar Nyelvtudományi Társaság közösen vállalkozott.

A kiadványhoz írt előszavában MILAN HARVALíK, az ICOS elnöke, valamint e szervezet terminológiai munkacsoportjának kezdeményezője és vezetője a nemzetközi névtani terminológiai munkálatok történetéről és fontosságáról fogalmazta meg gondolatait. TóTH ATTILA, a kötet megjelentetését támogató Magyar Nyelvstratégiai Intézet (Manysi) igazgatója pedig a szaknyelvek, illetve a nemzeti nyelvü terminológia gondozásának fontosságára hívta fel a figyelmet.

E kötet szerkesztőiként ezúton is köszönetünket fejezzük ki mindazoknak, akik munkájukkal segítették elkészítését. Köszönettel tartozunk az ICOS, illetve az UNGEGN eredeti terminusjegyzékeit összeállító és megjelentető szakembereknek. S köszönjük a Manysinak és vezetésének, hogy anyagilag támogatták e kiadvány megjelentetését.

A kétnyelvü kötetet mind hagyományos, nyomtatott formában, mind pedig elektronikusan, az interneten, szabad hozzáférésü kiadványként közzétesszük. A célunk az, hogy a terminusjegyzékek és a kapcsolódó információk minél szélesebb körben, több tudományterületen, magyar és nemzetközi szinten is hasznosulhassanak, megkönnyítve ezzel a magyar és külföldi névkutatók, valamint a nevekkel foglalkozó különböző szakterületek képviselői közötti kommunikációt, tovább erősítve a szakmai kapcsolatokat, a közös kutatásokat, a magyar nyelvü és a nemzetközi tudományosság fejlődését.

A SZERKESZTÖK 


\section{Forewords}



BÖLCSKEI-FARKAS-SLÍz eds., Magyar és nemzetközi névtani terminológia. Hungarian and International Onomastic Terminology. Uppsala-Budapest: International Council of Onomastic Sciences - Magyar Nyelvtudományi Társaság, 2017. 19-21. DOI: $10.26546 / 5061110.4$

\section{Foreword}

Various aspects of the formation, use and definition of onomastic terms are problems that have remained at the centre of attention for years. The use of various onomastic terms with different meanings by scholars is a major obstacle of proper understanding. Without clear understanding and standardization of terms onomasticians cannot exchange ideas, discuss concepts and advance knowledge, which negatively impacts the larger exchange of experience, international collaboration and the further development of onomastics.

As BotOLV HELLELAND pointed out (HARVALÍK-CAFFARELLI 2007: 196), at an early stage onomastic research was a national science the main goal of which was to collect and investigate written and oral name material, primarily place-names and personal names, and publish these with comments and explanations. The need for an international terminology was not felt very strongly. Over the years this has changed and today onomastic theoretical and methodological problems are discussed in various international contexts, for instance at international congresses. When publishing papers and volumes for international readers it is important that the terminology is understood. This applies to onomastics in general, but is especially important when dealing with theoretical problems. It is also advantageous to use terms that are understood internationally when defining onomastic categories.

The absence of homogeneity in onomastic terminology may give the impression that onomastics is not a well-developed discipline, which serves to undermine its credibility. However, the differences in the use and/or meaning of terms are mainly caused by differing theoretical approaches to onomastics and by the divergent traditions of onomastic schools, countries and languages. This means that inconsistencies - ambiguity and vagueness of terms - do not manifest themselves on a national level, in a certain language or within an onomastic school.

The foundations of a common terminology have been laid down in several monoand multilingual dictionaries of onomastic terminology and in terminological systems. The importance of onomastic terminology is also emphasised by the fact that even works primarily orientated either at general questions of onomastics or unique problems deal with it.

The major problems apparent in certain terminological systems are caused by the use of multiple terms for the same phenomenon or the use of the same term in different meanings in the terminology of various onomastic schools, and also by the the parallel existence of international and domestic terms.

It is understandable that the ambiguity and uncertainty of terms leads to confusion. Eventually, however, terms become both more precise and more stable but - unless this 
process is coordinated - this stabilisation is a long-term process with an uncertain outcome. Therefore, any terminology utilised should be the result of teamwork and cooperation or its binding enactment may be compromised. For this reason, at the $21^{\text {st }}$ International Congress of Onomastic Sciences in Uppsala in 2002, the establishment of a special onomastic commission under the auspice of the International Council of Onomastic Sciences (ICOS) was proposed, the goal of which would be to assemble an international guidebook to the onomastic terms in current use, together with their definitions (HARVALíK 2005). This terminological group that works under the ICOS Board of Directors was founded at the meeting of the ICOS Board held in Prague 2004 ( $26^{\text {th }}$ to $27^{\text {th }}$ March) and its members represent individual languages, countries or regions and onomastic schools.

The activities of the group have been thoroughly described in HARVALíK 2014; and summarized in this volume (BÖLCSKEI 2017, FARKAS 2017). The most important result of the group's work, a three-language version of a basic list of onomastic terms in the official languages of the ICOS (English, German, and French) was published on the ICOS website (Icosweb Terminology). One of its current tasks is to prepare new versions of the glossary in other languages, which will make it accessible to a broader circle of onomasticians. The Czech and Slovak versions have been completed, while others are under preparation. I acknowledge the publication of the Hungarian version - along with a supplementary Hungarian-English term index and a quadrilingual list presenting EnglishHungarian-German-French term equivalents - in this volume with great pleasure.

Another important work in the field of onomastic terminology is the Hungarian version of the United Nations Group of Experts on Geographical Names (UNGEGN) Glossary of Terms for the Standardization of Geographical Names, which is also part of this publication.

Not only as the President of the International Council of Onomastic Sciences and the Chair of the ICOS Terminology Group, but - above all - as an onomastician, I highly appreciate the work of my Hungarian colleagues that is presented in this volume. Their results prove that coordination between the terms used in different languages and onomastic schools - always taking into account their existing usage and respecting the right of pluralism - can substantially contribute to an improved understanding of the results of individual researchers in their study of proper names and thereby stimulate further development in the principles of the general theory of onomastics.

\section{Bibliography}

BölCSKEI, ANDREA 2017. The Hungarian Versions of Two International Onomastic Terminological Glossaries. In: BÖLCSKEI, ANDREA - FARKAS, TAMÁs - Slíz, MARIANN eds., Magyar és nemzetközi névtani terminológia / Hungarian and International Onomastic Terminology. Uppsala-Budapest: International Council of Onomastic Sciences - Magyar Nyelvtudományi Társaság. 85-98. https://doi.org/10.26546/5061110.10

FARKAS, TAMÁs 2017. Terminological Studies in International and Hungarian Onomastics. In: BöLCSKEI, ANDREA - FARKAS, TAMÁS - SLÍZ, MARIANN eds., Magyar és nemzetközi névtani terminológia / Hungarian and International Onomastic Terminology. Uppsala-Budapest: International Council of Onomastic Sciences - Magyar Nyelvtudományi Társaság. 65-84. https://doi.org/10.26546/ $\underline{5061110.9}$ 
HaRValík, Milan 2005. Towards a new millennium - towards a common onomastic terminology? In: Brylla, Eva - Wahlberg, Mats eds., Proceedings of the 21st International Congress of Onomastic Sciences. Uppsala 19-24 August 2002. Uppsala: Språk- och folkminnesinstitutet. 1: $160-171$.

HaRvalík, Milan 2014. Towards a common onomastic terminology? The next step. In: TORT I Donada, JoAn - Montagut i Montagut, Montserrat eds., Els noms en la vida quotidiana. Actes del XXIV Congrés Internacional d'ICOS sobre Ciències Onomàstiques. / Names in daily life. Proceedings of the XXIV ICOS International Congress of Onomastic Sciences. Biblioteca Tècnica De Política Lingüística 11. Barcelona: Generalitat de Catalunya. 21-25. http://www.gencat. cat/llengua/BTPL/ICOS2011/004.pdf \& https://doi.org/10.2436/15.8040.01.4

HARVALÍK, MiLAN - CAFFARELLI, ENZO 2007. Onomastic terminology: an international survey / Terminologia onomastica: un'inchiesta internazionale. Rivista Italiana di Onomastica 13: 181-220.

Icosweb Terminology = ICOS Lists of Key Onomastic Terms. https://icosweb.net/drupal/terminology

MILAN HARVALÍK President of the International Council of Onomastic Sciences 

BÖLCSKEI-FARKAS-SLÍz eds., Magyar és nemzetközi névtani terminológia. Hungarian and International Onomastic Terminology. Uppsala-Budapest: International Council of Onomastic Sciences - Magyar Nyelvtudományi Társaság, 2017. 23-24. DOI: $10.26546 / 5061110.5$

\section{Preface}

As the director of the Institute for Hungarian Language Strategy I welcome the readers of this volume. It is a pleasure and an honour that the volume has been finished for such an exceptional event as the $26^{\text {th }}$ International Congress of Onomastic Sciences, an event held in Hungary for the first time, at the University of Debrecen. The fact that this conference (which is organized every three years) will be held in Hungary this year can be seen as the acknowledgement of the outstanding work Hungarian researchers of onomastics complete in the international scientific sphere. It proves that Hungarian onomastic research is gaining ever more international insight and building newer connections.

The Institute for Hungarian Language Strategy (an office overseen by the Prime Minister's Office) was established by the Government on $4^{\text {th }}$ March 2014 with the purpose of being a consultant body of the Government in questions of language and language politics, and is tasked with drawing up a Hungarian language strategy for the whole Hungarian language community, holding the unity of the nation in sight. I find the coordination of the planned development of different terminologies, the comparative research of Hungarian terminology in Hungary and abroad, and the creation of dictionaries of comparative terminology a very important part and task of language strategy. Therefore, it was imperative to support the creation of the volume Magyar és nemzetközi névtani terminológia / Hungarian and International Onomastic Terminology, which was prepared in the cooperation of onomasticians affiliated with Eötvös Loránd University, Budapest and Károli Gáspár University of the Reformed Church in Hungary, Budapest.

Onomastics is one of the most dynamically developing fields of linguistics, and yet just as any other branch of science - this discipline centred around proper nouns has its own terminological problems. These problems (I hope) will be solved as soon as possible at the professional conferences focusing on the field.

The development of specialised languages and terminology is a field worthy of attention as its achievements are useful for laypersons as well: they provide an easier way of understanding, reduce the chances (and the feeling) of being at the mercy of bureaucracy, increase the confidence of individuals and the community, increase the effectiveness of self-determination, and make the functioning of society more cost-efficient.

The language of our nation is also a tool for identity, communication and cognition. Individuals and the community can only use the language efficiently if the required conditions are met. Such a condition is the existence of a clear, accurate, precise terminology which is coordinated and supervised by experts. It is essential that the so-created terminological databases prove to be extensively useful, that is - if possible - they should be freely accessible in the form of online dictionaries and/or public databases. According 
to UNESCO directives terminological planning, the future innovative development of specialised languages is a significant task.

The publication of the Hungarian versions of two international glossaries of onomastic terminology is a crucial step in this research field. These glossaries are included in the present volume and I hold them in high esteem from a strategical point of view. I find both the basic terminology of the field of onomastics (used primarily in the communication between experts) and the glossary of terminology used in geography, in cartography, in documentation and information technology, and in linguistics (linguistic terms used for the standardization of geographical names) to be cardinal, this is a publication that has been long awaited.

Although terminology planning exists within individual and institutional frames too, scientifically coordinated terminology politics and thinking is often not present. It is vital that a functioning institutional system oversees these activities. Such an institutional network may be supervised by Parliament or academic institutions, similarly to other countries. The Terminology Council of the Hungarian Language as a suborganization of UNESCO plays and advisory role in Hungary. Other important workshops of terminology are the Terminological Research Group of Károli Gáspár University of the Reformed Church in Hungary and the Termini Research Network. The latter is the collection of the linguistic research institutes of the Carpathian Basin and its researches are, among others, centred around questions of specialised languages and terminology.

The systematic development of specialised languages and terminologies and their harmonization with the terminologies of other languages is a grand, useful, long-desired undertaking. One that can only be completed through the collaboration of professionals and decision-makers. The papers presented in English, German, and French at the 26th International Congress of Onomastic Sciences, in addition, the work of experts dealing with onomastic terminology at the International Council of Onomastic Sciences provide excellent intellectual munition for this cause.

TÓTH ATTILA

Director of the Institute for Hungarian Language Strategy 
BÖLCSKEI-FARKAS-SLÍz eds., Magyar és nemzetközi névtani terminológia. Hungarian and International Onomastic Terminology. Uppsala-Budapest: International Council of Onomastic Sciences - Magyar Nyelvtudományi Társaság, 2017. 25-26. DOI: $10.26546 / 5061110.6$

\section{Editors' Foreword}

Adequate scientific terminology is in close and reciprocal relation to its subject. Uncertainties, inconsistencies in terminology make it difficult to overview and comprehend a field or topic; to provide answers, to give further thought to arising questions; to carry out scientific discussions, to adjust different research projects and to maximize practical applicability; i.e. to develop and exploit a branch of science, at both a national and international level. However, experience shows that pieces of specialized literature in different languages and cultures, in special languages or even in a given field display considerable differences in their adopted terminology. For these reasons, it is important to explore the differences, together with the concepts of the field under observation as a system and its characteristics. To ensure unambiguous professional communication, an attempt should be made to reach a consensus concerning the forms, meanings, logical connections, stocks and rules for the use of terms.

The theoretical and practical applications of onomastic knowledge are undoubtedly connected to several disciplines and professional fields. Linguistics, translation studies, literary studies, history, law, transport sciences, geography, cartography, library and information science, communication sciences, public administration sciences - to mention only the most obvious examples - are extensively affected by the problems posed by the different types or uses of proper names. Thus, the national and international standardization and harmonization of onomastic terminology, out of the disciplines of linguistics, should be considered necessary and timely.

In recent years, an increased interest in terminology in general, can be observed, not only in Hungary, but also on an international scale. This trend is also apparent in onomastics, the field of the current volume. Simultaneously, in Hungary, the noticeable lack of up-to-date terminological dictionaries and/or databases in the humanities and particularly in the field of linguistics is obvious. In several languages, comprehensive linguistic or onomastic terminological dictionaries of lesser or greater extent are available, while only more focused works can be reported from Hungary.

The most important achievements in the works of international onomastic terminology are two multilingual term lists. One of them is a glossary by the Terminology Group of the International Council of Onomastic Sciences (ICOS), a list of key onomastic terms in English, German, and French. The other is the glossary of terms used in the process of the standardization of geographical names, compiled by the United Nations Group of Experts on Geographical Names (UNGEGN).

The current volume presents the Hungarian versions of these two current international glossaries of onomastic terms, accompanied by relevant multilingual term indices. The glossaries and the indices were prepared in work projects, involving a few people. They 
are supplemented by two studies, published in Hungarian and English. The paper by TAMÁS FARKAS outlines the history, most important trends and fields as well as the results of international and Hungarian onomastic terminological works; while the article by ANDREA BÖLCSKEI discusses the history, contents and structure of the original as well as the Hungarian versions of the two glossaries, paying attention to the unique problems of their compilation.

This volume is the result of the activity of the Hungarian Subgroup of the ICOS Terminology Group, established after the 2011 ICOS Congress in Barcelona, in cooperation with the Hungarian research group in applied onomastics, its associate working group. Works were done at the Department of Hungarian Linguistics of Károli Gáspár University of the Reformed Church in Hungary and at the Department of Hungarian Historical Linguistics, Sociolinguistics and Dialectology of Eötvös Loránd University, Budapest. Professional credibility of the volume is ensured through the work of peerreviewers from several disciplines. The volume, from a terminological point of view, was reviewed by ÁGOTA FóRIS (Budapest); and, from the perspectives of international and Hungarian onomastics, was checked by MiLAN HARVALíK (Prague) and JÁN BAUKO (Nitra). The Hungarian version of the UNGEGN Glossary of Terms for the Standardization of Geographical Names was reviewed by numerous representatives of relevant professional fields. The book was jointly published by ICOS and the Society of Hungarian Linguistics.

In his Foreword to the volume, MILAN HARVALíK, the president of ICOS and the initiator and chair of the ICOS Terminology Group expresses his thoughts about the history and importance of international onomastic terminological works. ATTILA TóTH, the director of the Institute for Hungarian Language Strategy, the financial supporter of the publication of the volume, calls attention to the importance of the maintenance of terminology in national and special languages.

The editors of the book wish to express their thanks to all colleagues who contributed to this volume with their work. The work of the ICOS and UNGEGN experts who compiled and published the original term lists should also be duly recognised. The editors also thank the Institute for Hungarian Language Strategy for the financial support for the publication of this volume.

This bilingual volume will be available both in print and online as an open access publication. The editors aim to ensure the national-wide and international applicability of the term lists and the relevant information in several disciplines, facilitating successful communication among Hungarian and foreign onomasticians, the representatives of different professional fields dealing with proper names, and to strengthen professional relationships, encourage common research projects and help the further development of Hungarian and international scholarship. 
Tanulmányok 

BÖLCSKEI-FARKAS-SLíz szerk., Magyar és nemzetközi névtani terminológia. Hungarian and International Onomastic Terminology. International Council of Onomastic Sciences - Magyar Nyelvtudományi Társaság, Uppsala-Budapest, 2017. 29-47. DOI: $10.26546 / 5061110.7$

\section{Nemzetközi és magyar névtani terminológiai kutatások}

1. Bevezetés. E tanulmány az idegen nyelvü, nemzetközi, valamint a magyar névtani terminológia terén végzett eddigi munkálatokat, illetve eredményeket szándékozik főbb vonalaiban, vázlatosan bemutatni. Első része a nemzetközi névkutatással foglalkozik. Ennek során az idegen nyelvű névtani terminológiai szótárak, szójegyzékek palettájáról (2. pont), a terminológia kérdéskörének a külföldi onomasztikában való megjelenéséröl, illetve a névtani terminológiával foglalkozó fontosabb nemzetközi projektekről (3. pont) ad áttekintő képet. A tanulmány második, terjedelmesebb része a magyar névtani terminológia kérdéskörére fordítja a figyelmet. Sorra veszi az átfogó igényű rendszerezésére és leírására irányuló kezdeményezéseket (4. pont), valamint bemutatja a témakörnek a magyar szakirodalomban való megjelenését (5. pont). A tanulmány befejezéseképpen (6. pont) a nemzetközi és a nemzeti nyelvü (konkrétan: a magyar) névtani terminológia kapcsolatát, a vonatkozó munkálatok összefüggéseit, illetve főbb szempontjait vázolja fel az olvasó számára.

2. A nemzetközi névtani terminológiai irodalom. Különböző országok névkutatóinak munkájaként egy- és többnyelvü névtani terminológiai jegyzékek és szótárak egész sora készült el a 20. század második felétől napjainkig. Elsőként e terminológiai munkákról adok rövid áttekintést az alábbiakban.

2.1. A névtani terminológia módszeres feldolgozásában a német és a szláv nyelvü névkutatás bizonyult úttörő szerepünek. Az első ilyen munkák ugyanis az 1960-as években a német (WITKOWSKI 1964), majd egyes szláv nyelvek névtani terminológiájáról jelentek meg (ukrán: NIMCSUK 1966, szorb: PETR 1969, később majd orosz: PODOLSZKAJA $1978^{1}$ és $1988^{2}$ ). (A német és az orosz terminológiai szótár magyar ismertetéseit 1. FEHÉRTÓI 1966: 246-247, UDVARI 1981.) Nemzetközi szakmai együttmüködések révén, illetőleg ezeket is szolgálandó készültek el azután a német és egy tucatnyi szláv nyelv névtani terminusainak közös feldolgozásai (bővebben 1. BAUKO 2012: 157-158). Előbb a Základní soustava a terminologie slovanské onomastiky (német címén: Grundsystem und Terminologie der slawischen Onomastik) címü munka jelent meg 1973-ban (SVOBODA et al. 1973), amelyet pont egy évtizeddel később az Osnoven sistem i terminologija na slovenskata onomastika (más nyelvü címein: Osnovnaja sistema i terminologija slavjanskoj onomastiki. Grundsystem und Terminologie der slawischen Onomastik) címü összeállítás követett (BEZLAJ et al. 1983). A német névkutatás terminusairól azóta újabb összeállítás is született (WALTHER 1998), ahogyan több szláv nyelvéröl is. (Az ukránról, terminológiai szótárként, nyomtatásban: BUCSKO-TKACSOVA 2012; a lengyelről, terminológiai jegyzékként, elektronikus formában: GAŁKOWSKI 2012. A különböző szláv 
nyelvekre együttesen 1. még RZETELSKA-FELESZKO et al. red. 2002-2003. 2: 567-602. További szláv nyelvü névtani terminológiai jegyzékek munkálatai jelenleg, aktuálisan is folynak.)

Az észak-európai névkutatók ugyancsak elkészítették névtani terminológiájuk hasonló feldolgozásait (KIVINIEMI et al. 1974, SCHMIDT 1981). A nagyobb uráli nyelvek részéről - a magyar nyelv kivételével - szintén születtek ilyen jellegü összegzések (finn: a svéddel közösen, 1. KIVINIEMI et al. 1974; észt: HENNO-PÄLL 2003). (Az elöbbi munka magyar ismertetését 1. MIZSER 1979: 247-248.)

Készülttek terminológiai szótárak - egyaránt az észak-amerikai névkutatásnak köszönhetően - mind az angol nyelvü onomasztika (SMITH 1967, ROOM 1996), mind a (kanadai) francia nyelvű (hely)névkutatás (DORION-POIRIER 1975) terminusairól. Több nagy nyelv vonatkozásában ugyanakkor mindmáig hiányzik az említettekhez hasonló feldolgozás, mint például az olasz esetében (vö. GAŁKOWSKI 2010; 1. ugyanakkor FÁBIÁN 2001 kétnyelvü terminológiai jegyzékét, bővebben még később).

Külön emlitést érdemelnek az ENSZ Földrajzi Névi Szakértői Csoportjának (UNGEGN) munkatársai által elkészített speciális célú, valamint a Nemzetközi Névtudományi Társaság (ICOS) Terminológiai Munkacsoportja által összeállított átfogó igényü, kifejezetten nemzetközi felhasználásra szánt glosszáriumok. (Ezekről bővebben 1. még később.)

2.2. A korábban megjelent terminológiai jegyzékek, szótárak terminusai többé-kevésbé megszokottá, természetessé válhattak egy-egy nyelv névtani szakirodalmában. Ugyanakkor napjainkban is tapasztalható az a figyelem, amely a névkutatás terminológiájára és az ezzel összefüggő névelméleti problémakörökre irányul, s újabb terminológiai szójegyzékekre is mutatkozik igény és szándék. Megkezdődtek például a Szlovák Tudományos Akadémia kebelén belül múködő Névtani Bizottság irányításával - és nemzetközi közreműködéssel - egy szisztematikus elektronikus névtani terminológiai adatbázis összeállításának munkálatai. A készülő adatbázis az egyes terminusokat különböző információkkal (többek közt a más nyelvű - köztük a magyar nyelvi - megfelelőkkel) együtt szándékozik feldolgozni (1. BAUKO 2015b: 73). Az Osnoven sistem i terminologija na slovenskata onomastika címủ soknyelvủ (szláv és német) terminológiai szótár (BEZLAJ et al. 1983) újabb, bővített és átdolgozott kiadására már évekkel ezelőtt született javaslat (1. HARVALíK 2007).

A névtani terminológia problematikájára az újabb, összefoglaló jellegü és reprezentatív igényü külföldi, illetve nemzetközi névtani kézikönyvek gyakran külön figyelmet fordítanak. Akár módszeresen visszatérö kérdéskörként az egyes tematikus fejezetek bevezetéseként (pl. BRENDLER-BRENDLER Hrsg. 2004), akár önálló fejezetként (pl. WITKOWSKI 1995, KALETA 1998) - illetve e két módszert egyszerre alkalmazva (pl. MARCATO 2009: 10-13 és passim) -, akár pedig - az önálló fejezetek mellett - a mühöz csatolt terminológiai mutatók formájában (RZETELSKA-FELESZKO et al. red. 2002-2003. 1: 81-94, 2 : 567-602).

Az ICOS háromévente megszervezett nagyszabású nemzetközi névtani kongresszusain a névtani terminológia kérdésköre több alkalommal is (Pisa, 2005; Torontó, 2008; Barcelona, 2011) külön szekcióként jelent meg a programban, a téma fontosságát és a rá irányuló szakmai figyelmet egyaránt jelezve. Az ICOS-kongresszusok alkalmával ülésezik egyébként az ICOS terminológiai munkacsoportja is.

Konferencia-előadások, tanulmányok, folyóiratcikkek sora tárgyalja napjainkban a nemzeti és nemzetközi névtani terminológia általános, elméleti, metodológiai problémáit, 
illetve az egy-egy részterülettel, kérdéskörrel vagy akár egy-egy konkrét terminussal kapcsolatos specifikus kérdéseket. (A fontosabb továbbvezető irodalomhoz 1. pl. az ICOS terminológiai listáinak végén közölt válogatott bibliográfiákat a szervezet honlapján.)

3. A nemzetközi névkutatás terminológiai munkálatai. A különböző nyelvek kutatói, szakemberei közötti együttmüködések - különösen azok szervezettebb formái - természetszerüleg irányították rá a figyelmet a névtani terminológia, illetve a terminológiai harmonizáció kérdéseire. Mindezt gyakorlati lépések, szerveződések és munkálatok sora kísérte nemzetközi színtéren.

3.1. Az 1959-ben megrendezett első nemzetközi szláv névtudományi kongresszus nyomán alakult meg a Nemzetközi Szlavisztikai Komité Onomasztikai Bizottsága, s az ennek kebelén belül létrejött négy albizottság egyike a Terminológiai Albizottság lett (vö. WITKOWSKI 1995: 290). Ennek és a Német Tudományos Akadémia Szlavisztikai Intézetének az együttműködésével készült el az onomasztika fentebb említett első terminológiai szótári feldolgozása (WITKOWSKI 1964), mintegy hatszáz névtani terminussal. A testület a későbbi terminológiai munkálatokból is kivette a részét. (A szláv, különösen a csehszlovák, illetve a szlovák névkutatás terminológiai munkálatairól 1. még BAUKO 2012: 157-159.)

Az észak-európai országok névtudományi együttmüködését biztosító NORNA (alapítva 1971-ben) egyébként hasonlóan jó példával szolgált a névtani terminológia fontosságára. A NORNA által szervezett legelső szimpózium központi témáját a névtani terminológia problematikája képezte, amely a későbbi szimpóziumok során is fel-felbukkant a programban (GYÖRFFY 2007: 250).

3.2. Az ENSZ 1959-ben (akkor még más néven) felállított Földrajzi Névi Szakértői Csoportjának (United Nations Group of Experts on Geographical Names, UNGEGN) köszönhetően elöször 1984-ben, majd újabb, javított kiadásban 1987-ben jelent meg egy terminusgyüjtemény, mely a földrajzi nevek egységesítésében használt szakkifejezéseket adta közre. A kiadvány eredetileg az ENSZ hat hivatalos nyelvén látott napvilágot. (A második kiadás később magyar fordításban is megjelent: FöLDI 1992.) Az elkészült munka hiányosságainak kijavítására azonban már 1989-ben kezdeményezték egy terminológiai munkacsoport felállítását. A NAFTALI KADMON irányításával készült és szerkesztett, a napjaink helynév-standardizációs tevékenységéhez kapcsolódó terminológiát közreadó és értelmező újabb összeállítás közel négyszáz tételből áll, s ugyancsak a világszervezet hat hivatalos nyelvén jelent meg, 2002-ben (Glossary of Terms for the Standarization of Geographical Names). Ehhez azóta egy kisebb kiegészítéseket és javításokat tartalmazó Addendumot is kapcsoltak, s anyaga további nyelveken is megjelent. A szójegyzék folyamatos korszerüsítése, gondozása a munkacsoportnak továbbra is feladata. (Minderről bővebben, továbbvezető irodalommal 1. BÖLCSKEI 2017, kötetünkben. A hivatkozott alapdokumentumok elérhetők az UNGEGN honlapján.)

A földrajzi nevek nemzetközi standardizációja több nemzetközi szervezetet érintő tevékenység, melynek szükségképpen vannak terminológiai vonatkozásai. Erre ad példát a tengerfenék-domborzati nevek egységesítésének kérdésköre is. Az ehhez kapcsolódó irányelveket és útmutatót tartalmazó alapdokumentum a Nemzetközi Hidrográfiai Hivatal (International Hydrographic Bureau, IHB) kiadásában, több változatban és nyelven 
megjelent már. Angol-magyar nyelvű verziója, mely a megfelelő kétnyelvű terminológiai jegyzéket is tartalmazza (MÁRTON-DUTKÓ szerk. 2003: 17-30, újraközlését 1. MÁRTON 2012: 305-318), szintén rendelkezésre áll. Ennek a munkának is voltak hazai, a magyarországi Földrajzinév-bizottság müködéséhez kapcsolódó előzményei (FöLDI 1979, újraközléseit 1. MÁRTON 1992: 91-92, ill. 2012: 278-279; a témakör tudománytörténetéröl bővebben 1. MÁRTON 2012: 184-192).

3.3. A Nemzetközi Névtudományi Társaság, azaz az ICOS (International Council of Onomastic Sciences) keretei közt, a 2002-es uppsalai nemzetközi névtudományi kongresszuson MILAN HARVALÍK egy terminológiai munkacsoport létrehozását indítványozta (1. HARVALÍK 2005). A munkacsoport 2004-ben meg is kezdte müködését, melynek köszönhetően különböző nyelvek és névtani iskolák képviselőinek közremüködésével elkészült az alapvető terminusok - rövid meghatározásokkal és példákkal ellátott - listája. Ezt az ICOS három hivatalos nyelvén: angolul (ez volt a munkanyelv is), valamint németül és franciául tették közzé. E listák kiinduló változatát a 2005. évi ICOS-kongresszuson, Pisában, majd bővebb változatában 2011-ben, a barcelonai ICOS-kongresszuson mutatták be. A jegyzékek jelenlegi formájukban mintegy 70 terminus leírását tartalmazzák (Lists of Key Onomastic Terms). Ezek a terminológiai szójegyzékek elérhetők az ICOS honlapján. (Minderről bővebben 1. HARVALÍK 2014: 21-22, ill. BÖLCSKEI 2017, kötetünkben.)

Az ICOS a névkutatók tágabb körét igyekezett bevonni terminológiai munkacsoportjának tevékenységébe. Müködésének kezdetén például több, különböző országokból származó névkutatót megkerestek egy rövid, a terület általános problematikájára vonatkozó kérdéssorral, s a válaszokat és azok összegzett tanulságait közzé is tették (HARVALÍKCAFFARELLI 2007, magyar válaszadójuk FÁBIÁN ZSUZSANNA volt). Ebből a felmérésből is kiviláglott, hogy a névtani terminológia terén minden nyelvben egy sor - részben hasonló, részben eltérő - probléma, illetve feladat áll a kutatók előtt. Ezért az ICOS terminológiai munkacsoportja a fent említett terminológiai jegyzékek elkészítését követően további munkaterületekkel, illetve csoportokkal bővítette tevékenységét. Ezek célja egyrészt további nyelvek (és egyúttal kultúrkörök) számára is hozzáférhetővé tenni, illetve adaptálni az elkészült terminológiai jegyzékeket - mely munkába immár magyar kutatók is bekapcsolódtak -, másrészt pedig az egyes névtudományi részterületek terminológiáját módszeresen és részletesebben is feldolgozni.

3.4. Az ICOS és az UNGEGN névtani terminológiával foglalkozó képviselői a 2008. évi torontói ICOS-kongresszuson tartott egyeztető megbeszélés nyomán egy közös terminológiai munkabizottságot is létrehoztak. A két testület készítette terminológiai jegyzékek közt különböző típusú, részben szükségszerü, részben viszont csökkenthető különbségek találhatók. (Minderről bővebben 1. NYSTRÖM 2014, vö. VASILEVA 2014 is.) A két szervezet összehangoltabb munkája - melyet személyi átfedések is elősegítenek - természetszerüleg csak nyereséggel járhat az érintett szakterületek számára.

3.5. Az UNGEGN, illetve az ICOS itt említett névtani terminológiai jegyzékeinek további nyelveken való kiadására egyelöre néhány példát ismerünk csupán. Magyar változatuk e tanulmánnyal együtt jelenik meg, nyomtatott és elektronikus formában. 
4. Törekvések a magyar névtani terminológia átfogó igényű rendszerezésére és leírására. A magyar névtudomány terminológiájának, illetve egyes terminusainak a problematikáját alkalmilag, illetve érintőlegesen többen is tárgyalták már. E szakterület müszóhasználatának kérdésköréről azonban csak a hetvenes években, a magyar névtudomány dinamikus szerveződésének időszakában bontakozott ki tágabb körü, átfogó igényü eszmecsere. A kezdeményező szerep - mint oly sok más területen is - HAJDÚ MIHÁLYé, a magyar névkutatás későbbi első számú szervező egyéniségéé volt. (L. a leginkább illetékes visszaemlékezéseit is: HAJDÚ 2010: 24-26.)

4.1. Vitaindító a névtudomány műszavairól címmel 1974-ben készült el és lett szétküldve - stencilezett kiadványként - az ún. Bokor Levelek 12. száma (HAJDÚ 1974a; kisebb változtatásokkal később a Névtani Értesítőben is: HAJDÚ 1979). Anyagát az ifjabb nyelvész generációk egykori szakmai-baráti körének, a Bokornak az egyik összejövetelén vitatták meg, míg többen írásbeli hozzászólásaikat juttatták el a kezdeményezőhöz. A javaslatok nyomán egy tartalmilag és formailag egyaránt jócskán átdolgozott, konkretizált változat (HAJDÚ 1974b) készült az anyagból. (Erre azért is szükség volt, mert az eredeti szöveg ténylegesen vitaindító formájában lett megfogalmazva.) Az újabb anyagot azután az eredeti szándéknak megfelelően a Magyar Tudományos Akadémia - akkor még létező - névtudományi munkabizottságához terjesztették fel.

Az említett elöterjesztésben megfogalmazott elvek a következők voltak: bizonyos fokú egységesítés (a stilisztikai vagy célszerüségi szempontú szinonimitás lehetséges megtartásával); a már konvencionalizálódott műszavak megtartása (szemben az elméleti nézőpontból indokoltnak látszó újításokkal); a jobban használható (rövidebb, kifejezőbb, jobban képezhető) terminusok preferálása. A tervezet az alapvető szempontok megfogalmazását követően mintegy kéttucatnyi szinonimapárt, illetve szinonimasort vett számba, a köztük lévő választásra téve vagy kérve javaslatot. A további kérdéseket - mint nem csupán terminológiai problémákat - az előterjesztő ,elvi cikkek sorozata” után látta megoldhatónak.

Az előterjesztés végezetül, a témához kapcsolódóan egy, a névkutatás müszavait is számba vevő kiadvány - MEZÖ ANDRÁs javaslata nyomán immár egy névtani lexikon tervét ismertette röviden. A javasolt névtani lexikon elkészítésének az elvei a következők lettek volna: minden egykor előfordult müszó vagy körülírás felvétele; szükségesnek tünő új müszavak alkotása; szinonimák (esetleg kerülendőnek tartott kifejezések) felvétele a preferált megnevezésre utalóan; egyes kifejezéseknek akár egy nagyobb szócikk részeként való tárgyalása. Az addig összegyüjtött címszavak száma közel ötezer volt, a tervezett munka pedig nagyságrendileg 3-4 ezer önálló szócikkből állt volna. Amint azt a mutatványként eredetileg mellékelt címszólista is jelezte, HAJDÚ és MEZŐ javaslata valóban inkább enciklopédikus jellegü, mint szótárszerü feldolgozásra irányult. HAJDÚ egyik visszaemlékezésében a ragadványnevek témaköréhez (és betürendjéhez) kapcsolódó tervezett címszavakat idézi is e tervezetből (HAJDÚ 2010: 25; a fogalomkör terminusaira egyébként 1. BAUKO 2009: 7-9). A konkrét müszavak mellett e mutatványban is egy sor lexikonszerű címszó kapott helyet, s nemcsak utaló, de önálló szócikként is (pl. ragadványnevek keletkezési inditékai, ragadványnevek nyelvi eszközei, ruházatra utaló ragadványnevek $\mathrm{stb}$.).

Az akadémiai munkabizottság a nagy tekintélynek örvendő Bárczi Géza vezetésével a következő évben megtárgyalta és támogatandónak találta a kezdeményezést. Nem sokkal 
később azonban Bárczi elhunyt, s az akadémiai átszervezések kapcsán maga a bizottság is megszüntette müködését. A kérdés így egy időre lekerült a napirendröl.

4.2. A problémakör újabb felvetését a magyar névkutatás folyóiratának, a Névtani Értesítőnek a néhány évvel későbbi megindulása tette egyrészt lehetővé, másrészt indokolttá. Az 1979-ben megindult periodika szerkesztője, HAJDÚ MIHÁLY egy rövid bevezetővel, kisebb változtatásokkal adta közre az eredeti vitaindítót a folyóirat hasábjain (HAJDÚ 1979). A témához kapcsolódóan több, különböző generációhoz tartozó névtanos kolléga: RÁCZ ENDRE, BACHÁT LÁSZlÓ, SZABÓ T. ATTILA, illetve ÖRDÖG FERENC és MÉSZÁROSNÉ VARGA MÁRIA, valamint a vitaindító HAJDÚ MIHÁLY hozzászólása is megjelent a folyóirat első számaiban (Névtani Értesítő 1979. 2: 28-34, 1980. 3: 56-60). Egyes terminusok kérdéséhez a folyóirat első évfolyamait recenzeáló KÁLMÁN BÉLA is hozzáfüzte megjegyzéseit (KÁLMÁN 1982: 502-503). Ekkoriban már több külföldi névtani terminológiai szótár hazai recenziója is olvasható volt Magyarországon (a német, finn-svéd, orosz munkáké: FEHÉRTÓI 1966, MIZSER 1979, UDVARI 1981).

$\mathrm{Az}$ ígéretes módon újraindult eszmecsere azonban ismét megszakadt. Más, nagyszabású hazai nyelvtudományi tervmunkák időszakában ez a téma tényleges támogatást nem kapott, kezdeményezőit pedig egyéb szakmai feladatok kötötték le. Mindemellett, úgy tünik, a névtani terminológia rendszerezésének, egységesítésének gondolata az akkori magyarországi névkutatókat sem érintette meg kellő mértékben. (Mindehhez 1. HAJDÚ 2010: 26, vö. HOFFMANN 2003: 54.)

4.3. A következő figyelemre méltó - s több szempontból újszerü - kísérlet bő két évtizeddel később, a 2000-es évek legelején történt a magyar névtani terminológia számbavételére. A VÁRNAI JUDIT SzILVIA nevéhez füződő, gyakorlatias megközelítésű angolmagyar névtani glosszárium egy nagyobb - több nyelvészeti területre kiterjedő - munka része, kezdeti lépése lett volna (VÁRNAI szerk. é. n.). Az interneten közzétett kétnyelvü, kísérleti célúnak szánt, 172 tételből álló puszta szójegyzék egy akkor indult kiadványsorozat fordítói munkálataihoz kapcsolódott: az Onomastica Uralica címü, angol és orosz nyelven megjelenő, magyarországi hátterü névtani periodika aktuális kötetének (2. History of the Study of Toponyms in the Uralian Languages. Debrecen, 2002) elkészítéséhez. (Ez a konkrétum magyarázhatja tematikus kiegyensúlyozatlanságát, ti. a helynévkutatás terminusainak felülreprezentáltságát is a listában.)

$\mathrm{Az}$ interneten ma is elérhető kétnyelvü glosszárium előszava szerint az itt közzé nem tett részek további járulékos információkat tartalmaztak (szükség esetén tömör definíciót, megjegyzést, szakirodalmi hivatkozást, esetleges rövidítést, szófaji besorolást, kereszthivatkozásokat). Az előszó emellett folyamatban lévő és folytatólagos munkálatokról adott hírt. A projekt azonban sajnos félbeszakadt, a tervezett nagyobb munka nem készült el, s háttéranyagainak sorsáról sincs tudomásunk. (VÁRNAI későbbi, névelméleti kérdéskörökkel foglalkozó doktori disszertációjában nem is érinti a névtani terminológia akár elméleti, akár gyakorlati, akár tudománytörténeti kérdéseit; vö. VÁRNAI 2005.)

Időrendi és tematikai szempontból egyaránt itt kell említést tennünk egy nyomtatásban megjelent, olasz-magyar névtani terminológiai glosszárium elkészültéröl is (FÁBIÁN 2001). Anyagában a címszóként szereplö, fontosabb olasz névtani terminusok olasz nyelvü értelmezéssel, magyar megfelelővel és/vagy értelmezéssel, valamint különböző nyelvü névtani példákkal szerepelnek. Az összeállítás egy magyarországi olasz szakos egyetemi 
hallgatóknak készült, az olasz névkutatás különböző területeiről bőséges válogatást adó tanulmánygyüjtemény részeként - egyfajta függelékeként - jelent meg.

Az itt említett kétnyelvü, magyar párú névtani terminológiai jegyzékeket az összeállítóik egyaránt az idegen nyelvi szakkifejezések szerint rendezve - azaz az idegen nyelvről a magyarra való fordítás, értelmezés iránya szerint - tették közzé. Magyar terminusok szerint rendezett változatuk, illetve magyar terminusmutató nem jelent meg mellettük.

4.4. Egy magyar névtani terminológiai szótár elkészítésére, ennek egyes szempontjaira, illetve lehetőségeire alkalmilag mások is tettek javaslatot a későbbiekben. A következő évek magyar névtani konferenciáin egy-egy névtani terminológiai vonatkozású előadás is hasonló felvetésekkel élt, lényegében a konkrétan tárgyalt problematikából levont konzekvenciaként (JUHÁsz 2004: 165-166, FARKAS 2008: 339-340). E felvetéseket tényleges elhatározás és konkrét lépések ugyanakkor nem követték. A magyar névtani terminológia módszeresebb vizsgálatának így néhány névkutató (Bölcskei Andrea, Slíz Mariann és, Farkas Tamás) összefogása adhatott újabb lendületet: az ICOS terminológiai munkabizottságának magyar alcsoportját megalkotva egyúttal a két legfontosabb nemzetközi névtani terminológiai jegyzék magyar változatának elkészítésére is vállalkoztak. A magyar névtani terminológiával való módszeres foglalkozás szándékát tehát az aktuális nemzetközi névtani terminológiai munkálatok, illetve a magyar és a nemzetközi névtani terminológia közti harmonizáció igénye is erőteljesen inspirálták.

Az alapvetően informális jellegü, de tervezett kutatói együttmüködés alapján, illetve ahhoz is kapcsolódóan 2010 után több irányban történtek lépések. Áttekintés készült a nemzetközi és a magyar névtani terminológiai munkálatok tudománytörténetéröl és aktuális állásáról (FARKAS 2011). Egy Névtan és terminológia címmel, úttörő jelleggel megrendezett workshop a témakör több alapvető kérdéskörét vitatta meg, előadások és egy kerekasztal-beszélgetés formájában (vö. BÖLCSKEI-FÓRIS 2012); az elhangzott előadásokat a Névtani Értesítő 2012. évi kötete tette közzé (HOFFMANN 2012, FARKAS 2012, SLÍZ 2012, BÖLCSKEI 2012, BAUKO 2012). Az elmúlt években módszeresebb figyelemben részesült továbbá a magyar névtani terminológia több általános jellegü, illetve tematikus kérdésköre, akár e kifejezetten terminológiai érdekü munkálatokhoz kapcsolódóan, akár a magyar névkutatás egyéb témaköreiben végzett feldolgozó munka eredményeként. (A módszeresebben vizsgált kérdéskörökről 1. a későbbiekben.)

Az említett kutatói együttmüködéshez kapcsolódóan kezdődtek meg az UNGEGN nemzetközi helynév-standardizációs terminusjegyzéke magyar változatának munkálatai (vö. BÖLCSKEI 2013a), majd pedig - ugyancsak BöLCSKEI ANDREA irányításával - az ICOS nemzetközi névtani glosszáriumát érintő hasonló munkák. (Mindkét projektről részletesebben 1. BÖLCSKEI 2017, kötetünkben.) Tervezet született egy átfogó igényü, korszerü magyar névtani terminológiai szótárra, annak elkészítési folyamatára és fö jellemzőire vonatkozóan is (FARKAS 2013). Az ezen munkálatoknak keretet adó, illetve a hátteret biztosítani hivatott kutatási pályázat azonban sajnos nem részesült támogatásban. A megkezdett munkák viszont folytatódtak, s míg az önálló magyar névtani terminológiai szótár megvalósítása továbbra is távlati cél maradt, az említett nemzetközi névtani terminológiai jegyzékek magyar változatai már a névkutatók rendelkezésére állnak. A két névtani terminológiai glosszáriumot és a kapcsolódó tanulmányokat - köztük ezt az írást is - közreadó kétnyelvü kötet szintén az említett kutatói együttmüködés keretében készült el. 
4.5. A magyar névkutatás fejlődését segítő kézikönyvek köréből (vö. HoFFMANN 2002: 16-17; bár az itt jelzett hiányok azóta egyébként csökkentek) továbbra is hiányolnunk kell egy átfogó igényü, részletes és módszeres magyar névtani terminológiai szótárat. Ezzel kapcsolatban hadd idézzem itt csupán az utóbbi évtizedek magyar névtudománya két iskolateremtő személyiségének véleményét. HAJDÚ MIHÁLY megítélése szerint „,[k]orunk egyik legégetőbb kérdése a névtani terminológia egységesítése" (HAJDÚ 2011: 345). S bár HAJDÚ megfogalmazását joggal árnyalhatnánk, az bizonyosnak látszik, hogy - immár HOFFMANN ISTVÁNt idézve - „[e]gy ilyen munka még akkor is elősegíthetné a tudományterület átláthatóbbá tételét és talán e tekintetben való némi egységesülését is, ha összeállítói inkább tájékoztató, semmint normaadó szándékkal gyüjtenék egybe a névtani szakirodalomban használatos fogalmak jelölöit" (HOFFMANN 2003: 55). Ezek a megállapítások összhangban is állnak a szóban forgó munka elkészítésére vonatkozó újabb (fentebb már hivatkozott) elképzelésekkel.

Egy magyar nyelvü - ugyanakkor a nemzetközi névtani terminológiára is tekintettel lévő - névtani terminológiai szótár elkészítését így továbbra is a magyar névkutatás előtt álló feladatnak tekinthetjük. Egy ilyen szakmunka hasznosnak bizonyulhatna nemcsak a hazai és a nemzetközi névtudomány, hanem más, kapcsolódó tudományterületek szempontjából, valamint a mindezek közötti szakmai kommunikáció, illetve együttműködések megkönnyítésében is (vö. FARKAS 2013: 445).

5. A névtani terminológia problematikája a magyar szakirodalomban. Az alábbiakban egyrészt a névtani terminológia általános helyzetével, kérdéseivel foglalkozó magyar szakirodalomról igyekszem átfogó képet adni, másrészt az egyes névtani részterületekhez, témakörökhöz kapcsolódó szakirodalomról - immár szükségszerüen csupán vázlatosabb - áttekintést nyújtani.

5.1. A névtani terminológia általános - azaz nem egy-egy konkrét névtudományi kérdéskörre vonatkozó - problémáiról viszonylag kevés tanulmány született mindeddig a magyar névtani szakirodalomban. Ide sorolhatók egyrészt a magyar névtani terminológia átfogó, rendszerező igényü leírására irányuló, azt szorgalmazó munkák (ezekről bővebben 1. a korábbiakban). Ide tartoznak másrészt azok a tanulmányok, amelyek elméleti igénnyel vizsgálják e terminológia jellemző sajátságait, rendszerint kiemelt figyelmet fordítanak annak problematikus vonásaira, példáikat pedig általában a névtan különbözö területeiről választják. Ilyen írások föleg az utóbbi néhány évben születtek, a következő témakörökre, aspektusokra fordítva figyelmüket: mi számít terminusnak (SLíz 2012); elmélet és terminológia összefüggései a terminushasználat és terminusalkotás szempontjából (HOFFMANN 2012); a terminusok létrejöttének okai, a terminushasználat változását befolyásoló tényezők, e változások következményei (SLÍz 2012); terminológiai hiányok (FARKAS 2012, SLÍz 2014); jelentéstani viszonyok, értelmezési problémák általában és a terminushasználat különböző színterein (FARKAS 2012, SLÍZ 2014); a nemzetközi hátterü és a magyar nyelvi eredetü terminusok problémái (FARKAS 2012, SLÍz 2014); a terminológiai egységesítés és harmonizáció kérdései (BÖLCSKEI 2012, 2017); a magyar és más nyelvek névtani terminológiájának módszeresebb összevetése (BAUKO 2012, SLÍZ 2014).

A névtani terminológia kérdésköre némi célzott figyelmet kapott egy tudománytörténeti összefoglaló munkában (HOFFMANN 2003: 53-55), illetve a magyar névkutatás közelmúltját és jelenét áttekintő és értékelő kötet keretein belül is (SLÍZ 2015: 101-103). 
A terminológiai problémák legtipikusabban azonban egy-egy aktuálisan tárgyalt részterület, témakör, valamely konkrétan vizsgált névtani kérdés kapcsán bukkannak fel a szakirodalomban. Az egyes összefoglaló munkák, adott témáról készült monográfiák, áttekintő igényü vagy éppen nagyon is speciális témájú tanulmányok gyakran nem is kerülhetnék ki, hogy foglalkozzanak a kapcsolódó terminológia kérdéseivel.

5.2. A következőkben a magyar névtani szakirodalomban legjellemzőbbnek tünő témaköröket és terminológiai vitatémákat igyekszem bemutatni, a névtan egyes részterületei szerinti áttekintésben. Részletes, módszeres és teljes körü feldolgozásra természetesen itt nem vállalkozhatom, ezért hivatkozásaimban is elsősorban az utóbbi évek vonatkozó munkáira fogok utalni. Ezek ugyanakkor továbbvezető irodalomként szolgálnak a korábbi vonatkozó szakmunkákhoz is.

5.2.1. A magyar névkutatás (újbóli) fellendülésének, illetve a tudományterület önállósodásának a jeleként az 1950-es évek második felében némi figyelmet vívott ki magának a szóban forgó diszciplína, azaz az onomasztika magyar megnevezésének kérdése (PAPP 1955: 258, MIKESY 1960, BENKÖ 1960). A felmerült kérdéseket ezúttal is az idő oldotta meg: a szakterület egyes lehetséges megnevezései nem tudtak meggyökeresedni, illetve idővel kiszorultak a használatból. Több megnevezése azonban ma is használatos, szinonimákként (névtan, névkutatás, névtudomány, illetve onomasztika) a tudományos használatban (HOFFMANN 2012: 127-128).

5.2.2. A helynevek témaköréhez kapcsolódik a magyar névkutatás egyik legtöbbször - és hosszú időn át, vissza-visszatérő módon, különböző érvek és ellenérvek alapján vitatott terminológiai kérdése: a helynév vagy földrajzi név problémája. Mindkét terminus ma is aktív használatban van, a közülük való választást inkább egyéni, s részben tudományterület szerinti preferenciák jellemzik. (Minderről részletesebben 1. HoFFMANN 2003: 53-55, 2012: 128-130.) Magának a helynévkutatásnak a megnevezése alig bizonyult kérdésesnek, és a helynévtan egyéb terminusainak a témaköre is - a szükségszerüen meglévő változatosság, illetve az elméleti megközelítések eltérései mellett - általában kevésbé tünt problematikusnak (áttekintően 1. HoFFMANN 2012: 130-132).

Meghatározó terminológiai újításokat hozott magával viszont - szükségszerüen - egy új (hely)névrendszertani leírási modell (HoFFMANN 1993, 1999), mely az erre épülő további szakirodalom révén részleteiben is gazdagodott még (1. HoFFMANN 2012: 133-135). Fontos utalnunk továbbá arra, hogy mivel a HOFFMANN-féle névrendszertani modell más névfajták leírására is jól alkalmazhatónak, illetve adaptálhatónak bizonyult (vö. HOFFMANN $2007^{2}$ : 7-8), a vele együtt bevezetett terminológia a magyar névkutatás más területein is ismertté és használatossá vált.

Külön sajátos témakörként kell utalnunk a nemzetközi helynév-standardizáció magyar terminológiájára, melyröl a fentebbi, nemzetközi vonatkozású részben már részletesebben esett szó (áttekintően 1. még BÖLCSKEI 2017, kötetünkben). E tevékenységgel kapcsolatban a különböző nyelvekbeli terminusok harmonizációjának kérdése, a hiányzó terminusok bevezetése, a meglévő terminusok pontos definiálása játssza a meghatározó szerepet. (Magának a helynév-standardizációs tevékenységnek a megnevezésére szolgáló terminusokat egyébként 1. BöLCSKEI 2012: 176.) Mint tudjuk, akár egyetlen terminus értelmezése is számos elvi és gyakorlati problémát vethet fel; erre szolgáltat különösen 
szemléletes példát a nemzetközi helynév-standardizáció témaköréből az exonima problematikája (vö. pl. POKOLY 2013, POKOLY-BÖLCSKEI-MIKESY 2015). A nemzeti nyelven értelmezhető standard név(változat) fogalma természetesen további terminológiai kérdésekkel függ össze (vö. GYŐRFFY 2012).

5.2.3. A személynevek témakörében elsősorban az egyes személynévfajták megnevezése bizonyult problematikusnak. Már csak azért is, mert az itt különösen jellemző, a mindennapi tapasztalatból, illetve a köznyelvből származó alapvető terminusok szakmai szempontból gyakran vitathatók, mégpedig áttetsző közszói jelentésük, a bennük kódolt szemléletmód, valamint a megnevezendő névfajták időbeli, illetve a nyelvi-kulturális kontextus szerinti változatossága miatt. A magyar és más nyelvek közti viszonylatban például konkrétan a családnév + keresztnév névsorrend eltérése is speciális terminológiai problémák forrása. A magyar nyelvi eredetű terminusok igen gazdag, névelméleti és névtörténeti hátterü lehetséges nehézségeit e témakör különösen jól példázza (FARKAS 2012: 142-144).

Az itt felmerülő problémákat azok a névtani feldolgozások jelezték, illetve mutatták be a legvilágosabban, amelyek a teljes (személy)névrendszert kívánták módszeresen és következetesen áttekinteni (vö. HoFFMANN 2008: 5-8). J. SOLTÉSZ KATALIN fontos névelméleti monográfiájában (1979) több terminológiai újítással próbálkozott, kevéssé eredményesen (értékelésükre 1. HAJDÚ 1981: 109-110 is). Az újításokra egyébként mindig nyitott HAJDÚ MIHÁLY összefoglaló munkájában (2003) viszont elsősorban az ismert terminusok áttekintésével, mérlegelésével és a köztük való választással igyekezett megoldani a problémát (HAJDÚ 2003: 151-153, 347, 638, 732; nem véletlenül emeli ki és részletezi terminológiai módszerességét egyik recenzense is: B. GERGELY 2007: 253-255). A használatban lévő terminológia áttekintése és értékelése akár interdiszciplináris vonatkozásai miatt is fontos és releváns feladatnak bizonyulhat (1. pl. egy készülő személynévjogi kötet kapcsán; SLíz megj. e.). Ugyanakkor a személynévrendszerek olyan újszerü elméleti áttekintése, mint amit HOFFMANN IsTVÁNnál olvashatunk (2008), szükségszerűen új terminusokat igényelt és vezetett be a magyar személykutatás terminológiájába (bár eredetileg nem a határozott terminusalkotás, hanem a lehetőségek felvetésének igényével; 1. HOFFMANN 2008: 10, 1. lábjegyzet). A személynévtípusok rendszerének, alá- és fölérendeltségi viszonyainak további átgondolása ugyanígy újabb megoldandó terminológiai kérdésekhez vezethet el (vö. SZENTGYÖRGYI 2016).

A magyar személynévtani terminológia tisztázása aktuális kérdésnek számít a többek által és sokat vizsgált történeti személynévtípusok esetében (részletesen 1. SLíz 2010), de az alig kutatott személynévfajták, így a J. SOLTÉSZ KATALIN - egyébként erősen vitatható terminusával helyettesitő nevek-ként megnevezhető névfajták vonatkozásában is (J. SOLTÉSZ 1979: 59; ezekhez 1. még HAJDÚ 2006). Az újonnan létrejött személynévtípus, az internetes azonosítónevek (nicknevek) kategóriája pedig nyilvánvalóan új terminus(ok) használatba vételét igényelte (bővebben 1. RAÁTZ 1999: 263, 2008: 444; vö. HAJDÚ 2006 is).

A személynévtani terminológia az egyes névfajták megnevezése mellett természetesen egyéb témaköröket is érint. Egy konkrét kutatási projekthez kapcsolódóan például a személynév-, illetve a családnév-változtatások kérdésköre is kiemelt figyelemben részesült. Egyrészt a kapcsolódó (és meglepően gazdag) történeti és jelenkori, köznyelvi és szaknyelvi szóhasználat elemzése révén (FARKAS 2008), másrészt a (személy)névváltoz(tat)ások tipológiájának a javasolt terminológiai innovációkkal történő leírásának 
köszönhetően (HAJDÚ 2009, VÖRÖS 2009). E témakör egy általánosabb névrendszertani leírási keretbe illesztve viszont ismét más - azonban korábbi munkákból jórészt már ismert (vö. HOFFMANN 1993, 1999, ill. TÓTH V. 2008, N. FODOR 2010: 115-120) - terminusokkal válhatott leírhatóvá (vö. FARKAS 2015b).

5.2.4. A helynevek és a személynevek mellett az egyéb névtípusok (valamint a határterületek) vizsgálata nagyságrendekkel kisebb figyelmet kap a magyar névkutatásban. Az elméleti kidolgozatlanságot olykor a terminológiai hiányok is jelzik; például az, hogy az ide tartozó névtípusokat, illetve azok többségét összefoglalóan megnevező terminus (szemben a nemzetközi szakirodalomban bevett krematonima megnevezéssel; FARKAS 2012: 145) nem áll rendelkezésünkre. A terminológiai innováció, illetve rendezés elsősorban az adott névtani témakörre vonatkozó rendszerszerű kutatások elmélyítésétől várható (1. pl. az épület-, építmény- és létesítménynevek témakörének példáján: HÁRI 2010).

$\mathrm{Az}$ irodalmi névtan területén ugyanakkor élénk és termékeny terminológiai gondolkodásról adhatunk számot újabban. E téren KOVALOVSZKY MIKLÓS 1934-ben megjelent, Az irodalmi névadás címü klasszikus munkája sokáig erőteljesen befolyásolta a szakmai szóhasználatot. Az irói, illetve az irodalmi névadás fogalomkörének tisztázása így több mint fél évszázaddal ezelött és napjainkban is egyaránt aktuális feladatnak tünhetett (MIKESY 1959, ill. KorOMPAY 2011, valamint T. SOMOGYI 2015: 208, TÓTH L. 2015: 203-206, VÁCZINÉ TAKÁCS 2016: 9-18). Az összefoglaló értelemben - s részben az itt említett terminusok helyett is - bevezetett irodalmi névtan kifejezés maga is friss terminológiai újításnak tekinthető (vö. TÓTH L. 2015: 206, ill. VÁCZINÉ TAKÁCS 2016: 17). Az irodalomban előforduló nevek különböző típusainak megnevezése - KOVALOVSZKY (1934) és mások korábbi, klasszikus munkáihoz képest - a kérdés elméleti átgondolását és terminológiai kidolgozását egyaránt joggal igényelte (1. pl. TÓTH L. 2015, VÁCZINÉ TAKÁCS 2016). A közelmúltban elkészült, illetve készülőben lévő doktori disszertációknak köszönhetően e részterületen számottevő elörelépések történtek, illetve várhatók még a következő években is.

5.2.5. A névkutatás további részterületeit, illetve aspektusait jelentik a nyelvhasználat különböző dimenzióihoz: az időbeliséghez, a térbeliséghez és a társadalmi(-kulturális) meghatározottsághoz kapcsolódó kutatások. E részterületek közül a legnagyobb hagyománnyal bíró történeti névtan (névtörténet) megnevezése sosem volt kérdéses, de kevéssé bizonyul problematikusnak a legfiatalabb részterület, a szocioonomasztika (avagy: névszociológia) elnevezése is. E terminusok a megfelelő nyelvtudományi diszciplínák bevett megnevezésének pontos megfelelői. (Ezekhez l. FARKAS 2014a, kül. 14-17.) A névhasználat területi változatosságát kutató részterületnek (illetve egyes kérdésköreinek) az elnevezésével viszont visszatérő módon foglalkozott a szakirodalom, különböző terminusokat ajánlva, illetve a használatban lévő vagy felmerült terminológiai megoldásokat értékelve. Ennek kérdését a dialektológiai kutatásokkal is foglalkozó névkutatók tartották napirenden az elmúlt évtizedekben (1. különösen ÖRDÖG 1989: 29, 1991, 2010; HAJDÚ 2002; JUHÁSZ 2004: 166-169, 2010: 31; a témakör újabb összefoglalására 1. FARKAS 2014a: 15, értékelésére is N. FODOR 2014: 24-27). A szóba került terminusok közül napjainkban mindenesetre a névföldrajz (vö. nyelvföldrajz) látszik a leginkább használatosnak. 
6. A nemzeti nyelvü névtani terminológia a nemzetközi névkutatás kontextusában. Legvégül, összefoglaló jelleggel is érdemes arra irányítani figyelmünket, hogy a nemzetközi és a magyar névtani terminológia, illetve a vonatkozó kutatások miképpen kapcsolódnak össze egymással.

6.1. A magyar névkutatás terminológiáját általában a magyar nyelvü terminusok jellemzik, az idegen nyelvi eredetüek kevéssé számítanak tipikusnak mellettük (FARKAS 2012: 141-142, SLÍZ 2014: 249-252). A nemzetközi terminusok közvetlen átvétele nem túl gyakori, az ezek inspirálta innovációk pedig különösen ritkák. (L. BAUKO JÁNOS speciális jelentésü, egyedi használatú, a szláv nyelvekben egyébként bevett terminológiai mintákat tükröző terminusait: gasztroantroponima, orohodonima; vö. BAUKO 2015a: $76,127$.$) Megjegyezhetjük ugyanakkor, hogy a magyar nyelvü, megszokott névtani ter-$ minusok közt akadnak olyanok, amelyek esetében elképzelhető az idegen - konkrétan: német - nyelvi minta követése, illetve tükörfordítással való keletkezésük. Ilyenek például a névkutatás (Namenforschung) és a helynév (Ortsname) terminusok (FARKAS 2012: 142).

Mindezek mellett előfordulhat az is, hogy magyar névtani terminusok, terminológiai innovációk idegen nyelvü megfelelőinek megalkotására, lefordítására van szükség. Ez a helyzet például a HOFFMANN-féle elméleti modellekre alapuló idegen nyelvű közlemények esetében (1. pl. HOFFMANN 1993: 153-162, TóTH V. 2005, HOFFMANN-TóTH 2015).

6.2. Más nyelvek névtani terminológiája, illetve a nemzetközi névkutatás terminológiai kérdésekkel való foglalkozása elméleti és gyakorlati haszonnal egyaránt járt a magyar névtudomány számára. A magyar névtani terminusok problematikáját érintő, illetve tárgyaló írások nem ritkán más nyelvek vonatkozó névtani terminológiájára, szemléletének tanulságaira is kitekintéssel íródtak, íródnak. Ez a többé vagy kevésbé kutatott részterületek, a hagyományosabb vagy az újabb terminusok esetében egyaránt elörevivőnek bizonyulhat (vö. pl. MIKESY 1960, HAJDÚ 2003: 151-153, VINCZE 2004: 187-188, FARKAS 2008: 336, RAÁTZ 2008: 444, BÖLCSKEI 2010: 84-85, HÁRI 2010: 102-103, TÓTH L. 2015). A nemzetközi és a magyar névtani terminológia bizonyos jellemzőinek összevetésére (SLíz 2014: 249-252), illetve különböző nyelvek névtani terminológiájának összehasonlítására (módszeresen, szlovák, illetve szláv vonatkozásban: BAUKO 2012; egy szükebb témakörben, finn-magyar összevetésben: TAKÁCS megj. e.) ugyancsak akadnak példák a magyar szakirodalomban.

Fontos feladat a vonatkozó magyar kutatási eredmények nemzetközi megismertetésének és hasznosíthatóságának biztosítása is. Néhány, a magyar névtani terminológia sajátságait, egyes kérdéseit tárgyaló tanulmány a közelmúltban idegen nyelven látott napvilágot (BÖLCSKEI 2013b, FARKAS 2014b, BAUKO 2015c). Az ICOS és az UNGEGN nemzetközi, több nyelven is elérhető névtani terminológiai glosszáriumának magyar (illetve magyar párú) változatát, valamint a kísérő tanulmányokat most közrebocsátó kötet pedig eleve kétnyelvü tartalommal, angol és magyar nyelven jelenik meg.

6.3. Az ICOS, illetve az UNGEGN aktuális nemzetközi névtani terminológiai jegyzékének magyar változata mellett rendelkezésre áll néhány korábban megjelent, kétnyelvü, magyar párú névtani glosszárium is (ezekről 1. már a fentebbiekben).

Megjegyzést érdemel továbbá, hogy magyar névkutatók is bekapcsolódtak az ICOS terminológiai munkacsoportjának tevékenységébe, és van magyar anyanyelvü résztvevője 
a szlovák névkutatók által megkezdett, többnyelvü elektronikus névtani terminológiai adatbázis munkálatainak is, amelyben a magyar terminusok is helyet kapnak majd (BAUKO 2015a: 73).

6.4. A hasonló munkák jól támogathatják a magyar és a nemzetközi névkutatás (illetve a kapcsolódó tudományterületek) közötti szakmai kommunikációt, melyhez elengedhetetlen a terminológiai megfelelések ismerete. A nemzetközi és a nemzeti nyelvű névtani terminológiára fordított együttes figyelem ugyanis természetszerüleg nemcsak elméleti tanulságai miatt fontos. Ez egyúttal a nemzetközi tudományos élet vérkeringéséhez való kapcsolódásnak is elengedhetetlen - az egyre erősödő nemzetközi látókörrel és kapcsolatrendszerrel rendelkező hazai névkutatás számára (vö. FARKAS 2015a: 33-41) tehát egyre fontosabbá váló - feltétele.

\section{Hivatkozott honlapok}

ICOS honlap $=$ https://www.icosweb.net/drupal/

ICOS terminológia $=$ https://icosweb.net/drupal/terminology

UNGEGN honlap $=\underline{\text { https://unstats.un.org/unsd/geoinfo/UNGEGN/ }}$

UNGEGN terminológia $=$ https://unstats.un.org/unsd/geoinfo/UNGEGN/publications.html

\section{Hivatkozott irodalom}

BAUKO JÁNOS 2009. Ragadványnév-vizsgálatok kétnyelvü környezetben. (Négy szlovákiai magyar település ragadványnévrendszere). Konstantin Filozófus Egyetem Közép-európai Tanulmányok Kara - Magyar Nyelvtudományi Társaság, Nyitra-Budapest.

BAUKO JÁNOS 2012. A magyar és a szlovák (szláv) névtani terminológia összevetése. Névtani Értesitő 34: 157-166.

BAUKO JÁNOS 2015a. Bevezetés a szocioonomasztikába. Nyitrai Konstantin Filozófus Egyetem Közép-európai Tanulmányok Kara, Nyitra.

BAUKo JÁNOs 2015b. Magyar névkutatás a határokon túl. In: FARKAS TAMÁs - Slíz MARIANN szerk., Magyar névkutatás a 21. század elején. Magyar Nyelvtudományi Társaság - ELTE Magyar Nyelvtudományi és Finnugor Intézet, Budapest. 63-89.

BAUKO, JÁN [JÁNOS] 2015c. Komparácia slovenských a mad’arských onomastických termínov. In: BALlEKOVÁ, KATARÍNA - KRÁLIK, L'UBOR - MúcsKovÁ, Gabriela eds., Jazykovedné štúdie XXXII. Prirodzený vývin jazyka a jazykové kontakty. Veda, Bratislava. 254-262.

BENKÖ LORÁND 1960. Megjegyzések terminus technikusokról. Magyar Nyelv 56: 238-40.

BEZlAJ, FranCE et al. 1983. Osnoven sistem i terminologija na slovenskata onomastika. Osnovnaja sistema i terminologija slavjanskoj onomastiki. Grundsystem und Terminologie der slawischen Onomastik. Makedonska akademija na naukite i umetnostite - Megunaroden komitet na slavistite - Komisija za slovenska onomastika, Skopje.

BÖLCSKEI ANDREA 2010. A magyar településnevek korrelációs rendszerének alakulása a természetes névadás korszakában. A Károli Gáspár Református Egyetem Magyar Nyelvtudományi Tanszékének Kiadványai 2. Károli Gáspár Református Egyetem Magyar Nyelvtudományi Tanszéke, Budapest.

BÖLCSKEI ANDREA 2012. A helynév-standardizáció terminológiájáról. Névtani Értesitö 34: 167-178. 
BÖLCSKEI ANDREA 2013a. Az „UNGEGN Glossary of Terms for the Standardization of Geographical Names" címü terminusjegyzék magyar változatának elkészítéséröl. Névtani Értesitő 35: 11-21.

BÖLCSKEI ANDREA 2013b. Challenges in updating the Hungarian terminology for geographical names standardization. Magyar Terminológia 6/2: 153-168. https://doi.org/10.1556/1206.2013. $\underline{6.2 .3}$

BÖLCSKEI ANDREA 2017. Két nemzetközi névtani terminológiai jegyzék magyar változata. In: BÖlCSKeI ANDREA - FARKAS TAMÁs - Slíz MARIANn szerk., Magyar és nemzetközi névtani terminológia / Hungarian and International Onomastic Terminology. International Council of Onomastic Sciences - Magyar Nyelvtudományi Társaság, Uppsala-Budapest. 49-61. https://doi. org/10.26546/5061110.8

BölCSKEI ANDREA - FÓRIS ÁGOTA 2012. Névtan és terminológia 2: Névtan és egységesítés. Névtani Értesitö 34: 125-126.

Brendler, Andrea - Brendler, Silvio Hrsg. 2004. Namenarten und ihre Erforschung. Ein Lehrbuch für das Studium der Onomastik. Lehr- und Handbücher zur Onomastik 1. BaarVerlag, Hamburg.

BuCSKO-TKACSOVA 2012. = БУЧКО, ДМИТРО ГРИГОРОВИЧ - ТКАЧОВА, НАТАЛІЯ ВАСИЛІВНА 2012. Словник украӥнської ономастичної термінологї̈. Ранок, Харків.

DORION, Henri - PoIrier, JeAn 1975. Lexique des termes utiles à l'étude des noms de lieux. French and European Publications Inc., Quebec.

FÁBIÁN, ZsUZSANNA 2001. Glossario dei termini piú importanti dell'Onomastica. In: FÁBIÁn, Zsuzsanna ed., Antologia di Onomastica Italiana. Eötvös Loránd Tudományegyetem Bölcsészettudományi Kar Olasz Nyelv és Irodalom Tanszék, Budapest. 291-299.

FARKAS TAMÁS 2008. Szemlélet és terminológia a névkutatásban: a hivatalos magyar családnévváltoztatások kérdései. In: BölCSKEI ANDREA - N. CSÁSZI ILDIKÓ szerk., Név és valóság. $A$ VI. Magyar Névtudományi Konferencia elöadásai. Balatonszárszó, 2007. június 22-24. A Károli Gáspár Református Egyetem Magyar Nyelvtudományi Tanszékének Kiadványai 1. Károli Gáspár Református Egyetem Magyar Nyelvtudományi Tanszéke, Budapest. 332-341.

FARKAS TAMÁS 2011. Terminológiai munkálatok a névkutatás területén. Névtani Értesitô 33: 203-212.

FARKAS TAMÁS 2012. Szempontok a magyar névtani terminológia megítéléséhez. Névtani Értesitö 34: 139-148.

FARKAS TAMÁS 2013. Egy magyar névtani terminológiai szótár tervéröl. In: TóTH SzERGEJ szerk., Társadalmi változások - nyelvi változások. Alkalmazott nyelvészeti kutatások a Kárpátmedencében. A XXII. MANYE Kongresszus elöadásai. Szeged, 2012. április 12-14. A MANYE Kongresszusok Előadásai 9. MANYE - Szegedi Egyetemi Kiadó Juhász Gyula Felsőoktatási Kiadó, Budapest-Szeged. 442-445.

FARKAS TAMÁs 2014a. Dimenzionális szemlélet a névkutatásban. Általános kérdések és a családnévkutatás példája. Névtani Értesitó 36: 9-22.

FARKAS, TAMÁs 2014b. Onomastic Terminology in Hungarian - Situation, Problems and Needs. In: Tort i Donada, JoAn - Montagut i Montagut, Montserrat eds., Els noms en la vida quotidiana. Actes del XXIV Congrés Internacional d'ICOS sobre Ciències Onomàstiques. / Names in daily life. Proceedings of the XXIV ICOS International Congress of Onomastic Sciences. Biblioteca Tècnica De Política Lingüística 11. Generalitat de Catalunya, Barcelona. 14-20. http://www.gencat.cat/llengua/BTPL/ICOS2011/003.pdf és https://doi.org/10.2436/15. $\underline{8040.01 .3}$ 
FARKAS TAMÁS 2015a. A nemzetközi névkutatás és magyar kapcsolatai. In: FARKAS TAMÁs - SLíz MARIANN szerk., Magyar névkutatás a 21. század elején. Magyar Nyelvtudományi TársaságELTE Magyar Nyelvtudományi és Finnugor Intézet, Budapest. 23-47.

FARKAS TAMÁS 2015b. A magyar családnevek változástipológiájáról. Magyar Nyelv 111: 395-408. https://doi.org/10.18349/MagyarNyelv.2015.4.395

FeHÉRTÓi KATALIN 1966. A német névtudomány két újdonsága. Magyar Nyelv 62: 245-247.

N. FodOR JÁNOS 2010. Személynevek rendszere a kései ómagyar korban. A Felsö-Tisza-vidék személyneveinek nyelvi elemzése (1401-1526). Magyar Névtani Értekezések 2. ELTE BTK Magyar Nyelvtörténeti, Szociolingvisztikai, Dialektológiai Tanszéke, Budapest.

N. FODOR JÁNOS 2014. A történeti személynévföldrajz mint a nyelvföldrajz egyik kutatási területe I. A nyelvföldrajzi módszer a névtani kutatásokban. Névtani Értesitő 36: 23-41.

FÖLDI ERVIN 1979. Elöterjesztés a tenger alatti domborzati nevekről. A Földrajzinév-bizottság 32. ülésének jegyzőkönyve. Kézirat, Budapest.

FÖLDI ERVIN 1992. ENSZ földrajzinév-egységesítési szakkifejezések szótára. Névtani Értesitő 14: $127-138$.

Galkowski, ARTUR 2010. Problemi di terminologia onomastica. Contributi per un dibattito. Rivista Italiana di Onomastica 16: 604-624.

GAŁKOWSKI, ARTUR 2012. Aktualizowana lista podstawowych haset terminologii onomastycznej w języku polskim. http://onomastyka.uni.lodz.pl/strona-glowna/terminologia-polska

B. Gergely Piroska 2007. Hajdú Mihály: Általános és magyar névtan. Magyar Nyelvőr 131: $253-258$.

GYÖRFFY ERZSÉBET 2007. A svéd névtudományról és helynévkutatásról. Névtani Értesitő 29: $247-257$.

GYÖRFFY ERZSÉBET 2012. A hivatalos név terminus. Magyar Nyelvjárások 50: 27-35.

HAJdú MıHÁLy 1974a. Vitainditó a névtudomány müszavairól. Bokor Levelek 12. Sokszorosított kiadvány, Budapest.

HAJDÚ MıHÁLY 1974b. Előterjesztés a magyar névtudomány müszavainak egységesitéséről. Sokszorosított kiadvány, Budapest.

HAJdÚ MiHÁLY 1979. A magyar névtudomány müszavai. Névtani Értesitő 2: 18-28.

HaJdú MiHÁLy 1981. J. Soltész Katalin, A tulajdonnév funkciója és jelentése. Magyar Nyelv 77: $109-113$.

Hajdú Mihály 2002. Tulajdonnév és dialektológia. In: SZABó GÉZA - MolnÁR Zoltán GutTMAnn MikLós szerk., IV. Dialektológiai Szimpozion. Szombathely, 2001. augusztus 23-25. A Berzsenyi Dániel Tanárképző Főiskola Magyar Nyelvészeti Tanszékének Kiadványai V. Berzsenyi Dániel Föiskola Magyar Nyelvészeti Tanszéke, Szombathely. 104-119.

HAJdú MihÁly 2003. Általános és magyar névtan. Személynevek. Osiris Kiadó, Budapest.

Hajdú MihÁly 2006. Álnév - fedőnév - jelige - internetnév. In: MÁRTONFi AtTila - PAPP KornÉlia - Slíz Mariann szerk., 101 írás Pusztai Ferenc tiszteletére. Argumentum, Budapest. 257-66.

HAJDÚ MiHÁLy 2009. A névváltozások és névváltoztatások rendszere. In: FARKAS TAMÁs - KozMA IsTVÁN szerk., A családnév-változtatások történetei időben, térben, társadalomban. Gondolat Kiadó - Magyar Nyelvtudományi Társaság, Budapest. 29-40.

Hajdú MinÁly 2010. Közös tervek Mező Andrással. In: P. LAKATos IlonA - Sebestyén Zsolt szerk., Emlékkönyv Mezö András tiszteletére. Bessenyei Könyvkiadó, Nyíregyháza. 23-28.

HAJdú MıHÁLy 2011. Farkas Tamás, Családnév-változtatás Magyarországon. Magyar Nyelv 107: 345-347. 
HÁRi GyUla 2010. Épületnév, építménynév, létesítménynév. Névtani Értesitő 32: 99-116.

HaRVALíK, MiLAN 2005. Towards a new millennium - towards a common onomastic terminology? In: Brylla, Eva - WAHLberg, MAts eds., Proceedings of the 21st International Congress of Onomastic Sciences. Uppsala 19-24 August 2002. Språk- och folkminnesinstitutet, Uppsala. 1: $160-171$.

HARVALíK 2007. = ГАРВАлИК, МилАН 2007. К вопросу о современной ономастической терминологии. Вопросы ономастики 4: 5-13.

HaRVALíK, Milan 2014. Towards a common onomastic terminology? The next step. In: TORT Donada, Joan - Montagut i Montagut, Montserrat eds., Els noms en la vida quotidiana. Actes del XXIV Congrés Internacional d'ICOS sobre Ciències Onomàstiques. / Names in daily life. Proceedings of the XXIV ICOS International Congress of Onomastic Sciences. Biblioteca Tècnica De Política Lingüística 11. Generalitat de Catalunya, Barcelona. 21-25. http://www. gencat.cat/llengua/BTPL/ICOS2011/004.pdf és https://doi.org/10.2436/15.8040.01.4

HaRVALÍK, Milan - CAFFARELli, EnZO 2007. Onomastic terminology: an international survey / Terminologia onomastica: un'inchiesta internazionale. Rivista Italiana di Onomastica 13: 181-220.

HENNO, KAIRIT - PÄLL, PEETER 2003. Onomastika termineid. http://www.eki.ee/nimeselts/nimeterm.htm

Hoffmann István 1993. Helynevek nyelvi elemzése. A Debreceni Kossuth Lajos Tudományegyetem Magyar Nyelvtudományi Intézetének Kiadványai 61. Debreceni Kossuth Lajos Tudományegyetem Magyar Nyelvtudományi Intézete, Debrecen.

HofFMANN IstvÁN 1999. A helynevek rendszerének nyelvi leírásához. Magyar Nyelvjárások 37 207-216.

HofFMANN IsTVÁN 2002. Magyar névkutatás az ezredfordulón. In: HofFMANN IsTVÁN - JUHÁsz DEZSÖ - PÉNTEK JÁNOS szerk., Hungarológiai és dimenzionális nyelvszemlélet. Elöadások az V. Nemzetközi Hungarológiai Kongresszuson. K. n., Debrecen-Jyväskylä. 9-22.

HofFMANN IstVÁn 2003. Magyar helynévkutatás 1958-2002. A Magyar Névarchívum Kiadványai 7. Debreceni Egyetem Magyar Nyelvtudományi Tanszék, Debrecen.

HoFFMANN ISTVÁN $2007^{2}$. Helynevek nyelvi elemzése. Segédkönyvek a nyelvészet tanulmányozásához 67. Tinta Könyvkiadó, Budapest.

HoFFMANN IsTVÁN 2008. A személynévrendszerek leírásához. Magyar Nyelvjárások 46: 5-20.

HoFFMANN ISTVÁN 2012. Elmélet és terminológia a magyar helynévkutatásban. Névtani Értesitő 34: 127-137.

HOFFMANN, ISTVÁN - TÓTH, VALÉRIA 2015. Viewpoints on the cognitive-pragmatic description of personal names. Word: Journal of the International Linguistic Association 61: 141-164. https://doi.org/10.1080/00437956.2015.1033832

JuHÁsz DEZsŐ 2004. A névtan néhány terminológiai és tudományrendszertani kérdéséről. In: FARKAS FERENC szerk., Magyar névtani kutatások itthon és határainkon túl. Névtani tanácskozás Jászberényben. 2003. október 17-18. Magyar Nyelvtudományi Társaság - Szent István Egyetem Jászberényi Főiskolai Kar - TIT Jászsági Szervezete - Jászok Egyesülete, Budapest. 165-169.

JuHÁsz DEZső 2010. A személynevek mint a nyelvföldrajz tárgyai. In: VöRÖs FERENC szerk., A nyelvföldrajztól a névföldrajzig. A 2010. június 8-i szombathelyi tanácskozás elöadásai. A Magyar Nyelvtudományi Társaság Kiadványai 234. Magyar Nyelvtudományi Társaság - NyME Savaria Egyetemi Központ, Budapest-Szombathely. 31-39.

KAlETA, ZoFiA 1998. Kierunki i metodologia badań. Terminologia. In: RZETELSKA-FELESZKo, EwA ed., Polskie nazwy własne. Encyklopedia. Wydawnictwo Instytutu Języka Polskiego PAN, Warszawa-Kraków. 45-81. 
KÁlmÁn BÉla 1982. Névtani Értesítő. Szerk. Hajdú Mihály és Mező András. 2-5. szám. Magyar Nyelv 78: 502-505.

Kiviniemi, EERO - PitKÄNEN, RitVA-LiISA - ZilliaCUS, KuRT eds. 1974. Nimistöntutkimuksen terminologia. Terminologin inom namnforskningen. Castrenianumin toimitteita 8. Castrenianum, Helsinki.

KOROMPAY KLÁRA 2011. Az irodalmi névadás fogalmáról. Létünk 41/3: 86-93.

Kovalovszky Miklós 1934. Az irodalmi névadás. A Magyar Nyelvtudományi Társaság Kiadványai 34. Magyar Nyelvtudományi Társaság, Budapest.

Marcato, CARLa 2009. Nomi di persona, nomi di luogo. Introduzione all'onomastica italiana. Il Mulino, Bologna.

MÁRTON MÁTYÁs 1992. A magyar tengerfenék-domborzati nevek megalkotásáról. Névtani Értesitő 14: 84-116.

MÁRTON MÁTYÁs 2012. A világtenger kartográfus szemmel. Eötvös Loránd Tudományegyetem Informatikai Kar Térképtudományi és Geoinformatikai Tanszék, Budapest.

MÁRTON MÁTYÁs - DuTKÓ ANDRÁs ÁKOS szerk. 2003. Standardization of Undersea Feature Names / Tengerfenék-domborzati képződmények neveinek egységesitése. Angol-magyar változat. Kézirat, Budapest.

MiKeSY SÁNDOR 1959. Írói névadás - irodalmi névadás. Magyar Nyelv 55: 110-112.

MiKeSY SÁNDOR 1960. Mi legyen az onomasztika magyar neve? Magyar Nyelv 56: 236-238.

MizSER LAJOS 1979. Három finn névtudományi munka. Magyar Nyelv 75: 246-250.

NiMCSUK 1966 = НІмчУк, ВАСиль ВАСильович 1966. Українська ономастична термінологія. Повідомлення Украӥнської ономастичної комісії 1: 24-43.

NYSTRÖM, STAFFAN 2014. The terminological work of UNGEGN and ICOS - a presentation and a comparison. In: TORT I DONADA, JOAN - MONTAGUT I MONTAGUT, MONTSERRAT eds., Els noms en la vida quotidiana. Actes del XXIV Congrés Internacional d'ICOS sobre Ciències Onomàstiques. / Names in daily life. Proceedings of the XXIV ICOS International Congress of Onomastic Sciences. Biblioteca Tècnica De Política Lingüística 11. Generalitat de Catalunya, Barcelona. 52-57. http://www.gencat.cat/llengua/BTPL/ICOS2011/008.pdf és https://doi.org/10.2436/15.8040.01.8

ÖRDÖG FERENC 1989. Helynévgyüjteményeink mint az onomatodialektológia forrásai. Baranyai Müvelödés 1989/3: 27-33.

ÖRDÖG FERENC 1991. Személyneveink onomato-dialektológiai vizsgálatáról. In: HAJDÚ MiHÁLY szerk., Emlékkönyv Benkö Loránd hetvenedik születésnapjára. ELTE, Budapest. 488-496.

ÖRDÖG FERENC 2010. Névföldrajz, onomatodialektológia, névdialektológia. In: VöRÖs FERENC szerk., A nyelvföldrajztól a névföldrajzig. A 2010. június 8-i szombathelyi tanácskozás elöadásai. A Magyar Nyelvtudományi Társaság Kiadványai 234. Magyar Nyelvtudományi Társaság, Budapest-Szombathely. 127-133.

PAPP LÁszló 1955. Szabó István: Bács, Bodrog és Csongrád megye dézsmalajstromai 1522-ből. Magyar Nyelv 51: 258-263.

PETR, JAN 1969. Lužickosrbská onomastická terminologie. Zpravodaj Mistopisné komise ČSAV 10: 538-552.

PODOLSZKAJA $1978^{1}=$ ПОДОЛЬСКАЯ, НАТАЛЬЯ ВЛАДИМИРОВНА $1978^{1}$. Словарь русской ономастической терминологии. Наука, Москва.

PODOLSZKAJA $1988^{2}$ = ПодОЛЬСКАЯ, НАТАЛЬЯ ВЛАДИМИРОВНА $1988^{2}$. Словарь русской ономастической терминологии. Наука, Москва.

PoKOly BÉLA 2013. Az exonima kifejezés értelmezésének változása a földrajzinév-egységesítés nemzetközi gyakorlatában. Névtani Értesítö 35: 71-75. 
Pokoly, Béla - BölCSKei, Andrea - Mikesy, GÁBOr 2015. The exonym/endonym divide: Examples highlighting different aspects for defining the terms. In: JORDAN, PETER - WoOdMAN, PAUL eds., Confirmation of the Definitions. Proceedings of the 16th UNGEGN Working Group on Exonyms Meeting, Hermagor, 5-7 June 2014. Verlag Dr. Kovac, Hamburg. 155-168.

RAÁTZ JUDIT 1999. Intern Otto, Angicica, Lütyő és a többiek, azaz névválasztás a számítógépes csevegőcsatornán. Névtani Értesitő 21: 262-266.

RAÁTZ Judit 2008. Névadás az interneten. In: BölCSKEI ANDREA - N. CsÁSZI Ildikó szerk., Név és valóság. A VI. Magyar Névtudományi Konferencia elöadásai. Balatonszárszó, 2007. június 22-24. A Károli Gáspár Református Egyetem Magyar Nyelvtudományi Tanszékének Kiadványai 1. Károli Gáspár Református Egyetem Magyar Nyelvtudományi Tanszéke, Budapest. 443-450.

RoOM, Adrian 1996. An Alphabetical Guide to the Language of Name Studies. The Scarecrow Press, Lanham (MD) - London.

Rzetelska-Feleszko, Ewa - Cieślikowa, Aleksandra - Duma, Jerzy red. 2002-2003. Stowiańska onomastyka. Encyklopedia 1-2. Towarzystwo Naukowe Warszawskie, WarszawaKraków.

SCHMIDT, TOM 1981. Fagordliste for norsk namnegransking. Institutt for namnegransking Universitetet i Oslo, Oslo.

SLíz MarianN 2010. A történeti személynévkutatás terminológiájához. Névtani Értesitő 32: 157-172.

SLíz MARIANN 2012. Terminusok keletkezése és változása. Névtani Értesitő 34: 149-156.

SLíz MARIANN 2014. A terminológiai egységesülés hiányának következményei a névtudományban. In: Lengyel KLÁRA - VeSZELSZKi ÁGNES szerk., Tudomány, technolektus, terminológia. A tudományok, szakmák nyelve. Éghajlat Könyvkiadó, Budapest. 249-258.

SLíz MARIANN 2015. Ảltalános névtani kérdések. In: FARKAS TAMÁs - SLíz MARIANN szerk., Magyar névkutatás a 21. század elején. Magyar Nyelvtudományi Társaság - ELTE Magyar Nyelvtudományi és Finnugor Intézet, Budapest. 93-114.

SLíz MARIANN megj. e. A személynevekkel kapcsolatos névtani és jogi terminológia. Megjelenés elött.

Smith, Elsdon Coles 1967. Treasury of Name Lore. Sketches and Observations on the Names We Bear. Harper \& Row, New York - Evanston - London.

J. SoltÉSZ KATALIN 1979. A tulajdonnév funkciója és jelentése. Akadémiai Kiadó, Budapest.

T. SOMOGYi MAGDA 2015. Az írói névadás vizsgálata. In: FARKAS TAMÁS - SLíz MARIANN szerk., Magyar névkutatás a 21. század elején. Magyar Nyelvtudományi Társaság - ELTE Magyar Nyelvtudományi és Finnugor Intézet, Budapest. 207-226.

Svoboda, JAN - Šmilauer, Vladimír - OlivovÁ-NeZBedovÁ, LibuŠE - Oliva, Karel - WitKowski, THEODOLIUS 1973. Základní soustava a terminologie slovanské onomastiky. Grundsystem und Terminologie der slawischen Onomastik. Zpravodaj Mistopisné komise ČSAV 14: 1-280.

SzENTGYÖRGYI RUdOLF 2016. A Tihanyi alapítólevél személynevei III. Személynevek és helynevek kapcsolata. Névtani Értesitö 38: 9-18.

TAKÁCS JUDIT megj. e. Finn-magyar kontrasztív névtani (terminológiai) vizsgálatok a személynévtípusok megnevezésének köréből. Megjelenés előtt.

TóTH LÁszLó 2015. Alapfogalmak az irodalmi onomasztikában. Acta Academiae Agriensis Sectio Linguistica Hungarica 42: 203-215.

Tóth, VALÉRIA 2005. The Changes of the Hungarian Settlement Names. In: MATICSÁK, SÁNDOR ed., Settlement Names in the Uralian Languages. Onomastica Uralica 3. K. n., DebrecenHelsinki. 135-153. 
TÓTH VALÉRIA 2008. Településnevek változástipológiája. A Magyar Névarchívum Kiadványai 14. Debreceni Egyetem Magyar Nyelvtudományi Tanszéke, Debrecen.

UdVARI ISTVÁN 1981. Н. В. Подольская: Словарь русской ономастической терминологии. Névtani Értesitö 6: 71-3.

VÁCZINÉ TAKÁCs EDIT 2016. Az irói névadás sajátosságai Karinthy Frigyes müvei alapján bemutatva. Doktori (PhD) értekezés. ELTE BTK, Budapest. https://doi.org/10.15476/ELTE.2016.147

VÁRnAi Judit SzILvia 2005. Bárhogy nevezzük... A tulajdonnév a nyelvben és a nyelvészetben. Segédkönyvek a nyelvészet tanulmányozásához 42. Tinta Könyvkiadó, Budapest.

VÁRNAI JUdit SzILVIA szerk. é. n. Angol-magyar nyelvészeti glosszárium / English-Hungarian glossary of linguistical terms. http://mnytud.arts.klte.hu/glossary.htm és http://mnytud.arts.klte. hu/glosseng.htm

VASILEVA, NATALIA 2014. Koordinierung der onomastischen Terminologie: die Suche nach der lexikographischen Lösung. In: Tort i Donada, JoAN - Montagut i Montagut, Montserrat eds., Els noms en la vida quotidiana. Actes del XXIV Congrés Internacional d'ICOS sobre Ciències Onomàstiques. / Names in daily life. Proceedings of the XXIV ICOS International Congress of Onomastic Sciences. Biblioteca Tècnica De Política Lingüística 11. Generalitat de Catalunya, Barcelona. 99-106. http://www.gencat.cat/llengua/BTPL/ICOS2011/013.pdf és https://doi.org/10.2436/15.8040.01.13

VINCZE LÁSZLÓ 2004. A magyar belterületi helynevek kutatásában elért eddigi eredmények és további feladatok (A hazai és külföldi teljesítmények összevetése). In: FARKAS FERENC szerk., Magyar névtani kutatások itthon és határainkon túl. Névtani tanácskozás Jászberényben. 2003. október 17-18. Magyar Nyelvtudományi Társaság - Szent István Egyetem Jászberényi Főiskolai Kar - TIT Jászsági Szervezete - Jászok Egyesülete, Budapest. 187-191.

VÖRÖS FERENC 2009. Névváltoztatás és névhelyreállitás a kisebbségi magyar névhasználat tükrében: terminológiai javaslat egy névtani jelenség megnevezésére. In: FARKAS TAMÁs - KOZMA IsTVÁN szerk., A családnév-változtatások történetei idöben, térben, társadalomban. Gondolat Kiadó Magyar Nyelvtudományi Társaság, Budapest. 57-74.

WALTHER, HANS 1998. Namenkunde und geschichtliche Landeskunde 2. Erläuterung namenkundlicher Fachbegriffe. Universität Leipzig Institut für Slavistik, Leipzig.

WitKowsKi, TEODOLIUs 1964. Grundbegriffe der Namenkunde. Akademie Verlag, Berlin.

Witkowski, Teodolius 1995. Probleme der Terminologie. In: Eichler, ERnST et al. eds., Namenforschung / Name Studies / Les noms propres. Ein internationales Handbuch zur Onomastik / An International Handbook of Onomastics / Manuel international d'onomastique. Handbücher zur Sprach- und Kommunikationswissenschaft 11. Walter de Gruyter, Berlin - New York. 1: $288-294$.

FARKAS TAMÁS

ORCID: 0000-0002-7732-2302

ELTE Eötvös Loránd Tudományegyetem Magyar Nyelvtudományi és Finnugor Intézet Budapest 

BÖLCSKEI-FARKAS-SLíz szerk., Magyar és nemzetközi névtani terminológia. Hungarian and International Onomastic Terminology. International Council of Onomastic Sciences - Magyar Nyelvtudományi Társaság, Uppsala-Budapest, 2017. 49-61. DOI: $10.26546 / 5061110.8$

\section{Két nemzetközi névtani terminológiai jegyzék magyar változata}

1. Két nemzetközi névtani terminológiai szójegyzék. A jelen kötetben közreadott két nemzetközi névtani terminológiai szójegyzéket tulajdonnevekkel foglalkozó nemzetközi tudományos, szakmai társaságok terminológiai munkálatokra szakosodott munkacsoportjai alkották meg, eltérő céllal. Az ICOS (International Council of Onomastic Sciences), azaz a Nemzetközi Névtudományi Társaság szakemberei általánosságban a névtan tudományterületének alapvető, elsősorban a szűkebb szakmai kommunikáció során alkalmazott szakkifejezéseit gyüjtötték össze, látták el értelmező magyarázatokkal, s tették közzé a névtani terminológiára vonatkozó megjegyzések, szakirodalmi hivatkozások kíséretében. Az UNGEGN (United Nations Group of Experts on Geographical Names), azaz az ENSZ Földrajzi Névi Szakértői Csoportja munkatársai a földrajzinévegységesítési tevékenység során használatos nyelvészeti, földrajzi, térképészeti, dokumentációs és információtechnológiai vonatkozású terminusok jegyzékét készítették el, a helynevek standardizálásának gyakorlati munkájában részt vevő szakemberek számára. Az alábbiakban e két, különböző jellegű nemzetközi névtani terminológiai glosszárium keletkezési körülményeiröl, jellemzőiről, valamint a magyar változatok elkészítésének elveiröl és módjáról nyújtunk rövid tájékoztatást.

2. Az ICOS fóbb törekvései. Az 1949-ben alapított Nemzetközi Névtudományi Társaság 2002-ben megszövegezett, jelenleg érvényes alapszabályzatában céljai között a névtudomány nemzetközi színtéren és interdiszciplináris keretek között való előmozdítását, koordinálását, valamint rendszeres tudományos-szakmai találkozók rendezését jelöli meg. A szervezet korábbi és jelenlegi sikeres müködéséhez nagyban hozzájárul két állandó munkacsoport, a bibliográfiai (ICOS Bibliography Group) és terminológiai munkacsoport (ICOS Terminology Group) tevékenysége is (Icosweb, FARKAS 2015: 23-24, 26-27, 28, 31).

Az ICOS Terminológiai Munkacsoportjának létrehozását a 2002-es uppsalai ICOSkongresszuson a cseh Milan Harvalík, az ICOS jelenlegi elnöke kezdeményezte. A munkacsoport 2004-ben kezdte meg müködését, s az Icosweb honlapjának Terminology aloldalán 2011-ben két kisebb terjedelmü terminusjegyzéket tett közzé (vö. HARVALÍK 2005, 2014). Az egyik jegyzék néhány angol nyelvü, föként a szük szakmai közösség által használatos névtani szakkifejezést tartalmaz, a jelentés rövid meghatározásával, valamint közöl néhány, a névtani terminusok nyelvi jellemzőivel kapcsolatos általános megjegyzést is (Icosweb Terminology). A másik terminusgyüjtemény 70 alapvető 
névtani szakkifejezést sorol fel és definiál angol, francia és német nyelven (Lists of Key Onomastic Terms, 1. Icosweb Terminology). ${ }^{1}$

2.1. Az ICOS alapvető névtani terminusokat tartalmazó szójegyzéke. A 70 alapvető névtani terminust magában foglaló jegyzéket a munkacsoport tagjai angol nyelvre dolgozták ki. A szójegyzékben a terminusok formájának, jelentésének meghatározásán túl egyes szakkifejezések kapcsán illusztratív példákat is találunk. Néhány terminussal összefüggésben a jelentésre (pl. anthroponymy, hagionym, oronym), a formára ( $\mathrm{pl}$. metronym), a tulajdonnévi jellegre (pl. ethnonym, inhabitant name), illetve a használatra (pl. first name, odonym) vonatkozó megjegyzéseket, javaslatokat is olvashatunk. Más esetekben a terminusok alá-, fölé-, mellérendeltségi viszonyairól (hiponimák, hiperonimák, kohiponimák) tájékoztatják a szerkesztők az olvasót (1. pl. a nickname és a by-name, a street name és a hodonym, a choronym és a macrotoponym kapcsolatát); míg az utaló címszavak a szinonim terminusokról, illetve a terminusvariációkról nyújtanak információkat (1. pl. az animal name és zoonym, a minor name és microtoponym, a name bearer és denominatum esetét).

A szójegyzék francia és német nyelvü változata az angol terminuslista alapján készült, nem egészen azonos szemléletet alkalmazva. Míg a francia jegyzék a nemzeti nyelvü szakkifejezéseket előtérbe állító szükebb értelemben vett fordítása az angol terminuslistának, addig a német változat előbb megadja a nemzeti nyelvü szakkifejezés angol megfelelöjét, majd a terminus definíciója, illetve, ha van ilyen, a megjegyzés következik. A német változat néhánnyal több, nyelvspecifikus megjegyzést tartalmaz, mint az eredeti, angol glosszárium (1. pl. az Anthroponym, Appellativierung, Beiname, Mikrotoponym címszavakhoz füzött megjegyzéseket). A német szójegyzékben van továbbá néhány olyan, fơként német eredetủ utaló címszó is, amely mellett angol megfelelő nem szerepel, mivel azt a definícióval együtt a szinonim szakkifejezésnél találjuk meg a listában (1. pl. a Deckname, Gewässername, Kosename, Riedname utaló címszavakat).

Mind a francia, mind a német változat készítői szembesültek néhány jellemzö, a nyelvek közötti terminológiai munkát kísérő problémával: így esetenként választaniuk kellett a nemzetközi hátterü, illetve a nemzeti nyelvi eredetü terminus önálló szócikk címszavaként való alkalmazása között; kezelniük kellett a terminushiány és a terminustöbblet eseteit. A német változatban a fent említett utaló címszavak a nemzetközi jellegü szinonim szakkifejezések önálló szócikkeihez utalnak (azaz a Kryptonym, Hydronym, Hypokoristikon, Mikrotoponym címszavakkal felvezetett szócikkekhez), így a nemzetközi hátterủ terminusok némiképp előtérbe kerülnek a nemzeti nyelvi eredetüekkel szemben. Hasonló módon (önálló és utaló címszavak útján) kezeli a német szójegyzék azokat az eseteket is, amelyekben egy-egy angol terminusnak több német eredetü vagy több nemzetközi hátterü szakkifejezés feleltethető meg a német nyelvben (pl. nickname $=$ Neckname utaló és Spitzname önálló címszó; deonym = Epotoponym utaló és Deonym önálló címszó).

\footnotetext{
${ }^{1}$ Az ICOS hivatalos nyelvei. Az angol és a német glosszáriumban megtaláljuk továbbá a névtani terminológia 1961-2002 között kiadott művekből összeállított válogatott nemzetközi bibliográfiáját is.
} 
Különbségek figyelhetők meg a nyelvek között abban a tekintetben is, hogy egy-egy fogalom jelölésére hagyományosan hány szinonim értékü terminust használnak. A német szójegyzékben - amennyiben a szinonim szakkifejezések száma a német nyelvben kevesebb, mint az angolban - néhány német szakkifejezés mellé több angol megfelelő is került (pl. Familienname = family name, surname, last name önálló címszó és az ide vezető Zuname utaló címszó; Vorname = first name, given name önálló címszó és az ide vezető Taufname $=$ Christian name utaló címszó). A francia szójegyzékből, mivel abban angol megfelelőket nem találunk, egy-egy fogalom kapcsán a szinonim terminusok hiánya csak áttételesen deríthető ki (így pl. a nom de famille és a prénom kifejezésekre utaló címszó nincsen). Mind a német, mind a francia változat beilleszt egy-egy, az eredeti terminusjegyzékből hiányzó önálló szócikket (vö. a francia toponymiste és a német onymisch szócikkeit).

Az ICOS alapvető névtani terminusokat tartalmazó szójegyzéke sikeresen írja le a tárgyalt szakkifejezések tényleges használatával kapcsolatos jellemzöket; mutatja ezt az is, hogy a terminusjegyzék a szakemberek részéről megerősítésre talált. A névtani szakkifejezések e jegyzék szerinti használata az ICOS kiadványaiban, kongresszusain, valamint egyéb névtudományi témájú írásokban, konferenciákon egyre inkább kívánalomként fogalmazódik meg.

2.2. Az ICOS-terminusjegyzék magyar változata. A szójegyzék további nemzeti nyelvü változatainak elkészítésére való igény az ICOS Terminológiai Munkacsoportnak a téma iránt érdeklődő névkutatókkal kibővített, 2011. szeptember 6-i barcelonai ülésén nyilvánosan is megfogalmazódott, s a kívánalom megerösítést nyert a munkacsoport hasonló módon szervezett 2014. augusztus 26-i glasgow-i ülésén. Itt a jelenlévők vállalták, hogy gondoskodnak a terminusjegyzék anyanyelvükre való átdolgozásáról, közreadásáról. A glasgow-i megbeszélésen magyar részről Bölcskei Andrea, Farkas Tamás és Slíz Mariann vettek részt. Az ICOS alapvető névtani terminusokat tartalmazó szójegyzékének magyar változatát, a kapcsolódó magyar-angol mutatóval, valamint egy, az angolmagyar-német-francia terminusekvivalenciákat megadó négynyelvü jegyzékkel együtt Bölcskei Andrea szakmai felügyelete mellett Oláh Bence Attila egyetemi hallgató (KRE BTK, anglisztika alapképzés, fordítói-szaknyelvi specializáció, majd terminológia mesterképzés) készítette el 2015-ben.

A terminusjegyzék magyar változatának elkészítése során több, a fentiekhez hasonló, a nyelvek közötti terminológiai harmonizációt, a definíciók megfogalmazását, az illusztratív példák megválasztását, illetve a szójegyzék szerkezetének kialakítását érintő problémát kellett megoldani. A munka során alkalmazott alapelveket, szükség esetén példákkal illusztrálva, az alábbiakban mutatjuk be.

A magyar terminusjegyzék, akárcsak a német és a francia változatok, az eredeti, angol nyelvü glosszárium alapján készült. A szójegyzék szerkezetét tekintve az volt a cél, hogy feltüntessük az angol-magyar terminusekvivalenciákat; megtartsuk az önálló és utaló szócikkeknek az eredeti glosszáriumban alkalmazott rendszerét; továbbá hogy a jegyzék formailag és tartalmilag illeszkedjen a szintén e kötetben közreadott, földrajzinévegységesítési szakkifejezéseket taglaló UNGEGN-listához (1. lent). A szócikkek felépítését ezért a következőképpen alakítottuk ki: a szócikk sorszámát az angol terminus követi címszóként, ezután megadjuk a magyar terminusekvivalenciá(ka)t, végül önálló szócikk esetében a definíció, utaló szócikk esetében pedig az utalás következik. Ennek megfelelően 
a szócikkek sorrendjét - a német és a francia változattal szemben, ám az UNGEGNlistának megfelelően - az angol terminusok betürendje, azaz az eredeti angol szójegyzék szócikkeinek sorrendje szabja meg.

Az angol terminus magyar megfelelőjének, illetve megfelelőinek a megadásakor előnyben részesítettük a hagyományosan elterjedt, főként nemzeti nyelvi eredetű szakkifejezéseket; az ezek mellett sokszor inkább csak újabban jelentkező nemzetközi hátterü terminusokat zárójelben tüntettük fel a megfelelő magyar eredetü szakkifejezés mögött; pl. 01 névváltozat (= allonima); ${ }^{2} 19$ népnév (= etnonima); 27 szentnév (= hagionima); 29 víznév (= hidronima); 68 helynév (= toponima). Amennyiben a magyar nyelvben csak a nemzetközi jellegü terminus használata vált gyakorlattá, értelemszerüen ezt a megfelelést adtuk meg (pl. 16 endonima, 20 exonima, 33 makrotoponima, 35 mikrotopomina). A nemzetközi hátterü magyar terminusokat - a hasonló eredetü angol szakkifejezések alakjától függetlenül - a hazai szaknyelvben meghonosodott formájukban rögzítettük, pl. 13 denominatum = megnevezett (= denotátum). Ha az angol terminusnak pontosan megfeleltethetö magyar ekvivalenst nem találtunk, a nemzetközi hátterü terminus magyaros formáját tüntettük fel (pl. 10 koronima, 18 ergonima), illetve megfelelö magyar eredetü terminust dolgoztunk ki (pl. 09 informális név, 42 szigetnév), esetenként a két eljárást kombináltuk, pl. 34 anyanévi eredetü név (= matronimikum, metronimikon); 53 apanévi eredetü név (= patronimikum, patronimikon). Amennyiben a nemzetközi hátterü angol szakkifejezésnek megfelelö magyar elem önállóan nem, ám magyar terminusok alkotóelemeként előfordul nyelvünkben, ezt jelöltük (pl. 49 -onima utótag).

Az angol-magyar terminusekvivalenciák megítélésekor a szakkifejezések által jelölt fogalmak (szemléleti) azonosságát vettük alapul, pl. 22 first name és 24 forename = utónév (névelemek sorrendje); 21 family name = családnév (funkció), 32 last name és 64 surname $=$ vezetéknév (névelemek sorrendje). Az azonos terminusalkotó elemek révén összetartozó angol szakkifejezéseket, ahol erre mód volt, hasonló felépítésü magyar megfelelökkel törekedtünk visszaadni, pl. 67 toponomastics = helynévkutatás, helynévtan (= toponomasztika), 68 toponym = helynév (= toponima) és 69 toponymy = helynévállomány. A magyar terminusok hagyományosan kialakult alá-, fölé- és mellérendeltségi viszonyait igyekeztünk tükröztetni, megtartani (pl. 09 informális név és alkategóriája, a 43 ragadványnév; 68 helynév [= toponima] és egyes esetekben szinonimája, a 25 földrajzi név). (Magyar eredetü és nemzetközi hátterü névtani terminusaink kérdéseinek elvi vonatkozásaihoz 1 . FARKAS 2012; a magyar névtani terminusok keletkezésének és változásának tényezőihez 1. SLÍz 2012.)

Az önálló szócikkek definíciói az eredeti meghatározásokat követik tartalmilag és formailag egyaránt, azaz a jelentés megadását esetenként illusztratív példák bemutatása követi, és ha szükséges, megjegyzések alkalmazására is sor kerül. Az utaló szócikkek a jelentést megadó önálló szócikkek angol és magyar címszavát, valamint zárójelben a szócikk jegyzékbeli sorszámát közlik. Az illusztratív példák többnyire szintén az eredeti angol szövegből származnak (pl. a 09 informális név, a 31 lakossági név, a 43 ragadványnév esetében), néhol magyar példákkal is kiegészítve (pl. a 30 becenév, a 35 mikrotoponima, a 63 utcanév esetében); ám egyes terminusok kapcsán a helyes értelmezés érdekében

\footnotetext{
${ }^{2}$ A terminus előtt annak a szócikknek a sorszáma áll, amelyben a kérdéses szakkifejezés a magyar szójegyzékben megtalálható.
} 
az eredeti példáktól eltérő, de funkciójukban azoknak megfelelő magyar nevek kizárólagos alkalmazása mutatkozott célszerünek (pl. a 22 utónév esetében). Az eredeti terminusjegyzék jelentésre (pl. 69 helynévállomány, 27 szentnév [= hagionima], 52 hegynév [= oronima]), formára (pl. 34 anyanévi eredetü név [= matronimikum, metronimikon]), tulajdonnévi jellegre (pl. 19 népnév [= etnonima], 31 lakossági név), használatra (pl. 10 koronima, 14 köznevesült tulajdonnév, 68 helynév [= toponima]) vonatkozó megjegyzéseit, javaslatait megtartottuk; sőt, néhány esetben az angol, illetve a magyar terminus értelmezésének, használatának a jellemzőire utaló saját megjegyzést is beillesztettünk (pl. 22 utónév, 49 -onima [utótag]). A megjegyzéseket a definíció részének tekintettük, a szócikkekben külön egységként való megjelenítésüket nem tartottuk szükségesnek.

A magyar terminusok szerinti kereshetőséget biztosítja a magyar-angol mutató. A mutató első oszlopában a magyar terminusok szerepelnek betürendben; az összetett szakkifejezések - az UNGEGN-lista mutatójának gyakorlatát követve - elö- és utótagjuk szerint is be vannak sorolva (pl. személynévállomány és állomány, személynév-; dülőnév és név, dülö-); a szinonim terminusok minden lehetséges sorrendben elöfordulnak, a szinonimitás jelölésével; pl. allonima (= névváltozat), névváltozat (=allonima) és változat, név- (= allonima). A második oszlopban a magyar terminus(ok)nak megfelelö angol szakkifejezést találjuk. Ha a magyar terminus(ok)nak több angol nyelvü ekvivalenciája is ismeretes az ICOS-jegyzék alapján, valamennyit feltüntetjük minden alkalommal, pl. helynév (= toponima), név, hely- (= toponima), toponima (= helynév) $\rightarrow$ place name toponym. A mutató harmadik oszlopában a magyar terminus(oka)t tartalmazó önálló vagy utaló szócikkeknek a sorszámát adtuk meg.

Az angol-magyar-német-francia terminusekvivalenciákat megadó négynyelvü jegyzékben az önálló vagy utaló szócikkek címszavaiként álló, valamint a megjegyzésekben előkerülő terminusok kaptak helyet. A terminusok angol-német megfeleléseinek az azonosítása nem jelentett különösebb problémát, mivel a német szakkifejezések angol ekvivalensei a szójegyzék német változatában többnyire fel vannak tüntetve. Az angol ekvivalens nélkül felvett néhány német terminus utaló szócikk címszava, így ezeket a megfelelö, az angol terminust közlö önálló szócikk címszava mögött, zárójelben tüntettük fel a négynyelvü jegyzékben; pl. Hydronym (= Gewässername), Hypokoristikon (=Kosename). A francia terminusok angol ekvivalenseinek az azonosítását a definíciók angol és francia szójegyzékbeli szövegének, illetve az illusztratív példáknak az összevetése tette lehetővé. Ha a francia szójegyzék több, szinonim angol szakkifejezésre egyetlen francia ekvivalenciát adott meg, ezt a terminust írtuk be valamennyi kérdéses angol müszóhoz, pl. microtoponym, minor name $\rightarrow$ microtoponyme; Christian name, first name, forename, given name $\rightarrow$ prénom. Az eredeti angol glosszárium anyagához mérten többletként jelentkező egy-egy német, illetve francia szócikk címszavát pedig rövid magyarázattal ellátva, az értelmileg hozzá legközelebb eső megfelelő nyelvű terminus mellett adtuk meg, vö. német „Onym (melléknévi formája: onymisch)”; francia „onomasticien (helynevek vonatkozásában: toponymiste)”.

3. Az UNGEGN föbb törekvései. Az UNGEGN az ENSZ Gazdasági és Szociális Tanácsán (UN Economic and Social Council; ECOSOC) belül működő hét állandó szakértői testület egyike. A szervezet 1959-ben kezdte meg müködését előbb ideiglenes, majd 1973 óta állandó bizottságként. Jelenleg több mint 100 országból mintegy 400 tagja van, főként földrajztudósok, térképészek, nyelvészek, történészek, földmérők és az 
államigazgatásban dolgozó szakemberek. Az UNGEGN feladatai közé tartozik a nemzetközi helynév-standardizációs tevékenység népszerüsítése, irányítása; a földrajzi nevek egységesítésével kapcsolatos terminológiai kérdések tisztázása; a hivatalos helynévalkotással összefüggő irányelvek megfogalmazása; a latin betüs helynévírás egységes elveinek kidolgozása; a nemzeti névtestületek felállításának és hatékony müködésének ösztönzése; a már egységesített földrajzi nevek vonatkozásában a névinformációk gyüjtése, az adatok tárolása, karbantartása és terjesztése; helységnévtárak, földrajzinév-adatbázisok létrehozása; a helynév-standardizációval összefüggő oktatás biztosítása. A szakértői testület a hivatalos, írásbeli földrajzi nevek nemzetközi egységesítését az e téren elért nemzeti eredményekre építi; döntéseit, a szabványosítás gyakorlatának megfelelően, konszenzus útján hozza; az UNGEGN szervezeti felépítéséről, földrajzinév-egységesítési alapelveiröl, helynév-standardizációs modelljéről 1. BÖLCSKEI 2012a.).

Az UNGEGN a helynév-standardizáció egyes országokban való eredményes megvalósításához a kérdéskört elméleti és gyakorlati oldalról tárgyaló kézikönyvek kiadásával is hozzájárul. A Manual for the National Standardization of Geographical Names címü kiadvány (Manual 2006) egy, a földrajzi nevek nemzeti egységesítésében jó eredményeket elért tagországok által alkalmazott „legjobb gyakorlatok” alapján kialakított standardizációs modell részletes leírását tartalmazza; míg a Technical reference manual for the standardization of geographical names címü kézikönyv (Manual 2007) gyakorlati segítséget nyújt a nem betüírást alkalmazó, illetve a nem latin ábécét használó nyelvek helyneveinek latin betüs átírása, a helynévi adatok pontos nemzetközi átadása, valamint a világ országainak hivatalos angol és helyi megnevezései vonatkozásában.

3.1. Terminológiai munkálatok az UNGEGN-ben és a földrajzinév-egységesítéssel kapcsolatos szakkifejezéseket közreadó terminológiai szójegyzék. A fent említett két kézikönyv kiadását megelőzte egy, a helynév-standardizáció során gyakran használatos terminusokat összegyüjtő és definiáló szójegyzék elkészítése, amely az ENSZ hat hivatalos nyelvén (angol, arab, francia, kínai, orosz, spanyol) jelent meg, s amely a kézikönyvek terminushasználatának alapjául szolgált (UNGEGN Glossary).

E szójegyzék előzménye a H. A. G. LEWIS által szerkesztett, 1984-ben kiadott Glossary No. 330: Technical Terminology Employed in the Standardization of Geographical Names [Szójegyzék No. 330: A földrajzi nevek egységesítésében használt szakkifejezések] címü terminusgyüjtemény volt, amely 115, a témához kapcsolódó fogalom megjelölésére összesen 175 szakkifejezést sorolt fel és határozott meg az említett hat nyelven. Javított változatát Glossary No. 330/Rev² jelzés és változatlan cím alatt 1987-ben tették közzé (RAPER 2000: 194, KERFOOT 2000: 205). E terminusgyüjteménynek FÖLDI ERVIN jóvoltából magyar fordítása is készült, amely a Névtani Értesítőben jelent meg, az ENSZ földrajzinév-egységesítési tevékenységének gyakorlatát bemutató tanulmánnyal együtt (1992a, 1992b). Az UNGEGN 1989. évi 14. ülése ugyanakkor a hatnyelvü jegyzék javításának szükségességéről határozott, mivel az a téma szempontjából nem volt teljesnek ítélhető, több ismétlődést is tartalmazott, a definíciók pedig nem érintették a nem latin betüs írásrendszerek és a nem európai nyelvek sajátosságait.

Az UNGEGN ekkor egy, a helynév-standardizáció terminológiájával foglalkozó munkacsoport létrehozását kezdeményezte, az izraeli Naftali Kadmon irányításával, aki a szójegyzék megújítását célzó munkálatok vezetésére is vállalkozott. A terminológiai munkacsoport 1991-ben, az UNGEGN 15. ülésén mutatta be a készülő új szójegyzék 
első változatát, amely 336 terminust és definíciót tartalmazott angol nyelven, helynévi példái pedig már 16 nyelvből, illetve írásrendszerből származtak. 1992-ben, a földrajzi nevek egységesítésével foglalkozó hatodik ENSZ-konferencián (United Nations Conference on the Standardization of Geographical Names; UNCSGN) a résztvevők a terminológiai munkacsoport fenntartásáról döntöttek, s feladatául egy, az ENSZ hivatalos nyelvein elérhető helynév-standardizációs terminológiai szótár elkészítését, a későbbiek során pedig annak rendszeres felülvizsgálatát és karbantartását jelölték ki. A munkacsoport 1998-ban, a hetedik UNCSGN-konferencián nyújtotta be a szójegyzék újabb és bővebb változatát. A 375 terminust tartalmazó, hatnyelvü változat mint UNGEGN-dokumentum az ENSZ Gazdasági és Szociális Ügyek Főosztálya Statisztikai Részlege (UN Department of Economic and Social Affairs Statistics Division) kiadványaként 2002-ben jelent meg New Yorkban (GTSGN.). E kiadvány főszerkesztője NAFTALI KADMON volt; a szójegyzék összeállításában, fordításában pedig az UNGEGN földrajzinév-egységesítési terminológiával foglalkozó munkacsoportjának tagjai segédkeztek önkéntes alapon.

A munkacsoport további kötelezettsége maradt a szójegyzék folyamatos korszerüsítése a tudományos szemlélet, valamint a nyelv változása függvényében. Ennek jegyében született meg a 2007-ben kiadott függelék, az Addendum (AGTSGN.), amely hat, korábban már meghatározott terminus új definícióját, valamint tizenhét újonnan definiált terminust közöl angol nyelven; valamint elkészült az Addendum anyagának fordítása is az ENSZ valamennyi hivatalos nyelvére. Az UNGEGN honlapján jelenleg a 2002-es szójegyzék és a 2007-es függelék egybeszerkesztésével született 2015-ös kiadványváltozat található meg pdf formátumban (UNGEGN Glossary). (A szójegyzék és a függelék anyagának nyelvészeti szempontú áttekintését 1. BÖLCSKEI 2012b.)

A szójegyzéknek az ENSZ hat hivatalos nyelvén kiadott változatán túl több, egyéb nemzeti nyelvü adaptációja is elkészült, pl. német (JORDAN-BEINSTEIN 2011), lengyel (ŁUKASIK ford. 2014); a 2012-ben megjelent koreai kiadvány pedig az UNGEGN honlapjáról is letölthető (UNGEGN Glossary Korean).

Összességében a terminológiai munkacsoport tevékenysége egyrészt erősen kapcsolódik az UNGEGN azon felismeréséhez, hogy fö törekvéseinek sikeres megvalósításához alapvető feltétel a földrajzi nevek egységesítésével kapcsolatos szabványosított és harmonizált terminológia bevezetése, használatának támogatása (UNGEGN Brochure); másrészt összhangban áll az újabban más tudományágakban is egyre hangsúlyosabban jelentkező nemzetközi terminológiai egységesítési gyakorlattal. 2008 óta a munkacsoport, melynek jelenlegi vezetője a svéd Staffan Nyström, részben a személyi átfedéseknek köszönhetően eredményesen müködik együtt az ICOS terminológiai munkacsoportjával is (1. NYSTRÖM 2014).

3.2. Az UNGEGN-szójegyzék magyar változata. Az UNGEGN helynév-standardizációs terminológiai szójegyzékének magyar változata, pontosabban annak első verziója a Károli Gáspár Református Egyetem Magyar Nyelvtudományi Tanszékén készült el 2013-ban, projektmunka keretében (projektvezető: Bölcskei Andrea), terminológia mesterszakos hallgatók (Miklódy Dóra, Horváth Ágnes, Nagy Ilona Erzsébet, Sajermann Zsófia Szonja és Varga Julianna) bevonásával (vö. BöLCSKEI 2013a), hogy a lektorálás után a magyar nyelvü földrajzi nevek egységesítésének anyaországbeli és határon túli gyakorlatát segítse (az utóbbi kérdésről vö. SZABÓMIHÁLY 2007, 2009, 2013; CSOMORTÁNI 2014). 
Munkánk során figyelembe kellett vennünk, hogy az eredeti szójegyzék egy meglehetősen összetett terminológiai alapelv (vö. BUDIN 2001: 14-17) megvalósítására törekszik, s földrajzi és nyelvi kötöttségektől mentesen igyekszik a szakmai kommunikáció terminológiai problémáit megoldani: olyan elméleti keretet biztosít, amelyet a szakértők könnyen megoszthatnak egymással, s amelyet ki-ki a saját vagy az általa képviselt igényeknek, nyelv(ek)nek, anyanyelvnek megfelelően tovább alakíthat. A készítők - korszerü terminográfiai elveket alkalmazva (vö. CABRÉ 2003: 183) - a terminológiai egységeket ezért kognitív, nyelvi és kommunikatív összetevőik bemutatása mentén írták le. A magyar változat elkészítésekor feladatunk tehát kettős volt: meg kellett őriznünk az eredeti glosszárium szemléletét, de anyanyelvünk sajátosságaihoz, terminushasználatának gyakorlatához kellett igazítanunk annak anyagát.

Az UNGEGN-szójegyzék magyar változatának elkészítése során alkalmazott alapelvek nem térnek el az ICOS-terminuslista magyar változatának kialakítása kapcsán fent már ismertetettektől. Részletezve: az angol terminus magyar ekvivalensének, ekvivalenseinek a megadásakor a magyarosság és a nemzetközi érthetőség követelményének az összeegyeztetésére törekedtünk, ezért amennyiben létezik, a hagyományos használatú magyar eredetü müszót tüntettük fel elsődleges megfelelönek, s mellette zárójelben, egyenlőségjel után adtuk meg az azonos jelentésű nemzetközi hátterü magyar szakkifejezést, pl. 017 személynév (= antroponima), 021 kétnyelvüség (= bilingvizmus), 064 mellékjel (= diakritikus jel), 129 útnév (= hodonima). Fordított sorrenddel azokban az esetekben éltünk, amikor az idegen hátterü magyar terminus jóval gyakrabban jelentkezik a megfelelö szaknyelvi regiszterben, mint magyar eredetü megfelelöje, pl. 007 allofón (= hangváltozat), 099 firmware (= belsö vezérlöprogram), 171 ligatúra (= ikerbetü).

Amennyiben nyelvünkben csak a magyar eredetü (pl. 280 latin betüs átírás), illetve csak a nemzetközi hátterü terminusok váltak elterjedtté (pl. 047 kreol, 142 interfész), természetesen azokat írtuk be ekvivalensként. A hiányzónak vélt magyar terminusekvivalenciákat fordítás (pl. 104 full title $\rightarrow$ teljes megnevezés, 299 short form [of a name] $\rightarrow$ rövid névforma) útján kidolgozott, illetve a nemzetközi hátterü terminus magyaros formájának kialakításával létrehozott (pl. B118 geonym $\rightarrow$ geonima), esetenként a két típusú megközelítés kombinálásával megalkotott (pl. 277 retranszkripció [= kiejtés szerinti átírás visszaalakítása], 278 retranszliteráció [= betü szerinti átírás visszaalakitása]) szakkifejezésekkel pótoltuk. Az angol főnév/melléknév + fönév szerkezetü terminusok esetében, mivel ezek mögött többféle grammatikai, szemantikai viszony is meghúzódhat, sokszor célszerünek mutatkozott az angol müszónál jóval kifejtettebb magyar szakkifejezést kidolgozni a definíció tükrében, pl. 372 vowel marker = magánhangzójelölö kiegészítö írásjegy; 015 alphabetic sequence rules = betürendet meghatározó szabályok; 342 toponymic guidelines = helynév-egységesitési irányelvek.

Az angol-magyar terminusekvivalenciák azonosításakor számításba kellett vennünk, hogy az egyes nyelvek lexikálisan másként oszthatják fel a valóságot, ezért a szakkifejezések sem mindig pontos megfelelöi egymásnak (vö. KLAUDY 1997²: 117). Van példa arra, hogy egy angol terminus, a jelentés függvényében, két különböző magyar terminusekvivalenssel rendelkezik, pl. 344 toponymy = (a) helynévtan, helynévkutatás (= toponomasztika); illetve (b) helynévállomány. Más esetben két azonos jelentésü, ám formájában (részben) különböző angol szakkifejezésnek egy magyar terminusekvivalens feleltethető meg, pl. 269 proper name és 270 proper noun = tulajdonnév; 032 composite name és 033 compound name = összetett név; 185 man-made feature és 048 cultural feature = 
mesterséges alakulat; 265 place name index és 343 toponymic index = helynévmutató. Néhány alkalommal a szinonim angol terminusoknak rokon értelmű magyar terminusekvivalensei akadnak, pl. 173 linguistic area = nyelvterület és 175 linguistic region = nyelvi régió. Az is megesik, hogy egy egynemünek tekintett fogalmat jelölő angol müszónak létezik ugyan magyar megfelelője, ám ez nyelvünkben két terminus hiperonimája; ezt csak a definíció szintjén érzékeltethettük, pl. 001 acronym $\rightarrow$ mozaikszó (= akronima): a betüszó és a szóösszevonás összefoglaló megjelölése.

A szakirodalomból nyert, egymással azonos értékben használt angol és magyar terminusok időnként erősen eltérő szemléletet tükröznek, pl. 110 generic element $\rightarrow$ földrajzi köznévi elem, 112 generic term = földrajzi köznév. Találunk anyagunkban ún. „hamis barát” terminusokat is, pl. 003 allograph = allográf (= iráselem-változat, betüváltozat), nem pedig más által írott (vö. allográf végrendelet); 005 allonym = névváltozat (= allonima), nem pedig álnév; 368 vocalization = magánhangzó-jelölés, nem pedig vokalizáció. A megfelelö magyar terminus azonosításában, megalkotásában fontos szerepük lehet a definícióban foglaltaknak, pl. 092 feature, natural=alakulat, természetes: ,$\rightarrow$ Topográfiai alakulat, amelyet nem ember hozott létre, és lényegesen nem is módosított”; 093 feature, physical = alakulat, természeti: „Bármely olyan $\rightarrow$ topográfiai alakulat, amely vizuálisan észlelhető". A többféle formában is jelentkező magyar terminusok esetében a gyakrabban használatos alakot vettük fel a szójegyzékbe; pl. 364 vektoros mód, nem pedig vektormód.

Törekedtünk az eredeti terminuscsoportok megfelelő módon való visszaadására, így pl. a -gram $\rightarrow$-gram $\sim$-gramma 'jel' utótagú vagy a script $\rightarrow$ írás, írásrendszer elemet tartalmazó szakkifejezések esetében, pl. 257 phonogram $\rightarrow$ fonogramma (= hangjel), 134 ideogram $\rightarrow$ ideogramma (= képírásjel), 179 logogram $\rightarrow$ logogram (= szójel), 326 syllabogram $\rightarrow$ szillabogram (= szótagjel); illetve 061 defective alphabetic script $\rightarrow$ hiányos betüirás, 075 donor script $\rightarrow$ átadó írás, 182 logographic script $\rightarrow$ szójelölö irás, 208 multiscriptual map $\rightarrow$ több irásrendszerü térkép, 189 map script $\rightarrow$ térképi irás.

Az önálló szócikkek esetében igyekeztünk megtartani a definícióknak az eredeti szójegyzékben fellelhető értelmi és formai összefüggéseit (pl. a kapcsolódó címszavakra való szövegbeli utalások rendszere; a jelentések logikai kapcsolatait taglaló, egymást magyarázó, illetve párhuzamos megfogalmazású definíciók esetei); valamint törekedtünk arra, hogy megőrizzük a meghatározások mögött lévő szemléletet (pl. a szaktudományokban bevett meghatározásokhoz képest általánosabb vagy részletezőbb jellegü definíciók). A definíciók megfogalmazása során a megfelelő szakszókincs megismerése és alkalmazása vonatkozásában fontos tényezőnek mutatkozott bizonyos, elsősorban nyelvtudományi, földrajztudományi, térképészeti és számítástechnikai háttérismeretek megléte, illetve az ezek megszerzésére való képesség. Az utaló szócikkek a jelentést megadó önálló szócikkek angol címszavát, valamint zárójelben a szócikk jegyzékbeli sorszámát közlik a definíció helyén.

Az illusztratív névpéldák tekintetében azok jellegének és szócikkbeli szerepének megfelelöen különféle eljárásokkal éltünk. Bizonyos esetekben az angol anyagban megadott formában volt indokolt megtartani a helyneveket, pl. Kaapstad és Cape Town a 228 név, egységesitett ( = standardizált) terminus jelentését megvilágító példaként. Máskor az eredeti nyelvü helynévforma mellett zárójelben a magyar alak is megadható volt a tárgyalt jelenség bemutatására, pl. Al-Mamlakah al-Hāshimīyah al-Urdunīyah (Jordán Hásimita Királyság) a 183 teljes névforma példájaként. Néhol célszerü volt a névpéldákhoz 
szöveges magyarázatot füzni, pl. az A240 helynév (= toponima) alanyesete szócikk esetében; magyar nyelvü adatokkal szaporítani az eredeti példaanyagot, pl. a 081 exonima szócikk esetében; illetve az eltérő nyelvi sajátosságok miatt magyar példával kiváltani az eredeti kifejezést, pl. a 201 morféma szócikk esetében.

A szójegyzék magyar változatának formai sajátosságait az eredeti kiadvány nem angol nyelvű terminuslistáinak gyakorlata nyomán alakítottuk ki. A szócikkek a magyar változatban is sorszámmal kezdődnek, ezután következik címszóként az angol terminus, majd a magyar terminusekvivalenciá(k), végül pedig a definíció, illetve az utalás. A szócikkek sorrendje tehát, mint a többi, idegen nyelvű szójegyzék esetében is, az angol címszavak betürendje szerint alakul. A könnyebb kezelhetőségre törekedve az Addendumban szereplő új definíciókat adtuk meg a hat, újra definiált szakkifejezés meghatározásaként, a 2007-ben újonnan felvett terminusokat pedig a 2002-es lista megfelelő helyére illesztettük be. Az angol nyelvü szójegyzék szemléletének megfelelően a több tagból álló terminusokat első és második elemük szerint is listáztuk, fő-, illetve utaló címszóként, a hasonló módon kezelt magyar terminusekvivalensekkel együtt. Az eredeti szójegyzék angol terminushasználatra vonatkozó megjegyzéseit, mivel maguk az angol terminusok is a jegyzék részét képezik, megfelelő magyarázat kíséretében átemeltük. A magyar terminusok visszakereshetőségét a szójegyzék végén található magyar-angol betürendes mutató biztosítja. (A szójegyzék magyar változatának készítésekor alkalmazott alapelvek részletezőbb kifejtését a még lektorálás előtt álló változat vonatkozásában 1. BÖLCSKEI 2013b.).

A magyar szöveg az angol nyelvü szójegyzék alapján készült, de a magyar változatot lektorok segítségével összevetettük a francia (Vitányi Borbála), a spanyol (Tóth Mária) és az orosz (Slíz Mariann) nyelvü anyaggal is. A definíciók szakszerüségének és az angol-magyar viszonylatban megvalósított terminusharmonizáció megfelelőségének az ellenőrzésére szakembereket kértünk fel a nyelvészet (B. Papp Eszter, LEG Magyarország Zrt.; Mikesy Gábor, FÖMI), a földrajz (Tiner Tibor, MTA Csillagászati és Földtudományi Kutatóközpont Földrajztudományi Intézet), a térképészet (Márton Mátyás, ELTE Térképtudományi és Geoinformatikai Tanszék), a müszaki tudományok, a számítástechnika (Kovács László, TÉK Localizations Kft.) és a szakközgazdaság (Perger Imre, MÁV-START Zrt.) területéröl; egyeztettünk továbbá közigazgatási szakmai tanácsadóval is (Győrpál Elemér, Belügyminisztérium Önkormányzati Főosztály). A szakemberek javításait, megjegyzéseit indokolt esetben beépítettük a szövegbe, s ezt a változatot juttattuk el végső lektorálásra Földi Ervinnek (a magyar Földrajzinév-bizottság korábbi elnökének) és Pokoly Bélának (vezető tanácsadó, Földrajzinév-bizottság), akik az UNGEGN tevékenységének egykor, illetve jelenleg is aktív részeseiként alapos tudással rendelkeznek a témakört illetően (l. fent). A szójegyzék a jelenlegi formáját az általuk javasolt módosítások javának végrehajtása után nyerte el. A terminusjegyzék magyar változatának e kötetbeli megjelentetésére az ENSZ megfelelő bizottságának (Publications Board and Exhibits Committee) titkárától 2015. június 12-én kaptuk meg az engedélyt.

4. Összegzés. Mind az ICOS-jegyzék, mind pedig az UNGEGN-glosszárium magyar változatának az elkészítése során igyekeztünk ötvözni a tudományos pontosságot, a közérthetőséget, a forrásként használt dokumentumok anyagának, szemléletének tiszteletben tartását, a megfelelö magyar szaknyelvi regiszterek terminushasználatában megfigyelhető sajátosságok követését és a gyakorlati célszerüséget. A két terminusjegyzéket 
a kapcsolódó mutatókkal együtt az alábbiakban adjuk közre, abban a reményben, hogy a szakemberek, valamint a téma iránt érdeklődők számára egyaránt eredménnyel és könnyen használhatók lesznek.

\section{Hivatkozott honlapok}

AGTSGN. 2007. = KADMON, NAFTALI ed., Addendum for Glossary of Terms for the Standardization of Geographical Names. ST/ESA/STAT/SER.M/85/Add.1. United Nations, New York. https:// unstats.un.org/unsd/geoinfo/UNGEGN/docs/pubs/glossary add e.pdf

Glossary No. 330/Rev ${ }^{2}=$ Technical Terminology Employed in the Standardization of Geographical Names. ST/CS/SER.F/330/Rev.2. United Nations, 1987. http://unstats.un.org/unsd/geoinfo/ UNGEGN/docs/pubs/ST CS SER.F 330 Rev.2.pdf

GTSGN. 2002. = KADMON, NAFTALI ed., Glossary of Terms for the Standardization of Geographical Names. ST/ESA/STAT/SER.M/85. United Nations, New York. http://unstats.un.org/unsd/geoinfo/ UNGEGN/docs/glossary.pdf

Icosweb $=$ https://www.icosweb.net/drupal/

Icosweb Terminology $=\underline{\text { https://icosweb.net/drupal/terminology }}$

Jordan, Peter - Beinstein, Bernd 2011. German Glossary of Toponymic Terminology, Third Edition. Twenty-sixth UNGEGN session, Vienna. http://unstats.un.org/unsd/geoinfo/UNGEGN/ docs/26th-gegn-docs/WP/WP66_Glossary.pdf

ŁUKASIK, MAREK ford. 2014. Stownik terminów używanych przy standaryzacji nazw geograficznych. Główny Urząd Geodezji i Kartografii, Warszawa. http://ksng.gugik.gov.pl/english/wydawnictwa.php

Manual 2006. = United Nations Group of Experts on Geographical Names ed., Manual for the national standardization of geographical names. ST/ESA/STAT/SER.M/88. Economic \& Social Affairs. United Nations, New York. http://unstats.un.org/unsd/publication/seriesm/seriesm 88e.pdf

Manual 2007. = United Nations Group of Experts on Geographical Names ed., Technical reference manual for the standardization of geographical names. ST/ESA/STAT/SER.M/87. Economic \& Social Affairs. United Nations, New York. http://unstats.un.org/unsd/geoinfo/UNGEGN/docs/ pubs/UNGEGN\%20tech\%20ref\%20manual_m87_combined.pdf

UNGEGN Brochure $=$ http://unstats.un.org/unsd/geoinfo/UNGEGN/docs/pubs/UNGEGNbrochure en.pdf

UNGEGN Bulletin 35 = http://unstats.un.org/unsd/geoinfo/UNGEGN/docs/Bulletin/ungegnbulletin35.pdf

UNGEGN Glossary = KADMON, NAFTALI ed., Glossary of Terms for the Standardization of Geographical Names (Revised). http://unstats.un.org/unsd/geoinfo/UNGEGN/docs/pdf/Glossary of terms revised.pdf

UNGEGN Glossary Korean =지명 표준화를 위한 용어사전 Glossary of Terms for the Standardization of Geographical Names. National Geographic Information Institute, Republic of Korea. http://unstats.un.org/unsd/geoinfo/UNGEGN/docs/pdf/Glossary final.pdf

\section{Hivatkozott irodalom}

BÖLCSKEI ANDREA 2012a. Helynevek standardizációja: alapelvek, terminológiai kérdések a nemzetközi és a magyar gyakorlatban. Helynévtörténeti Tanulmányok 7: 85-102.

BÖlCSKEI ANDREA 2012b. A helynév-standardizáció terminológiájáról. Névtani Értesitő 34: 167-178.

BÖLCSKEI ANDREA 2013a. Az „UNGEGN Glossary of Terms for the Standardization of Geographical Names” címü terminusjegyzék magyar változatának elkészítéséről. Névtani Értesitő 35: 11-21. 
BÖLCSKEI, ANDREA 2013b. Challenges in updating the Hungarian terminology for geographical names standardization. Magyar Terminológia 6/2: 153-168. https://doi.org/10.1556/1206.2013.6.2.3

BUDIN, GERHARD 2001. A critical evaluation of the state-of-the-art of terminology theory. ITTF Journal 12/1-2: 7-23.

CABrÉ, TeResa 2003. Theories of Terminology: their description, prescription and explanation. Terminology 9/2: 163-199. https://doi.org/10.1075/term.9.2.03cab

CSOMORTÁNI MAGDOLNA 2014. A romániai magyar kisebbségi helységnév a nyelvi tervezés érdeklődési körében. Névtani Értesitö 36: 81-93.

FARKAS TAMÁS 2012. Szempontok a magyar névtani terminológia megítéléséhez. Névtani Értesitő 34: 139-148.

FARKAS TAMÁS 2015. A nemzetközi névkutatás és magyar kapcsolatai. In: FARKAS TAMÁS - SLíz MARIANN szerk., Magyar névkutatás a 21. század elején. Magyar Nyelvtudományi Társaság ELTE Magyar Nyelvtudományi és Finnugor Intézet, Budapest. 23-47.

FöLDI ERVIN 1992a. Az ENSZ földrajzinév-egységesítési tevékenysége. Névtani Értesitő 14: 21-35.

FÖLDI ERVIN 1992b. ENSZ földrajzinév-egységesítési szakkifejezések szótára. Névtani Értesitő 14: $127-138$.

Harvalí, Milan 2005. Towards a new millennium - towards a common onomastic terminology? In: Brylla, Eva - Wahlberg, Mats eds., Proceedings of the 21st International Congress of Onomastic Sciences. Uppsala 19-24 August 2002. Språk- och folkminnesinstitutet, Uppsala. 1: $160-171$.

Harvalík, Milan 2014. Towards a common onomastic terminology? The next step. In: TORT I Donada, Joan - Montagut i Montagut, Montserrat eds., Els noms en la vida quotidiana. Actes del XXIV Congrés Internacional d'ICOS sobre Ciències Onomàstiques. / Names in daily life. Proceedings of the XXIV ICOS International Congress of Onomastic Sciences. Biblioteca Tècnica De Política Lingüística 11. Generalitat de Catalunya, Barcelona. 21-25. http://www.gencat. cat/llengua/BTPL/ICOS2011/004.pdf és https://doi.org/10.2436/15.8040.01.4

Kerfoot, HeLen 2000. Wien or Vienna; Kalaallit Nunaat, Grønland or Greenland? Recent work and directions in geographical names standardization through the United Nations. Onoma 35: 199-213.

KLAUDY KINGA $1997^{3}$. A forditás elmélete és gyakorlata. Angol, német, francia, orosz forditástechnikai példatárral. 3., átdolgozott, bővített kiadás. Scholastica, Budapest.

NYSTRÖM, STAFFAN 2014. The terminological work of UNGEGN and ICOS - a presentation and a comparison. In: TORT I DONADA, JOAN - MONTAGUT I MONTAGUt, MONTSERRAT eds., Els noms en la vida quotidiana. Actes del XXIV Congrés Internacional d'ICOS sobre Ciències Onomàstiques. / Names in daily life. Proceedings of the XXIV ICOS International Congress of Onomastic Sciences. Biblioteca Tècnica De Política Lingüística 11. Generalitat de Catalunya, Barcelona. 52-57. http://www.gencat.cat/llengua/BTPL/ICOS2011/008.pdf\%20 és https://doi.org/ $\underline{10.2436 / 15.8040 .01 .8}$

RAPER, PETER E. 2000. Introduction to standardization of geographical names. Onoma 35: 187-198. https://doi.org/10.2143/ONO.35.0.574374

SLíz MARIANN 2012. Terminusok keletkezése és változása. Névtani Értesitő 34: 149-156.

SZABÓMihÁLy Gizella 2007. Magyar neve? Szlovákiai magyar helységnevek standardizációs problémái. Névtani Értesitö 29: 189-200.

SZABÓMIHÁLY GiZELLA 2009. A határon túli magyar helynevek standardizációs kérdései. Korunk 3/5: 95-99. 
SZABÓMIHÁLy GiZELla 2013. A szlovákiai magyar helységnevek standardizálásakor alkalmazott elvek. In: BAUKO JÁNOS - BENYOVSZKY KRISZTIÁN szerk., A tulajdonnevek a forditás és a kétnyelvüség kontextusában. Konstantin Filozófus Egyetem Közép-európai Tanulmányok Kara, Nyitra. 54-67.

BÖLCSKEI ANDREA ORCID: 0000-0003-2628-5297

KRE Károli Gáspár Református Egyetem Magyar Nyelv-, Irodalom- és Kultúratudományi Intézet Budapest 

Studies 

BöLCSKEI-FARKAS-SLíz eds., Magyar és nemzetközi névtani terminológia. Hungarian and International Onomastic Terminology. Uppsala-Budapest: International Council of Onomastic Sciences - Magyar Nyelvtudományi Társaság, 2017. 65-84. DOI: $10.26546 / 5061110.9$

\section{Terminological studies in International and Hungarian Onomastics}

1. Introduction. The paper examines the history of terminological studies in onomastics, how its terminology was formed through the work of scholars, and the results of these studies. The first section of the paper offers an account of international terminological work in onomastics. These points review the various glossaries of onomastic terminology (point 2) as well as the major terminological projects (point 3 ) in the field of onomastic studies. The more voluminous second part of the paper provides a similar overview of Hungarian work processes in the terminology of onomastics. It enumerates initiatives that aimed to create a comprehensive and organised terminology for Hungarian onomastics (point 4) while bringing certain Hungarian studies on terminological questions to light (point 5). The final section (point 6) of the paper draws parallels and illuminates connections between native language terminologies (in this case Hungarian) and international terminological work processes.

2. International studies on onomastic terminology. The work of several scholars from a variety of countries has led to the publication of several mono- and multilingual term lists and glossaries. A brief summary of these publications is provided below.

2.1. German and Slavic onomastics pioneered organised terminological work. The first glossaries of terms were published in German (WITKOWSKI 1964), and on the terminology of certain Slavic languages (Ukrainian: NIMCHUK 1966; Sorbian [or Lusatian]: PETR 1969; later, Russian: PODOL'SKAJA 1978 and 1988). Through the international cooperation of researchers, and to ease joint projects, comparative lists of German and Slavic terminologies were compiled. The first was Základní soustava a terminologie slovanské onomastiky (known in German as Grundsystem und Terminologie der slawischen Onomastik) published in 1973 (SvOBODA et al. 1973), which was followed by Osnoven sistem i terminologija na slovenskata onomastika (known in other languages as Osnovnaja sistema i terminologija slavjanskoj onomastiki. Grundsystem und Terminologie der slawischen Onomastik) a decade later (BEZLAJ et al. 1983). A newer German glossary of terms has since been completed (WALTHER 1998). Similar glossaries have also been published in several Slavic languages. (E.g. in Ukrainian as an in-print terminological dictionary: BUCHKO-TKACHOVA 2012; in Polish, as a digital term list: GAŁKOWSKI 2012. For a collection of several Slavic languages see RZETELSKA-FELESZKO et al. eds. 2002-2003. 2: 567-602. Further Slavic glossaries are currently under production.)

Onomasticians from Northern Europe have also compiled glossaries of onomastic terms in their native languages (KIVINIEMI et al. 1974, SCHMIDT 1981). As did speakers of the major Uralic languages except for Hungarian: the Finnish terminology was 
published together with the Swedish (in KIVINIEMI et al. 1974), followed later by the Estonian (HENNO-PÄLL 2003).

Glossaries on the (American) English (SMITH 1967, RoOM 1996), and (Canadian) French (DORION-POIRIER 1975) terminologies of onomastics have also been published. However, similar works on onomastic terminology are yet to be published in many major languages, for example Italian (cf. GAŁKOWSKI 2010; but see the Italian-Hungarian bilingual glossary of FÁBIÁN 2001, mentioned in more detail below).

The importance of the glossaries compiled by the United Nations Group of Experts on Geographical Names (UNGEGN) and the International Council of Onomastic Sciences (ICOS) must be stressed as these are intended for international use. (The two glossaries are examined in detail below.)

2.2. Many terms that were incorporated in term lists and glossaries of onomastic terminology have become accepted norms in their respective languages over the past decades. However, there is notable demand, and intent, for the preparation of newer glossaries, as interest in the theoretic and practical problems of onomastic terminology has not dwindled. For example, the Slovak Onomastic Commission of the L. Štur Linguistic Institute of the Slovak Academy of Sciences has begun work on a systematic digital database of onomastic terminology with international cooperation. This database will provide several types of information regarding a certain term, including its equivalents in other languages. The need for a revised and augmented version of the multilingual Osnoven sistem $i$ terminologija na slovenskata onomastika (German-Slavic) dictionary (BEZLAJ et al. 1983) was also stressed a few years ago (cf. HARVALÍK 2007).

Recent synthetic works in national or international onomastics regularly approach the difficulties of onomastic terminology in some form. Either as recurring sections of successive thematic chapters (e.g. BRENDLER-BRENDLER Hrsg. 2004), as separate chapters (e.g. WITKOWSKI 1995, KALETA 1998), or a combination of these two methods (e.g. MARCATO 2009: 10-13 and passim), or as terminological appendices to the volumes (RZETELSKA-FELESZKO et al. eds. 2002-2003. 1: 81-94, 2: 567-602).

Interest in the subject is also indicated by how separate terminological sessions were added to three of the international triennial onomastic congresses (Pisa, 2005; Toronto, 2008; Barcelona, 2011) organised by the ICOS. It is also at these conferences that the ICOS Terminological Group holds its meetings.

The general, theoretic and methodological aspects of national or international onomastic terminology have been examined and re-examined in a large number of studies in past years. A similar number of papers have reviewed single questions, or single terms in great detail. (For the most relevant literature on the subject see the Lists of Key Onomastic Terms, published on the website of the ICOS.)

3. International work processes in onomastic terminology. Cooperation between scholars over political and lingual borders - especially more organised initiatives - have naturally drawn attention to the problems of onomastic terminology and the questions faced by any effort to harmonise it. This development has been governed by a series of practical decisions, initiatives and work on an international scale. 
3.1. Following the first conference on Slavic onomastics, held in 1959, the Commission of Slavic Onomastics of the International Committee of Slavists was formed. One of the four subcommittees created was the Terminological Subcommittee (WITKOWSKI 1995: 290). In cooperation with the Institute for Slavic Studies of the German Academy of Sciences it was this subcommittee that compiled the first glossary of onomastic terminology - containing ca. 600 terms - mentioned above (WITKOWSKI 1964). The committee also played an important role in later terminological research (for more on the Slavic terminology of onomastics see BAUKO 2015c: 254-256).

In Northern-European countries the NORNA - which was founded in 1979 and oversees the onomastic cooperation of Northern-European countries - also provided a good example of the importance of onomastic terminology. The first symposium organised by the NORNA was centred around the problems of onomastic terminology and the topic also resurfaced at later symposiums (GYÖRFFY 2007: 250).

3.2. In 1959 the United Nations created - under a different name at the time - the United Nations Group of Experts on Geographical Names (UNGEGN). The UNGEGN first published a glossary, containing the terms used in geographical names standardization in 1984, of which a reviewed version was released in 1987. The document was published in the six official languages of the UN. However, due to the deficiencies of the original glossary calls for the formation of a terminological working group surfaced by 1989. The resulting revised version of the glossary of terms, written under the direction of NAFTALI KADMON, contains nearly 400 entries connected to present day practices in geographical names standardization, and was also published in the six official languages of the organization in 2002 (Glossary of Terms for the Standarization of Geographical Names). The latter document has since been augmented by an Addendum, and has also been translated to other languages. The working group is tasked with the continuous maintenance and revision of the glossary. (For more on this subject see BÖLCSKEI 2017, in current volume. The cited documents are retrievable from the UNGEGN website.)

The international standardization of geographical names is a process in which several international organisations are involved, and naturally has many terminological aspects. An example of this is the standardization of undersea feature names. The document containing the defining principles and guides to this has been published by the International Hydrographic Organization in several editions and languages (cf. MÁRTON 2012: 184-192).

3.3. At the 2002 international onomastic congress in Uppsala MiLAN HARVALíK proposed the creation of a terminology workgroup within the International Council of Onomastic Sciences (cf. HARVALÍK 2005). The Terminology Group was formed in 2004 and compiled a basic term list containing definitions and examples through the cooperation of scholars from different countries and schools of onomastics. The glossary was published online in the three official languages of the ICOS: English (the original procedural language), German and French. The initial lists were first presented at the 2005 ICOS congress in Pisa, and following further work, a revised version was completed for the 2011 congress in Barcelona. The present lists contain the definitions of about 70 items (Lists of Key Onomastic Terms). The glossaries are retrievable from the ICOS 
website. (For more on this subject see HARVALíK 2014: 21-22, and BÖLCSKEI 2017, in current volume.)

The ICOS Terminology Group aimed to cooperate with a wide range of onomasticians. Following its creation, it approached a number of scholars from different countries with a short questionnaire regarding the general problems of the field and published their answers, as well as the general conclusions drawn (HARVALÍK-CAFFARELLI 2007). The survey illustrated how scholars of every language face a series of - in part similar, in part different - questions and difficulties within onomastic terminology. Following the completion of the above mentioned glossary the Terminology Group has broadened its goals and increased its subgroups. The aim of these is to make the glossary accessible to further languages and cultures through translation, and also to examine the terminology of the various fields of onomastics in more detail.

3.4. The members of the ICOS and the UNGEGN versed in the terminological questions of onomastics formed a joint terminological committee following an agreement at the Toronto congress of the ICOS in 2008. The respective glossaries of the two organisations - as is to be expected - differ in certain regards, however a number of these differences could be lessened through cooperation. (In more detail see NYSTRÖM 2014, cf. also VASILEVA 2014.) The organised collaboration of these two international organisations - which is aided by several personal connections - can only be seen as profitable for all concerned parties.

3.5. There have been few examples of either the UNGEGN or the ICOS glossaries of terms being translated. The Hungarian versions of these glossaries are published in the present volume, in-print and digitally.

4. Endeavours for the comprehensive organisation and publication of the Hungarian terminology of onomastics. A number of sporadic papers have discussed the characteristics of, or certain terms of Hungarian onomastic terminology in the past. However, only in the 1970s - in one of the most dynamic periods of Hungarian onomastics - did an in-depth and concise debate begin on its terminology. The initiative - like so many others - was spearheaded by MIHÁLY HAJDÚ, who later became the leading organisational figure of Hungarian onomastic studies. (See his academic memoir: HAJDÚ 2010: $24-26$.

4.1. The opening statement of this initiative was written in 1974 (Introduction to a Debate on Onomastic Terms; HAJDÚ 1974a) and distributed as a copied manuscript. Its content was discussed at a meeting of concerned scholars while others submitted their opinions to the author in writing. Based on these recommendations a new version was compiled in which changes to content and style were made. (This was unavoidable as the original document had been written to open the debate.) The revised document (HAJDÚ 1974b) was later submitted to the - then still active - Onomastic Committee of the Hungarian Academy of Sciences.

The main principles of the above-mentioned initiative were: to achieve a certain level of standardization (while maintaining the possibility of stylistic or practical synonymy); to uphold traditional terms (as opposed to theoretically backed terminological modernisation); 
to diffuse the use of practical, shorter, meaningful and suffixable terms. Following the general introduction, the initiative contained several synonymous lists, asking peers to choose the most relevant term from each. Further difficulties, not handled as terminological questions, were seen as unsolvable until a series of academic articles examined them in detail.

The final section of the document presented the idea of a Hungarian onomastic encyclopedia which would also have contained entries on the terminology of the field. The volume - which would have been edited by MIHÁLY HAJDÚ and ANDRÁs MEZÖ - would have followed the principles below: the collection of every term or periphrasis ever used in Hungarian onomastics; the creation of new terms if needed; the inclusion of synonymous terms (and terms to be avoided) with reference to preferred phrases; the analysis of certain terms as part of larger entries. The planned dictionary would have contained entries for three or four thousand terms and phrases. As a sample list of lexicological headwords in the original document illustrated, the goal of the planned volume was more similar to that of an encyclopaedia than of a dictionary. (Cf. also the sample list of headwords connected to by-names: HAJDÚ 2010: 25.)

The Onomastic Committee of the Academy discussed the proposal the following year and initially deemed it worthy of support. However, not much later the committee itself was disbanded following the reorganisation of the Academy, thus the project was stalled.

4.2. The question was revisited a few years later when the Névtani Értesitö, the periodical of Hungarian onomastic studies entered circulation in 1979. The editor of the journal, MIHÁLY HAJDÚ, published a slightly revised version of his pioneering debate article in the first issue (HAJDÚ 1979). The journal then published a number of responses and opinions - from onomasticians of different generations - the same year (Névtani Értesitö 1979. 2: 28-34, 1980. 3: 56-60). The professional reviewer of the first volumes of the journal also added his thoughts on several terms listed (KÁLMÁN 1982: 502-503). By then reviews of some of the glossaries of terms published in other languages were available in Hungarian linguistic journals (of the German, Finnish-Swedish, and Russian respectively: FEHÉRTÓI 1966, MIZSER 1979, UDVARI 1981).

Nevertheless, the promising revival of the subject did not last long, as at the time of other large linguistic projects the question remained slightly peripheral, while its supporters were distracted by other professional tasks. Furthermore, it seems that despite these efforts, such a concise and systematic review of Hungarian onomastic terminology was not backed strongly enough by the researchers of the field (HAJDÚ 2010: 26, cf. HOFFMANN 2003: 54).

4.3. The following attempt to summarise Hungarian onomastic terminology was made two decades later, in the first years of the new millennium. The practical bilingual (English-Hungarian) glossary compiled by JUDIT SZILVIA VÁRNAI was a preparatory auxiliary collection to aid a larger project connecting many fields of linguistics (VÁRNAI ed. n.d.). The simple 172-item glossary which was published online was based on the translation of the then current volume (2. History of the Study of Toponyms in the Uralian Languages. Debrecen, 2002) of the Onomastica Uralica series edited in Hungary, but published in English and Russian. (This practical connection to the volume may be the reason for the thematic bias towards toponomastics apparent in the glossary.) The 
introduction written to the online version of the bilingual glossary claims that unpublished sections of the term list also contain additional information (short definitions, notes, academic references, abbreviations, information on word class, cross-references). Furthermore, it indicated continuous work on the project. However, this initiative also stalled, and further work never saw publication, nor did any of its auxiliary work processes.

From a thematic and chronological point of view a published Italian-Hungarian glossary of onomastic terms must also be mentioned here (FÁBIÁN 2001). It contains the Italian definitions of Italian headwords as entries, with corresponding Hungarian terms and examples from both languages. The compilation was created for Hungarian students of Italian, and published as an appendix to a textbook containing a broad selection of Italian onomastic articles.

The above mentioned bilingual term lists were all organised - following the order of the foreign terms - to aid the translation and interpretation of foreign onomastic research in Hungarian. Inverse lists, however, with terms ordered according to their Hungarian alphabetical order were not published alongside these.

4.4. Later proposals also stressed the importance, and examined the possible guidelines of the creation of a dictionary of Hungarian onomastic terminology. Papers presented at onomastic conferences over the following years attempted to draw conclusions regarding questions and difficulties that had already been identified (JUHÁSZ 2004: 165-166, FARKAS 2008: 339-340). However, these individual initiatives were not followed by organised research and no actual steps were made. Research into the terminology of onomastics was renewed through the cooperation of a group of scholars (Andrea Bölcskei, Mariann Slíz and Tamás Farkas), inspired by the international work done in onomastic terminology, and the need for the harmonisation of the Hungarian and the international terminology of the field. They formed the Hungarian subgroup of the ICOS Terminology Group in 2011.

Their albeit informal, but consciously organised project has led to advances regarding the Hungarian terminology of onomastics. An overview of the history and current state of terminological research in Hungarian and international onomastics was published (FARKAS 2011). A workshop entitled Onomastics and Terminology was held in 2012 and invigorated new research into the field through a series of papers and a roundtable discussion. These papers (HOFFMANN 2012, FARKAS 2012, SLíz 2012, BÖLCSKEI 2012, BAUKO 2012) and a summary of the discussion (cf. BÖLCSKEI-FÓRIS 2012) were published in the same year in the Hungarian onomastic journal, Névtani Értesitö. Furthermore, over the past years certain general and thematic problems and questions of Hungarian onomastic terminology have been brought to the surface, at times directly as a result of the terminological work being carried out, or at others in connection to onomastic research on a broader scale. (Connected research and its topics are detailed below.)

It was in connection with the formation of this working group that work began on the Hungarian version of the Glossary of Terms for the Standarization of Geographical Names (cf. BÖLCSKEI 2013a), as did similar processes - also under the supervision of ANDREA BÖLCSKEI - to translate the Lists of Key Onomastic Terms. (For more detail on these projects see BÖLCSKEI 2017, in current volume). Plans were also drawn for a comprehensive terminological dictionary of Hungarian onomastics, its preparation and defining principles (FARKAS 2013). However, the research project in which these plans were 
outlined did not receive funding. Despite this setback research already underway has continued and the Hungarian versions of the two major international glossaries have been completed. The current bilingual volume, which contains the two glossaries of terms and attached studies, is also the result of this academic cooperation.

4.5. A comprehensive, in-depth and systematic dictionary of onomastic terminology is still missing from the list of Hungarian onomastic reference books. Let it suffice to quote two of the most prominent figures of Hungarian onomastics regarding this deficiency (translated from Hungarian). MIHÁLY HAJDÚ believed that "the standardization of onomastic terminology is one of the most important questions of our time" (HAJDÚ 2011: 345). While this remark may be slightly over-zealous it is certain that - as ISTVÁN HOFFMAN stated - "a volume which collected and defined the terms used in onomastics would aid the transparency and homogenisation of the field, even if aimed to be merely informative and not norm-defining" (HOFFMANN 2003: 55). These views are coherent with the principles expressed in the recent plans of such a dictionary mentioned above.

Thus, the creation of a Hungarian list, glossary or dictionary of onomastic terms which also takes international terminology into consideration - is a task still to be completed by Hungarian scholars of the field. Work in this direction would not only be useful in Hungarian and international onomastics but facilitate professional discourse and cooperation between many scientific and academic disciplines (cf. FARKAS 2013: 445).

5. Questions regarding the terminology of onomastics in Hungarian scholarly literature. The sections below summarise onomastic articles that address the general questions of terminological issues in onomastics, and offer an overview of papers regarding the terminology of the various subfields of Hungarian onomastic studies.

5.1. Comparatively few papers have been published on the general difficulties and problems - which are thus not focused on certain subfields - faced by the Hungarian terminology of onomastics. First of all, papers calling for the systematic and comprehensive processing of terminology may be listed here (see above for more detail). Others that be should mentioned here are those that examine terminology from a theoretic point of view, concentrating on its most problematic features and listing examples from onomastic studies. Articles of the latter type have mainly been written in the recent past and direct research towards certain thematic questions: what defines a term (SLÍz 2012); connections between theory and terminology (HOFFMANN 2012); reasons behind the formation of terms, factors influencing changes in terminology and the consequences of these changes (SLÍZ 2012); terminological deficiencies (FARKAS 2012, SLíz 2014); semantic questions and difficulties in general and the use of terminologies (FARKAS 2012, SLÍZ 2014); conflicts between terms of international (foreign) origin and traditional Hungarian terms (FARKAS 2012, SLÍz 2014); questions posed by the harmonisation and standardization of terminology (BÖLCSKEI 2012, 2017); comparisons of the onomastic terminology of the Hungarian and other languages (BAUKO 2012, SLíz 2014). These questions, and the results of research into them have also - in part - been published in foreign languages: the general state, characteristics and questions of Hungarian onomastic terminology (FARKAS 2014b); the results of the comparison of Slavic and Hungarian 
onomastic terminology (BAUKO 2015c); and the difficulties faced in the translation of the UNGEGN glossary of terms (BÖLCSKEI 2013b).

The terminology of onomastics was also given some attention in a monograph on the history of Hungarian place name studies (HOFFMANN 2003: 53-55), as well as in a review of the recent past and current state of Hungarian onomastics (SLÍZ 2015: 101-103). However, terminological aspects are most common in studies that concentrate on certain thematic units, or subfields of onomastics. Comprehensive studies, monographs, and papers on various topics of onomastics are at times even forced to answer, or clear terminological difficulties.

5.2. The following points will attempt to provide a summary of the most typical subjects and terminological problems in Hungarian onomastics. As the current study does not allow for an in-depth introduction of all concerned papers, research from the recent past has been prioritised, as these also provide information on earlier research into their respective fields.

5.2.1. In the formative period (or revival) of Hungarian onomastics, indicating the separation of the field, the Hungarian term for the discipline itself was given much attention (PAPP 1955: 258, BENKÖ 1960, MIKESY 1960). It was time that eventually settled this debate as a number of terms remain in use to the present day as synonyms: névtan 'name studies', névkutatás 'name research', névtudomány 'name science', and onomasztika 'onomastics'; while others did not become common in academic and scientific discourse (cf. HOFFMANN 2012: 127-128).

5.2.2. One of the most common and problematic points of Hungarian onomastic terminology was the use of helynév 'place name' or földrajzi név 'geographical name'. The question has been revisited multiple times with recurring arguments and criticism. Both terms are in use to the present day and choosing one over the other is a point of personal preference, or the traditions of certain scientific fields. (For more detail see HoFFMANN 2003: 53-55, 2012: 128-130.) It should be noted that the name of the disciple itself: helynévtan 'place name studies' or helynévkutatás 'place name research', and other elements of its specialised terminology - due to natural diversity and different theoretical approaches - did not draw much attention (for a detailed overview see HOFFMANN 2012: 130-132).

The creation of a new model for the analysis of place names (HOFFMANN 1993, 1999), however, brought terminological changes to light, as did later studies based on this categorization (cf. HOFFMANN 2012: 133-135). Furthermore, as the HOFFMANN place name typology model proved effective in (and adaptable to) the categorization of other types of proper names as well (cf. HoFFMANN 2007: 7-8), the terminology it introduced became known and used in other fields of Hungarian onomastics.

The terminology of the international standardization of geographical names and its translation to Hungarian (examined above) is a unique aspect of this field (for more detail on the question see BöLCSKEI 2017, in current volume). The goals of this terminology are to harmonise the terms used in different languages, to create missing terms and to define existing terms in detail. (On the terms used to denote the standardization of geographical names see BÖLCSKEI 2012: 176.) It is well known that interpreting one 
single term can lead to many theoretical and practical difficulties; an especially illustrative example of this, from the field of international geographical name standardization was the case of exonym (in Hungarian: exonima; cf. POKOLY 2013, POKOLY-BÖLCSKEIMIKESY 2015). Also, the use of standard név 'standard name' or standard névváltozat 'standard name form' itself presents terminological difficulties (cf. GYŐRFFY 2012).

5.2.3. Terms denoting certain types of anthroponyms proved to be the most problematic in Hungarian onomastic terminology. This is a result of the fact that terms originating from everyday experiences and spoken Hungarian are often insufficient or problematic in professional studies of the subject. This in turn is a result of their transparent general use as common nouns, the perspective they take, and changes in the lingualcultural context of the community. Furthermore, the family name + given name order used in the Hungarian language itself leads to several terminological difficulties when translating between Hungarian and other languages (cf. terms like first name, last name etc.). This topic illustrates the difficulties and inadequacies of terms of Hungarian origin from the viewpoint of onomastic theory and historical onomastics especially well (FARKAS 2014b: 17-18).

Attention was mainly drawn to the difficulties of term use in works attempting to provide a comprehensive and methodological overview of the Hungarian anthroponymic system. KATALIN J. SOLTÉSz in her substantial monograph on name theory (1979) attempted - largely unsuccessfully - to bring terminological changes into use on many points (for its review see HAJDÚ 1981: 109-110). While MIHÁLY HAJDÚ was always open to innovation, in this case he preferred a different approach: his attempt to clarify the terminological difficulties of the field in his reference work on personal names was centred around reviewing the possibilities, and choosing one of the terms already in use (HAJDÚ 2003: 151-153, 347, 638, 732; cf. its review which emphasised his methodological approach to terminology: B. GERGELY 2007: 253-255). It would be useful to review the terminology of the field to ease interdisciplinary work (cf. for example a contrastive study on the terminology of onomastics and name law: SLíz, in press). Furthermore, a new typology of anthroponyms devised by ISTVÁN HOFFMANN (2008, also cf. HOFFMANNТо́тH 2015) automatically lead to the formation of new terms in Hungarian anthroponomastics (even though the original goal was only to offer possible terms for certain elements, cf. HOFFMANN 2008: 10, $1^{\text {st }}$ footnote). Further research into the typology of anthroponyms may yet bring further changes in the terminology used in their study (cf. SZENTGYÖRGYI 2016).

Clarifying Hungarian anthroponomastic terminology is a current question for scholars of much researched historical personal name types (in detail see SLíz 2010), and also of barely researched other, "substitute" names (helyettesito" nevek, to use the disputable term of J. SOLTÉSZ 1979: 59; cf. also HAJDÚ 2006). A newly formed name type, online nicknames also brought new terms into scholarly discourse (cf. RAÁTZ 1999: 263, 2011: 184-185).

Naturally, questions regarding the terminology of anthroponomastics reach beyond simply denoting certain name types. Personal name, and especially family name changes, for example, were examined in great detail in connection with a targeted research project. A result of this was an analysis of the (surprisingly large) historical and present day terminology, the differences in the common usage and technical usage of words in the field (FARKAS 2008), as well as the proposal of an innovative typology for personal 
name changes and the connected terminology (HAJDÚ 2009, VÖRÖS 2009). However, the concrete topic, when placed into the broader framework of a general theoretical model (FARKAS 2015b, cf. FARKAS 2016), could only become describable through different terms known from earlier works (cf. HOFFMANN 1993, 1999; also TÓTH, V. 2008; N. FODOR 2010: 115-120).

5.2.4. Other name types besides toponyms and anthroponyms have cultivated much less interest in Hungarian onomastics. The lack of theoretical work on certain topics is often illustrated by terminological deficiencies, too, such as the lack of an equivalent term for the internationally accepted chrematonym. Terminological innovation in such fields depends on in-depth research into smaller aspects (e.g. on the names of human made structures, buildings, and institutions; see HÁRI 2010).

On the other hand, terminological detail has become more and more common in literary onomastics in past years. The ground-breaking monograph entitled Az irodalmi névadás [Literary name giving] by MIKLÓs KOVALOVSZKY (1934) had a lasting effect on the terminology of the field. Thus, clarifying the differences of irói névadás 'authorial name giving' and irodalmi névadás 'literary name giving' was seen as a relevant task not only half a century ago, but also in the recent past (MIKESY 1959; KOROMPAY 2011; T. SOMOGYI 2015: 208; TÓTH, L. 2015: 203-206; VÁCZINÉ TAKÁCS 2016: 9-18). The comprehensive term - introduced in part to replace the terms mentioned above irodalmi névtan 'literary name studies' is itself a rather new term in Hungarian academic writing (cf. TÓTH, L. 2015: 206; VÁCZINÉ TAKÁCS 2016: 17). Recent articles have called for a review of the terms currently used - originating from KOVALOVSZKY (1934) and earlier, classical works - to denote the different types of proper names used in literary works (cf. TÓTH, L. 2015; VÁCZINÉ TAKÁCS 2016). Recently completed, and in-work doctoral dissertations have achieved, and indicate, quick progress in this regard.

5.2.5. Onomastic studies connected to other dimensions of language use (temporality, space, social and cultural aspects) represent further subfields in the discipline of onomastics. The most traditional of these is historical onomastics, the name of which has always been beyond question: történeti névtan 'historical name studies', or névtörténet 'name history'. The name of the newest subfield, socioonomastics has also been widely accepted as szocioonomasztika 'socio-onomastics', or névszociológia 'name sociology'. These terms are the onomastic equivalents of the generally used Hungarian terms for the respective fields of linguistic studies, i.e. historical linguistics and sociolinguistics (cf. FARKAS 2014a, with emphasis 14-17). The term to denote research into geographical distribution of onomastic phenomena, however, has been much debated in the past decades, mainly by scholars also involved in dialectological studies (e.g. ÖRDÖG 1989: 29, 1991, 2010; HAJDÚ 2002; JUHÁSZ 2004: 166-169, 2010: 31; for a more recent summary, see FARKAS 2014a: 15, and for a critical review, see N. FODOR 2014: 24-27). At the present the most common term for the discipline seems to be névföldrajz 'name geography', the onomastic equivalent of nyelvföldrajz 'language geography'.

6. Native language onomastic terminology in the context of international onomastics. This final section will focus on the interrelation and connections between Hungarian and international onomastic terminology and work within the field, and how 
native language work and research can be treated in an increasingly international academic and scientific field (cf. FARKAS 2015a: 33-41).

6.1. The terminology of onomastics in Hungarian is characterised by a high number of native terms, next to which terms of an international origin are less typical (FARKAS 2014b: 15-17, SLÍz 2014: 149-252). International terms are rarely borrowed directly and also rarely entice terminological innovation in Hungarian. (For the latter cf. the terms used by JÁN BAUKO, based on terms common in international onomastics, but unusual in Hungarian name studies: gasztroantroponima, orohodonima; cf. BAUKO 2015a: 76, 127). However, it should also be noted that certain traditional Hungarian terms often indicate a foreign - usually German - influence, or may have been formed through direct translation. The terms névkutatás 'name research' (cf. Namenforschung) and helynév 'place name' (cf. Ortsname) are also examples of such.

Besides the above, in some cases unique terms of Hungarian onomastics must also be translated to other languages. The terms used in foreign language articles introducing the theoretical models devised by ISTVÁN HOFFMANN are examples of these challenges (see e.g. HOFFMANN 1993: 153-162; TÓTH, V. 2005; HOFFMANN-TÓTH 2015).

6.2. Studies published on the terminologies of other languages, and activities in the standardization of international onomastic terminology may prove fruitful for Hungarian onomastics. Papers examining certain Hungarian terminological questions have at times been written with an outlook on the results and difficulties of the onomastic terminology of other languages. This has proven profitable not only in largely unresearched fields, but also regarding traditional and newer terms as well (e.g. cf. MIKESY 1960; HAJDÚ 2003: 151-153; VINCZE 2004: 187-188; FARKAS 2008: 336; RAÁTZ 2008: 444; BÖLCSKEI 2010: 84-85; HÁRI 2010: 102-103; TÓTH, L. 2015). There are also a few examples of studies comparing aspects of international and Hungarian onomastic terminology (a methodological comparison of the Hungarian and Slovakian/Slavic terminologies: BAUKO 2015c; on a narrower topic, Finnish and Hungarian: TAKÁCS, in press).

Publishing the results of Hungarian terminological research in the international scene is an important task. A number of studies written in foreign languages detailing certain questions and characteristics of Hungarian onomastic terminology - as detailed above have been published in the recent past (BÖLCSKEI 2013b, FARKAS 2014b, BAUKO 2015c). The current volume, containing the Hungarian version of the ICOS and UNGEGN glossaries, is itself a bilingual publication in English and Hungarian.

6.3. In past years Hungarian researchers have also begun to work within the ICOS Terminology Group. While there is also a Slovakian Hungarian scholar involved in the project aimed at building a digital terminology database organised by the Slovak Onomastic Commission, in which current plans hope to include Hungarian terms as well (BAUKO 2015b: 73).

A few bilingual term lists of Hungarian onomastics have been published before the current versions of the ICOS and UNGEGN glossaries (English-Hungarian: VÁRNAI ed. n.d., Italian-Hungarian: FÁBIÁN 2001). It should also be noted that the earlier version of the UNGEGN glossary of terms also had a Hungarian translation (FÖLDI 1992), as did glossaries on the terminology of undersea feature names (FÖLDI 1979, MÁRTON-DUTKÓ 
eds. 2003: 17-30, reprinted in MÁRTON 2012: 278-279, 305-318; on their historical background see MÁRTON 2012: 184-192).

6.4. Published works such as those enumerated above facilitate cooperation between Hungarian, and international onomastics (and other concerned disciplines), which would be impossible without clear-cut terminological connections. Common interest in international onomastics and its terminology is not only important, due to the theoretical advances made within it. It is the basic connection of a primarily native language - albeit one with an international scope and many international connections - onomastic community with its international counterpart.

\section{Internet Resources}

ICOS website $=\underline{\text { https: } / / \text { www.icosweb.net/drupal } /}$

ICOS terminology $=\underline{\text { https: } / / \text { icosweb.net/drupal/terminology }}$

UNGEGN website $=$ https://unstats.un.org/unsd/geoinfo/UNGEGN/

UNGEGN terminology = https://unstats.un.org/unsd/geoinfo/UNGEGN/publications.html

\section{Bibliography}

B. Gergely, Piroska 2007. Hajdú Mihály: Általános és magyar névtan [Mihály Hajdú: General and Hungarian Onomastics. (Review)]. Magyar Nyelvör 131: 253-258.

BAUKO, JÁNOS [JÁN] 2009. Ragadványnév-vizsgálatok kétnyelvü környezetben. (Négy szlovákiai magyar település ragadványnévrendszere) [Investigation of Nicknames in a Bilingual Environment. (The System of Nicknames in Four Hungarian Settlements in Slovakia)]. Nitra; Budapest: Univerzita Konštantína Filozofa v Nitre Fakulta stredoeurópskych štúdií; Magyar Nyelvtudományi Társaság.

BAUKO, JÁNOS [JÁN] 2012. A magyar és a szlovák (szláv) névtani terminológia összevetése [Comparing Hungarian and Slovakian (Slavic) Onomastic Terminology]. Névtani Értesitö 34: 157-166.

BAUKO, JÁNOS [JÁN] 2015a. Bevezetés a szocioonomasztikába [Introduction to Socio-onomastics]. Nitra: Univerzita Konštantína Filozofa v Nitre Fakulta stredoeurópskych štúdií.

BAUKO, JÁNOS [JÁN] 2015b. Magyar névkutatás a határokon túl [Hungarian Onomastics in Countries Neighbouring Hungary]. In: FARKAS, TAMÁs - SLíz, MARIANN eds., Magyar névkutatás a 21. század elején. Budapest: Magyar Nyelvtudományi Társaság; ELTE Magyar Nyelvtudományi és Finnugor Intézet. 63-89.

BAUKO, JÁN [JÁNOS] 2015c. Komparácia slovenských a mad’arských onomastických termínov. In: BALleKovÁ, KATARÍNA - KrÁliK, L'UBOR - MúCsKOvÁ, GABRIEla eds., Jazykovedné štúdie XXXII. Prirodzený vývin jazyka a jazykové kontakty. Bratislava: Veda. 254-262.

BENKÖ, LORÁND 1960. Megjegyzések terminus technikusokról [Notes on Terms]. Magyar Nyelv 56: $238-240$.

BEZLAJ, FRANCE et al. 1983. Osnoven sistem i terminologija na slovenskata onomastika. Osnovnaja sistema i terminologija slavjanskoj onomastiki. Grundsystem und Terminologie der slawischen Onomastik. Skopje: Makedonska akademija na naukite i umetnostite; Megunaroden komitet na slavistite; Komisija za slovenska onomastika. 
BÖLCSKEI, ANDREA 2010. A magyar településnevek korrelációs rendszerének alakulása a természetes névadás korszakában [The Correlational System of Hungarian Settlement Names in the Period of Non-official Place-naming Practices]. A Károli Gáspár Református Egyetem Magyar Nyelvtudományi Tanszékének Kiadványai 2. Budapest: Károli Gáspár Református Egyetem Magyar Nyelvtudományi Tanszéke.

BölCSKEI, ANDREA 2012. A helynév-standardizáció terminológiájáról [On the Terminology of Geographical Names Standardization]. Névtani Értesitö 34: 167-178.

BölCSKeI, ANDREa 2013a. Az „UNGEGN Glossary of Terms for the Standardization of Geographical Names" címü terminusjegyzék magyar változatának elkészítéséről [On Preparing the Hungarian Version of the UNGEGN Document Entitled "Glossary of Terms for the Standardization of Geographical Names"]. Névtani Értesitö 35: 11-21.

BÖLCSKEI, ANDREA 2013b. Challenges in updating the Hungarian terminology for geographical names standardization. Magyar Terminológia 6/2: 153-168. https://doi.org/10.1556/1206.2013.6.2.3

BölcskeI, ANDrea 2017. The Hungarian Versions of Two International Onomastic Terminological Glossaries. In: BölCSKeI, ANDREA - FARKAS, TAMÁs - Slíz, MARIANN eds., Magyar és nemzetközi névtani terminológia / Hungarian and International Onomastic Terminology. Uppsala; Budapest: International Council of Onomastic Sciences; Magyar Nyelvtudományi Társaság. 85-98. https://doi.org/10.26546/5061110.10

BöLCSKeI, ANDREA - FóRIS, ÁGOTA 2012. Névtan és terminológia 2: Névtan és egységesítés [Onomastics and Terminology 2: Onomastics and Standardization]. Névtani Értesitö 34: $125-126$.

Brendler, Andrea - Brendler, Silvio Hrsg. 2004. Namenarten und ihre Erforschung. Ein Lehrbuch für das Studium der Onomastik. Lehr- und Handbücher zur Onomastik 1. Hamburg: Baar-Verlag.

BuchKo, Dmytro Hryhorovych - TKachova, Natalia Vasylivna 2012. Slovnyk ukrains'koi onomastychnoi terminolohii. Kharkiv: Ranok. [= БУЧКО, ДМИТРО ГРИГОРОВИч - ТКАЧОВА, НАТАЛІЯ ВАСИЛІВНА 2012. Словник української ономастичної термінологї. Харків: Ранок.]

Dorion, Henri - Poirier, JeAn 1975. Lexique des termes utiles à l'étude des noms de lieux. Quebec: French and European Publications Inc.

FÁBIÁN, ZsUZSANNA 2001. Glossario dei termini piú importanti dell'Onomastica. In: FÁBIÁN, Zsuzsanna ed., Antologia di Onomastica Italiana. Budapest: Eötvös Loránd Tudományegyetem Bölcsészettudományi Kar Olasz Nyelv és Irodalom Tanszék. 291-299.

FARKAS, TAMÁS 2008. Szemlélet és terminológia a névkutatásban: a hivatalos magyar családnévváltoztatások kérdései [Approach and Terminology in Onomastic Research: The Questions of Official Family Name Changes in Hungary]. In: BöLCSKEI, ANDREA - N. CsÁsZI, ILDIKÓ eds., Név és valóság. A VI. Magyar Névtudományi Konferencia elöadásai. Balatonszárszó, 2007. június 22-24. A Károli Gáspár Református Egyetem Magyar Nyelvtudományi Tanszékének Kiadványai 1. Budapest: Károli Gáspár Református Egyetem Magyar Nyelvtudományi Tanszéke. 332-341.

FARKAS, TAMÁS 2011. Terminológiai munkálatok a névkutatás területén [Terminological Works in Onomastics]. Névtani Értesítö 33: 203-212.

FARKAS, TAMÁS 2012. Szempontok a magyar névtani terminológia megítéléséhez [On Some Characteristics and Problems of Hungarian Onomastic Terminology]. Névtani Értesitó 34: 139-148. 
FARKAS, TAMÁs 2013. Egy magyar névtani terminológiai szótár tervéröl [On a Plan of a Dictionary of Hungarian Onomastic Terms]. In: TóTH, SzERGEJ ed., Társadalmi változások - nyelvi változások. Alkalmazott nyelvészeti kutatások a Kárpát-medencében. A XXII. MANYE Kongresszus elöadásai. Szeged, 2012. április 12-14. A MANYE Kongresszusok Előadásai 9. Budapest; Szeged: MANYE; Szegedi Egyetemi Kiadó Juhász Gyula Felsőoktatási Kiadó. 442-445.

FARKAS, TAMÁS 2014a. Dimenzionális szemlélet a névkutatásban. Általános kérdések és a családnévkutatás példája [The Dimensional Approach in Onomastics. General Questions and the Example of Family Name Research]. Névtani Értesitö 36: 9-22.

FARKAS, TAMÁS 2014b. Onomastic Terminology in Hungarian - Situation, Problems and Needs. In: Tort i Donada, JoAn - Montagut i Montagut, Montserrat eds., Els noms en la vida quotidiana. Actes del XXIV Congrés Internacional d'ICOS sobre Ciències Onomàstiques. I Names in daily life. Proceedings of the XXIV ICOS International Congress of Onomastic Sciences. Biblioteca Tècnica De Política Lingüística 11. Barcelona: Generalitat de Catalunya. 14-20. http://www.gencat.cat/llengua/BTPL/ICOS2011/003.pdf \& https://doi.org/10.2436/15.8040.01.3

FARKAS, TAMÁS 2015a. A nemzetközi névkutatás és magyar kapcsolatai [International Onomastics and Its Hungarian Relations]. In: FARKAS, TAMÁs - SLÍz, MARIANN eds., Magyar névkutatás a 21. század elején. Budapest: Magyar Nyelvtudományi Társaság; ELTE Magyar Nyelvtudományi és Finnugor Intézet. 23-47.

FARKAS, TAMÁS 2015b. A magyar családnevek változástipológiájáról [The Typology of Changes in the History of Hungarian Family Names]. Magyar Nyelv 111: 395-408. https://doi.org/10.18349/ MagyarNyelv.2015.4.395

FARKAS, TAMÁS 2016. The Typology of Changes in the History of Hungarian Surnames. In: Hough, CAROlE - IzDEBSKa, Daria eds., 'Names and Their Environment'. Proceedings of the 25th International Congress of Onomastic Sciences, Glasgow, 15-19 August 2014. 3. Anthroponomastics. Glasgow: University of Glasgow. 55-64. http://www.icos2014.com/wp-content/ uploads/icos2014_v3_55.pdf

FeHÉRTÓi, KATALIN 1966. A német névtudomány két újdonsága [Two Novelties in German Onomastics]. Magyar Nyelv 62: 245-247.

FÖLDI, ERVIN 1979. Elöterjesztés a tenger alatti domborzati nevekröl [Report on Names for Seabed Relief Features]. A Földrajzinév-Bizottság 32. ülésének jegyzőkönyve. Manuscript. Budapest.

FöLDI, ERVIN 1992. ENSZ földrajzinév-egységesítési szakkifejezések szótára [UN Technical Terminology Employed in the Standardization of Geographical Names]. Névtani Értesitö 14: 127-138.

Galkowski, Artur 2010. Problemi di terminologia onomastica. Contributi per un dibattito. Rivista Italiana di Onomastica 16: 604-624.

GALKOWSKI, ARTUR 2012. Aktualizowana lista podstawowych haset terminologii onomastycznej w języku polskim. http://onomastyka.uni.lodz.pl/strona-glowna/terminologia-polska

GYŐRFFY, ERZSEBET 2007. A svéd névtudományról és helynévkutatásról [Onomastics and Place Name Studies in Sweden]. Névtani Értesitö 29: 247-257.

GYÖRFFY, ERZSÉBET 2012. A hivatalos név terminus [The Term Official Name]. Magyar Nyelvjárások 50: 27-35.

HAJdú, MinÁly 1974a. Vitainditó a névtudomány müszavairól [Introduction to a Debate on Onomastic Terms]. Bokor Levelek 12. Manuscript. Budapest.

HAJDÚ, MiHÁLY 1974b. Elöterjesztés a magyar névtudomány müszavainak egységesitéséröl [A Proposal on the Standardization of Hungarian Onomastic Terms]. Manuscript. Budapest.

HAJDÚ, MiHÁLy 1979. A magyar névtudomány müszavai [Terms in Hungarian Onomastics]. Névtani Értesitő 2: 18-28. 
HAJDÚ, MihÁly 1981. J. Soltész Katalin, A tulajdonnév funkciója és jelentése [Katalin J. Soltész: The Function and Meaning of Proper Names. (Review)]. Magyar Nyelv 77: 109-113.

HaJdÚ, MiHÁly 2002. Tulajdonnév és dialektológia [Proper Names and Dialectology]. In: SzABÓ, GÉZA - Molnár, Zoltán - GutTMann, MikLós eds., IV. Dialektológiai Szimpozion. Szombathely, 2001. augusztus 23-25. A Berzsenyi Dániel Tanárképző Főiskola Magyar Nyelvészeti Tanszékének Kiadványai 5. Szombathely: Berzsenyi Dániel Főiskola Magyar Nyelvészeti Tanszéke. 104-119.

Hajdú, MinÁly 2003. Általános és magyar névtan. Személynevek [General and Hungarian Onomastics. Personal Names]. Budapest: Osiris Kiadó.

HAJDÚ, MiHÁly 2006. Álnév - fedőnév - jelige - internetnév [Pseudonym - Code Name - Code Word - Internet Name]. In: Mártonfi, AtTILA - PAPP, KornÉlia - Slíz, MARIANN eds., 101 irás Pusztai Ferenc tiszteletére. Budapest: Argumentum. 257-266.

HAJDÚ, MiHÁly 2009. A névváltozások és névváltoztatások rendszere [The System of Changes of Personal Names]. In: FARKAS, TAMÁs - KozMA, IsTVÁn eds., A családnév-változtatások történetei időben, térben, társadalomban. Budapest: Gondolat Kiadó; Magyar Nyelvtudományi Társaság. 29-40.

Hajdú, Minály 2010. Közös tervek Mezö Andrással [Common Plans with András Mező]. In: P. LAKATOS, IlONA - SeBeStYÉN, Zsolt eds., Emlékkönyv Mezö András tiszteletére. Nyíregyháza: Bessenyei Könyvkiadó. 23-28.

HAJDÚ, MiHÁLy 2011. Farkas Tamás, Családnév-változtatás Magyarországon [Tamás Farkas: Family Name Changes in Hungary. (Review)]. Magyar Nyelv 107: 345-347.

HÁRI, GYUla 2010. Épületnév, építménynév, létesítménynév [Names for Houses, Buildings and Establishments]. Névtani Értesitö 32: 99-116.

HARVALÍK, MiLAN 2005. Towards a new millennium - towards a common onomastic terminology? In: Brylla, Eva - WahlBerg, Mats eds., Proceedings of the 21st International Congress of Onomastic Sciences. Uppsala 19-24 August 2002. Uppsala: Språk- och folkminnesinstitutet. 1: $160-171$

HARVALÍK, MiLAN 2007. K voprosu o sovremennoj onomastičeskoj terminologii. Voprosi onomastiki 2/4: 5-13. [= ГАРВАЛИК, МилАН 2007. К вопросу о современной ономастической терминологии. Вопросы ономастики 2/4: 5-13.]

Harvalík, Milan 2014. Towards a common onomastic terminology? The next step. In: TORT I Donada, JoAn - Montagut i Montagut, Montserrat eds., Els noms en la vida quotidiana. Actes del XXIV Congrés Internacional d'ICOS sobre Ciències Onomàstiques. / Names in daily life. Proceedings of the XXIV ICOS International Congress of Onomastic Sciences. Biblioteca Tècnica De Política Lingüística 11. Barcelona: Generalitat de Catalunya. 21-25. http://www.gencat.cat/llengua/BTPL/ICOS2011/004.pdf \& https://doi.org/10.2436/15.8040.01.4

HaRVALíK, Milan - CAFFARELli, ENZo 2007. Onomastic terminology: an international survey / Terminologia onomastica: un'inchiesta internazionale. Rivista Italiana di Onomastica 13: 181-220.

HENNO, KAIRIT - PÄLl, PEETER 2003. Onomastika termineid. http://www.eki.ee/nimeselts/nimeterm.htm Hoffmann, István 1993. Helynevek nyelvi elemzése [Linguistic Analysis of Place Names]. A Debreceni Kossuth Lajos Tudományegyetem Magyar Nyelvtudományi Intézetének Kiadványai 61. Debrecen: Debreceni Kossuth Lajos Tudományegyetem Magyar Nyelvtudományi Intézete.

HofFMANN, IsTVÁN 1999. A helynevek rendszerének nyelvi leírásához [On the Linguistic Description of Place Name Systems]. Magyar Nyelvjárások 37: 207-216. 
HoffmanN, István 2002. Magyar névkutatás az ezredfordulón [Hungarian Onomastics at the Turn of the Millennium]. In: Hoffmann, István - JuHÁsz, Dezsö - PÉntek, JÁnos eds., Hungarológiai és dimenzionális nyelvszemlélet. Elöadások az V. Nemzetközi Hungarológiai Kongresszuson. Debrecen; Jyväskylä: n.p. 9-22.

HofFMANN, IstVÁN 2003. Magyar helynévkutatás 1958-2002 [Hungarian Place Name Research 1958-2002]. A Magyar Névarchívum Kiadványai 7. Debrecen: Debreceni Egyetem Magyar Nyelvtudományi Tanszék.

Hoffmann, István 2007. Helynevek nyelvi elemzése [Linguistic Analysis of Place Names]. 2nd edition. Segédkönyvek a nyelvészet tanulmányozásához 67. Budapest: Tinta Könyvkiadó.

Hoffmann, István 2008. A személynévrendszerek leírásához [On the Description of Personal Name Systems]. Magyar Nyelvjárások 46: 5-20.

HofFMANN, ISTVÁN 2012. Elmélet és terminológia a magyar helynévkutatásban [Theory and Terminology in Hungarian Toponomastics]. Névtani Értesitö 34: 127-137.

HOFFMANN, ISTVÁN - TÓTH, VALÉRIA 2015. Viewpoints on the cognitive-pragmatic description of personal names. Word: Journal of the International Linguistic Association 61: 141-164. https://doi.org/10.1080/00437956.2015.1033832

J. SoltÉsz, KATAlin 1979. A tulajdonnév funkciója és jelentése [The Function and Meaning of Proper Names]. Budapest: Akadémiai Kiadó.

JuHÁsz, DEzső 2004. A névtan néhány terminológiai és tudományrendszertani kérdéséröl [On Some Terminological and Taxonomic Questions of Onomastics]. In: FARKAS, FerENC ed., Magyar névtani kutatások itthon és határainkon túl. Névtani tanácskozás Jászberényben. 2003. október 17-18. Budapest: Magyar Nyelvtudományi Társaság; Szent István Egyetem Jászberényi Főiskolai Kar; TIT Jászsági Szervezete; Jászok Egyesülete. 165-169.

JuHÁsz, Dezsö 2010. A személynevek mint a nyelvföldrajz tárgyai [Personal Names as Subjects of Linguistic Geography]. In: Vörös, FERENC ed., A nyelvföldrajztól a névföldrajzig. A 2010. június 8-i szombathelyi tanácskozás elöadásai. A Magyar Nyelvtudományi Társaság Kiadványai 234. Budapest; Szombathely: Magyar Nyelvtudományi Társaság; NyME Savaria Egyetemi Központ. 31-39.

Kaleta, Zofia 1998. Kierunki i metodologia badań. Terminologia. In: Rzetelska-Feleszko, EwA ed., Polskie nazwy wlasne. Encyklopedia. Warszawa; Kraków: Wydawnictwo Instytutu Języka Polskiego PAN. 45-81.

KÁlmÁN, BÉla 1982. Névtani Értesítő. Szerk. Hajdú Mihály és Mező András. 2-5. szám [Mihály Hajdú and András Mező eds.: Névtani Értesítő No. 2-5. (Review)]. Magyar Nyelv 78: 502-505.

Kiviniemi, EERO - PitKÄNEN, Ritva-LiISA - Zilliacus, KuRT eds. 1974. Nimistöntutkimuksen terminologia. Terminologin inom namnforskningen. Castrenianumin toimitteita 8. Helsinki: Castrenianum.

KOROMPAY, KLÁRA 2011. Az irodalmi névadás fogalmáról [On the Concept of Name Giving in Literature]. Létünk 41/3: 86-93.

Kovalovszky, Miklós 1934. Az irodalmi névadás [Name Giving in Literature]. A Magyar Nyelvtudományi Társaság Kiadványai 34. Budapest: Magyar Nyelvtudományi Társaság.

MARCATO, CARLa 2009. Nomi di persona, nomi di luogo. Introduzione all'onomastica italiana. Bologna: Il Mulino.

MÁRTON, MÁTyÁs 1992. A magyar tengerfenék-domborzati nevek megalkotásáról [Creating the Undersea Feature Names in the Hungarian Language]. Névtani Értesitö 14: 84-116. 
MÁRTON, MÁTYÁs 2012. A világtenger kartográfus szemmel [World Oceans with a Cartographer's Eyes]. Budapest: Eötvös Loránd Tudományegyetem Informatikai Kar Térképtudományi és Geoinformatikai Tanszék.

MÁRTON, MÁTYÁs - DutKó, ANDRÁs ÁKos eds. 2003. Standardization of Undersea Feature Names / Tengerfenék-domborzati képzödmények neveinek egységesitése. 2. angol-magyar változat. 2nd English-Hungarian Version. Manuscript. Budapest.

MiKeSY, SÁNDOR 1959. Írói névadás - irodalmi névadás [Names in Literature - Literary Onomastics]. Magyar Nyelv 55: 110-112.

MiKeSY, SÁNDOR 1960. Mi legyen az onomasztika magyar neve [What Should be the Hungarian Term for Onomastics]? Magyar Nyelv 56: 236-238.

MizSER, LAJOS 1979. Három finn névtudományi munka [Three Works on Finnish Onomastics]. Magyar Nyelv 75: 246-250.

N. FODOR, JÁNOS 2010. Személynevek rendszere a kései ómagyar korban. A Felsö-Tisza-vidék személyneveinek nyelvi elemzése (1401-1526) [The System of Personal Names in the Late Old Hungarian Language. Linguistic Analysis of Personal Names of Northeast Hungary (1401-1526)]. Magyar Névtani Értekezések 2. Budapest: ELTE BTK Magyar Nyelvtörténeti, Szociolingvisztikai, Dialektológiai Tanszéke.

N. FODOR, JÁNOS 2014. A történeti személynévföldrajz mint a nyelvföldrajz egyik kutatási területe I. A nyelvföldrajzi módszer a névtani kutatásokban [The Geography of Historical Personal Names as a Research Area of Geolinguistics. Part I. Name Geographic Methods in Name Studies]. Névtani Értesítö 36: 23-41.

NimCHUK, VASYL' VASYL'OVYCH 1966. Ukrains'ka onomastychna terminolohia. Povidomlennia Ukrains'koi onomastychnoi komisii 1: 24-43. [= НІмчук, ВАСиль ВАСильОВич 1966. Українська ономастична термінологія. Повідомлення Украӥнської ономастичної комісії 1: 24-43.]

NySTRÖM, STAFFAN 2014. The terminological work of UNGEGN and ICOS - a presentation and a comparison. In: TORT i DONADA, JOAN - Montagut i MOnTAgut, MONTSERrat eds., Els noms en la vida quotidiana. Actes del XXIV Congrés Internacional d'ICOS sobre Ciències Onomàstiques. / Names in daily life. Proceedings of the XXIV ICOS International Congress of Onomastic Sciences. Biblioteca Tècnica De Política Lingüística 11. Barcelona: Generalitat de Catalunya. 52-57. http://www.gencat.cat/llengua/BTPL/ICOS2011/008.pdf \& https://doi.org/10.2436/15. $\underline{8040.01 .8}$

ÖRDÖG, FERENC 1989. Helynévgyüjteményeink mint az onomatodialektológia forrásai [Hungarian Place Name Repertories as Sources of Onomato-dialectology]. Baranyai Müvelödés 1989/3: $27-33$.

ÖRDÖG, FERENC 1991. Személyneveink onomato-dialektológiai vizsgálatáról [On the Onomatodialectal Analysis of the Hungarian Personal Names]. In: HAJdú, MiHÁLy ed., Emlékkönyv Benkö Loránd hetvenedik születésnapjára. Budapest: ELTE. 488-496.

ÖRDÖG, FERENC 2010. Névföldrajz, onomatodialektológia, névdialektológia [Name Geography, Onomato-dialectology, Name Dialectology]. In: VÖRÖS, FERENC ed., A nyelvföldrajztól a névföldrajzig. A 2010. június 8-i szombathelyi tanácskozás elöadásai. A Magyar Nyelvtudományi Társaság Kiadványai 234. Budapest; Szombathely: Magyar Nyelvtudományi Társaság. 127-133.

PAPP, LÁSZLÓ 1955. Szabó István: Bács, Bodrog és Csongrád megye dézsmalajstromai 1522-böl [István Szabó: 1522 talliage lists of Bács, Bodrog and Csongrád counties (Review)]. Magyar Nyelv 51: 258-263.

PETR, JAN 1969. Lužickosrbská onomastická terminologie. Zpravodaj Mistopisné komise ČSAV 10: $538-552$. 
PODOL'SKAJA, NATAL'JA VladimirovNA 1978. Slovar' russkoj onomastičeskoj terminologii. Moskva: Nauka. [= ПОДОЛЬСКАЯ, НАТАЛЬЯ ВЛАДИМИРОВНА 1978. Словарь русской ономастической терминологии. Москва: Наука.]

PodOL'SKAJA, NATAL'JA VladimiRovna 1988. Slovar' russkoj onomastičeskoj terminologii. Moskva: Nauka. 2nd edition. [= ПодОЛьСКАЯ, НАТАЛЬя ВЛАДИМИРОВНА 1988. Словарь русской ономастической терминологии. Москва: Наука.]

POKOLY, BÉla 2013. Az exonima kifejezés értelmezésének változása a földrajzinév-egységesítés nemzetközi gyakorlatában [Changing Definitions of the Term Exonym in the International Practice of Geographical Names Standardization]. Névtani Értesitó 35: 71-75.

PoKOly, BÉlA - BÖlCSKEI, ANDREA - MiKESY, GÁBOR 2015. The exonym/endonym divide: Examples highlighting different aspects for defining the terms. In: JoRdan, PETER - WoOdMan, PAul eds., Confirmation of the Definitions. Proceedings of the 16th UNGEGN Working Group on Exonyms Meeting, Hermagor, 5-7 June 2014. Hamburg: Verlag Dr. Kovac. 155-168.

RAÁTZ, JudiT 1999. Intern Otto, Angicica, Lütyö és a többiek, azaz névválasztás a számítógépes csevegöcsatornán [Intern Otto, Angicica, Lütyö and Others, i.e. Name Choice in Internet Chat Forums]. Névtani Értesítö 21: 262-266.

RAÁtZ, Judit 2008. Névadás az interneten [Naming Practices on the Internet]. In: BölcskeI, ANDREA - N. Császi, ILDikó eds., Név és valóság. A VI. Magyar Névtudományi Konferencia elöadásai. Balatonszárszó, 2007. június 22-24. A Károli Gáspár Református Egyetem Magyar Nyelvtudományi Tanszékének Kiadványai 1. Budapest: Károli Gáspár Református Egyetem Magyar Nyelvtudományi Tanszéke. 443-450.

RAÁTZ, JUDIT 2011. Nick as self-attributed name. Nouvelle Revue d'Onomastique 53: 183-209.

ROOM, AdRIAn 1996. An Alphabetical Guide to the Language of Name Studies. Lanham (MD); London: The Scarecrow Press.

Rzetelska-Feleszko, Ewa - Cieślikowa, Aleksandra - Duma, Jerzy eds. 2002-2003. Słowiańska onomastyka. Encyklopedia 1-2. Warszawa; Kraków: Towarzystwo Naukowe Warszawskie.

SCHMIDT, Tом 1981. Fagordliste for norsk namnegransking. Oslo: Institutt for namnegransking Universitetet i Oslo.

SLíz, MARIANN 2010. A történeti személynévkutatás terminológiájához [On Terminology of Historical Personal Name Research]. Névtani Értesitö 32: 157-172.

SLíz, MaRianN 2012. Terminusok keletkezése és változása [Appearance and Change of Terms]. Névtani Értesitö 34: 149-156.

SLíz, MARIANN 2014. A terminológiai egységesülés hiányának következményei a névtudományban [The Consequences of the Lack of Unified Terminology in Onomastics]. In: LENGYEL, KLÁRA - VesZELsZKi, ÁGNES eds., Tudomány, technolektus, terminológia. A tudományok, szakmák nyelve. Budapest: Éghajlat Könyvkiadó. 249-258.

SLíz, Mariann 2015. Általános névtani kérdések [General Onomastics]. In: FARKAS, TAMÁs SLíz, MarianN eds., Magyar névkutatás a 21. század elején. Budapest: Magyar Nyelvtudományi Társaság; ELTE Magyar Nyelvtudományi és Finnugor Intézet. 93-114.

SLíz, MARIANN in press. A személynevekkel kapcsolatos névtani és jogi terminológia [Onomastic and Legal Terminology Connected to Personal Names]. In press.

SMith, ElSDON COLES 1967. Treasury of Name Lore. Sketches and Observations on the Names We Bear. New York; Evanston; London: Harper \& Row. 
SVOBOda, JAN - ŠMilauer, Vladimír - OlivovÁ-NezBEdovÁ, LibuŠE - Oliva, KAREL - WitKowSKI, THEODOLIUS 1973. Základní soustava a terminologie slovanské onomastiky. Grundsystem und Terminologie der slawischen Onomastik. Zpravodaj Mistopisné komise ČSAV 14: 1-280.

SzENTGYÖRGYI, RUdOLF 2016. A Tihanyi alapítólevél személynevei III. Személynevek és helynevek kapcsolata [Personal Names in the Foundation Deed of Tihany Abbey. Part III. Relations between Personal Names and Place Names]. Névtani Értesitö 38: 9-18.

T. SOMOGYI, Magda 2015. Az írói névadás vizsgálata [Literary Onomastics]. In: FARKAS, TAMÁs - Slíz, MarianN eds., Magyar névkutatás a 21. század elején. Budapest: Magyar Nyelvtudományi Társaság; ELTE Magyar Nyelvtudományi és Finnugor Intézet. 207-226.

TAKÁCS, JUDIT in press. Finn-magyar kontrasztív névtani (terminológiai) vizsgálatok a személynévtípusok megnevezésének köréből [Finnish-Hungarian Contrastive Onomastic (Terminological) Analyses Concerning Terms for Types of Personal Names]. In press.

TóTH, LÁszló 2015. Alapfogalmak az irodalmi onomasztikában [Basic Concepts in Literary Onomastics]. Acta Academiae Agriensis Sectio Linguistica Hungarica 42: 203-215.

Tóth, VALÉRIA 2005. The Changes of the Hungarian Settlement Names. In: MATICSÁK, SÁNDOR ed., Settlement Names in the Uralian Languages. Onomastica Uralica 3. Debrecen; Helsinki: n.p. 135-153.

TÓTH, VALÉRIA 2008. Településnevek változástipológiája [Typology of Settlement Name Changes]. A Magyar Névarchívum Kiadványai 14. Debrecen: Debreceni Egyetem Magyar Nyelvtudományi Tanszéke.

UdVARI, ISTVÁN 1981. Н. В. Подольская: Словарь русской ономастической терминологии. [(Review.)] Névtani Értesítö 6: 71-3.

VÁCZINÉ TAKÁCs, EdIT 2016. Az írói névadás sajátosságai Karinthy Frigyes müvei alapján bemutatva [Specificities of Writers' Name Giving as Reflected in the Works of Frigyes Karinthy]. $\mathrm{PhD}$ thesis defended at Eötvös Loránd University, Budapest. Manuscript. https://doi.org/10.15476/ ELTE.2016.147

VÁRNAI, JUDIT SZILVIA 2005. Bárhogy nevezzük... A tulajdonnév a nyelvben és a nyelvészetben [Whatever the Name is ... Proper Names in the Language and in Linguistics]. Segédkönyvek a nyelvészet tanulmányozásához 42. Budapest: Tinta Könyvkiadó.

VÁRNAI, JUDIT SZILVIA ed. n.d. Angol-magyar nyelvészeti glosszárium / English-Hungarian glossary of linguistical terms. http://mnytud.arts.klte.hu/glosseng.htm \& http://mnytud.arts.klte.hu/ glossary.htm

Vasileva, Natalia 2014. Koordinierung der onomastischen Terminologie: die Suche nach der lexikographischen Lösung. In: TorT I DonadA, JoAN - MonTAgut I MontAgut, MonTSERRAT eds., Els noms en la vida quotidiana. Actes del XXIV Congrés Internacional d'ICOS sobre Ciències Onomàstiques. / Names in daily life. Proceedings of the XXIV ICOS International Congress of Onomastic Sciences. Biblioteca Tècnica De Política Lingüística 11. Barcelona: Generalitat de Catalunya. 99-106. http://www.gencat.cat/llengua/BTPL/ICOS2011/013.pdf \& https://doi.org/10.2436/15.8040.01.13

VINCZE, LÁSZLÓ 2004. A magyar belterületi helynevek kutatásában elért eddigi eredmények és további feladatok (A hazai és külföldi teljesítmények összevetése) [Achievements and Further Tasks in the Research of Hungarian Names for Inhabited Places. (A Comparison of the Hungarian and Foreign Achievements)]. In: FARKAS, FERENC ed., Magyar névtani kutatások itthon és határainkon túl. Névtani tanácskozás Jászberényben. 2003. október 17-18. Budapest: Magyar Nyelvtudományi Társaság; Szent István Egyetem Jászberényi Főiskolai Kar; TIT Jászsági Szervezete; Jászok Egyesülete. 187-191. 
VÖRÖS, FERENC 2009. Névváltoztatás és névhelyreállítás a kisebbségi magyar névhasználat tükrében: terminológiai javaslat egy névtani jelenség megnevezésére [Name Change and Name Reconstruction in the Name Use of Hungarian Minorities: Terminological Proposal for Identifying an Onomastic Phenomenon]. In: FARKAS, TAMÁs - KozMA, IsTVÁN eds., A családnév-változtatások történetei időben, térben, társadalomban. Budapest: Gondolat Kiadó; Magyar Nyelvtudományi Társaság. 57-74.

WALTHER, HANS 1998. Namenkunde und geschichtliche Landeskunde 2. Erläuterung namenkundlicher Fachbegriffe. Leipzig: Institut für Slavistik, Universität Leipzig.

WitKowski, TeOdolius 1964. Grundbegriffe der Namenkunde. Berlin: Akademie Verlag.

Witkowski, TeOdolius 1995. Probleme der Terminologie. In: Eichler, ERnst et al. eds., Namenforschung / Name Studies / Les noms propres. Ein internationales Handbuch zur Onomastik / An International Handbook of Onomastics / Manuel international d'onomastique. Handbücher zur Sprach- und Kommunikationswissenschaft 11. Berlin; New York: Walter de Gruyter. 1: 288-294.

TAMÁS FARKAS

ORCID: 0000-0002-7732-2302

ELTE Eötvös Loránd University Institute of Hungarian Linguistics and Finno-Ugric Studies Budapest, Hungary 
BÖLCSKEI-FARKAS-SLÍz eds., Magyar és nemzetközi névtani terminológia. Hungarian and International Onomastic Terminology. Uppsala-Budapest: International Council of Onomastic Sciences - Magyar Nyelvtudományi Társaság, 2017. 85-97. DOI: $10.26546 / 5061110.10$

\section{The Hungarian Versions of Two International Onomastic Terminological Glossaries}

1. Two international onomastic terminological glossaries. The two international glossaries of onomastic terminology published in the present volume were compiled by the Working Groups on Terminology of two international scientific committees of onomastics, aimed for different purposes. Experts at the International Council of Onomastic Sciences (ICOS) have collected the key terms of the discipline of onomastics, used primarily in professional communication, provided their definitions, together with general notes on onomastic terminology, and references from the specialised literature. Consultants at the United Nations Group of Experts on Geographical Names (UNGEGN) have prepared the list of linguistic, geographical, cartographical, documentary and information technological terms adopted in the standardization of geographical names, for specialists taking part in the practice of geographical names standardization. A brief description of the two international onomastic terminological glossaries, concerning the circumstances of their creation, their distinct aims and purposes, as well as their unique features as term lists is given below. A short introduction regarding the principles and methods of compilation characteristic of the Hungarian versions is also provided.

2. Main ambitions at ICOS. The International Council of Onomastic Sciences ${ }^{1}$ was founded in 1949, its current Statutes adopted in 2002 defines its aims as follows: "the advancement, representation, and co-ordination of onomastic sciences on an international level and in an interdisciplinary context, and the promotion of World Congresses at reasonable intervals" (ICOS Statutes Article 3). The successful operation of the Council has continuously been facilitated by the activities of its two standing working groups, the ICOS Bibliography Group and the ICOS Terminology Group (Icosweb, FARKAS 2015: 23$24,26-27,28,31)$.

The establishment of the Terminology Group was proposed by Milan Harvalík (Czech Republic), the current president of ICOS at the 2002 ICOS Congress in Uppsala, Sweden. The working group began work in 2004, and published two smaller glossaries of terms in 2011 on the Terminology subpage of Icosweb (cf. HARVALÍK 2005, 2014). One of the glossaries lists and defines a few onomastic terms mostly used by the professional community in English; furthermore, it provides general comments on the linguistic features of onomastic terms (Icosweb Terminology). The other glossary presents and

\footnotetext{
${ }^{1}$ Beforehand: International Committee of Onomastic Sciences (1949-1993).
} 
explains 70 basic onomastic terms in English, French and German (List of Key Onomastic Terms, see Icosweb Terminology). ${ }^{2}$

2.1. The List of Key Onomastic Terms. The glossary containing 70 basic onomastic terms was first compiled by the members of the ICOS Terminology Group in English. The glossary gives illustrative examples for most terms, as well as term forms, and definitions. Notes and suggestions on meaning (e.g. anthroponymy, hagionym, oronym), forms (e.g. metronym), and use (e.g. first name, odonym) are also connected to certain terms; in some cases the term's status as a proper name (e.g. ethnonym, inhabitant name) is also indicated. In other cases, the editors inform readers about the sub-, super- or coordination of terms (hyponyms, hyperonyms, co-hyponyms; consider, for instance, the relations between a nickname and a by-name, a street name and a hodonym, a choronym and a macrotoponym); while cross-references help identify synonymous terms and term variations (see, for example, the headwords animal name and zoonym, minor name and microtoponym, name bearer and denominatum).

The French and German variations of the glossary were prepared based on the English term list, each adopting slightly different approaches. The French glossary, promoting terms in the national language, is a proper translation of the English term list; the German version, however, first provides the term in the national language, then its English equivalent, followed by the definition and, if applicable, a remark on term use and relations in German. The German version includes several additional language specific notes in comparison to the original English text (see, for instance, the notes on $\mathrm{An}$ throponym, Appellativierung, Beiname, Mikrotoponym). The German version also contains a few cross-references, involving mostly terms of German origin as headwords, next to which English equivalents can not be found, because these latter terms are included in the main entries of the referenced, synonymous terms, together with the target definitions (see, for example, the German terms Deckname, Gewässername, Kosename, Riedname).

The editors of both the French and the German versions faced many difficulties characteristic of interlingual terminological work: from time to time choices had to be made regarding whether a term of an international background or a term of national language origin should be used as a headword of the main entry; occasionally, the lack of terms as well as the existence of surplus terms caused problems. In the German version the above mentioned cross-reference terms of German origin are explained in main entries introduced by synonymous international terms as headwords (Kryptonym, Hydronym, Hypokoristikon, Mikrotoponym, respectively), thus terms of an international background are preferred over those originating from the national language. A similar approach (i.e. the use of main entries and cross-references) was adopted in the German glossary when multiple terms of German origin or of an international background could be identified as equivalents of a single English term in the German language (e.g. nickname = Neckname in the cross-reference and Spitzname in the main entry; deonym = Epotoponym in the cross-reference and Deonym in the main entry).

\footnotetext{
${ }^{2}$ English, French and German are the official languages of ICOS. In the English and German glossaries, one can also find the selected international bibliography of onomastic terminology, comprising relevant works published between 1961 and 2002.
} 
The languages also differ in the number of traditionally established synonymous terms for a concept. Whenever there are fewer synonymous terms in German than in English, the German glossary lists the German terms accompanied by more than one English equivalent (e.g. Familienname = family name, surname, last name in entries and Zuname in the cross-reference; Vorname = first name, given name in the main entries and Taufname $=$ Christian name in the cross-reference). As the French glossary does not contain English equivalents, the lack of the synonymous terms for a concept can only be unfolded indirectly (e.g. no cross-reference is given to nom de famille, or to prénom). Both the French and German versions of the glossary contain a term missing from the English version (cf. the entry onymisch in the German, and the entry toponymiste in the French list).

The List of Key Onomastic Terms successfully describes the peculiarities of the actual use of the terms under discussion, which is manifested in the acceptance of the glossary by field experts. The use of onomastic terms as defined in the glossary in ICOS publications, at ICOS congresses, in conference papers as well as other pieces of writing on onomastics has more and more become an expectation.

2.2. The Hungarian version of the ICOS glossary. The necessity of compiling multiple national language versions of the glossary was publicly declared at the ICOS Terminology Group meeting extended with experts interested in the topic in Barcelona, on 6th September 2011. This goal was re-expressed at the next group meeting organised in a similar way in Glasgow, on 26th August 2014. Participants here agreed to provide and publish the glossary in their respective mother tongues. Andrea Bölcskei, Tamás Farkas and Mariann Slíz represented Hungary at the Glasgow meeting. The Hungarian version of the List of Key Onomastic Terms - along with a supplementary HungarianEnglish term index and a quadrilingual list presenting English-Hungarian-GermanFrench term equivalents - was prepared by Bence Attila Oláh, university student (Károli Gáspár University, Faculty of Humanities, English Studies BA, Specialisation in Translation and Special Languages, then Terminology MA), under the supervision of Andrea Bölcskei, in 2015.

Several difficulties concerning terminological harmonization between languages, drafting definitions, choosing appropriate illustrative examples, elaborating the structure of the glossary had to be solved in preparation of the Hungarian version of the term list. The main principles of the work, illustrated with examples if necessary, are presented below.

Similarly to the German and the French versions, the Hungarian term list is based on the original, English glossary. The structure of the Hungarian glossary aims to indicate English-Hungarian term equivalents; to maintain the system of main entries and crossreferences used in the original glossary; and to adjust the contents and the form of the list to that of the UNGEGN Glossary, which lists terms for the standardization of geographical names (see below), also published in the present volume. Entries have thus been built up as follows: the serial number of the entry is followed by the English term as a headword, then the Hungarian equivalent(s) has (have) been provided, and finally the definition (in the case of main entries), or the reference (in the case of cross-references) has been listed. As a result, entries in the Hungarian term list - contrary to the German and French versions of the ICOS list, but in accordance with the UNGEGN Glossary - 
follow the alphabetical order of the English terms, i.e. the sequence of the entries in the original English ICOS term list.

In identifying Hungarian equivalent(s) of English terms, traditionally established expressions, mostly of national language origin have been given preference; recently adopted, less frequent terms of an international background have been listed after the relevant terms of Hungarian origin in parentheses, e.g. 01 névváltozat (= allonima); ${ }^{3} 19$ népnév (= etnonima); 27 szentnév (= hagionima); 29 víznév (= hidronima); 68 helynév (= toponima). Naturally, if only a term of an international background is available in Hungarian, this equivalent has been given (e.g. 16 endonima, 20 exonima, 33 makrotoponima, 35 mikrotopomina). Hungarian terms of an international background, regardless of the morphology of their English equivalents, have been presented in the form in which they appear in Hungarian specialized communication, e.g. 13 denominatum (English) = megnevezett (= denotátum) (Hungarian). If an English term does not have a proper Hungarian equivalent, the Hungarian version of the term of an international background has been adopted (e.g. 10 koronima, 18 ergonima), or, alternatively, a term of Hungarian origin has been elaborated (e.g. 09 informális név, 42 szigetnév). In certain cases these methods have been combined, e.g. 34 anyanévi eredetü név (= matronimikum, metronimikon); 53 apanévi eredetü név (= patronimikum, patronimikon). The glossary also indicates if the Hungarian equivalent of an independent English term of an international background can only be identified as a component of Hungarian terms (e.g. 49 -onima as second constituent).

In approving English-Hungarian term equivalencies, attention has been given to the (attitudinal) equality of the concepts indicated by the terms concerned, e.g. 22 first name and 24 forename = utónév (sequence of name components); 21 family name = családnév (function); 32 last name and 64 surname = vezetéknév (sequence of name components). If possible, English terms related through identical term components have been rendered with the help of Hungarian terms with similar structural features, e.g. 67 toponomastics = helynévkutatás, helynévtan (= toponomasztika), 68 toponym = helynév (= toponima) and 69 toponymy = helynévállomány. The traditionally established sub-, super- and coordination of Hungarian terms has been maintained and indicated in the Hungarian version of the term list (e.g. 68 helynév [= toponima] in certain cases a synonym of 25 földrajzi név, 43 ragadványnév a subcategory of 09 informális név in Hungarian). (On a number of theoretical questions of Hungarian onomastic terms of national language origin and of an international background, cf. Farkas 2012, 2014; on certain factors influencing the appearance and changes of Hungarian onomastic terms, cf. Slíz 2012.)

Definitions in the main entries are based on the form and contents of those found in the original English term list. As a result, paraphrases of term meanings in the Hungarian version are regularly followed by illustrative place-name examples, and, if necessary, notes on term use have also been provided. A cross-reference consists of the English and Hungarian headwords of the main entry defining the term, and the number of the relevant main entry in parentheses. Illustrative place-name examples have mostly been taken from the original English text (see the examples for 09 informális név, 31 lakossági név, 43 ragadványnév), in certain cases supplemented by Hungarian examples (see the examples

\footnotetext{
${ }^{3}$ The Hungarian term is preceded by the number of the entry in which it is to be found in the Hungarian list (NB serial numbers are followed by a full stop in Hungarian spelling).
} 
The Hungarian Versions of Two International Onomastic Terminological Glossaries 89

for 30 becenév, 35 mikrotoponima, 63 utcanév); when deemed necessary the original examples have been changed to different but functionally similar Hungarian names to avoid misinterpretation (see the examples for 22 utónév). Notes and suggestions given in the original glossary on meaning (e.g. 69 helynévállomány, 27 szentnév [= hagionima], 52 hegynév [= oronima]), on form (e.g. 34 anyanévi eredetü név [= matronimikum, metronimikon]), on use (e.g. 10 koronima, 14 köznevesült tulajdonnév, 68 helynév [= toponima]) and on the term's status as a proper name (e.g. 19 népnév [= etnonima], 31 lakossági név) have been kept; what is more, in some cases remarks on the interpretation or use of the English or Hungarian terms have also been added (e.g. 22 utónév, 49 -onima [utótag]). Notes were considered integral parts of the definitions; thus they have not been treated as separate units within the entries.

The Hungarian-English term index facilitates search according to Hungarian terms. In the first column of the index, Hungarian terms have been listed in alphabetical order; compound terms, in accordance with the practice of the indices in the UNGEGN Glossary, are given according to both their first and second constituents (e.g. személynévállomány and állomány, személynév-; dülönév and név, dülö-); synonymous terms are presented in all possible orders, while indicating synonymity, e.g. allonima (= névváltozat), névváltozat (= allonima) and változat, név- (= allonima). In the second column of the index, the English equivalent(s) of the Hungarian term(s) has (have) been provided. If the ICOS list offers more than one English equivalent to a Hungarian term(s), all English terms have been indicated in each case, e.g. helynév (=toponima), név, hely- (= toponima), toponima (= helynév) $\rightarrow$ place name, toponym. The number of the main entry or that of the crossreference including the Hungarian term(s) can be found in the third column of the index.

The quadrilingual list presents English-Hungarian-German-French term equivalents. Terms functioning as headwords in main entries and in cross-references as well as terms appearing in notes have all been provided. Establishing equivalencies between English and German terms was not problematic, as the English equivalents of the majority of German terms are indicated in the German version of the Glossary. The few German terms listed without English equivalents are headwords in cross-references, thus the quadrilingual list only notes them in parentheses after the headwords of the relevant main entries of the German glossary, e.g. Hydronym (= Gewässername), Hypokoristikon (= Kosename). The identification of the English equivalents of French terms was made possible by the comparison of definitions and through cross-checking the illustrative place-name examples given in the English and French glossaries. If the French glossary displays a single French equivalent for distinct, synonymous English terms, this term has been given next to all of the relevant English terms in the quadrilingual list, e.g. microtoponym, minor name $\rightarrow$ microtoponyme; Christian name, first name, forename, given name $\rightarrow$ prénom. The headwords of the surplus German and French entries have been listed next to the terms closest in meaning in the appropriate language with short explanations, see German Onym (adjectival form: onymisch); French onomasticien (concerning place names: toponymiste).

3. Main ambitions at UNGEGN. UNGEGN is one of the seven standing expert bodies working within the United Nations Economic and Social Council (ECOSOC). The committee started its work in 1959, first as a temporary body, which became permanent in 1973. In the present day it has over 400 members from more than 100 countries, 
mostly geographers, cartographers, linguists, historians, planners, surveyors and officials from state administrations. The main tasks of UNGEGN include raising public awareness of the importance of the standardization of geographical names; governing the processes of name standardization at an international level; working on terminological standardization concerning place names; elaborating the principles of the formation and use of official place names; defining the rules for the romanization of geographical names; promoting the establishment of national names authorities and encouraging their effective work; collecting, storing, maintaining and disseminating toponymic data with respect to place names already nationally standardized; compiling gazetteers and databases of geographical names; and providing training in the standardization of geographical names. The international standardization of official, written geographical names is based on the results of national standardization processes; decisions of the expert body in standardization activities are generally reached through consensus (UNGEGN; on the organizational structure of the committee, the principles of the standardization of geographical names, the model of name standardization promoted by UNGEGN in Hungarian, cf. BÖLCSKEI 2012a; on the changing principles and terms adopted in the standardization of geographical names in Hungary, cf. BÖLCSKEI 2012c.).

To stimulate the successful implementation of the standardization of geographical names in different countries, UNGEGN has published two manuals on the theory and practice of names standardization processes. The volume entitled Manual for the National Standardization of Geographical Names includes the detailed description of a model of names standardization, compiled based on the "best practices" of countries that have achieved considerable goals in the standardization of geographical names at a national level (Manual 2006); and the volume entitled "Technical reference manual for the standardization of geographical names", which offers practical help in the romanization of place names of languages with non-Roman or non-alphabetic writing systems; in the precise transfer of toponymic data in an international context; and in the dissemination of the official English and national names of the countries of the world (Manual 2007).

3.1. Terminology work at UNGEGN and the Glossary promoting the use of standardized terms in the standardization of geographical names. The publication of the above mentioned two manuals was preceded by the compilation of a Glossary presenting and defining terms used frequently in the processes of the standardization of geographical names (UNGEGN Glossary). This Glossary was published in the six official languages of the United Nations (English, Arabic, French, Chinese, Russian, Spanish), and, by and large, served as the basis of term use in the two manuals.

The predecessor of this Glossary was the 1984 document entitled Glossary No. 330: Technical Terminology Employed in the Standardization of Geographical Names, edited by H. A. G. LEWIS, which listed and defined 175 terms for 115 topic related concepts in the six languages mentioned above. Its revised version was published in 1987, with the same title, under the reference Glossary No. 330/Rev ${ }^{2}$ (RAPER 2000: 194; KERFOOT 2000: 205). This latter term list was translated into Hungarian by ERVIN FöLDI, and was published in the onomastic journal Névtani Értesitö, accompanied by a paper on the practice of the standardization of geographical names within the United Nations (FöLDI 1992a, 1992b). However, in 1989 the 14th UNGEGN Session decided that the six language list was in need of revision, as it was considered incomplete with respect to the 
The Hungarian Versions of Two International Onomastic Terminological Glossaries 91

topic concerned, included several repetitions, while its definitions did not examine the peculiarities of non-Roman writing systems and non-European languages.

UNGEGN initiated the establishment of a working group on toponymic terminology, convened by Naftali Kadmon (Israel), who also led the work on the revision of the term list. In 1991, at the 15th UNGEGN Session, the working group presented the first draft of the revised term glossary, which contained 336 terms and their definitions in English, with illustrative place-name examples from 16 languages and writing systems. In 1992, at the 16th UNGEGN Session, delegates decided that the constant functioning of the working group on toponymic terminology was desirable, and allocated it the task of editing and periodically revising the Glossary of Terms for the Standardization of Geographical Names, which is accessible in the official languages of the United Nations. In 1998, at the 7th UNCSGN Conference, the working group presented the latest and extended version of the Glossary. This version, containing 375 terms in six languages, was published in New York by the United Nations Department of Economic and Social Affairs Statistics Division as an UNGEGN document in 2002 (GTSGN). The editor of the Glossary was NAFTALI KADMON, and its compilation and translation was carried out by the members of the Working Group on Toponymic Terminology on a voluntary basis.

The present duty of the Working Group is to continuously modernize the Glossary in light of the latest innovations in sciences and changes in languages. To fulfil this obligation, an Addendum (AGTSGN), which contains the revised definitions of 6 previously defined terms as well as the first definitions of 17 newly adopted terms in English, was drawn up in 2007, and translated into all six official languages of the United Nations. The current 2015 (pdf) version of the Glossary available on the UNGEGN website is the result of the compilation of the 2002 Glossary and the 2007 Addendum into a single document (UNGEGN Glossary). (For the linguistic analysis of the Glossary and the Addendum, cf. BÖLCSKEI 2012b.)

Besides the six official languages of the United Nations, the Glossary has been adapted into several other national languages, including German (JORDAN-BEINSTEIN 2011), Czech (ČÚZK trans. 2013) and Polish (ŁUKASIK trans. 2014); the 2012 Korean version can also be downloaded from the UNGEGN website (UNGEGN Glossary Korean).

The activity of the Working Group on Toponymic Terminology is, on the one hand, strongly connected to the realization of the fact that the successful implementation of the main ambitions of UNGEGN is dependent on the introduction and promotion of a consistent use of a standardized and harmonized terminology with respect to the standardization of geographical names (UNGEGN Brochure). While, on the other hand, is in accordance with recent trends in stressing the importance of the international standardization of terminology in different branches of science. Since 2008, the Working Group, whose current convenor is Staffan Nyström (Sweden), in part due to personal connections, has been actively co-operating with the ICOS Terminology Group (cf. NYSTRÖM 2014).

3.2. The Hungarian version of the UNGEGN Glossary. The first draft of the Hungarian version of the UNGEGN Glossary was prepared in 2013 at the Department of Hungarian Linguistics of Károli Gáspár University of the Reformed Church in Hungary, through teamwork involving MA students of Terminology (namely, Dóra Miklódy, Ágnes Horváth, Ilona Erzsébet Nagy, Zsófia Szonja Sajermann and Julianna Varga; project leader: Andrea Bölcskei; cf. BÖLCSKEI 2013a). Its proofread version is aimed at 
helping the standardization processes of Hungarian geographical names both in Hungary and in the regions of the neighbouring countries with ethnic Hungarian populations (on the latter issue see SZABÓMIHÁLY 2007, 2009, 2013; CSOMORTÁNI 2014).

The work process had to consider that the original Glossary aspires to adopt a fairly complex terminological principle and attempts to solve terminological problems in professional communication by removing geographical and language barriers (cf. BUDIN 2001: 14-17). It offers a theoretical background that can easily be shared by experts from different countries, and can also be easily modified according to the needs, languages and mother tongues of the said experts. Thus, the compilers of the Glossary - in accordance with modern terminographic principles (see CABRÉ 2003: 183) - describe terminological units with respect to their cognitive, linguistic and communicative components. The preparation of the Hungarian version of the Glossary was a dual task: on the one hand, the fundamental international approach of the original Glossary had to be preserved; on the other hand, its terms had to be adjusted to the characteristics of the Hungarian language and to the traditionally developed practices of Hungarian term use.

The underlying principles of the Hungarian version of the UNGEGN Glossary are very much similar to those adopted in the Hungarian version of the ICOS term list, mentioned above. In detail: when identifying the Hungarian equivalent(s) of English terms, the Hungarian version tends towards a compromise between the requirements of international intelligibility and Hungarian flavour. Thus, in cases when a traditionally used term of Hungarian origin is more common, it has been listed as the first equivalent, followed in parentheses by the synonymous term of an international background after an equality sign, e.g. 017 személynév (= antroponima), 021 kétnyelvüség (= bilingvizmus), 064 mellékjel (= diakritikus jel), 129 útnév (= hodonima). If the Hungarian form of a term of an international background is used more frequently in professional communication than the equivalent term of Hungarian origin, the terms have been enumerated in reverse order, e.g. 007 allofón (= hangváltozat), 099 firmware (= belsö vezérlöprogram), 171 ligatúra (= ikerbetü).

If only terms of native language origin (e.g. 280 latin betüs átírás) or of an international background have become accepted in Hungarian (e.g. $047 \mathrm{kreol}, 142$ interfész), only these have been given as equivalents. Presumable Hungarian term gaps have been eliminated by way of translation (e.g. 104 full title $\rightarrow$ teljes megnevezés, 299 short form [of a name] $\rightarrow$ rövid névforma), or by means of developing the Hungarian form of the term of an international background (e.g. B118 geonym $\rightarrow$ geonima). When required, these two methods have been combined, e.g. 277 retranszkripció (= kiejtés szerinti átirás visszaalakitása), 278 retranszliteráció (= betü szerinti átírás visszaalakítása). In the case of English terms of noun/adjective + noun structure, which can denote several distinct grammatical or semantic relations, it often seemed practical to create, in light of their definitions, Hungarian terms that are much more explicit than the English ones, e.g. 372 vowel marker = magánhangzó-jelölö kiegészítö írásjegy; 015 alphabetic sequence rules $=$ betürendet meghatározó szabályok; 342 toponymic guidelines = helynév-egységesítési irányelvek.

In identifying English-Hungarian term equivalents special attention has been paid to the fact that languages can denote reality in several ways, thus the terminological vocabulary of languages can be different as well (see KLAUDY 1997²:117). Sometimes an English term, depending on its distinct meanings, has two separate Hungarian equivalents, 
The Hungarian Versions of Two International Onomastic Terminological Glossaries 93

e.g. 344 toponymy = (a) helynévtan, helynévkutatás (= toponomasztika); and (b) helynévállomány. In other cases, two synonymous English terms of (partly) different forms can be rendered with a single Hungarian equivalent, e.g. 269 proper name and 270 proper noun = tulajdonnév; 032 composite name and 033 compound name = összetett név; 185 man-made feature and 048 cultural feature = mesterséges alakulat; 265 place name index and 343 toponymic index = helynévmutató. Rarely, synonymous English terms have synonymous Hungarian term equivalents, e.g. 173 linguistic area $=$ nyelvterület and 175 linguistic region = nyelvi régió. In a special case, the English term indicating a comprehensive concept has a Hungarian equivalent which, at the same time, is the hyperonym of two other related Hungarian terms, as explained in the definition, e.g. 001 acronym $\rightarrow$ mozaikszó (= akronima), an umbrella term in Hungarian for betüszó and szóösszevonás.

English and Hungarian terms used as equivalents in specialized communication at times reflect very different perspectives, e.g. 110 generic element $\rightarrow$ földrajzi köznévi elem, 112 generic term = földrajzi köznév. A few "false friend" terms have also been identified, e.g. 003 allograph = allográf (= iráselem-változat, betüváltozat 'type font'), and not más által írott 'written by someone else' (cf. allográf végrendelet 'self-proved will'); 005 allonym = névváltozat 'name variety' (= allonima), and not álnév 'pseudonym'; 368 vocalization = magánhangzó-jelölés 'indication of vowels in defective alphabetic scripts', and not vokalizáció 'change of a consonant into a vowel'. Information gained from definitions often proved to be crucial in the successful identification or formation of appropriate Hungarian terms, e.g. 092 feature, natural = alakulat, természetes: " $\rightarrow$ [t]opographic feature not made or significantly modified by man"; 093 feature, physical = alakulat, természeti: "Any $\rightarrow$ topographic feature that can be observed visually". Should a Hungarian term appear in different forms, the more frequently used version has been listed in the Hungarian glossary, e.g. 364 vektoros mód, and not vektormód.

Term groups have been rendered with the intention of preserving their connections, see, for instance, the terms ending in -gram $\rightarrow$-gram $\sim$-gramma (= -jel) 'sign', or including the element script $\rightarrow$ irás, írásrendszer 'writing (system)', e.g. 257 phonogram $\rightarrow$ fonogramma (= hangjel), 134 ideogram $\rightarrow$ ideogramma (= képírásjel), 179 logogram $\rightarrow$ logogram (= szójel), 326 syllabogram $\rightarrow$ szillabogram (= szótagjel); and 061 defective alphabetic script $\rightarrow$ hiányos betüirás, 075 donor script $\rightarrow$ átadó írás, 182 logographic script $\rightarrow$ szójelölö irás, 208 multiscriptual map $\rightarrow$ több írásrendszerü térkép, 189 map script $\rightarrow$ térképi írás.

The main entries have been edited to indicate the interdependence of the definitions in respect to meaning and form as found in the original Glossary (e.g. references to complementary terms; explanations discussing the logical relations of term meanings; definitions assisting each other's interpretation or that are textually parallel); and to respect the perspective of the original definitions (e.g. more general or more specific definitions than the ones consensually accepted in the relevant branches of science). Background knowledge of the basics of linguistics, geography, cartography and informatics seemed vital to the formulation of certain definitions. A cross-reference, instead of a definition, gives the English headword as well as the number of the main entry presenting the meaning in parentheses. 
Different translation strategies were adopted regarding examples based on the characteristics and on the function of the illustrative place names within the entries. In some cases, it was deemed desirable to keep the place names as they appear in the English text, e.g. Kaapstad and Cape Town as illustrative examples for the term 228 name, standardized $\rightarrow$ név, egységesitett (= standardizált). In other cases, to illustrate the meaning of a term, the Hungarian form has also been given in parentheses next to a native language place name, e.g. Al-Mamlakah al-Hāshimìyah al-Urdunīyah (Jordán Hásimita Királyság) to explain the term 183 long form (of a name) $\rightarrow$ teljes névforma. It was also desirable to give additional explanations to place-name examples in certain cases, e.g. in the case of entry A240 nominative form (of a toponym) $\rightarrow$ helynév (= toponima) alanyesete; to add illustrative Hungarian place names to the original set of examples, e.g. in the case of the entry 081 exonym $\rightarrow$ exonima; or, because of the different features of languages, to exchange the original example for a Hungarian one, e.g. in the case of the entry 201 morpheme $\rightarrow$ morféma.

The form of the Hungarian version is identical with that of the other non-English versions of the original Glossary. In the Hungarian term list, entries consist of an identification number, the English term as a headword, followed by the Hungarian equivalent(s) and the definition, or the reference. The sequence of the entries in the Hungarian version is thus determined by the alphabetic order of the English headwords, as in other foreign language versions. To enhance practicality, the six revised definitions provided in the Addendum have been observed. Similarly, terms newly defined in the 2007 list were inserted in their alphabetically appropriate places within the 2002 Glossary. In accordance with the English glossary, compound terms have been listed according to both their first and second elements together with their Hungarian term equivalents, which have been treated the same way. As the English terms constitute a part of the Hungarian glossary, explanations for the use of some English terms provided in the original Glossary have also been included in the Hungarian version. Retrieval of Hungarian terms is guaranteed by the alphabetical Hungarian-English term index at the end of the Hungarian glossary. (For a detailed description of the principles adopted in the preparation of the Hungarian version of the Glossary with respect to the pre-proof draft, cf. BÖLCSKEI 2013b.)

The Hungarian translation was based on the English Glossary. However, the Hungarian text has also been checked against the French, Spanish and Russian versions with the help of language advisers (Borbála Vitányi, Mária Tóth and Mariann Slíz, respectively). To confirm the reliability of the definitions and the adequacy of English-Hungarian term harmonization, expert proof-readers were invited from the fields of linguistics (Eszter B. Papp, LEG Hungary Ltd.; Gábor Mikesy, FÖMI Institute of Geodesy, Cartography and Remote Sensing); geography (Tibor Tiner, Hungarian Academy of Sciences, Research Centre for Astronomy and Earth Sciences, Geographical Institute); cartography (Mátyás Márton, Eötvös Loránd University, Department of Cartography and Geoinformatics); engineering, informatics (László Kovács, TÉK Localizations Ltd.) and economy (Imre Perger, MÁV-START Ltd.). Furthermore, a discussion was held with an administrative adviser (Elemér Györpál, Ministry of Interior, Department of Local Governments and Economic Affairs). If necessary, corrections and comments by field experts were included in the text, and this revised version was sent for a final proof-read to Ervin Földi (former President of FNB Hungarian Committee on Geographical Names) and Béla Pokoly (Senior Adviser, FNB Hungarian Committee on Geographical Names), who, as 
The Hungarian Versions of Two International Onomastic Terminological Glossaries 95

formerly and currently active participants in the activities of UNGEGN, have a deep knowledge of the standardization of geographical names (see above). Following the implementation of the majority of the modifications proposed by them, the Hungarian glossary reached its present form. The publication of the Hungarian version of the Glossary in the present volume was authorized by the Secretary of the UN Publications Board and Exhibits Committee on 12th June 2015.

4. Conclusion. When producing the Hungarian versions of the ICOS list and the UNGEGN Glossary, the goal of the editors was to combine scientific accuracy, clarity and practicability; to respect the themes and the approach of the source documents; and also to pay attention to the features of actual term use in the appropriate special language registers of the Hungarian language. The two term lists and the related indexes are published below in the hope that both experts and novices interested in the discipline of onomastics will be able to use them with ease to achieve the best possible results.

\section{Internet Resources}

AGTSGN. 2007. = KADMON, NAFTALI ed., Addendum for Glossary of Terms for the Standardization of Geographical Names. ST/ESA/STAT/SER.M/85/Add.1. United Nations, New York. http://unstats.un.org/unsd/geoinfo/UNGEGN/docs/pubs/glossary_add_e.pdf

ČÚZK trans. 2013. Slovník toponymické terminologie pro standardizaci geografických jmen. Verze 1.02. Názvoslovná komise ČÚZK, Praha. http://www.cuzk.cz/Zivotni-situace/Poradci-aporadni-organy/Nazvoslovna-komise-CUZK/Geograficke-nazvoslovne-seznamy.aspx

Glossary No. 330/Rev ${ }^{2}=$ Technical Terminology Employed in the Standardization of Geographical Names. ST/CS/SER.F/330/Rev.2. United Nations, 1987. http://unstats.un.org/unsd/geoinfo/ UNGEGN/docs/pubs/ST_CS_SER.F_330_Rev.2.pdf

GTSGN. 2002. = KADMON, NAFTALI ed., Glossary of Terms for the Standardization of Geographical Names. ST/ESA/STAT/SER.M/85. United Nations, New York. http://unstats.un.org/unsd/geoinfo/ UNGEGN/docs/glossary.pdf

Icosweb $=\underline{\text { http://icosweb.net/drupal/ }}$

Icosweb Terminology $=\underline{\text { https: } / / \text { icosweb.net } / \text { drupal/terminology }}$

Jordan, Peter - BeInstein, Bernd 2011. German Glossary of Toponymic Terminology, Third Edition. Twenty-sixth UNGEGN session, Vienna. http://unstats.un.org/unsd/geoinfo/UNGEGN/ docs/26th-gegn-docs/WP/WP66 Glossary.pdf

ŁUKASIK, MAREK transl. 2014. Stownik terminów używanych przy standaryzacji nazw geograficznych. Główny Urząd Geodezji i Kartografii, Warszawa. http://ksng.gugik.gov.pl/english/wydawnictwa.php

Manual 2006. = United Nations Group of Experts on Geographical Names ed., Manual for the national standardization of geographical names. ST/ESA/STAT/SER.M/88. Economic \& Social Affairs. United Nations, New York. http://unstats.un.org/unsd/publication/seriesm/seriesm 88e.pdf

Manual 2007. = United Nations Group of Experts on Geographical Names ed., Technical reference manual for the standardization of geographical names. ST/ESA/STAT/SER.M/87. Economic \& Social Affairs. United Nations, New York. http://unstats.un.org/unsd/geoinfo/UNGEGN/ docs/pubs/UNGEGN\%20tech\%20ref\%20manual m87 combined.pdf

UNGEGN = United Nations Group of Experts on Geographical Names. http://unstats.un.org/unsd/ geoinfo/UNGEGN/default.html 
UNGEGN Brochure $=$ http://unstats.un.org/unsd/geoinfo/UNGEGN/docs/pubs/UNGEGNbrochure en.pdf UNGEGN Bulletin 35 = http://unstats.un.org/unsd/geoinfo/UNGEGN/docs/Bulletin/ungegnbulletin35.pdf

UNGEGN Glossary = KADMON, NAFTALI ed., Glossary of Terms for the Standardization of Geographical Names (Revised). http://unstats.un.org/unsd/geoinfo/UNGEGN/docs/pdf/Glossary of terms_revised.pdf

$\mathrm{UNG \overline {G }} \overline{\bar{G}}$ Glossary Korean = 지명 표준화를 위한 용어 사전 Glossary of Terms for the Standardization of Geographical Names. National Geographic Information Institute, Republic of Korea. http://unstats.un.org/unsd/geoinfo/UNGEGN/docs/pdf/Glossary final.pdf

\section{Bibliography}

BöLCSKEI, ANDREA 2012a. Helynevek standardizációja: alapelvek, terminológiai kérdések a nemzetközi és a magyar gyakorlatban [Standardization of Geographical Names: Principles, Terminological Questions in International and Hungarian Practice]. Helynévtörténeti Tanulmányok 7: $85-102$.

BÖLCSKEI, ANDREA 2012b. A helynév-standardizáció terminológiájáról [On the Terminology of Geographical Names Standardization]. Névtani Értesitö 34: 167-178.

BÖLCSKEI, ANDREA 2012c. Changing principles, changing terms in the history of geographical names standardization in Hungary. Lecture presented at Trends in Toponymy 5. Bern, July 10, 2012.

BöLCSKEI, ANDREA 2013a. Az „UNGEGN Glossary of Terms for the Standardization of Geographical Names" címü terminusjegyzék magyar változatának elkészítéséről [On Preparing the Hungarian Version of the UNGEGN Document Entitled "Glossary of Terms for the Standardization of Geographical Names"]. Névtani Értesitö 35: 11-21.

BÖLCSKEI, ANDREA 2013b. Challenges in updating the Hungarian terminology for geographical names standardization. Magyar Terminológia 6/2: 153-168. https://doi.org/10.1556/1206.2013.6.2.3

Budin, GERHARD 2001. A critical evaluation of the state-of-the-art of terminology theory. ITTF Journal 12/1-2: 7-23.

CABRÉ, TERESA 2003. Theories of Terminology: their description, prescription and explanation. Terminology 9/2: 163-199. https://doi.org/10.1075/term.9.2.03cab

CSOMORTÁNI, MAGDOLNA 2014. A romániai magyar kisebbségi helységnév a nyelvi tervezés érdeklődési körében [Hungarian Minority Settlement Names in Romania in Relation to Language Planning]. Névtani Értesitö 36: 81-93.

FARKAS, TAMÁS 2012. Szempontok a magyar névtani terminológia megítéléséhez [On Some Characteristics and Problems of Hungarian Onomastic Terminology]. Névtani Értesitö 34: 139-148.

FARKAS, TAMÁS 2014. Onomastic Terminology in Hungarian - Situation, Problems and Needs. In: Tort i Donada, Joan - Montagut i Montagut, Montserrat eds., Els noms en la vida quotidiana. Actes del XXIV Congrés Internacional d'ICOS sobre Ciències Onomàstiques. I Names in daily life. Proceedings of the XXIV ICOS International Congress of Onomastic Sciences. Biblioteca Tècnica De Política Lingüística 11. Barcelona: Generalitat de Catalunya. 14-20. http://www.gencat.cat/llengua/BTPL/ICOS2011/003.pdf \& https://doi.org/10.2436/15.8040.01.3

FARKAS, TAMÁs 2015. A nemzetközi névkutatás és magyar kapcsolatai [International Onomastics and its Hungarian Relations]. In: FARKAS, TAMÁS - SLíz, MARIANN eds., Magyar névkutatás a 21. század elején. Budapest: Magyar Nyelvtudományi Társaság; ELTE Magyar Nyelvtudományi és Finnugor Intézet. 23-47. 
The Hungarian Versions of Two International Onomastic Terminological Glossaries 97

FöLDI, ERVIN 1992a. Az ENSZ földrajzinév-egységesítési tevékenysége [Geographical Names Standardization by the UN]. Névtani Értesitö 14: 21-35.

FöLDI, ERVIN 1992b. ENSZ földrajzinév-egységesítési szakkifejezések szótára [UN Technical Terminology Employed in the Standardization of Geographical Names]. Névtani Értesitö 14: 127-138.

HARVALíK, MiLAN 2005. Towards a new millennium - towards a common onomastic terminology? In: Brylla, Eva - Wahlberg, Mats eds., Proceedings of the 21st International Congress of Onomastic Sciences. Uppsala 19-24 August 2002. Uppsala: Språk- och folkminnesinstitutet. 1: $160-171$

HarValík, Milan 2014. Towards a common onomastic terminology? The next step. In: TORT I Donada, Joan - Montagut i Montagut, Montserrat eds., Els noms en la vida quotidiana. Actes del XXIV Congrés Internacional d'ICOS sobre Ciències Onomàstiques. / Names in daily life. Proceedings of the XXIV ICOS International Congress of Onomastic Sciences. Biblioteca Tècnica De Política Lingüística 11. Barcelona: Generalitat de Catalunya. 21-25. http://www.gencat. cat/llengua/BTPL/ICOS2011/004.pdf \& https://doi.org/10.2436/15.8040.01.4

KerfoOt, HeLEN 2000. Wien or Vienna; Kalaallit Nunaat, Grønland or Greenland? Recent work and directions in geographical names standardization through the United Nations. Onoma 35: 199-213. https://doi.org/10.2143/ONO.35.0.574375

KLAUdy, Kinga $1997^{3}$. A forditás elmélete és gyakorlata. Angol, német, francia, orosz forditástechnikai példatárral [The Theory and Practice of Translation. With Collection of Examples of Translation Technology Concerning English, German, French and Russian Languages]. 3rd, revised edition. Budapest: Scholastica.

NYSTRÖM, STAFFAN 2014. The terminological work of UNGEGN and ICOS - a presentation and a comparison. In: TORT I DONADA, JOAN - MONTAGUT I MONTAGUT, MONTSERRAT eds., Els noms en la vida quotidiana. Actes del XXIV Congrés Internacional d'ICOS sobre Ciències Onomàstiques. I Names in daily life. Proceedings of the XXIV ICOS International Congress of Onomastic Sciences. Biblioteca Tècnica De Política Lingüística 11. Barcelona: Generalitat de Catalunya. 52-57. http://www.gencat.cat/llengua/BTPL/ICOS2011/008.pdf \& https://doi.org/10.2436/15.8040.01.8

RAPER, PETER E. 2000. Introduction to standardization of geographical names. Onoma 35: 187-198. https://doi.org/10.2143/ONO.35.0.574374

SLíz, MARIANN 2012. Terminusok keletkezése és változása [Appearance and Changes of Terms]. Névtani Értesitö 34: 149-156.

SZABÓMIHÁLY, GiZELLA 2007. Magyar neve? Szlovákiai magyar helységnevek standardizációs problémái [Standardization of Hungarian Settlement Names in Slovakia]. Névtani Értesitö 29: 189-200.

SZABÓMIHÁly, GIZELla 2009. A határon túli magyar helynevek standardizációs kérdései [Questions of Standardization of Hungarian Settlement Names Outside the Present Boundaries of Hungary]. Korunk 3/5: 95-99.

SZABÓMIHÁLY, GIZELla 2013. A szlovákiai magyar helységnevek standardizálásakor alkalmazott elvek [Principles of Hungarian Settlement Names Standardization in Slovakia]. In: BAUKO, JÁNOS - BENYOVSZKY, KRISZTIÁN eds., A tulajdonnevek a forditás és a kétnyelvüség kontextusában. Nitra: Univerzita Konštantína Filozofa v Nitre Fakulta stredoeurópskych štúdií. 54-67.

ANDREA BÖLCSKEI

ORCID: 0000-0003-2628-5297

KRE Károli Gáspár University of the Reformed Church in Hungary Institute of Hungarian Linguistic, Literary and Cultural Studies

Budapest, Hungary 



\section{Terminusjegyzékek

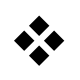 Glossaries of Terms}





\section{AZ ICOS TERMINUSJEGYZÉKE ÉS MUTATÓI THE ICOS LIST OF TERMS AND ITS INDICES}

\section{Alapvető névtani terminusok jegyzéke (Magyar változat) \\ List of Key Onomastic Terms (Hungarian Edition)}

Megjegyzés: a forrásként használt terminusjegyzék az angol nyelv vonatkozásában közöl néhány egységesített névtani szakkifejezést.

Note: The source document entitled List of Key Onomastic Terms lists a few standardized onomastic terms with respect to the English language.

\begin{tabular}{|c|c|c|c|}
\hline & Angol / English & Magyar / Hungarian & Definíció / Definiton \\
\hline & allonym & $\begin{array}{l}\text { névváltozat } \\
\text { (= allonima) }\end{array}$ & $\begin{array}{l}\text { Egy adott tulajdonnév azonos etimo- } \\
\text { lógiai eredetre visszavezethetô válto- } \\
\text { zata - pl.: a Joe a Joseph név- } \\
\text { változata. }\end{array}$ \\
\hline 02 & animal name & állatnév & Lásd: zoonym / állatnév (70). \\
\hline 03 & anthroponomasticon & $\begin{array}{l}\text { személynévszótár } \\
\text { (= antroponomasztikon) }\end{array}$ & $\begin{array}{l}\text { Személyneveket tartalmazó szótár, } \\
\text { illetve annak mentális vagy elméleti } \\
\text { megfelelöje. }\end{array}$ \\
\hline 04 & anthroponomastics & $\begin{array}{l}\text { személynévkutatás, } \\
\text { személynévtan } \\
\text { (= antroponomasztika) }\end{array}$ & $\begin{array}{l}\text { A névtan egy ága, amely a személy- } \\
\text { nevek tudományos igényü vizsgála- } \\
\text { tával foglalkozik. (Megjegyzés: a tu- } \\
\text { dományág jelölésére időnként az } \\
\rightarrow \text { anthroponymy terminust, illetve } \\
\text { adott nyelvü megfelelőit is használják, }\end{array}$ \\
\hline
\end{tabular}




\begin{tabular}{|c|c|c|}
\hline & & $\begin{array}{l}\text { e kifejezés használata azonban ebben } \\
\text { az értelemben nem javasolható.) }\end{array}$ \\
\hline 05 anthroponym & $\begin{array}{l}\text { személynév } \\
\text { (= antroponima) }\end{array}$ & $\begin{array}{l}\text { Egy adott személynek vagy szemé- } \\
\text { lyek egy csoportjának a tulajdonneve. }\end{array}$ \\
\hline 06 anthroponymy & személynévállomány & $\begin{array}{l}\text { Személynevek készlete egy adott } \\
\text { területen/régióban, nyelvben, idő- } \\
\text { szakban stb. (Megjegyzés: az } \\
\text { anthroponymy terminust, illetve } \\
\text { adott nyelvű megfelelőit időnként a } \\
\text { névtan személyneveket tudományos } \\
\text { igénnyel vizsgáló ágának jelölésére } \\
\text { is használják, ez azonban nem java- } \\
\text { solható.) }\end{array}$ \\
\hline 07 apellativisation & $\begin{array}{l}\text { köznevesülés, } \\
\text { köznévvé válás }\end{array}$ & $\begin{array}{l}\text { Lásd: deonymisation / köznevesülés, } \\
\text { köznévvé válás (15). }\end{array}$ \\
\hline 08 brand name & márkanév & $\begin{array}{l}\text { Egy adott márka tulajdonneve - pl.: } \\
\text { Toyota. }\end{array}$ \\
\hline 09 by-name & informális név & $\begin{array}{l}\text { Egy személy, hely, tárgy stb. infor- } \\
\text { mális, utólagosan adott tulajdonneve } \\
\text { - pl.: John Brown, más néven Shorty } \\
\text { az angolban; Juana Martinéz, más } \\
\text { néven Morena a spanyolban; Staffan } \\
\text { Nyström, más néven Lane a svéd- } \\
\text { ben; Big Apple, New York város és } \\
\text { Big Blue, az IBM cég informális } \\
\text { megjelölése az angolban. }\end{array}$ \\
\hline 10 choronym & koronima & $\begin{array}{l}\text { Egy nagyobb földrajzi terület vagy } \\
\text { közigazgatási egység tulajdonneve - } \\
\text { pl.: Afrika; Szibéria; Finnország; } \\
\text { Dalmácia; Toszkána; Bretagne; } \\
\text { Stájerország; Kasztília; La Mancha. } \\
\text { (Megjegyzés: Néhány nyelvben a } \\
\text { nagyobb kiterjedésü lakott területekkel } \\
\text { összefüggésben a } \rightarrow \text { macrotoponym } \\
\text { terminus adott nyelvü megfelelője } \\
\text { használatos; a magyarban a makro- } \\
\text { toponima általában a nagyobb } \\
\text { kiterjedésü területek megnevezésére, }\end{array}$ \\
\hline
\end{tabular}


s a településnevekre is használatban van. A magyarban a koronima terminus nem ismert, helyette a terminus által jelölt kategória alkategóriáinak a megnevezése vagy körülírás használatos a témától függően; pl. kontinens neve, országnév, tájnév.)

11 Christian name

keresztnév

12 cryptonym

fedőnév

(= kriptonima)

13 denominatum

megnevezett (= denotátum)

14 deonym

15 deonymisation

16 endonym

\section{köznevesült tulajdonnév}

köznevesülés, köznévvé válás

endonima
Lásd: first name / utónév (22).

Titkosító szándékkal használt tulajdonnév, melyet viselője védelme érdekében használnak.

A tulajdonnév viselője; személy, tárgy stb., amelyet egy adott tulajdonnévvel jelölnek, illetve szólítanak.

Köznév, amely egy tulajdonnévböl származik, vagy abból eredeztethető - pl.: az angol tweed 'skót gyapjúszövet' a Tweed folyó nevéből; a watt mértékegység a Watt családnévből; a spanyol quevedos 'egy szemüvegtípus' a Quevedo családnévböl; az asztúriai xuan 'ostoba, tökfilkó' a Xuan személynévböl. (Megjegyzés: számos nyelvben az $\rightarrow$ eponym terminus adott nyelvü megfelelője használatos ebben az értelemben.)

Az a folyamat, amely során egy tulajdonnév elveszíti tulajdonnévi funkcióját, illetve karakterét.

Egy földrajzi alakulat tulajdonneve egy olyan hivatalos vagy széles körben beszélt nyelven, amely azon a területen használatos, ahol maga az alakulat található - pl.: az olasz Venezia (nem pedig Velence), a cseh Praha (nem pedig Prága). 
17 eponym

18 ergonym

19 ethnonym

20 exonym eponima

ergonima

népnév

(= etnonima)

exonima
Egy személynek vagy személyek egy csoportjának, helynek, dolognak stb. a tulajdonneve, amely egy másik személy, család, hely, dolog stb. tulajdonnevének alapjául szolgál pl.: Washinton személynév - Washington helynév; Albert személynév - Albert-tó helynév. (A magyarban e terminus kevéssé használatos.)

Egy termék vagy márka tulajdonneve. (Megjegyzés: Néhány nyelvben a chrematonym terminus, illetve annak megfelelője használatos ebben az értelemben, amelynek azonban tágabb jelentése is lehet, úgymint események, rendezvények, intézmények, szervezetek stb. tulajdonneve. A magyarban az összefoglaló értelmü terminus nem használatos.)

Egy etnikai csoportot (törzs, nép, klán stb.) vagy annak egy tagját jelölő tulajdonnév - pl.: olaszok, bajorok, horvát, francia, zulu. (Megjegyzés: A népnevek a magyarban nem számítanak tulajdonneveknek. Más nyelvekben, illetve egyes értelmezések szerint a népnevek egyes és többes számban is tulajdonneveknek minősülnek, míg egy másik megközelítés szerint csak többes számban tulajdonnevek, egyes számban köznevek.)

Egy adott nyelvben használt tulajdonnév, mellyel olyan földrajzi alakulatot jelölnek, amely kívül található azon a területen, ahol a kérdéses nyelvet széles körben beszélik, s amely név formájában különbözik a tulajdonnévtől, amelyet azon a területen használnak, ahol a földrajzi alakulat található - pl.: a francia 
21 family name

családnév

22 first name

23 field name

dülőnév

24 forename

utónév

25 geographical name

26 given name

egyénnév

27 hagionym

szentnév

(= hagionima)

28 hodonym

útnév

(= hodonima)
Londres az egyesült királyságbeli London azonosítására; a magyar Varsó a lengyelországi Warszawa azonosítására; az angol Bangkok a thaiföldi Krung Thep azonosítására; a spanyol Ginbera a svájci Genève azonosítására.

Egy család vagy egy ilyen névvel rendelkező családtag öröklődő tulajdonneve - pl.: Smith, Farkas, Neumann, Herrera.

Tulajdonnév, amelyet egy személy születésekor, keresztelésekor vagy életének más jelentős eseménye során kap - pl.: Gyula, Csaba, Bence, Gyöngyvér. (Megjegyzés: Az angol terminus az angolszász, illetve az indoeurópai típusú személynévsorrendet alkalmazó országokban, a magyar terminus a Magyarországon hivatalos személynév elemeinek sorrendje tekintetében értelmezendő. A használatban ezért szokásos még a $\rightarrow$ Christian name / keresztnév és a $\rightarrow$ given name / egyénnév.)

Egy kisebb, mezőgazdasági célokra használt földdarab tulajdonneve.

Lásd: first name / utónév (22).

Lásd: toponym / helynév (= toponima) (68).

Lásd: first name / utónév (22).

Szentek tulajdonneve. (Megjegyzés: a terminus szent helyek és tárgyak nevével összefüggésben nem használható.)

Utaknak adott tulajdonnév (azaz egy adott utca, tér, autópálya, országút, 
29 hydronym

30 hypocoristic

31 inhabitant name

32 last name

33 macrotoponym

34 metronym víznév (= hidronima)

becenév

lakossági név

vezetéknév

makrotoponima

anyanévi eredetü név (= matronimikum, metronimikon) gyalogút, alagút, gázló, híd, gyaloghíd, vasútvonal stb. tulajdonneve) pl.: Portobello Road, Marktgasse, Via Baltica, D1, Csalagút, Andrássy út, Hösök tere.

Egy adott víztestnek, víztömegnek a tulajdonneve (azaz egy adott tenger, öböl, tengerszoros, tó, mocsár, halastó, víztározó, csermely, forrás, folyó, patak, vízesés stb. tulajdonneve) pl.: Atlanti-óceán, Balti-tenger, Oroszlán-öböl, Felső-tó, Sárgafolyó, Niagara-vizesés.

Egy tulajdonnév informális, érzelmi töltetet hordozó formája, amely a személynévből származik morfológiai változtatás(ok) eredményeként pl.: a magyarban Ricsi a Richárd helyett; a lengyelben Iza az Izabella helyett; a spanyolban Nacho az Ignacio helyett; a horvátban Ivica az Ivan helyett.

Egy adott régió, ország, város, falu stb. lakosára vonatkozó tulajdonnév - pl.: Liepziger 'lipcsei lakos' a németben; Londoner 'londoni lakos' az angolban. (Megjegyzés: a magyarban és még néhány más nyelvben, továbbá egyes tudósok vélekedése szerint a lakossági név nem számít tulajdonnévnek - pl.: madrileño 'madridi lakos' a spanyolban.)

Lásd: family name / családnév (21).

Lásd: choronym / koronima (10).

Az anya tulajdonnevéből származó személynév - pl.: Tilgner (a Tilg[e] becenévből, amely az Ottilie személynévből származik) a németben; 
Haničinec (a Hana személynévből) a csehben. (Megjegyzés: a matronimikon forma használata nem javasolható.)

35 microtoponym mikrotoponima

36 minor name

37 name

38 name bearer

39 namegiver

40 namegiving

névadás

$\begin{array}{lll}41 \text { naming } & \text { névadás } \\ 42 \text { nesonym } & \text { szigetnév } \\ 43 \text { nickname } & \text { ragadványnév }\end{array}$

Tulajdonnév, amely kisebb objektumokra vonatkozik - pl.: dülők, legelők, kerítések, kövek, mocsarak, zsombékok, árkok stb. neve. A mikrotoponimákat általában az emberek egy korlátozott számú csoportja használja helyben - pl.: Lange Wiese (legelö), Further Piece (dülő), Csesz-árok, Nekeresd (legelö).

Lásd: microtoponym / mikrotoponima (35).

Lásd: proper name / tulajdonnév (57).

\section{Lásd: denominatum / megnevezett} (= denotátum) (13).

Személy, közösség, hatóság vagy intézmény, amely (más) személyeket, helyeket, tárgyakat stb. elnevez.

Folyamat vagy esemény, melynek során egy személy, hely vagy dolog tulajdonnevet kap - pl.: gyermek születése; hajó elnevezése.

Lásd: namegiving / névadás (40).

Egy adott sziget tulajdonneve.

Egy adott személy informális, utólagosan adott tulajdonneve, amely általában jellemzi öt - pl.: The Governator, Arnold Schwarzenegger ragadványneve az Egyesült Államokban. (Megjegyzés: e névtípus a $\rightarrow$ by-name / informális név alkategóriáját alkotja.) 
44 odonym

45 oikonym

46 onomastician

47 onomasticon

48

onomastics

49

onym

50 onymisation

51 onymy

52 oronym útnév

(= hodonima)

településnév

névkutató

névszótár

(= onomasztikon)

névtan, névkutatás, névtudomány (= onomasztika)

-onima (utótag)
Lásd: hodonym / útnév (= hodonima) (28). (Megjegyzés: az odonym terminus használatát a jegyzék készítői nem javasolják.)

Lásd: settlement name / településnév (61).

Személy, aki a tulajdonnevek tudományos igényü tanulmányozásával foglalkozik.

Neveket tartalmazó szótár, illetve annak mentális vagy elméleti megfelelője.

A tulajdonneveket tudományos igénnyel vizsgáló tudományág.

Lásd: proper name / tulajdonnév (57). (Megjegyzés: Az angol szaknyelvben e terminust - és több más nyelvben hasonlóképpen - önálló szóként is használják a tulajdonnév jelölésére. A magyarban az -onima utótag leggyakrabban bizonyos típusú tulajdonneveket összefoglaló jelleggel jelölő terminusok esetében használatos.)

Egy adott nyelvi elem (ide értve a közneveket, mellékneveket, igéket, indulatszavakat, szókapcsolatokat stb.) átvitele a tulajdonnevek osztályába.

tulajdonnevesülés (= onimizáció)

névállomány

Egy adott régióban, nyelvben, időszakban stb. használatos tulajdonnevek készlete.

A terep egy megemelkedett képződményének a tulajdonneve (azaz egy hegynek, hegyláncnak, fennsíknak, felföldnek, dombnak, szirtnek stb. 
53 patronym

54 personal name

55 place name

56 product name

57 proper name

58 proprialisation

59 pseudonym

60 psychoonomastics apanévi eredetü név (= patronimikum, patronimikon)

személynév (= antroponima)

helynév (= toponima)

terméknév

tulajdonnév

névvé válás, tulajdonnévvé válás, tulajdonnevesülés (= onimizáció)

álnév (= pszeudonima)

Egy személy kitalált, felvett tulajdonneve; általában művészek, politikusok stb. használják a hivatalos nevük alternatívájaként.

A névtan ága, amely a neveket pszicholingvisztikai szempontból vizsgálja. 
61 settlement name településnév

62 socioonomastics

szocioonomasztika

63 street name

64 surname

65 theonym

66 toponomasticon

67 toponomastics

\section{vezetéknév}

istennév

(= teonima)

helynévszótár

(= toponomasztikon)

helynévkutatás, helynévtan (= toponomasztika)
Bármely típusú emberi település (nagyvárosok, városok, falvak, tanyák, farmok, házak stb.) tulajdonneve - pl.: Párizs, Turku, Jokohama, $\dagger$ Trója, Nofim (ház). (Megjegyzés: a magyar terminus szükebb jelentésü: nagyvárosok, városok, községek és falvak tulajdonnevére használatos.)

A névtan egy ága, amely a tulajdonneveket szociolingvisztikai szempontból vizsgálja.

Egy adott közlekedési útvonal tulajdonneve egy nagyvárosban, városban vagy faluban - pl.: Broadway, the Strand, Baker Street, Ady Endre utca, Váci utca. (Megjegyzés: A $\rightarrow$ hodonym / útnév (= hodonima) típusának alkategóriáját alkotják. A magyarban e terminus nemcsak az utak és utcák, hanem minden más típusú közterület - pl. köz, tér - tulajdonnevére is vonatkozik.)

Lásd: family name / családnév (21).

Egy isten, istennő vagy istenség tulajdonneve - pl.: Zeusz, Odin, Diana, Morana.

Helyneveket tartalmazó szótár, illetve annak mentális vagy elméleti megfelelöje.

A névtan egy ága, amely a helynevek tudományos igényü vizsgálatával foglalkozik. (Megjegyzés: a tudományág jelölésére időnként a $\rightarrow$ toponymy terminust, illetve adott nyelvü megfelelöit is használják; e kifejezés használata azonban ebben az értelemben nem javasolható.) 
68 toponym

69 toponymy

70 helynév

(= toponima)

helynévállomány

állatnév
Egy lakott vagy lakatlan hely tulajdonneve (így egy hegy, víztest, sziget, erdő, város, falu, dülő, legelö, utca, út stb. neve) - pl.: Uppsala, Földközitenger, Nyugalom tengere (terület a Holdon), Amazonis Planitia (terület a Marson), Mont Blanc, Szajna, Szardinia, Auckland. (Megjegyzés: a terminus szinonimájaként a $\rightarrow$ geographical name / földrajzi név terminus is használható, amennyiben a Földön lévő helyről van szó.)

Helynevek készlete egy adott területen/ régióban, nyelvben, időszakban stb. (Megjegyzés: a toponymy terminust, illetve adott nyelvü megfelelöit időnként a névtan helyneveket tudományos igénnyel vizsgáló ágának jelölésére is használják, ez azonban nem javasolható.)

Egy adott állat tulajdonneve - pl.: Fido, a kutya; Jumbo, az elefánt. 
Magyar-angol terminusmutató az ICOS-szójegyzékhez

$*$

Hungarian-English Term Index of the ICOS Glossary

\begin{tabular}{|c|c|c|}
\hline Magyar / Hungarian & Angol / English & \\
\hline adás, név- & namegiving, naming & 40,41 \\
\hline adó, név- & namegiver & 39 \\
\hline állatnév & animal name, zoonym & 02,70 \\
\hline állomány, helynév- & toponymy & 69 \\
\hline állomány, név- & onymy & 51 \\
\hline állomány, személynév- & anthroponymy & 06 \\
\hline $\begin{array}{l}\text { allonima } \\
\text { (= névváltozat) }\end{array}$ & allonym & 01 \\
\hline $\begin{array}{l}\text { álnév } \\
\text { (= pszeudonima) }\end{array}$ & pseudonym & 59 \\
\hline $\begin{array}{l}\text { antroponima } \\
\text { (= személynév) }\end{array}$ & anthroponym, personal name & 05,54 \\
\hline $\begin{array}{l}\text { antroponomasztika } \\
\text { (= személynévkutatás, } \\
\text { személynévtan) }\end{array}$ & anthroponomastics & 04 \\
\hline $\begin{array}{l}\text { antroponomasztikon } \\
\text { (= személynévszótár) }\end{array}$ & anthroponomasticon & 03 \\
\hline $\begin{array}{l}\text { anyanévi eredetű név } \\
\text { (= matronimikum, } \\
\text { metronimikon) }\end{array}$ & metronym & 34 \\
\hline $\begin{array}{l}\text { apanévi eredetủ név } \\
\text { (= patronimikum, } \\
\text { patronimikon) }\end{array}$ & patronym & 53 \\
\hline becenév & hypocoristic & 30 \\
\hline családnév & family name & 21 \\
\hline
\end{tabular}




\begin{tabular}{|c|c|c|}
\hline $\begin{array}{l}\text { denotátum } \\
(=\text { megnevezett) }\end{array}$ & denominatum & 13 \\
\hline dülőnév & field name & 23 \\
\hline egyénnév & given name & 26 \\
\hline endonima & endonym & 16 \\
\hline eponima & eponym & 17 \\
\hline ergonima & ergonym & 18 \\
\hline $\begin{array}{l}\text { etnonima } \\
\text { (= népnév) }\end{array}$ & ethnonym & 19 \\
\hline exonima & exonym & 20 \\
\hline $\begin{array}{l}\text { fedőnév } \\
\text { (= kriptonima) }\end{array}$ & cryptonym & 12 \\
\hline földrajzi név & geographical name & 25 \\
\hline $\begin{array}{l}\text { hagionima } \\
\text { (= szentnév) }\end{array}$ & hagionym & 27 \\
\hline $\begin{array}{l}\text { hegynév } \\
\text { (= oronima) }\end{array}$ & oronym & 52 \\
\hline $\begin{array}{l}\text { helynév } \\
\text { (= toponima) }\end{array}$ & place name, toponym & 55,68 \\
\hline helynévállomány & toponymy & 69 \\
\hline $\begin{array}{l}\text { helynévkutatás } \\
\text { (= toponomasztika) }\end{array}$ & toponomastics & 67 \\
\hline $\begin{array}{l}\text { helynévszótár } \\
\text { (= toponomasztikon) }\end{array}$ & toponomasticon & 66 \\
\hline $\begin{array}{l}\text { helynévtan } \\
\text { (= toponomasztika) }\end{array}$ & toponomastics & 67 \\
\hline $\begin{array}{l}\text { hidronima } \\
\text { (= víznév) }\end{array}$ & hydronym & 29 \\
\hline $\begin{array}{l}\text { hodonima } \\
\text { (= útnév) }\end{array}$ & hodonym & 28 \\
\hline informális név & by-name & 09 \\
\hline $\begin{array}{l}\text { istennév } \\
\text { (= teonima) }\end{array}$ & theonym & 65 \\
\hline
\end{tabular}




\begin{tabular}{|c|c|c|}
\hline keresztnév & Christian name & 11 \\
\hline koronima & choronym & 10 \\
\hline köznevesülés & apellativisation, deonymisation & 07,15 \\
\hline köznevesült tulajdonnév & deonym & 14 \\
\hline köznévvé válás & apellativisation, deonymisation & 07,15 \\
\hline $\begin{array}{l}\text { kriptonima } \\
\text { (= fedönév) }\end{array}$ & cryptonym & 12 \\
\hline $\begin{array}{l}\text { kutatás, helynév } \\
\text { (= toponomasztika) }\end{array}$ & toponomastics & 67 \\
\hline $\begin{array}{l}\text { kutatás, név- } \\
\text { (= onomasztika) }\end{array}$ & onomastics & 48 \\
\hline $\begin{array}{l}\text { kutatás, személynév- } \\
\text { (= antroponomasztika) }\end{array}$ & anthroponomastics & 04 \\
\hline kutató, név- & onomastician & 46 \\
\hline lakossági név & inhabitant name & 31 \\
\hline makrotoponima & macrotoponym & 33 \\
\hline márkanév & brand name & 08 \\
\hline $\begin{array}{l}\text { matronimikum } \\
\text { (= anyanévi eredetủ név) }\end{array}$ & metronym & 34 \\
\hline $\begin{array}{l}\text { megnevezett } \\
\text { (= denotátum) }\end{array}$ & denominatum & 13 \\
\hline $\begin{array}{l}\text { metronimikon } \\
\text { (= anyanévi eredetủ név) }\end{array}$ & metronym & 34 \\
\hline mikronév & minor name & 36 \\
\hline mikrotoponima & microtoponym & 35 \\
\hline $\begin{array}{l}\text { népnév } \\
\text { (= etnonima) }\end{array}$ & ethnonym & 19 \\
\hline név & name & 37 \\
\hline $\begin{array}{l}\text { név, ál- } \\
\text { (= pszeudonima) }\end{array}$ & pseudonym & 59 \\
\hline név, állat- & animal name, zoonym & 02,70 \\
\hline
\end{tabular}




\begin{tabular}{|c|c|c|}
\hline $\begin{array}{l}\text { név, anyanévi eredetű } \\
\text { (= matronimikum, } \\
\text { metronimikon) }\end{array}$ & metronym & 34 \\
\hline $\begin{array}{l}\text { név, apanévi eredetü } \\
\text { (= patronimikum, } \\
\text { patronimikon) }\end{array}$ & patronym & 53 \\
\hline név, bece- & hypocoristic & 30 \\
\hline név, család- & family name & 21 \\
\hline név, dülö- & field name & 23 \\
\hline név, egyén- & given name & 26 \\
\hline $\begin{array}{l}\text { név, fedő- } \\
\text { (= kriptonima) }\end{array}$ & cryptonym & 12 \\
\hline név, földrajzi & geographical name & 25 \\
\hline $\begin{array}{l}\text { név, hegy- } \\
\text { (= oronima) }\end{array}$ & oronym & 52 \\
\hline $\begin{array}{l}\text { név, hely- } \\
\text { (= toponima) }\end{array}$ & place name, toponym & 55,68 \\
\hline név, informális & by-name & 09 \\
\hline $\begin{array}{l}\text { név, isten- } \\
(=\text { teonima) }\end{array}$ & theonym & 65 \\
\hline név, kereszt- & Christian name & 11 \\
\hline név, lakossági & inhabitant name & 31 \\
\hline név, márka- & brand name & 08 \\
\hline név, mikro- & minor name & 36 \\
\hline $\begin{array}{l}\text { név, nép- } \\
\text { (= etnonima) }\end{array}$ & ethnonym & 19 \\
\hline név, ragadvány- & nickname & 43 \\
\hline $\begin{array}{l}\text { név, személy- } \\
\text { (= antroponima) }\end{array}$ & anthroponym, personal name & 05,54 \\
\hline $\begin{array}{l}\text { név, szent- } \\
\text { (= hagionima) }\end{array}$ & hagionym & 27 \\
\hline név, sziget- & nesonym & 42 \\
\hline név, település- & oikonym, settlement name & 45,61 \\
\hline név, termék- & product name & 56 \\
\hline
\end{tabular}




\begin{tabular}{|c|c|c|}
\hline név, tulajdon- & proper name & 57 \\
\hline $\begin{array}{l}\text { név, út- } \\
\text { (= hodonima) }\end{array}$ & hodonym (odonym) & 28,44 \\
\hline név, utca- & street name & 63 \\
\hline név, utó- & first name, forename & 22,24 \\
\hline név, vezeték- & last name, surname & 32,64 \\
\hline $\begin{array}{l}\text { név, víz- } \\
\text { (= hidronima) }\end{array}$ & hydronym & 29 \\
\hline névadás & namegiving, naming & 40,41 \\
\hline névadó & namegiver & 39 \\
\hline névállomány & onymy & 51 \\
\hline névállomány, hely- & toponymy & 69 \\
\hline névállomány, személy- & anthroponymy & 06 \\
\hline $\begin{array}{l}\text { névkutatás } \\
\text { (= onomasztika) }\end{array}$ & onomastics & 48 \\
\hline $\begin{array}{l}\text { névkutatás, hely- } \\
\text { (= toponomasztika) }\end{array}$ & toponomastics & 67 \\
\hline $\begin{array}{l}\text { névkutatás, személy- } \\
\text { (= antroponomasztika) }\end{array}$ & anthroponomastics & 04 \\
\hline névkutató & onomastician & 46 \\
\hline $\begin{array}{l}\text { névszótár } \\
\text { (= onomasztikon) }\end{array}$ & onomasticon & 47 \\
\hline $\begin{array}{l}\text { névszótár, hely- } \\
\text { (= toponomasztikon) }\end{array}$ & toponomasticon & 66 \\
\hline $\begin{array}{l}\text { névszótár, személy- } \\
\text { (= antroponomasztikon) }\end{array}$ & anthroponomasticon & 03 \\
\hline $\begin{array}{l}\text { névtan } \\
\text { (= onomasztika) }\end{array}$ & onomastics & 48 \\
\hline $\begin{array}{l}\text { névtan, hely- } \\
\text { (= toponomasztika) }\end{array}$ & toponomastics & 67 \\
\hline $\begin{array}{l}\text { névtan, személy- } \\
\text { (= antroponomasztika) }\end{array}$ & anthroponomastics & 04 \\
\hline $\begin{array}{l}\text { névtudomány } \\
\text { (= onomasztika) }\end{array}$ & onomastics & 48 \\
\hline
\end{tabular}




\begin{tabular}{|c|c|c|}
\hline $\begin{array}{l}\text { névváltozat } \\
\text { (= allonima) }\end{array}$ & allonym & 01 \\
\hline $\begin{array}{l}\text { névvé válás } \\
\text { (= onimizáció) }\end{array}$ & onymisation, proprialisation & 50,58 \\
\hline névviselö & name bearer & 38 \\
\hline -onima (utótag) & onym & 49 \\
\hline $\begin{array}{l}\text { onimizáció (= névvé válás, } \\
\text { tulajdonnévvé válás, } \\
\text { tulajdonnevesülés) }\end{array}$ & onymisation & 50 \\
\hline $\begin{array}{l}\text { onomasztika (= névtan, } \\
\text { névkutatás, névtudomány) }\end{array}$ & onomastics & 48 \\
\hline onomasztika, pszicho- & psychoonomastics & 60 \\
\hline onomasztika, szocio- & socioonomastics & 62 \\
\hline $\begin{array}{l}\text { onomasztikon } \\
\text { (= névszótár) }\end{array}$ & onomasticon & 47 \\
\hline $\begin{array}{l}\text { oronima } \\
\text { (= hegynév) }\end{array}$ & oronym & 52 \\
\hline $\begin{array}{l}\text { patronimikon } \\
\text { (= apanévi eredetű név) }\end{array}$ & patronym & 53 \\
\hline $\begin{array}{l}\text { patronimikum } \\
\text { (= apanévi eredetű név) }\end{array}$ & patronym & 53 \\
\hline $\begin{array}{l}\text { pszeudonima } \\
\text { (= álnév) }\end{array}$ & pseudonym & 59 \\
\hline pszichoonomasztika & psychoonomastics & 60 \\
\hline ragadványnév & nickname & 43 \\
\hline $\begin{array}{l}\text { személynév } \\
\text { (= antroponima) }\end{array}$ & anthroponym, personal name & 05,54 \\
\hline személynévállomány & anthroponymy & 06 \\
\hline $\begin{array}{l}\text { személynévkutatás } \\
\text { (= antroponomasztika) }\end{array}$ & anthroponomastics & 04 \\
\hline $\begin{array}{l}\text { személynévszótár } \\
\text { (= antroponomasztikon) }\end{array}$ & anthroponomasticon & 03 \\
\hline $\begin{array}{l}\text { személynévtan } \\
\text { (= antroponomasztika) }\end{array}$ & anthroponomastics & 04 \\
\hline
\end{tabular}




\begin{tabular}{|c|c|c|}
\hline $\begin{array}{l}\text { szentnév } \\
\text { (= hagionima) }\end{array}$ & hagionym & 27 \\
\hline szigetnév & nesonym & 42 \\
\hline szocioonomasztika & socioonomastics & 62 \\
\hline $\begin{array}{l}\text { szótár, helynév- } \\
\text { (= toponomasztikon) }\end{array}$ & toponomasticon & 66 \\
\hline $\begin{array}{l}\text { szótár, név- } \\
\text { (= onomasztikon) }\end{array}$ & onomasticon & 47 \\
\hline $\begin{array}{l}\text { szótár, személynév- } \\
\text { (= antroponomasztikon) }\end{array}$ & anthroponomasticon & 03 \\
\hline $\begin{array}{l}\text { tan, helynév- } \\
\text { (= toponomasztika) }\end{array}$ & toponomastics & 67 \\
\hline $\begin{array}{l}\text { tan, név- } \\
(=\text { onomasztika })\end{array}$ & onomastics & 48 \\
\hline $\begin{array}{l}\text { tan, személynév- } \\
\text { (= antroponomasztika) }\end{array}$ & anthroponomastics & 04 \\
\hline településnév & oikonym, settlement name & 45,61 \\
\hline $\begin{array}{l}\text { teonima } \\
\text { (= istennév) }\end{array}$ & theonym & 65 \\
\hline terméknév & product name & 56 \\
\hline $\begin{array}{l}\text { toponima } \\
\text { (= helynév) }\end{array}$ & place name, toponym & 55,68 \\
\hline toponima, makro- & macrotoponym & 33 \\
\hline toponima, mikro- & microtoponym & 35 \\
\hline $\begin{array}{l}\text { toponomasztika } \\
\text { (= helynévkutatás, } \\
\text { helynévtan) }\end{array}$ & toponomastics & 67 \\
\hline $\begin{array}{l}\text { toponomasztikon } \\
\text { (= helynévszótár) }\end{array}$ & toponomasticon & 66 \\
\hline $\begin{array}{l}\text { tudomány, név- } \\
\text { (= onomasztika) }\end{array}$ & onomastics & 48 \\
\hline tulajdonnév & proper name & 57 \\
\hline tulajdonnév, köznevesült & deonym & 14 \\
\hline
\end{tabular}




tulajdonnevesülés
(= onimizáció)
tulajdonnévvé válás
(= onimizáció)
utcanév
útnév
(= hodonima)
utónév
változat, név-
(= allonima)
vezetéknév
viselő, név-
víznév
(= hidronima)

onymisation, proprialisation

50,58

onymisation, proprialisation

50,58

(= onimizáció)

street name

63

hodonym (odonym)

28,44

first name, forename

22,24

allonym

01

last name, surname

32,64

name bearer

38

hydronym

29 


\section{Angol-magyar-német-francia terminusekvivalenciák mutatója az ICOS-szójegyzékhez \\ Index of the English-Hungarian-German-French Term Equivalents of the ICOS Glossary}

\begin{tabular}{|c|c|c|c|}
\hline Angol / English & Magyar / Hungarian & Német / German & Francia / French \\
\hline allonym & $\begin{array}{l}\text { névváltozat } \\
(=\text { allonima })\end{array}$ & Allonym & allonyme \\
\hline animal name & állatnév & Tiername & nom d'animal \\
\hline anthroponomasticon & $\begin{array}{l}\text { személynévszótár } \\
\text { (= antroponomasztikon) }\end{array}$ & Anthroponomastikon & anthroponomasticon \\
\hline anthroponomastics & $\begin{array}{l}\text { személynévkutatás, } \\
\text { személynévtan } \\
\text { (= antroponomasztika) }\end{array}$ & Anthroponomastik & anthroponymie \\
\hline anthroponym & $\begin{array}{l}\text { személynév } \\
\text { (= antroponima) }\end{array}$ & Anthroponym & anthroponyme \\
\hline anthroponymy & személynévállomány & Anthroponymie & anthroponymie \\
\hline apellativisation & $\begin{array}{l}\text { köznevesülés, } \\
\text { köznévvé válás }\end{array}$ & Appellativierung & appellativisation \\
\hline brand name & márkanév & Markenname & nom de marque \\
\hline by-name & informális név & Beiname & surnom \\
\hline choronym & koronima & Choronym & choronyme \\
\hline Christian name & keresztnév & Taufname & prénom \\
\hline cryptonym & $\begin{array}{l}\text { fedőnév } \\
\text { (= kriptonima) }\end{array}$ & $\begin{array}{l}\text { Kryptonym } \\
\text { (= Deckname) }\end{array}$ & cryptonyme \\
\hline denominatum & $\begin{array}{l}\text { megnevezett } \\
(=\text { denotátum })\end{array}$ & Denominatum & denominatum \\
\hline deonym & $\begin{array}{l}\text { köznevesült } \\
\text { tulajdonnév }\end{array}$ & $\begin{array}{l}\text { Deonym } \\
\text { (= Epotoponym) }\end{array}$ & déonyme \\
\hline deonymisation & köznevesülés, & Deonymisierung & déonymisation \\
\hline
\end{tabular}


Angol-magyar-német-francia terminusekvivalenciák mutatója...

\begin{tabular}{|c|c|c|c|}
\hline endonym & endonima & Endonym & endonyme \\
\hline eponym & eponima & Eponym & éponyme \\
\hline $\begin{array}{l}\text { ergonym } \\
\text { (= chrematonym) }\end{array}$ & ergonima & $\begin{array}{l}\text { Ergonym } \\
\text { (= Krematonym) }\end{array}$ & $\begin{array}{l}\text { ergonyme } \\
\text { (= chrématonyme) }\end{array}$ \\
\hline ethnonym & $\begin{array}{l}\text { népnév } \\
\text { (= etnonima) }\end{array}$ & Ethnonym & ethnonyme \\
\hline exonym & exonima & Exonym & exonyme \\
\hline family name & családnév & $\begin{array}{l}\text { Familienname } \\
\text { (= Zuname) }\end{array}$ & nom de famille \\
\hline first name & utónév & Vorname & prénom \\
\hline field name & dülönév & Flurname & nom de parcelle \\
\hline forename & utónév & Vorname & prénom \\
\hline geographical name & földrajzi név & $\begin{array}{l}\text { geographischer } \\
\text { Name }\end{array}$ & nom géographique \\
\hline given name & egyénnév & Vorname & prénom \\
\hline hagionym & $\begin{array}{l}\text { szentnév } \\
\text { (= hagionima) }\end{array}$ & Hagionym & hagionyme \\
\hline hodonym & útnév (= hodonima) & Hodonym & hodonyme \\
\hline hydronym & víznév (= hidronima) & $\begin{array}{l}\text { Hydronym } \\
\text { (= Gewässername) }\end{array}$ & hydronyme \\
\hline hypocoristic & becenév & $\begin{array}{l}\text { Hypokoristikon } \\
\text { (= Kosename) }\end{array}$ & hypocoristique \\
\hline inhabitant name & lakossági név & Einwohnername & gentilé \\
\hline last name & vezetéknév & $\begin{array}{l}\text { Familienname } \\
\text { (= Zuname) }\end{array}$ & nom de famille \\
\hline macrotoponym & makrotoponima & Makrotoponym & macrotoponyme \\
\hline metronym & $\begin{array}{l}\text { anyanévi eredetü név } \\
\text { (= matronimikum, } \\
\text { metronimikon) }\end{array}$ & Metronym & matronyme \\
\hline microtoponym & mikrotoponima & $\begin{array}{l}\text { Mikrotoponym } \\
\text { (= Riedname) }\end{array}$ & microtoponyme \\
\hline minor name & mikronév & $\begin{array}{l}\text { Mikrotoponym } \\
\text { (= Riedname) }\end{array}$ & microtoponyme \\
\hline
\end{tabular}




\begin{tabular}{|c|c|c|c|}
\hline name & név & Name & nom \\
\hline name bearer & névviselö & Namenträger & denominatum \\
\hline namegiver & névadó & Namengeber & nommant \\
\hline namegiving & névadás & Namengebung & nomination \\
\hline naming & névadás & Benennung & nomination \\
\hline nesonym & szigetnév & Nesonym & nésonyme \\
\hline nickname & ragadványnév & $\begin{array}{l}\text { Spitzname } \\
\text { (= Neckname) }\end{array}$ & sobriquet \\
\hline odonym & $\begin{array}{l}\text { útnév } \\
\text { (= hodonima) }\end{array}$ & Odonym & odonyme \\
\hline oikonym & településnév & Oikonym & oikonyme \\
\hline onomastician & névkutató & Namenforscher & $\begin{array}{l}\text { onomasticien } \\
\text { (helynevek } \\
\text { vonatkozásában: } \\
\text { toponymiste) }\end{array}$ \\
\hline onomasticon & $\begin{array}{l}\text { névszótár } \\
\text { (= onomasztikon) }\end{array}$ & Onomastikon & onomasticon \\
\hline onomastics & $\begin{array}{l}\text { névtan, névkutatás, } \\
\text { névtudomány } \\
\text { (= onomasztika) }\end{array}$ & Onomastik & onomastique \\
\hline onym & -onima (utótag) & $\begin{array}{l}\text { Onym (melléknévi } \\
\text { formája: onymisch) }\end{array}$ & onyme \\
\hline onymisation & $\begin{array}{l}\text { névvé válás, } \\
\text { tulajdonnévvé válás, } \\
\text { tulajdonnevesülés } \\
\text { (= onimizáció) }\end{array}$ & Onymisierung & onymisation \\
\hline onymy & névállomány & Onymie & onymie \\
\hline oronym & hegynév (= oronima) & Oronym & oronyme \\
\hline patronym & $\begin{array}{l}\text { apanévi eredetü név } \\
\text { (= patronimikum, } \\
\text { patronimikon) }\end{array}$ & Patronym & patronyme \\
\hline personal name & $\begin{array}{l}\text { személynév } \\
\text { (= antroponima) }\end{array}$ & Personenname & nom de personne \\
\hline place name & $\begin{array}{l}\text { helynév } \\
\text { (= toponima) }\end{array}$ & Ortsname & nom de lieu \\
\hline
\end{tabular}


Angol-magyar-német-francia terminusekvivalenciák mutatója...

\begin{tabular}{|c|c|c|c|}
\hline product name & terméknév & Produktname & nom de produit \\
\hline proper name & tulajdonnév & Eigenname & nom propre \\
\hline proprialisation & $\begin{array}{l}\text { névvé válás, } \\
\text { tulajdonnévvé válás, } \\
\text { tulajdonnevesülés } \\
\text { (= onimizáció) }\end{array}$ & Proprialisierung & proprialisation \\
\hline pseudonym & $\begin{array}{l}\text { álnév } \\
\text { (= pszeudonima) }\end{array}$ & Pseudonym & pseudonyme \\
\hline psychoonomastics & pszichoonomasztika & Psychoonomastik & psychoonomastique \\
\hline settlement name & településnév & Siedlungsname & nom d'habitat \\
\hline socioonomastics & szocioonomasztika & Sozioonomastik & socioonomastique \\
\hline street name & utcanév & Straßenname & nom de rue \\
\hline surname & vezetéknév & $\begin{array}{l}\text { Familienname } \\
\text { (= Zuname) }\end{array}$ & nom de famille \\
\hline theonym & $\begin{array}{l}\text { istennév } \\
\text { (= teonima) }\end{array}$ & Theonym & théonyme \\
\hline toponomasticon & $\begin{array}{l}\text { helynévszótár } \\
\text { (= toponomasztikon) }\end{array}$ & Toponomastikon & toponomasticon \\
\hline toponomastics & $\begin{array}{l}\text { helynévkutatás, } \\
\text { helynévtan } \\
\text { (= toponomasztika) }\end{array}$ & Toponomastik & toponymie \\
\hline toponym & helynév (= toponima) & Toponym & toponyme \\
\hline toponymy & helynévállomány & Toponymie & toponymie \\
\hline zoonym & állatnév & Zoonym & zoonyme \\
\hline
\end{tabular}





\section{AZ UNGEGN TERMINUSJEGYZÉKE ÉS MUTATÓJA THE UNGEGN GLOSSARY OF TERMS AND ITS INDEX}

\section{A földrajzi nevek egységesítése során használt terminusok jegyzéke (Magyar változat) \\ $*$ \\ Glossary of Terms for the Standardization of Geographical Names (Hungarian Edition)}

Angol / English Magyar / Hungarian

001 acronym $\quad \begin{aligned} & \text { mozaikszó } \\ & (=\text { akronima })\end{aligned}$

002 address

003 allograph cím

$$
\text { (= akronima) }
$$

allográf (= íráselem-változat, betüváltozat)

\section{Definíció / Definiton}

Egy összetett kifejezés egymást követő tagjainak vagy föbb elemeinek kezdőbetüiből (= betüszó) vagy kezdő betücsoportjaiból (= szóösszevonás) alkotott szó. Példák: UNGEGN (United Nations Group of Experts on Geographical Names); Soweto (South West Townships); radar (RAdio Detection And Ranging).

(a) Az a memóriahely a számítógépben, ahol egy meghatározott információelem tárolódik.

(b) A földrajzi értelemben vett cím lehetővé teszi a tereptárgyak és különösen az emberi lakóhelyek helyhez kötését.

Egy $\rightarrow$ graféma sajátos grafikai megjelenítéseinek egyike. Példák: az angol nyelvben az /f/ $\rightarrow$ fonémát 


\begin{tabular}{|c|c|c|c|}
\hline 004 & allomorph & $\begin{array}{l}\text { allomorf } \\
\text { (= alakváltozat) }\end{array}$ & $\begin{array}{l}\text { Egy adott } \rightarrow \text { morféma két vagy } \\
\text { több különböző } \rightarrow \text { fonológiai meg- } \\
\text { jelenésének egyike. Példa: az angol } \\
\text { nyelvben az -es a „,boxes” szóban, } \\
\text { illetve az -en az „oxen” szóban a } \\
\text { többes számot jelölö morféma } \\
\text { allomorfjai. A magyar nyelvben a } \\
\text { többes szám jelének (a }-K \text { invariáns- } \\
\text { nak) a realizációi (allomorfjai) a } \\
\text { szóalak függvényében: }-k,-a k,-o k \text {, } \\
\text {-ek, -ëk, -ök. }\end{array}$ \\
\hline 005 & allonym & $\begin{array}{l}\text { névváltozat } \\
\text { (= allonima) }\end{array}$ & $\begin{array}{l}\text { Egy adott } \rightarrow \text { topográfiai alakulatra } \\
\text { utaló két vagy több } \rightarrow \text { helynév } \\
\text { (= toponima) egyike. Példák: Hull, } \\
\text { Kingston upon Hull; Vesterhavet, } \\
\text { Nordsee; Swansea, Abertawe; Jo- } \\
\text { hannesburg, Egoli; Szabadka, Su- } \\
\text { botica. }\end{array}$ \\
\hline 006 & $\begin{array}{l}\text { allonym, } \\
\text { standardized }\end{array}$ & $\begin{array}{l}\text { névváltozat } \\
\text { (= allonima), } \\
\text { egységesített } \\
\text { (= standardizált) }\end{array}$ & $\begin{array}{l}\text { Egy adott } \rightarrow \text { topográfiai alakulat } \\
\text { két vagy több } \rightarrow \text { egységesített } \\
(=\text { standardizált) helynevének } \\
\text { egyike. Példák: Biel és Bienne; } \\
\text { Kaapstad és Cape Town; Matter- } \\
\text { horn és Monte Cervino. }\end{array}$ \\
\hline 007 & allophone & $\begin{array}{l}\text { allofón } \\
\text { (= hangváltozat) }\end{array}$ & $\begin{array}{l}\rightarrow \text { Beszédhang, egy } \rightarrow \text { fonéma két } \\
\text { vagy több } \rightarrow \text { fonetikai variációjának } \\
\text { egyike. Példák: a /t/ fonéma egy-egy } \\
\text { allofónja különböztethetö meg a brit } \\
\text { angol Tyne és az amerikai angol } \\
\text { water kifejezésekben; a spanyol } \\
\text { nyelvben az /r/ fonéma két külön- } \\
\text { böző allofónja jelentkezik a río, } \\
\text { illetve a Madrid szavakban; a ma- } \\
\text { gyar nyelvben az /n/ fonéma két } \\
\text { különbözö allofónja van jelen a } \\
\text { nádas és a Harangod szavakban. }\end{array}$ \\
\hline
\end{tabular}

jelölő $\mathrm{f}$ graféma allográfjai az ff, a ph és a gh; a német nyelvben: ss = $\mathrm{sz}=\beta, \ddot{\mathrm{a}}=\mathrm{ae}$; a magyar köznyelvben: $\mathrm{j}=\mathrm{ly}$.

Egy adott $\rightarrow$ morféma két vagy jelenésének egyike. Példa: az angol nyelvben az -es a „boxes” szóban, allomorfjai. A magyar nyelvben a többes szám jelének ( $\mathrm{a}-K$ invariánsa realizácioi (allomorfjai) a szóalak függvényében: $-k,-a k$, $-o k$,

utaló két vagy több $\rightarrow$ helynév (= toponima) egyike. Példák: Hull, Kingston upon Hull; Vesterhavet, hannesburg, Egoli; Szabadka, Su-

két vagy több $\rightarrow$ egységesített (= standardizált) helynevének egyike. Példák: Biel és Bienne; Kaapstad és Cape Town; Matteregyike. Példák: a /t/ fonéma egy-egy allofónja különböztethetö meg a brit water kifejezésekben; a spanyol nyelvben az /r/ fonéma két különböző allofónja jelentkezik a río, illetve a Madrid szavakban; a makülönböző allofónja van jelen a nádas és a Harangod szavakban. 
008 alphabet ábécé

009 alphabetic

alfabetikus

010 alphabet, conversion

ábécé, átírási

011 alphabet, transcription

ábécé, transzkripciós (= kiejtés szerinti átírást szolgáló)

012 alphabet, transliteration ábécé, transzliterációs (= betű szerinti átírást szolgáló)

$\begin{array}{lll}013 & \text { alphabetic script } & \text { betüírás } \\ 014 & \begin{array}{l}\text { alphabetic } \\ \text { sequence }\end{array} & \text { betürend }\end{array}$

Egy $\rightarrow$ betúúrással bíró nyelv $\rightarrow$ betüinek teljes készlete, melyben a betük meghatározott sorrendben, egyenként névvel ellátva szerepelnek.

Az $\rightarrow$ ábécével kapcsolatos, az ábécén alapuló.

A nevek $\rightarrow$ átírásakor alkalmazott $\rightarrow$ ábécé. Összefoglaló kifejezés a $\rightarrow$ transzkripciós (= kiejtés szerinti átírást szolgáló) és a $\rightarrow$ transzliterációs ( $=$ betű szerinti átírást szolgáló) ábécékre.

$\rightarrow$ Ábécé, melyet a $\rightarrow$ transzkripció (= kiejtés szerinti átírás) folyamatában alkalmaznak. Példák: a dentális /ts/ $\rightarrow$ fonéma kizárólag $\mathrm{z}$, nem pedig c betűvel való jelölése németre történő transzkripció során; a veláris $/ \mathrm{k}$ / fonéma kizárólag $\mathrm{k}$, nem pedig c betüvel való jelölése angolra történő transzkripció során.

$\rightarrow$ Ábécé, mely $\rightarrow$ mellékjelet (= diakritikus jelet) is tartalmazhat, $\mathrm{s}$ amelyet a $\rightarrow$ transzliteráció (= betü szerinti átírás) folyamatában alkalmaznak. Példa: ábécék, melyeket a nem latin betüs írások latin betüs átírása során használnak, például a klasszikus arabra vonatkozóan a $\mathrm{C}, \mathrm{E}, \mathrm{O}, \mathrm{P}$, $\mathrm{V}$ és X elhagyásával, de a 'és más kiegészítő írásjegyek megtartásával.

Lásd script, alphabetic (284).

(a) Az a sorrend, melyben egy $\rightarrow$ ábécé $\rightarrow$ betüit szokásosan közlik. (b) Az ilyen sorrendben jegyzékbe foglalt tételek összessége. (Megjegyzés: a magyar szakkifejezés jelentése nem terjed ki a [b]-vel jelölt, az angol terminus által lefedett értelemre.) 


\begin{tabular}{|c|c|c|c|}
\hline 015 & $\begin{array}{l}\text { alphabetic } \\
\text { sequence rules }\end{array}$ & $\begin{array}{l}\text { betürendet } \\
\text { meghatározó szabályok }\end{array}$ & $\begin{array}{l}\mathrm{A} \rightarrow \text { sorrendiséget meghatározó } \\
\text { szabályok } \rightarrow \text { betúírás esetében. }\end{array}$ \\
\hline 016 & alphanumeric & alfanumerikus & $\begin{array}{l}\text { Jelölés, például számítógép eseté- } \\
\text { ben, amely nemcsak számjegyeket, } \\
\text { hanem } \rightarrow \text { betüket is alkalmaz. } \\
\text { Tágabb értelemben írásjelek, ma- } \\
\text { tematikai és egyéb szimbólumok } \\
\text { alkalmazása is. }\end{array}$ \\
\hline 017 & anthroponym & $\begin{array}{l}\text { személynév } \\
\text { (= antroponima) }\end{array}$ & $\begin{array}{l}\text { Személy neve. Példák: Alfred; 'Alī; } \\
\text { Johnson; Kossuth. }\end{array}$ \\
\hline 018 & article & névelő & $\begin{array}{l}\rightarrow \text { Morféma, amely egyértelmüvé } \\
\text { teszi a főnév (általában) határozott } \\
\text { jellegét, néha nyelvtani nemét, } \\
\text { számát és esetét. Példák: angol the; } \\
\text { spanyol el, los, las; francia le, la, } \\
\text { les; magyar a; arab al-; héber ha-; } \\
\text { román -ul. }\end{array}$ \\
\hline 019 & articulation & $\begin{array}{l}\text { artikuláció } \\
\text { (= kiejtés) }\end{array}$ & $\begin{array}{l}\text { Fiziológiai mozdulatok, amelyek a } \\
\text { levegóáramlást módosítják beszéd- } \\
\text { hangok képzése céljából, a gége } \\
\text { feletti beszédszerveket használva. }\end{array}$ \\
\hline A019 & authorized name & engedélyezett név & Lásd name, authorized (A211). \\
\hline 020 & batch processing & $\begin{array}{l}\text { kötegelt } \\
\text { (adat)feldolgozás }\end{array}$ & $\begin{array}{l}\text { Módszer, mely által adatokat kó- } \\
\text { dolnak és gyüjtenek össze csopor- } \\
\text { tokba, hogy aztán a számítógép } \\
\text { egymás után feldolgozza őket, } \\
\text { rendszerint egy későbbi időpont- } \\
\text { ban. Kapcsolódó kifejezés: } \\
\rightarrow \text { interaktív (adat)feldolgozás. }\end{array}$ \\
\hline 021 & bilingualism & $\begin{array}{l}\text { kétnyelvüség } \\
\text { (= bilingvizmus) }\end{array}$ & $\begin{array}{l}\text { Két } \rightarrow \text { nyelv rendszeres használata } \\
\text { például egy személy vagy egy kö- } \\
\text { zösség által. }\end{array}$ \\
\hline 022 & biscriptual & két írásrendszerü & $\begin{array}{l}\text { Két különböző fajta } \rightarrow \text { írásban írott } \\
\text { vagy nyomtatott. Lásd még } \rightarrow \text { több } \\
\text { írásrendszerü térkép; } \rightarrow \text { több } \\
\text { írásrendszerü földrajzinév-tár. }\end{array}$ \\
\hline
\end{tabular}


023 character

írásjegy (= karakter)

024 character, modified

írásjegy

(= karakter), módosított

025 character, simplified

írásjegy (= karakter), egyszerüsített

026 $\begin{array}{ll}\text { character, } & \begin{array}{l}\text { írásjegy- } \\ \text { (= karakter- }) \\ \text { variant } \\ \text { változat }\end{array}\end{array}$

character, vowel írásjegy (= karakter), magánhangzó-jelölö

koronima
Grafikai jel, melyet az írásban egységként használnak; szükebb értelemben egy nem betüírást alkalmazó írásrendszerben használatos grafikai jel. Példák: kínai 中(zhong); japán hiragana $の$ (no).

$\mathrm{Az} \rightarrow$ egyszerúsített írásjegy (= karakter) és az $\rightarrow$ írásjegy(= karakter-)változat összefoglaló megjelölése.

Egy $\rightarrow$ írásjegy (= karakter) változata, mely grafikailag kevésbé összetett, mint az eredeti forma. Példa: a kínai egyszerüsített írásjegyek (Jiantizi) kevesebb vonással, mint a megfelelő hagyományosak.

Egy $\rightarrow$ Írásrendszer két vagy több írásjegye, melyek ugyanazon $\rightarrow$ fonológiai és/vagy $\rightarrow$ morfológiai elemet jelölik (és betüírást alkalmazó írásrendszer esetében, ugyanahhoz a $\rightarrow$ betüképhez tartoznak), de alakjukban különböznek, például a szóban elfoglalt helyük szerint. Példa: héber $\gamma=$ צ.

$\rightarrow$ Betü- vagy $\rightarrow$ szótagírás esetében az az $\rightarrow$ írásjegy (= karakter), nem pedig $\rightarrow$ kiegészítő írásjegy, amely egy $\rightarrow$ magánhangzót jelöl. Példák: Latin a; thai १ (a); koreai † (a).

Egy nagyobb földrajzi terület vagy közigazgatási egység tulajdonneve. Példák: Yorkshire; Ar-Rub a alKhālī; Misiones; Attiki; Alföld. (Megjegyzés: a magyarban a koronima terminus nem ismert, helyette a terminus által jelölt kategória alkategóriáinak a megnevezése vagy körülírás használatos a témától függően; pl. tájnév, megyenév.) 
029 class, feature osztály, alakulat-

030 coded representation

031 colloquial language

A031

commemorative emlékeztető név name composite name

összetett név compound name computer file számítógépes fájl computer program számítógépes program computer record kódolt jelölés társalgási nyelv

osszetett név

számítógépes rekord

mássalhangzó
Hasonló tulajdonságokkal rendelkező topográfiai alakulatok csoportosítása, az osztályozás, keresés és visszakeresés megkönnyítésére. Példa: folyó, patak, csermely, aszó (= csak eső után nedves folyómeder) stb., valamennyi a ,vízfolyás" osztályába sorolva.

Egy objektum vagy egy

$\rightarrow$ alakulatosztály jelölése egy $\rightarrow$ alfanumerikus vagy grafikus kóddal; egy kódolt készlet bármely elemére alkalmazott kód használatának eredménye. Példák: 0226foút; ^ ${ }^{\wedge}$ hegy.

Lásd language, colloquial (146).

Lásd name, commemorative (B211).

Lásd name, composite (212).

Lásd name, composite (212).

Lásd file, computer (098).

Lásd program, computer (268).

Lásd record, computer (275).

A $\rightarrow$ beszédhangok két fő osztályának egyike, amelybe olyan hangok tartoznak, melyek úgy jönnek létre, hogy a tüdőből kiáramló levegő a megfelelő beszédképző szervek által egy vagy több ponton kialakított (zár és/vagy rés típusú) akadályba ütközik. Példák: /b/, /c/, /d/, /f/ hangok. Kapcsolódó kifejezés: $\rightarrow$ magánhangzó. 
038 consonant letter

mássalhangzó-jelölö

betü

039

consonant script mássalhangzó-jelölő

írás

040 conventional név, hagyományos name

conversion

átírás

042

conversion alphabet

conversion table

átírási táblázat

044 coordinates, geographical
Lásd letter, consonant (162).

Lásd script, defective alphabetic (285).

Lásd exonym (081). Az angol kifejezés az $\rightarrow$ exonimára vonatkozó terminus.

Az az eljárás, melynek során egy adott nyelv $\rightarrow$ fonológiai és/vagy $\rightarrow$ morfológiai elemeit egy másik nyelvbe, illetve egyik $\rightarrow$ írásból a másikba viszik át. Az átírás $\rightarrow$ transzkripcióval (= kiejtés szerinti átírással) vagy $\rightarrow$ transzliterációval (= betü szerinti átírással) kivitelezhetö.

Lásd alphabet, conversion (010).

$\mathrm{A} \rightarrow$ transzkripciós (= kiejtés szerinti átírást szolgáló) és $\rightarrow$ transzliterációs (= betű szerinti átírást szolgáló) táblázatokat összefoglaló kifejezés. Lásd még $\rightarrow$ latin betüs átírást szolgáló táblázat.

a) A (szferoid) háló, vagyis az Egyenlítőtől északra és délre $0^{\circ}$-tól $90^{\circ}$-ig számozott szélességi körök, valamint a greenwichi nemzetközi kezdő meridiántól keletre és nyugatra $0^{\circ}$-tól $180^{\circ}$-ig számozott hosszúsági körök hálózata, melyet a Föld felszínén található helyek meghatározására használnak (a magasságra való tekintet nélkül) szögmérés (az ív fokai, percei és másodpercei) segítségével.

(b) Egy pont értéke ezen a hálón. 


045

coordinates, rectangular

koordináták, derékszögü

046 coordinates, topographic

koordináták, topográfiai

047 creole

kreol

adat

050 data base (also database), digital

data base, digital toponymic

adatbázis, digitális (a) Síkkoordináta-hálózat, amely egymással derékszöget bezáró és mindkét tengely mentén egymástól egyenlő távolságra lévő egyenes vonalak két csoportjából áll, mint az eredeti Descartes-féle koordinátarendszer esetében, ilyen az $\rightarrow$ UTM hálózat; vagy amely különböző mértékegységeken alapul, mint némely térképészeti vetület, így például az eredeti Mercator-vetület. (b) Egy pont értéke e hálózat segítségével meghatározva.

Lásd coordinates, rectangular (045).

A beszéd egy állandó változata, amely egy $\rightarrow$ pidzsinből származik, s egy $\rightarrow$ beszélőközösség kizárólagos vagy $\rightarrow$ fö nyelvévé vált. Példa: (a francia alapú) haiti kreol.

Lásd feature, man-made (091).

Tények, fogalmak megjelenítése emberi vagy gépi kommunikáció, értelmezés és feldolgozás számára megfelelően formalizált módon. Kapcsolódó kifejezés a számítástechnikai szóhasználatban:

$\rightarrow$ program, számítógépes.

Egy adott témával kapcsolatos $\rightarrow$ számítógépes fájlok és/vagy $\rightarrow$ számítógépes rekordok átfogó, néha teljes, gyüjteménye. Példa: egy ország valamennyi vízrajzi alakulatára vonatkozó számítógépes rekordok gyüjteménye.

Egy meghatározott terület (valamennyi) $\rightarrow$ helynevét (= toponimáját) - kísérő adatokkal vagy azok 
nélkül - számítógép által olvasható formában tartalmazó $\rightarrow$ digitális adatbázis.

052 data base man- adatbázis-kezelö agement system rendszer

053 data dictionary adatkönyvtár

054 data directory

055 data element

adatkönyvtár

adatelem

056 data field

057 data
interchange,
translingual

058 data item adatmező

adatcsere, nyelvek közötti

adattétel
Egy $\rightarrow$ digitális adatbázis használatához szükséges $\rightarrow$ szoftverek összessége, amely ahhoz kell, hogy az adatbázis önálló felhasználók számára is hozzáférhető legyen.

$\mathrm{A} \rightarrow$ digitális adatbázis-tartalom definícióinak jegyzéke, amely az $\rightarrow$ adatelemek hivatkozási címkéit, $\mathrm{a} \rightarrow$ fájlformátumokat, a belső hivatkozási kódokat és szöveges bejegyzéseket, valamint ezek kapcsolatait tartalmazza.

Lásd data dictionary (053).

Egy $\rightarrow$ számítógépes rekord adott $\rightarrow$ adatmezőjét kitöltő, azonosítható és meghatározható információból felépülő alapegység leírása. Példa: „A név névtestület által való jóváhagyásának dátuma”.

Egy $\rightarrow$ számítógépes rekord meghatározott $\rightarrow$ adateleme számára biztosított hely. Példa: a koordináták számára biztosított mezők egy $\rightarrow$ helynév (= toponima) számítógépes rekordjában.

Szabványosított kódok és/vagy terminológia révén megvalósuló (főként számítógép által kivitelezett) adatcsere, amely nincs egy adott nyelvhez kötve.

Egy adott $\rightarrow$ adatelem értéke vagy tartalma egy meghatározott

$\rightarrow$ számítógépes rekordban. Példa: 01.01.97 a „dátum” $\rightarrow$ adatmezőben. 
059 data portability adathordozhatóság

060 default value

alapértelmezett érték

061

defective hiányos betüírás

alphabetic script

062

descriptive term

leíró kifejezés

063

designation

megjelölés

064

diacritic

mellékjel

(= diakritikus jel)

065 diacritical mark, mellékjel diacritical sign $\quad(=$ diakritikus jel $)$

066 dialect

nyelvváltozat
Azonos adatok különböző számítógépes rendszereken való futtatásának és/vagy használatának lehetősége.

A számítógépes feldolgozás során az a lehetőség, amelyet a számítógép emberi kezelő által bevitt konkrét utasítások hiányában automatikusan választ.

Lásd script, defective alphabetic (286).

Olyan szó (általában köznév, melléknév vagy kifejezés), például térképre nyomtatva, amely a jellemzői alapján jelöl meg egy $\rightarrow$ topográfiai alakulatot, de nem alkot $\rightarrow$ helynevet. Példák: repülőtér; csatorna; víztorony; állandó vagy időszakos (vízfolyás).

Lásd descriptive term (062).

Egy jellemzően kis méretű jel, amelyet egy $\rightarrow$ betü vagy betücsoport fölé, alá vagy a betü(kö)n keresztül helyeznek el, azért, hogy az az eredeti betü( $\mathrm{k}) \rightarrow$ fonemikus értékét megváltoztassa, vagy hogy a hangsúlyt, hanglejtést jelezze, illetve azért, hogy két szót megkülönböztessen. Példák: német ä, ö, ü; magyar á, é; lengyel ł; román ţ; francia où ('hol') az ou ('vagy') ellenében. Lásd még $\rightarrow$ kiegészítő írásjegy.

Lásd diacritic (064).

Egy $\rightarrow$ nyelv területileg vagy társadalmilag elkülönülö változata, amelyet a szavak, nyelvtani szerkezetek egy sajátos készlete és sajátos 
067

dictionary, Szótár, földrajzi geographical

068

069 digital toponymic data base

070 diglossia

071 diglossic

kiejtés jellemez és azonosít. A nyelvváltozat és a $\rightarrow$ nyelv elkülönítése néha nehéz. Lásd még $\rightarrow$ kettősnyelvüség (= diglosszia); $\rightarrow$ vernakuláris (= anyanyelv-) változat.

Rendszerint $\rightarrow$ betürendben megadott földrajzi szakkifejezések és/vagy nevek listája, amely meghatározásokat, magyarázó megjegyzéseket és leíró adatokat tartalmaz az egyes címszavak kapcsán.

Lásd data base, digital (050).

Lásd data base, digital toponymic (051).

Viszonylag stabil nyelvi helyzet, amelyben egy $\rightarrow$ nyelvközösségen belül egy $\rightarrow$ nyelv két különböző változata létezik együtt: az egyik (az ,emelkedett” változat) általában formálisabb és nagyobb presztízsü; a másik (a „köznapi” változat) az informális helyzetekben, főként beszélgetések során használatos. Példák: görög katharevusza (,megtisztított”) és demotikus (,népi”) változatok; a svájci németben: Hochdeutsch és Schwyzerdütsch. Tágabb értelemben két nem rokon nyelv együttes jelenléte, például a spanyol és a guaraní nyelvek Paraguayban.

A $\rightarrow$ kettősnyelvűség (= diglosszia) jelenségével kapcsolatos.

Két egymást követő $\rightarrow$ betü, amely egyetlen $\rightarrow$ fonémát jelöl. Példák: az / / fonéma jelölésére alkalmazott 
073 diphthong

kettőshangzó (= diftongus)

074 donor language

075 donor script

076

endonym

077

endonym, standardized egységesített

078

entity, topographic

079 eponym endonima, (= standardizált)

átadó nyelv

átadó írás

endonima

entitás, topográfiai

eponima sj a holland, ch a francia, sh az angol nyelvben. Néhány nyelvben bizonyos digráfokat az ábécében önállóan sorolnak fel, például: 11 a spanyolban, ch a csehben és a szlovákban, ny a magyarban. Lásd még $\rightarrow$ ligatúra (= ikerbetü).

Két (hármashangzó, azaz triftongus esetében három) magánhangzós elem kapcsolata egyetlen szótagban. Példák: az /a1/ kettőshangzót (= diftongust) jelöli az ei a német „,bei”, az i az angol „time” kifejezésekben.

Lásd language, source (156).

Lásd script, source (293).

Egy $\rightarrow$ földrajzi alakulat neve egy olyan hivatalos vagy széles körben beszélt nyelven, amely azon a területen használatos, ahol maga az alakulat található. Példák: Vārānasī (nem pedig Benares); Aachen (nem pedig Aix-la-Chapelle); Krung Thep (nem pedig Bangkok); Al-Uqşur (nem pedig Luxor); Győr (nem pedig a német Raab); Dunaszerdahely (nem pedig a szlovák Dunajská Streda).

Egy névtestület által jóváhagyott $\rightarrow$ endonima. Példa: a Hull és a Kingston upon Hull (Anglia), a magyar Földvár és Balatonföldvár $\rightarrow$ névváltozatok (= allonimák) közül a második névforma az egységesített (= standardizált) forma.

Lásd topographic feature (334).

Egy személynek vagy személyek egy csoportjának a neve, akiről 
köznevesült helynév

A080

ethnonym

népnév (= etnonima)

081

exonym

exonima vagy amelyröl a hely a nevét kapta. Példák: Iago (Jakab) a Santiago névben; Everest a Mount Everest névben; Mūsa (Mózes) a Wādī Mūsa névben. (Megjegyzés: a magyarban e terminus kevéssé használatos. A franciában az ethnonyme terminus is használatos ebben az értelemben.)

$\rightarrow$ Helynév (= toponima), mely egy köznév alapjául vagy eredetéül szolgál. Példák: Jerez (vö. sherry); Olümpia (vö. olimpia); Cognac (vö. konyak); Canaan (vö. kánaán).

Egy etnikai csoport, például egy törzs vagy klán neve. Példák: dánok, hásimiták, számik, szorbok.

Egy adott nyelvben használt név, mellyel olyan $\rightarrow$ földrajzi alakulatot jelölnek, amely kívül található azon a területen, ahol a kérdéses nyelvet széles körben beszélik, s amely név formájában különbözik a megfelelö $\rightarrow$ endonimá(k)tól, amely(ek)et azon a területen használnak, ahol a földrajzi alakulat található. Példák: az angol Warsaw forma a lengyel Warszawa exonimája; Mailand Milano német neve; Londres London francia neve; Kūlūniyā Köln arab neve; Bécs Wien magyar neve. А Москва angol nyelvre történő latin betüs hivatalos átírásának eredményeként létrejövő Moskva endonima, nem pedig exonima; nem exonima a Beijing pinjin fonetikus ábécé szerinti átírása sem, míg a Peking exonima. Az ENSZ a nemzetközi kommunikációban során az exonimák használatának minimálisra csökkentését javasolja. Lásd még $\rightarrow$ név, hagyományos. 
138 Glossary of Terms for the Standardization of Geographical Names...

\begin{tabular}{|c|c|c|}
\hline $\begin{array}{ll}082 & \begin{array}{l}\text { extraterrestrial } \\
\text { feature }\end{array}\end{array}$ & Földön kívüli alakulat & Lásd feature, extraterrestrial (088). \\
\hline $\begin{array}{l}\text { extraterrestrial } \\
\text { name }\end{array}$ & Földön kívüli név & Lásd name, extraterrestrial (215). \\
\hline $\begin{array}{l}\text { false generic } \\
\text { element }\end{array}$ & $\begin{array}{l}\text { hamis földrajzi } \\
\text { köznévi elem }\end{array}$ & Lásd generic element, false (111). \\
\hline feature class & alakulatosztály & Lásd class, feature (029). \\
\hline feature name & alakulatnév & Lásd toponym (339). \\
\hline feature, cultural & alakulat, mesterséges & Lásd feature, man-made (091). \\
\hline $\begin{array}{l}\text { feature, } \\
\text { extraterrestrial }\end{array}$ & $\begin{array}{l}\text { alakulat, } \\
\text { Földön kívüli }\end{array}$ & $\begin{array}{l}\rightarrow \text { Topográfiai alakulat a Földön } \\
\text { kívül bármely más bolygón, mel- } \\
\text { lékbolygón. Példa: kráter a holdon. }\end{array}$ \\
\hline $\begin{array}{l}\text { feature, } \\
\text { geographical }\end{array}$ & alakulat, földrajzi & $\begin{array}{l}\rightarrow \text { Topográfiai alakulat a Föld } \\
\text { felszínén. }\end{array}$ \\
\hline $\begin{array}{l}\text { feature, } \\
\text { hydrographic }\end{array}$ & alakulat, vízrajzi & $\begin{array}{l}\rightarrow \text { Topográfiai alakulat, amely } \\
\text { vízből áll, vagy főként vízzel hoz- } \\
\text { ható kapcsolatba, de szárazföldet } \\
\text { nem foglal magában. Példák: tó; } \\
\text { föld alatti víztároló; de a sziget nem } \\
\text { vízrajzi alakulat. }\end{array}$ \\
\hline
\end{tabular}

091 feature, $\quad$ alakulat, mesterséges $\rightarrow$ Topográfiai alakulat, amelyet man-made ember hozott létre, vagy lényegesen módosított. Példák: csatorna; közút; lakott hely. Kapcsolódó kifejezés: $\rightarrow$ alakulat, természetes.

092 feature, natural alakulat, természetes

$\rightarrow$ Topográfiai alakulat, amelyet nem ember hozott létre, és lényegesen nem is módosított. Példák: folyó (de a csatorna nem); őserdő (de a telepített erdő nem). Kapcsolódó kifejezés: $\rightarrow$ alakulat, mesterséges.

093 feature, physical alakulat, természeti Bármely vizuálisan észlelhető $\rightarrow$ topográfiai alakulat. Példák: 


\begin{tabular}{|c|c|c|c|}
\hline & & & $\begin{array}{l}\text { hegy; folyó; közút; épület; de pél- } \\
\text { dául a jelzés nélküli politikai hatá- } \\
\text { rok nem tartoznak ide. }\end{array}$ \\
\hline 094 & $\begin{array}{l}\text { feature, } \\
\text { topographic }\end{array}$ & alakulat, topográfiai & $\begin{array}{l}\text { A Föld vagy bármely más bolygó, } \\
\text { illetve mellékbolygó felszínének } \\
\text { felismerhető egyediségú részlete. }\end{array}$ \\
\hline 095 & $\begin{array}{l}\text { feature, } \\
\text { undersea }\end{array}$ & $\begin{array}{l}\text { alakulat, } \\
\text { fenékdomborzati }\end{array}$ & $\begin{array}{l}\text { A Föld óceán vagy tenger felszíne } \\
\text { alatt fekvő részének felismerhető } \\
\text { egyediségü részlete. Példák: Dogger } \\
\text { Bank, Mariana-árok. }\end{array}$ \\
\hline 096 & field, data & mező, adat- & Lásd data field (056). \\
\hline 097 & file format & fájlformátum & Lásd format, file (103). \\
\hline 098 & file, computer & fájl, számítógépes & $\begin{array}{l}\rightarrow \text { Számítógépes rekordok rende- } \\
\text { zett, rendszerezett és névvel ellátott } \\
\text { gyüjteménye. }\end{array}$ \\
\hline 099 & firmware & $\begin{array}{l}\text { firmware (= belső } \\
\text { vezérlőprogram) }\end{array}$ & $\begin{array}{l}\rightarrow \text { Számítógépes programok és } \\
\text { eljárások, amelyeket kártyára vagy } \\
\text { alaplapra rögzítettek, és számító- } \\
\text { gépbe illesztettek vagy beépítettek. } \\
\rightarrow \text { Szoftverparancsokkal nem vál- } \\
\text { toztathatók meg. }\end{array}$ \\
\hline 100 & font & font (= betütípus) & $\begin{array}{l}\text { Adott típusú, stílusú és méretü } \\
\text { betükép. Példa: } 12 \text { pontos fél- } \\
\text { kövér Times New Roman; } \\
11 \text { cpi-s (betű per hü- } \\
\text { velykes) dőlt Courier. }\end{array}$ \\
\hline 101 & format & formátum & $\begin{array}{l}\text { Egy írott vagy nyomtatott dokumen- } \\
\text { tum mérete és általános elrendezése. } \\
\text { Lásd még } \rightarrow \text { formátum, fájl-. }\end{array}$ \\
\hline 102 & $\begin{array}{l}\text { format, } \\
\text { computer }\end{array}$ & $\begin{array}{l}\text { formátum, } \\
\text { számítógépes }\end{array}$ & Lásd format, file (103). \\
\hline 103 & format, file & formátum, fájl- & $\begin{array}{l}\text { Az adatok elrendezése egy } \rightarrow \text { szá- } \\
\text { mítógépes fájlban (pl. rekordok és }\end{array}$ \\
\hline
\end{tabular}


104 full title 105 gazetteer

107

gazetteer, multilingual

gazetteer, multiscriptual

gazetteer, place names földrajzinév-mutató

teljes megnevezés

földrajzinév-tár

földrajzinév-tár, többnyelvü

földrajzinév-tár, több írásrendszerű

névtár, helység-

földrajzi köznévi elem mezők, numerikus és $\rightarrow$ alfanumerikus, rögzített és lebegőpontos stb.). Általában egyszerüen csak formátumként utalnak rá

Lásd long form (of a name) (183).

$\rightarrow$ Földrajzi nevek betürendben vagy egyéb sorrendben elrendezett listája, az elhelyezkedés jelzésével, és lehetőség szerint a névváltozatok, a $\rightarrow$ topográfiai alakulat típusa és más meghatározó vagy leíró információk feltüntetésével.

$\rightarrow$ Földrajzi nevek rendezett listája kiegészítő adatokkal vagy azok nélkül, mely mutatóul szolgál ahhoz a forráshoz, amelyben a nevek találhatóak. Példa: atlaszhoz mellékelt földrajzinév-mutató.

$\rightarrow$ Földrajzinév-tár, amely, egy adott topográfiai alakulat kapcsán, különböző nyelvü, nem feltétlenül $\rightarrow$ egységesített (= standardizált) névváltozatokat (= allonimákat) közöl. Példák: Athens (Athína); Moscou (Moskva).

$\rightarrow$ Földrajzinév-tár, amely a $\rightarrow$ földrajzi neveket két (két írásrendszerü) vagy több különböző típusú $\rightarrow$ írásban vagy $\rightarrow$ írásrendszer-

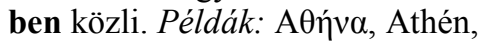
נצרת, Názáret; Владивосток, Vlagyivosztok.

Az angol terminust időnként lakott helyek neveinek listájára alkalmazzák. Lásd még $\rightarrow$ név, hely- (b).

$A \rightarrow$ földrajzi név $\rightarrow$ földrajzi köznévi része. Példák: Port-auPrince; Sierra Nevada; Newport; Gellért-hegy. A földrajzi köznévi 
111 generic element, földrajzi köznévi false elem, hamis

112 generic term

földrajzi köznév

113 geographical dictionary

114 geographical entity

115 geographical feature

116 geographical name

117 geographical names standardization

földrajzinévegységesítés

B118 geonym elem nem feltétlenül a megnevezett objektum alakulattípusát vagy alakulatosztályát mutatja meg. Lásd még $\rightarrow$ hamis földrajzi köznévi elem. Kapcsolódó kifejezés: $\rightarrow$ megkülönböztető elem.

$\rightarrow$ Földrajzi köznévi elem, amely nem a megnevezett objektum alakulatosztályát mutatja. Példák: a Mount Isa, 'Ayn as-Sulţān, Redhill,

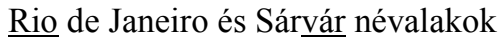
településeket, nem pedig hegyet, forrást, dombot, folyót, illetve várat jelölnek, ahogy azt a nevek jelzik.

Köznév, amely a $\rightarrow$ topográfiai alakulatot tulajdonságai, nem pedig neve révén azonosítja. Példák: mountain, sierra, san, shan, dagh, jabal, har, river, wadi, gang, patak, domb. A $\rightarrow$ helynév (= toponima) részét képezheti; lásd $\rightarrow$ földrajzi köznévi elem. Lásd még $\rightarrow$ földrajzi köznévi elem, hamis.

Lásd dictionary, geographical (067).

Lásd feature, geographical (089).

Lásd feature, geographical (089).

Lásd name, geographical (216).

Lásd standardization, geographical names (312).

Lásd name, geographical (216). A magyarban ritkán használatos. 


$118 \begin{array}{ll}\text { geographic } & \text { geoinformációs } \\ \text { information } & \text { rendszer (GIS) } \\ \text { system (GIS) } & \end{array}$

A118

geoname

geonima

119 GIS

120 glossary

121

grammar

122

grapheme

123 graphic form

124 graticule

125 grid, topographic nyelvtan

graféma

grafikai forma

GIS

szójegyzék

fokhálózat

hálózat, topográfiai (= térképhálózat)
Számítógépen futó sokfunkciós rendszer, amely - gyakran térképeket és $\rightarrow$ helyneveket is tartalmazó - georeferált $\rightarrow$ adatok bevitelét, feldolgozását és kinyerését teszi lehetővé.

Lásd name, geographical (216). Az angol terminus $\mathrm{a} \rightarrow$ földrajzi névre használt informális kifejezés.

Lásd geographic information system (118).

Egy meghatározott tudományterületre vagy tárgykörre vonatkozó szakkifejezések jegyzéke, amely a felsorolt kifejezések kapcsán magyarázó vagy leíró tájékoztatást is nyújthat. Példa: a földrajzi nevek egységesítése kapcsán használatos szakkifejezések jegyzéke.

Egy $\rightarrow$ nyelv alaki jegyeivel és az ezek összekapcsolását, vonatkozásait és értelmezését meghatározó szabályokkal foglalkozó tudományterület.

Egy $\rightarrow$ fonéma grafikai megjelenítése egy adott $\rightarrow$ nyelvben. Példák: a $\mathrm{j} \rightarrow$ graféma az angolban a /ds/, a franciában a $/ 3 / \rightarrow$ fonéma jelölője.

Írott vagy nyomtatott, $\rightarrow$ mellékjelet (= diakritikus jelet) is tartalmazó $\rightarrow$ írásjegy(ek) (= karakter[ek]), amely(ek) egy nyelvi egységet (például egy nevet) jelöl(nek). Különbözik a beszélt és digitális formáktól.

Lásd coordinates, geographical (a) (044).

Lásd coordinates, rectangular (a) (045). 
126 guidelines, toponymic

irányelvek, helynév-egységesítési

127 hardware

hardver

128

129 hodonym

historical name

történeti név

útnév

(= hodonima)

130 homonym

homonima

131 hydrographic feature

132

hydronym

víznév

(= hidronima)

133 hyphenization, kötőjelezés also hyphenation
Egy ország $\rightarrow$ helyneveinek (= toponimáinak) $\rightarrow$ egységesítését (= standardizációját) és az egységesített helynevek térképeken és $\rightarrow$ helynévtárakban való közreadását meghatározó szabályok készlete.

Maga a számítógép (központi feldolgozó egység, az ún. CPU), továbbá valamennyi külső bemeneti és kimeneti eszköz (például monitorok, mágneslemezes tárolók, [hang]rögzítő konzolok, nyomtatók, térképkészítők, digitalizálók, szkennerek stb.). Kapcsolódó kifejezés: $\rightarrow$ szoftver.

Lásd name, historical (217).

Lásd odonym (247). A hodonima terminus a magyarban ritkán használatos.

Két vagy több azonos $\rightarrow$ helynév (= toponima), amelyek különböző $\rightarrow$ topográfiai alakulatokat jelölnek. Példa: Monaco (Principauté de) és Monaco (di Baviera), utóbbi olasz nyelvü $\rightarrow$ exonima, mely Münchent jelöli. Példa a magyar nyelvből: Sárospatak (magyarországi város) és Sárospatak (erdélyi falu); Medina (város Szaúd-Arábiában) és Medina (falu Tolna megyében).

Lásd feature, hydrographic (090).

Egy $\rightarrow$ vízrajzi alakulatra alkalmazott $\rightarrow$ helynév (= toponima).

a) A helynévtanban egy

$\rightarrow$ összetett név két vagy több 
134 ideogram

ideogramma

(= képírásjel)

elemének kötőjellel való összekapcsolása; ez rendszerint megakadályozza a szavak sorrendjének megváltozását az olyan $\rightarrow$ betürendes jegyzékben, mint amilyen a $\rightarrow$ földrajzinév-tár. Példák: HöhrGrenzhausen; Tel-Aviv; PointeSapin-Centre.

(b) Kötőjelek elhelyezése szavak, illetve egy szó szótagjai közé.

(a) Grafikai jel, amely egy dolgot vagy egy fogalmat ábrázol, de nem feltétlenül egy ezekre használatos adott szót jelöl. Néhány szerző a $\rightarrow$ logogramra (= szójelre) használja.

(b) Az egyiptomi hieroglifák esetében olyan determináns, amely $\rightarrow$ fonogrammák (= hangjelek) (csoportjának a) jelentését jelzi.

135 ideographic script

136 index, names

137 index, place names

138 index, toponymic

139 indigenous language

140 indigenous name ideogrammatikus írás (= fogalomírás, képírás)

mutató, név-

mutató, helynév-

mutató, helynév-

öshonos nyelv

őshonos név
Lásd script, logographic (289).

Lásd index, toponymic (138).

Lásd index, toponymic (138). Az angol terminust néha csak lakott helyekkel összefüggésben alkalmazzák. Lásd még $\rightarrow$ helynév (= toponima).

$\rightarrow$ Helynevek (= toponimák) rendezett listája, amely a földrajzi elhelyezkedésen kívül kevés egyéb információt közöl, illetve semmilyen további adatot nem tartalmaz.

Lásd language, indigenous (148).

Lásd name, indigenous (218). 


$141 \begin{array}{ll}\text { interactive } & \text { interaktív } \\ \text { processing } & \text { (adat)feldolgozás }\end{array}$

142 interface

interfész

143 International Phonetic Alphabet, IPA

nemzetközi fonetikai ábécé, IPA (= APhI)

144 international standardization

nemzetközi

egységesítés (= standardizáció)

A144 lacustrine name

tónév

145 language

nyelv

146 language, colloquial
Számítógépes rendszerben egy programmal és/vagy adatokkal való közvetlen munkafolyamat, melynek célja az információk azonnali módosítása, kinyerése és/vagy megjelenítése. Ez rendszerint számítógép képernyőjén történik. Kapcsolódó kifejezés: $\rightarrow$ kötegelt (adat)feldolgozás.

Közös határ, amelyen két különböző számítógépes rendszer vagy ezek részei összekapcsolódnak vagy keresztezik egymást. Ez lehet mechanikus vagy elektronikus, és vonatkozhat az ember és a számítógép közötti kapcsolatra is.

$\rightarrow$ Fonetikai átírásra szolgáló, nemzetközileg elismert jelek készlete. Néhány példa IPA jelölésre: [y] az angol ,sing” szó ,ng” hangjára; [ ] ] az angol ,sh" hangra; [a] az „,art” szó ,a”-jára, de [ $\varepsilon]$ az ,any” szó „a"-jára; [u] a mássalhangzós „u”-ra a francia „Suisse” szóban.

Lásd standardization, international, geographical names (313).

Lásd name, lacustrine (A218).

E szójegyzék összefüggésrendszerében a szóbeli kommunikáció egy nagyobb közösség által használt eszköze, amely magában foglalja a szavakat, azok kiejtését és összekapcsolásuk módozatait.

A $\rightarrow$ nyelv azon formája, amely az informális $\rightarrow$ beszédben használatos, s amely észrevehetően különbözik a formális társalgás és írás 


\begin{tabular}{|c|c|c|}
\hline 147 & language, donor & nyelv, átadó \\
\hline 148 & $\begin{array}{l}\text { language, } \\
\text { indigenous }\end{array}$ & nyelv, öshonos \\
\hline 149 & $\begin{array}{l}\text { language, } \\
\text { literary }\end{array}$ & nyelv, irodalmi \\
\hline
\end{tabular}

150 language, minority

151 language, national

152 language, non-official or unofficial során használt változattól. Lásd még $\rightarrow$ nyelvváltozat; $\rightarrow$ kettősnyelvüség (= diglosszia).

Lásd language, source (156).

$\rightarrow$ Nyelv, amely őshonos egy adott területen.

$\mathrm{A} \rightarrow$ nyelv, különösen a köznyelv írott formája, amelyet egyes, föként korábbi vélekedések irodalmi müvek esetében a kívánatos mintának tartottak. A formális nyelvhasználat alapját is képezheti. Lásd még $\rightarrow$ kettősnyelvüség (= diglosszia).

Egy adott területen az állami adminisztráció $\rightarrow$ hivatalos nyelvétől különböző $\rightarrow$ nyelv, amelyet egy kisebbség beszél. Hivatalos jogállással rendelkezik vagy nem rendelkezik. Példák: a svéd nyelv Finnországban, a breton nyelv Franciaországban, a fríz nyelv Hollandiában.

Egy adott ország egészében vagy területének részein jelenleg is széles körben elterjedten használt $\rightarrow$ nyelv, amely gyakran beszélőinek identitását jelképezi. A $\rightarrow$ hivatalos nyelv jogállásával rendelkezik vagy nem rendelkezik. Példa: a rétoromán (Rätoromanisch) nyelv Svájc egyes vidékein.

nyelv, nem hivatalos

Egy $\rightarrow$ nyelv, amely, bár viszonylag széles körben használatos, egy adott, törvény által létrehozott politikai egységben hivatalosan megerősített jogállással nem bír. Példa: a francia nyelv Libanonban, az angol nyelv Izraelben. 
153 language, nyelv, hivatalos official

154 language, principal

155 language, receiver

156 language, source

language, nyelv, közstandard
Egy $\rightarrow$ nyelv, melynek törvényben rögzített hivatalos jogállása van egy adott, törvény által létrehozott politikai egységben, például egy államban vagy annak egy részében, és amely az adminisztráció nyelveként szolgál. Példák: a spanyol nyelv Chilében, az olasz és a német nyelv Dél-Tirolban (Olaszország).

A több $\rightarrow$ nyelvet használó $\rightarrow$ nyelvközösségekben a legtöbb beszélővel rendelkező nyelv. Példa: a német, nem pedig az olasz nyelv Dél-Tirolban (Olaszország); az angol, nem pedig a walesi nyelv Walesben.

Lásd language, target (158).

Az a $\rightarrow$ nyelv, amelyböl egy nevet átalakít, vagy átvesz egy másik nyelv, a $\rightarrow$ célnyelv. Példa: oroszról kínaira történő $\rightarrow$ átírás esetén az előbbi a forrásnyelv.

Egy nyelv azon beszélt és/vagy írott formája, amelyet egy hivatalosan kijelölt vagy széles körben elismert testület vagy szaktekintély helyesnek minősít, illetve, ezek hiányában, az a forma, amelyet általánosságban helyesnek fogad el a $\rightarrow$ nyelvközösség. Példák: a Hochdeutsch a német esetében; az Algemeen Beschaafd Nederlands Hollandiában.

Az a nyelv, amelynek szabályai szerint egy $\rightarrow$ helynév (= toponima) a $\rightarrow$ forrásnyelvből átvehető vagy átalakítható. Példa: arabról franciára történő $\rightarrow$ átírás esetén az utóbbi a célnyelv. 
159 language, nyelv, közvetítö vehicular

160 letter

betü

161 letter, basic

betü, alap-

162

letter, consonant

betü,

mássalhangzó-jelölö

163 letter, vowel

164 lettering, map

165 lettering, multilingual

166 lettering, multiscriptual

167 letters, cardinal névírás, térképi

írás,

több írásrendszerü

betü, magánhangzó-jelölő

írás, többnyelvü betük, alap-
Az a nyelv, amely kommunikációs eszközként szolgál különböző $\rightarrow$ nyelvközösségek tagjai között. Példa: az angol nyelv a polgári légi közlekedés közvetítő nyelve a világ nagy részén.

Grafikai jel, amely egységként vagy $\rightarrow$ írásjegyként (= karakterként) szolgál egy $\rightarrow$ ábécében.

Egy $\rightarrow$ betü alapformája $\rightarrow$ mellékjelek (= diakritikus jelek) nélkül. Példák: lengyel 1 az ł ellenében; izlandi $\mathrm{D}$ a $Đ$ ellenében.

Egy $\rightarrow$ ábécé mássalhangzót jelölö

$\rightarrow$ betüje. Példák: latin b, d; görög $\beta$, $\delta$; thai ข, ด; arab ب, د; koreai 廿,

Egy $\rightarrow$ ábécé magánhangzót jelölő $\rightarrow$ betüje. Példák: latin a, e, i, o, u; görög $\alpha, \varepsilon, \eta, 1, o, v, \omega$; orosz a, e, и, о, y; héber i; thai ı; koreai $\perp, \top$.

(a) $\rightarrow$ Térképi írás egy $\rightarrow$ betüírást alkalmazó írásrendszerben. Tágabb értelemben $\rightarrow$ térképi írás.

(b) ( $\rightarrow$ Alfabetikus) írás térképre való illesztésének tevékenysége. Ebben a jelentésben a magyar terminus nem használatos.

$\rightarrow$ Térképi névírás egy $\rightarrow$ többnyelvü térképen.

$\rightarrow$ Térképi névírás egy $\rightarrow$ több írásrendszerü térképen.

Egy $\rightarrow$ írás azon $\rightarrow$ betűi, amelyeket az adott írást használó legtöbb $\rightarrow$ ábécé tartalmaz. Példák: a latin ábécé kivéve például a $\mathrm{K}, \mathrm{Q}, \mathrm{X}$ betűket; a perzsa (farszi) ábécé 


\begin{tabular}{|c|c|c|c|}
\hline & & & $\begin{array}{l}\text { hagyományos arab betüi. Kapcsolódó } \\
\text { kifejezés: } \rightarrow \text { betük, különleges. }\end{array}$ \\
\hline 168 & letters, special & betük, különleges & $\begin{array}{l}\text { Egy adott nyelv } \rightarrow \text { ábécéjének } \\
\text { azok a } \rightarrow \text { betűi, melyek jellemzőek, } \\
\text { illetve egyedülállóak a kérdéses } \\
\text { nyelvben, mivel hiányoznak vala- } \\
\text { mennyi vagy a legtöbb más ábécé- } \\
\text { ből, amely ugyanazt az írást hasz- } \\
\text { nálja. Példák: dán ø; izlandi b, ð; } \\
\text { német } \beta \text {; perzsa گં; magyar ü. Kap- } \\
\text { csolódó kifejezés: } \rightarrow \text { betűk, alap-. }\end{array}$ \\
\hline 169 & lexicon & lexikon & $\begin{array}{l}\text { (a) Egy adott nyelvre vagy ismeret- } \\
\text { körre vonatkozó szótár vagy } \\
\rightarrow \text { szójegyzék. } \\
\text { (b) Egy egyén, foglalkozási csoport } \\
\text { vagy szakterület szókincse. }\end{array}$ \\
\hline 170 & $\begin{array}{l}\text { lexicon, } \\
\text { logographic }\end{array}$ & készlet, szójel- & $\begin{array}{l}\text { Egy } \rightarrow \text { szójelölő írás } \\
\rightarrow \text { írásjegyeinek (= karaktereinek) } \\
\text { rendezett listája; a } \rightarrow \text { betüírásban } \\
\text { az } \rightarrow \text { ábécé, a } \rightarrow \text { szótagírásban a } \\
\rightarrow \text { szótagjelkészlet a megfelelője. }\end{array}$ \\
\hline 171 & ligature & $\begin{array}{l}\text { ligatúra } \\
\text { (= ikerbetü) }\end{array}$ & $\begin{array}{l}\text { Két } \rightarrow \text { betü grafikailag stilizált } \\
\text { kombinációja, illetve egy összekötő } \\
\text { vonal vagy vonás, amely azt jelzi, } \\
\text { hogy az egymásra következő han- } \\
\text { gokat egyként kell ejteni. Példák: } \\
\text { œ (amely az } o+e \text { kapcsolatból } \\
\text { származik); kh, amelyet az } \rightarrow \text { IPA } \\
\text { /x/-nak, illetve a német } a c h \text { szóban } \\
\text { található ch-nak megfelelöen ejtünk. }\end{array}$ \\
\hline 172 & lingua franca & lingua franca & $\begin{array}{l}\text { Segédnyelv, amelyet különböző anya- } \\
\text { nyelvü embercsoportok közti kom- } \\
\text { munikációra használnak. Példák: a } \\
\text { szuahéli Kelet-Afrikában, a kecsua az } \\
\text { Andok vidékén. Lásd még } \rightarrow \text { pidzsin. }\end{array}$ \\
\hline 173 & linguistic area & nyelvterület & Lásd linguistic region (175). \\
\hline
\end{tabular}


174 linguistic nyelvközösség community

175 linguistic region nyelvi régió

176 linguistics nyelvészet

177 literary language

178 local name

179 logogram

logogram logogram

(= szójel)

180

logographic Szójelölő

181 logographic lexicon

182 logographic script

183 long form (of a name)
Egyének egy csoportja, amely viszonylag könnyen kommunikál egy közös $\rightarrow$ nyelven vagy $\rightarrow$ nyelvváltozatban.

Régió vagy terület, ahol egy adott nyelv alkotja a $\rightarrow$ hivatalos vagy $\rightarrow$ fö nyelvet. Példa: a flamand és vallon nyelvi régiók Belgiumban.

Az emberi nyelv tudományos, minden szempontra kiterjedő vizsgálata, amely magában foglalja a $\rightarrow$ fonetikát (= hangtant), $\mathrm{a} \rightarrow$ fonológiát, $\mathrm{a} \rightarrow$ morfológiát (= alaktant), $\mathrm{a} \rightarrow$ szintaxist (= mondattant) és a $\rightarrow$ szemantikát (= jelentéstant).

Lásd language, literary (149).

Lásd name, local (219).

Grafikai jel vagy jelek kombinációja, amely egy teljes szabad $\rightarrow$ morfémát, például egy szót, jelöl, anélkül, hogy az azt alkotó $\rightarrow$ fonémákat vagy $\rightarrow$ szótagokat elkülönítve feltüntetné. Példák: a kínai 中 a zhong (közép) szóra; a japán kandzsi 山 a san vagy yama (hegy) szavakra.

$\rightarrow$ Logogramokból (= szójelekből) álló, illetve azokkal kapcsolatos.

Lásd lexicon, logographic (170).

Lásd script, logographic (289).

Egy $\rightarrow$ helynévnek (= toponimának) (különösen egy ország nevének) 


\begin{tabular}{|c|c|c|c|}
\hline & & & $\begin{array}{l}\text { teljes, minden alkotóelemet magában } \\
\text { foglaló formája. Példák: Al- } \\
\text { Mamlakah al-Hāshimīyah al- } \\
\text { Urdunīyah (Jordán Hásimita Király- } \\
\text { ság); Zhonghua Renmin Gongheguo } \\
\text { (Kínai Népköztársaság). Kapcsolódó } \\
\text { kifejezés: } \rightarrow \text { rövid névforma; a } \\
\text { fenti példák esetében: Al-Urdun } \\
\text { (Jordánia); Zhongguo (Kína). }\end{array}$ \\
\hline 184 & lunar name & holdfelszíni név & Lásd name, lunar (220). \\
\hline 185 & $\begin{array}{l}\text { man-made } \\
\text { feature }\end{array}$ & mesterséges alakulat & Lásd feature, man-made (091). \\
\hline 186 & map lettering & térképi névírás & Lásd lettering, map (164). \\
\hline 187 & $\begin{array}{l}\text { map, } \\
\text { multilingual }\end{array}$ & térkép, többnyelvü & $\begin{array}{l}\text { Térkép, amely egy adott topográfiai } \\
\text { alakulat kapcsán különböző } \\
\rightarrow \text { nyelveken, nem feltétlenül } \\
\rightarrow \text { egységesített (= standardizált), } \\
\text { névváltozatokat (= allonimákat) } \\
\text { közöl. Példák: Athens, Athína, } \\
\text { Athén; Moscou, Moskva, Moszkva. }\end{array}$ \\
\hline 188 & $\begin{array}{l}\text { map, } \\
\text { multiscriptual }\end{array}$ & $\begin{array}{l}\text { térkép, } \\
\text { több írásrendszerü }\end{array}$ & $\begin{array}{l}\text { Térkép, amely a } \rightarrow \text { helyneveket két } \\
\text { (két írásrendszerü) vagy több kü- } \\
\text { lönböző típusú } \rightarrow \text { írásban vagy } \\
\rightarrow \text { írásrendszerben közli. Példák: } \\
\text { AӨฑ́va, Athén; נצרת, Názáret; } \\
\text { Владивосток, Vlagyivosztok. }\end{array}$ \\
\hline 189 & map script & térképi írás & $\begin{array}{l}\rightarrow \text { Helynevek és egyéb nyelvi vagy } \\
\text { numerikus adatok - mint például } \\
\text { leíró kifejezések, pontszerü és } \\
\text { körvonalazható kiemelkedések - a } \\
\text { térképen. Lásd még } \rightarrow \text { névírás, } \\
\text { térképi. }\end{array}$ \\
\hline 190 & $\begin{array}{l}\text { map script, } \\
\text { multilingual }\end{array}$ & $\begin{array}{l}\text { térképi írás, } \\
\text { többnyelvü }\end{array}$ & $\begin{array}{l}\rightarrow \text { Térképi írás egy } \rightarrow \text { többnyelvü } \\
\text { térképen. }\end{array}$ \\
\hline 191 & $\begin{array}{l}\text { map script, } \\
\text { multiscriptual }\end{array}$ & $\begin{array}{l}\text { térképi írás, több } \\
\text { írásrendszerü }\end{array}$ & $\begin{array}{l}\rightarrow \text { Térképi írás egy } \rightarrow \text { több írás- } \\
\text { rendszerü térképen. }\end{array}$ \\
\hline
\end{tabular}


192 map, thematic térkép, tematikus

193 map, topographic

térkép, topográfiai

maritime name

tengeri név

195 marker

kiegészítő írásjegy

196 marker, vowel

198 minority language minority name menü, számítógépes

kiegészítő írásjegy, magánhangzó-jelölő

kisebbségi nyelv

kisebbségi név

módosított írásjegy (= karakter) modified character
Bármely, sajátos témának szentelt földrajzi térkép, amely nem csak a Föld felszíni terepalakulatait mutatja. Példák: geológiai térkép, történeti térkép, légi útvonalak térképe. Kapcsolódó kifejezés:

$\rightarrow$ topográfiai térkép.

Olyan térkép, melynek célja a Föld vagy a Hold, illetve egy bolygó vagy mellékbolygói felszínének, valamint $\rightarrow$ természetes és $\rightarrow$ mesterséges $\rightarrow$ topográfiai alakulatainak ábrázolása. Kapcsolódó kifejezés: $\rightarrow$ térkép, tematikus.

Lásd name, maritime (221).

$\rightarrow$ Fonémát, $\rightarrow$ morfémát vagy a nyelv más elemét jelölö grafikai jel, amelyet csak egy önálló $\rightarrow$ betúvel vagy $\rightarrow$ szillabogrammal (= szótagjellel) összekapcsolva használnak. Példa: az arab shaddah (megkettőzést jelölő kiegészítő írásjegy).

$\rightarrow$ Hiányos betüírásban alkalmazott $\rightarrow$ kiegészítő írásjegy $\rightarrow$ magánhangzó jelölésére. Példák: arab , , (a, i, u); héber , , , , (a, e, i, o, u); thai , , (a, i, u).

A számítógép kezelője számára hozzáférhető, általában grafikus vagy $\rightarrow$ alfanumerikus formában a számítógép képernyőjén feltüntetett lehetőségek listája.

Lásd language, minority (150).

Lásd name, minority (222).

Lásd character, modified (024). 
201 morpheme morféma morphological morfológiai morphology

morfológia (= alaktan)

204 mother tongue

anyanyelv

205 multilingual gazetteer

többnyelvü földrajzinév-tár

206 multilingual map

207 multiscriptual gazetteer

208 multiscriptual map

name

name alternative

B211 name, commemorative

több irásrendszer térkép

név

név, alternatív
A legkisebb megkülönböztető egység a $\rightarrow$ nyelvtanban; a szó funkcióval bíró összetevőinek legkisebb egysége. Példa: a „dülők” szó a „dülő" szabad és a többes számot jelölö ,--k” kötött morfémákból áll.

$\mathrm{A} \rightarrow$ morfológiával (= alaktannal) kapcsolatos.

$\mathrm{A} \rightarrow$ nyelvtan azon ága, amely egy nyelv szavainak a szerkezetét és alakját tanulmányozza.

A családon belül elsajátított első nyelv.

Lásd gazetteer, multilingual (107).

Lásd map, multilingual (187).

Lásd gazetteer, multiscriptual (108).

több írásrendszerü

Lásd map, multiscriptual (188).

(a) Lásd noun, proper (246).

(b) E szójegyzék sajátos összefüggésrendszerében: $\rightarrow$ helynév (= toponima).

Lásd allonym (005).

név, emlékeztető

Egy személyről vagy egy eseményről elnevezett természetes vagy mesterséges $\rightarrow$ földrajzi alakulat neve, amelyet azzal a céllal alkottak meg, hogy a névadó személy vagy esemény iránt tiszteletet tanúsítsanak, róla megemlékezzenek. Példák: Isla de Pascua (Húsvétsziget, Chile); Sydney (Ausztrália); Blyderivier (Dél-Afrika). 
211 name, approved név, jóváhagyott

A211 name, authorized

212 name, composite

név, összetett

név, engedélyezett

Lásd name, standardized (228).

Lásd name, official (223).

$\rightarrow$ Helynév (= toponima), amely egy $\rightarrow$ földrajzi köznévi elemből és egy $\rightarrow$ megkülönböztető elemből, vagy egy több szóból álló megkülönböztető elemből épül fel. Példák: Mount Cook; Newport; Newfoundland; Kemijoki; Rostov na Donu; Sierra Nevada Oriental; Stoke on Trent. Kapcsolódó kifejezés: $\rightarrow$ név, egyszerü.

213 name compound

214 name, conventional

215 name, extraterrestrial

216 name, geographical

218 name, indigenous név, földrajzi

név, történeti

név, összetett

név, hagyományos

név, Földön kívüli (1)

név, őshonos
Lásd name, composite (212).

Lásd exonym (081).

$\rightarrow$ Földön kívüli alakulatra alkalmazott $\rightarrow$ helynév (= toponima). Példa: Nix Olympica (a Marson).

Egy Földön található alakulatra alkalmazott $\rightarrow$ név; a $\rightarrow$ topográfiai név vagy $\rightarrow$ helynév (= toponima) sajátos esete.

Történeti feljegyzés(ek)ben található $\rightarrow$ helynév (= toponima), amely jelenleg már nincs használatban. Példák: Eboracum (az angliai York jelölésére); Mediolanum (az olaszországi Milanó jelölésére); New Amsterdam (az egyesült államokbeli New York jelölésére); Edo (a japán Tokió jelölésére); Alba Regia (a magyarországi Székesfehérvár jelölésére).

Egy $\rightarrow$ őshonos nyelvü vagy abból származó $\rightarrow$ helynév (= toponima). Példák: Culabah (őshonos, Ausztrália), Empangeni (zulu, Dél-Afrika). 
A218 name, lacustrine név, tó-

219 name, local név, helyi

220 name, lunar név, holdfelszíni

221 name, maritime név, tengeri

222 name, minority név, kisebbségi

223 name, official név, hivatalos

224 name, place név, hely-

225 name, primary név, elsődleges

226 name, proper név, tulajdon-

227 name, simplex név, egyszerü
Egy tó vagy belső tenger neve. Példák: Holt-tenger; Balkas-tó (v. Balhas-tó); Malawi (Nyasza)-tó.

A $\rightarrow$ nyelvközösség egy földrajzilag meghatározott területen élő köre által egy ott található alakulatra alkalmazott $\rightarrow$ helynév (= toponima). Különbözhet az $\rightarrow$ egységesített (= standardizált) névtől.

A Hold felszínén található alakulatra alkalmazott $\rightarrow$ helynév (= toponima) Példák: Gagarin holdkráter; Nyugalom tengere (Mare Tranquillitatis).

Egy, a tengerrel kapcsolatos $\rightarrow$ vízrajzi alakulat neve. Példák: Magellán-szoros, Bottenhavet/ Selkämeri, La Manche csatorna.

(Hely)név $\rightarrow$ kisebbségi nyelven.

Egy jogilag felállított (pl. nemzeti) $\rightarrow$ névtestület által jóváhagyott, annak hatáskörében alkalmazott $\rightarrow$ helynév (= toponima).

(a) Lásd toponym (339).

(b) Néhány szakíró a helységnév $\rightarrow$ szinonimájaként használja.

Helyi kifejezésekkel és nyelven megalkotott leíró név. Példák: ArRub' al-Khālī (az üres negyed, Szaúd-Arábia); Dasht-e Kavīr (nagy sivatag, Irán).

Lásd noun, proper (246).

Egy szóból, általában pusztán egy megkülönböztető összetevőből álló $\rightarrow$ helynév (= toponima).

Példák: Kijev; Temuko; Malawii. Az al-Qāhirah (Kairó) szintén egyszerü név, mivel az arab eredetiben 
A227 name, standard

228 name, standardized név, egységesített (= standard)

név, egységesített (= standardizált)

229 name, topographic

230 name, traditional

name, transboundary name, variant

név, határt átívelő

név-, változat (= allonima)

név, topográfiai

név, hagyományos

névtestület az al- névelő kötött $\rightarrow$ morféma, azaz az egységhez tartozó, kötőjel nélkül írt prefixum (= elötag). Kapcsolódó kifejezés: $\rightarrow$ név, összetett.

Lásd name, standardized (228).

Egy $\rightarrow$ névtestület által egy adott alakulatra alkalmazott számos $\rightarrow$ névváltozat (= allonima) közül előnyben részesítettként jóváhagyott név. Egyetlen alakulatnak ugyanakkor több egységesített (= standardizált) neve is lehet. Példa: Kaapstad és Cape Town (de a Capetown forma nem egységesített).

Lásd toponym (339).

Egy adott $\rightarrow$ nyelvközösség által viszonylag széles körben használt, rendszerint a közösség hagyományaiban és irodalmában is jelentkező $\rightarrow$ exonima. Példák: Alexandrie (francia) al-Iskandarīyah (arab) helyett; Jerusalén (spanyol) Yerushalayim (héber) helyett; Peking (magyar) Beijing (kínai pinjin) helyett.

Két vagy több politikai egységre kiterjedő $\rightarrow$ földrajzi alakulat, $\mathrm{pl}$ folyó, hegylánc, neve. Példák: An-Nīl; der Rhein; Cordillera de los Andes; Alpok.

Lásd allonym (005).

(a) Testület, például személy, választmány vagy bizottság, amely a $\rightarrow$ helynevekkel kapcsolatos ügyekben tanácsadó és/vagy döntési hatáskörrel rendelkezik valamely 
233

names

conversion

234 names index

235 names survey

236 names transformation

237 national language

238 national standardization, geographical names

239 natural feature 240 noise, graphic

nominative form (of a toponym) törvényes egység, például egy állam megbízásából.

(b) Az $\rightarrow$ egységesített (= standardizált) helynevek (= toponimák) közzétételével megbízott testület.

Lásd conversion (041).

Lásd index, toponymic (138).

Lásd survey, toponymic (319).

Lásd transformation, names (349).

Lásd language, national (151). $\begin{array}{ll}\text { nemzeti egységesítés } & \text { Lásd standardization, national, } \\ \text { (= standardizáció), } & \text { geographical names (314). }\end{array}$ földrajzi névi

természetes alakulat

Lásd feature, natural (092).

zaj, grafikai

A grafikai üzenet tiszta átadását vagy fogadását gátló, akadályozó vagy elhomályosító tényezők. Példák: „hó” a televízió képernyőjén; a térkép telezsúfolása túl sürü grafikai információkkal; elmosódott térképi írás.

helynév (= toponima) Azokban a nyelvekben, amelyek alanyesete nyelvtana névszóragozást és eseteket alkalmaz, a név alakja az első (nominativusi) esetben. Példák: Berlin, nem pedig Berlins ('Berlinnek' jelentésü genitivus, birtokos eset) a németben; Budapest, nem pedig például Budapestre (a Budapest lativusa) a magyarban; Москва, nem pedig például Москвы (a Moszkva függő esete, 


\begin{tabular}{|c|c|c|c|}
\hline & & & $\begin{array}{l}\text { amely prepozícióval azt fejezi ki, } \\
\text { hogy 'Moszkvából') az oroszban. }\end{array}$ \\
\hline 241 & $\begin{array}{l}\text { non-official } \\
\text { language }\end{array}$ & nem hivatalos nyelv & Lásd language, non-official (152). \\
\hline 242 & non-vocalized & $\begin{array}{l}\text { a magánhangzó nem } \\
\text { jelölt }\end{array}$ & $\begin{array}{l}\text { Írott szó vagy szöveg, amely nem } \\
\text { tartalmaz } \rightarrow \text { magánhangzó- } \\
\text { jelölést. }\end{array}$ \\
\hline 243 & non-vowelled & $\begin{array}{l}\text { a magánhangzó nem } \\
\text { jelölt }\end{array}$ & Lásd non-vocalized (242). \\
\hline 244 & normalization & normalizálás & Lásd standardization (311). \\
\hline 245 & noun, common & név, köz-; szó, köz- & $\begin{array}{l}\text { Szó, amely egy adott típusú élö- } \\
\text { lény, hely vagy dolog bármelyikét } \\
\text { jelöli. Példák: helynév, földrajzinév- } \\
\text { tár, város. }\end{array}$ \\
\hline 246 & noun, proper & név, tulajdon- & $\begin{array}{l}\text { Szó, amely egyértelműen azonosít } \\
\text { egy személyt, helyet vagy dolgot. } \\
\text { Példák: Albert, Beijing, Budapest. }\end{array}$ \\
\hline 247 & odonym & $\begin{array}{l}\text { útnév } \\
\text { (= hodonima) }\end{array}$ & $\begin{array}{l}\text { Közlekedési útvonalak jelölésére } \\
\text { szolgáló } \rightarrow \text { tulajdonnév. Példák: Via } \\
\text { Appia (történelmi közút); Airway } \\
\text { Amber (légi forgalmi útvonal); M1 } \\
\text { (autópálya); Fleet Street; Piccadilly } \\
\text { Circus; Váci utca. A hodonima termi- } \\
\text { nus a magyarban ritkán használatos. }\end{array}$ \\
\hline 248 & $\begin{array}{l}\text { official } \\
\text { language }\end{array}$ & hivatalos nyelv & Lásd language, official (153). \\
\hline 249 & onomastics & $\begin{array}{l}\text { névtan, névkutatás, } \\
\text { névtudomány } \\
(=\text { onomasztika })\end{array}$ & $\begin{array}{l}\text { (a) Tudomány, amelynek célja a } \\
\rightarrow \text { nevek tanulmányozása. } \\
\text { (b) A névadás folyamata vagy } \\
\text { tevékenysége. (Megjegyzés: a ma- } \\
\text { gyar szakkifejezések jelentése nem } \\
\text { foglalja magában az angol terminus } \\
\text { által hordozott [b] jelentést.) }\end{array}$ \\
\hline
\end{tabular}


250 oronym hegynév, domborzati név (= oronima)

helyesírás

252 phone

beszédhang

fonéma

$\begin{array}{lll}254 & \text { phonemic } & \text { fonemikus } \\ 255 & \begin{array}{l}\text { phonetic, } \\ \text { phonetical }\end{array} & \text { fonetikus, fonetikai }\end{array}$

A terep (ideértve a tengerfeneket is) egy függőleges elrendeződésü képződményének a neve, így például hegyek, hegyvonulatok, fenékhegyek, dombok vagy felföldek nevei. Példák: Matterhorn; Gaurīśankar; Fuji San; Sierra Madre; Közép-Atlanti-hátság.

A szavak lejegyzése egy adott nyelvészeti hagyomány által előírt szabályok szerint.

A $\rightarrow$ fonetikában (= hangtanban) a beszédfolyam legkisebb észlelhető hangegysége, általában szögletes zárójelbe téve jelölik. Egy adott $\rightarrow$ fonéma $\rightarrow$ allofónoknak (= hangváltozatoknak) nevezett különböző beszédhangok által valósulhat meg. Példák: a spanyolban a „b" [ $\beta]$ a saber és [b] a Barcelona szóban.

A legkisebb hangegység egy $\rightarrow$ nyelv $\rightarrow$ fonológiai szerkezetében, amely jelentésmegkülönböztető szereppel bír, s általában ferde zárójelbe téve jelölik. Példák: /b/; /p/; / / (az angol sh-re). A gyakorlatban a fonémát $\rightarrow$ allofónoknak (= hangváltozatoknak) nevezett ejtésváltozatok valósítják meg, amelyeket általában szögletes zárójelbe téve jelölnek, például a spanyolban a /b/ fonéma megvalósulása [b] a Barcelona és [ $\beta]$ a saber szóban; vagy az [e], [ẽ] és [E] az /e/ fonéma különböző megvalósulásai. Lásd még $\rightarrow$ beszédhang.

$\mathrm{A} \rightarrow$ fonémákkal kapcsolatos.

$\mathrm{A} \rightarrow$ fonetikával (= hangtannal) kapcsolatos. 
256 phonetics fonetika

(= hangtan)

257 phonogram

fonogramma

(= hangjel)

258 phonological

fonológiai

259 phonology

fonológia

260

physical feature

természeti alakulat

261 pictogram

piktogram

262 pidgin

pidzsin
A beszélt nyelv hangjainak tanulmányozása és osztályozása. A legkisebb fonetikai egység a $\rightarrow$ beszédhang.

(a) Hango(ka)t jelölő grafikai $\rightarrow$ írásjegy (= karakter).

(b) Különösen: $\rightarrow$ piktogram, amely nem az ábrázolt tárgyhoz kapcsolódó jelentést, hanem a tárgy nevének hangzását jelöli az adott nyelvben. Példák: az egyiptomi hieroglifák piktogramjai, amikor fonetikai érték jelölésére használták őket, pl. $\square$ (szék) a p, a 'szék' jelentésű szó kezdőhangjának jelölésére.

$\mathrm{A} \rightarrow$ fonológiával kapcsolatos.

A beszédhangok tanulmányozása, különös tekintettel azok egy adott $\rightarrow$ nyelvben, illetve, egymással való összehasonlítás céljából, két vagy több nyelvben betöltött funkciójára. Lásd feature, physical (093).

Grafikai jel, amely egy tárgyat grafikai-képi hasonlóság útján jelöl, hogy a tárgyhoz kapcsolódó jelentést vagy a tárgy nevének hangzását közvetítse. Lásd még $\rightarrow$ fonogramma (= hangjel).

Viszonylag állandó megnyilatkozási forma, amely segédnyelvként fejlödött ki, s amelynek szókészlete és alkalmazási köre erősen korlátozott, és amelynek $\rightarrow$ nyelvtana, $\rightarrow$ fonológiai szerkezete és stílusa egyszerübb, mint az(ok)é a $\rightarrow$ nyelv(ek)é, amely(ek)ből kialakult. Példák: tok pisin (angol alapú pidzsin, Új-Melanéziában); bazári maláj Malajziában és Indonéziában; petit mauresque (francia alapú pidzsin, Észak-Afrikában); fanagalo 
(főként a zuluból, Dél-Afrikában).

A pidzsin, amely egy $\rightarrow$ nyelv-

közösség $\rightarrow$ anyanyelvévé válik, kreolizálódik. Lásd még $\rightarrow$ kreol.

263 pixel

pixel (= képpont)

264 place name

helynév

265 place name index

266 portability, data

267

principal

language

268

program, computer

program, számítógépes

26

270 proper name

tulajdonnév

tulajdonnév

271 radical, radix

gyökjel

272 raster mode
A ,picture element” kifejezésből alkotott $\rightarrow$ mozaikszó (= akronima); tárolási és kijelzési egység $\rightarrow$ raszteres módban.

Lásd toponym (339); name, place (b) (224).

Lásd index, place names (137).

Lásd data portability (059).

Lásd language, principal (154).

Utasítások készlete, amely a számítógépet vezérli, hogy az mely müveleteket hajtsa végre. Kapcsolódó kifejezés: $\rightarrow$ adat(ok), mellyel/ melyekkel a program müveleteket végez.

Lásd noun, proper (246).

Lásd noun, proper (246).

(a) Egy $\rightarrow$ szójelölő $\rightarrow$ írásjegy (= karakter) alapformája. Példa: a körülbelül 240 kínai alap $\rightarrow$ írásjegy (= karakter) egyike, amely értelmi kategóriát jelöl, például a „fa” írásjegye, mely a különböző típusú fákat, faanyagokat jelölő $\rightarrow$ logogramok (= szójelek) megalkotásának alapjául szolgál. (b) Lásd root (282).

A számítógépen adatok tárolása és kijelzése oszlopokba és sorokba rendezett $\rightarrow$ pixelek (= képpontok) 


\begin{tabular}{|c|c|c|c|}
\hline & & & $\begin{array}{l}\text { sürü rácshálózatán. Példa: a mü- } \\
\text { holdas képeket általában raszteres } \\
\text { módban tárolják. Kapcsolódó kife- } \\
\text { jezés: } \rightarrow \text { vektoros mód. }\end{array}$ \\
\hline 273 & $\begin{array}{l}\text { receiver } \\
\text { language }\end{array}$ & átvevő nyelv & Lásd language, target (158). \\
\hline 274 & receiver script & átvevő írás & Lásd script, target (295). \\
\hline 275 & $\begin{array}{l}\text { record, } \\
\text { computer }\end{array}$ & rekord, számítógépes & $\begin{array}{l}\text { Egyetlen aktuális tétellel kapcsola- } \\
\text { tos, egységként kezelt összefüggő } \\
\rightarrow \text { adatok számítógéppel olvasható } \\
\text { gyüjteménye. Példa: egy helynév } \\
\text { és kapcsolódó adatai, például koor- } \\
\text { dináták, jóváhagyás dátuma és a } \\
\text { név eredete. }\end{array}$ \\
\hline 276 & $\begin{array}{l}\text { rectangular } \\
\text { coordinates }\end{array}$ & $\begin{array}{l}\text { derékszögü } \\
\text { koordináták }\end{array}$ & $\begin{array}{l}\text { Lásd coordinates, rectangular } \\
(045) .\end{array}$ \\
\hline 277 & retranscription & $\begin{array}{l}\text { retranszkripció } \\
(=\text { kiejtés szerinti } \\
\text { átírás visszaalakítása) }\end{array}$ & $\begin{array}{l}\mathrm{A} \rightarrow \text { transzkripció (= kiejtés sze- } \\
\text { rinti átírás) eredményének vissza- } \\
\text { alakítása a } \rightarrow \text { forrásnyelvre. }\end{array}$ \\
\hline 278 & retransliteration & $\begin{array}{l}\text { retranszliteráció } \\
\text { (= betü szerinti átírás } \\
\text { visszaalakítása) }\end{array}$ & $\begin{array}{l}\text { A } \rightarrow \text { transzliteráció (= betủ szerinti } \\
\text { átírás) eredményének visszaalakítása } \\
\mathrm{a} \rightarrow \text { forrásnyelvi írásra. Lásd még } \\
\rightarrow \text { megfordíthatóság. }\end{array}$ \\
\hline 279 & reversibility & megfordíthatóság & $\begin{array}{l}\text { A } \rightarrow \text { transzliteráció (= betü szerinti } \\
\text { átírás) azon sajátossága, amely } \\
\text { lehető́vé teszi egy írott adat egyik } \\
\rightarrow \text { írásból vagy } \rightarrow \text { írásrendszerből } \\
\text { egy másikba való átalakítását, majd } \\
\text { ezt követően annak visszaalakítását } \\
\text { a } \rightarrow \text { forrásnyelvi írásra úgy, hogy } \\
\text { a végeredmény az eredetivel azo- } \\
\text { nos legyen. }\end{array}$ \\
\hline 280 & romanization & latin betüs átírás & 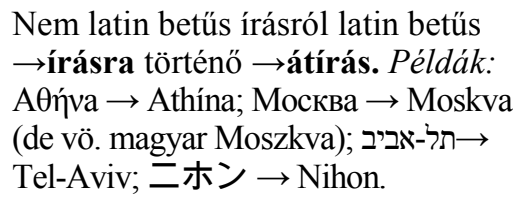 \\
\hline
\end{tabular}


romanization key

latin betüs átírást szolgáló táblázat alphabetic
Táblázat, amely egy nem latin betüs $\rightarrow$ írás $\rightarrow$ írásjegyeit $(=\mathrm{ka}-$ raktereit) a latin $\rightarrow$ ábécé megfelelő $\rightarrow$ betüivel együtt sorolja fel, beleértve a szükséges $\rightarrow$ mellékjeleket (= diakritikus jeleket) is. Példák: a latin betüs šč az orosz cirill betüs щ értékében; a latin betüs ps a görög $\Psi$ értékében (vö. ugyanakkor a kérdéses betük magyarra történő átírásakor alkalmazott scs és psz jelölésekkel). A $\rightarrow$ transzliterációs (= betü szerinti átírást szolgáló) táblázat sajátos típusa.

Alapegység megjelölése a $\rightarrow$ nyelvészetben. Példa: a szótő, amelyből egy szó származik, így például a hármas mássalhangzócsoportok a sémi szavakban, pl. n z 1 a nazala (arab 'lemegy, leereszkedik') szó vagy y r d a yarad (héber 'lemegy, leereszkedik') szó és valamennyi származékuk esetében.

Egy adott nyelven történő íráskor vagy nyomtatáskor alkalmazott grafikai jelek készlete, amelyet egy másik készlettől nem csupán a $\rightarrow$ betükép vagy a $\rightarrow$ font (= betütípus) különít el. A különféle írások csoportjai $\rightarrow$ írásrendszereket alkotnak. Példák: a latin, görög, cirill, arab, koreai, thai és héber írások a $\rightarrow$ betüírást alkalmazó írásrendszerhez tartoznak; az amhara, a japán kana és az inuktitut (eszkimó) $\rightarrow$ szótagjelölők; a kínai han és a japán kandzsi $\rightarrow$ szójelölők.

$\mathrm{A} \rightarrow$ betüírást alkalmazó

$\rightarrow$ írásrendszerhez tartozó írás, amelyben egy $\rightarrow$ betü, illetve $\rightarrow$ divagy trigráf (= két- vagy háromjegyü 
285 script, consonant

286 script, defective alphabetic script, donor

írás, átadó

script, ideographic

289 script, logographic

290 script, map

291 script, original

292 script, receiver képírás) írás,

mássalhangzó-jelölö

írás, hiányos betü- betü) elviekben egyetlen $\rightarrow$ fonémát vagy $\rightarrow$ kettőshangzót (= diftongust) jelöl. Példák: a latin, görög, cirill, thai, arab és héber betüírások, de az utóbbi kettő $\rightarrow$ hiányos, azaz alapvetően $\rightarrow$ mássalhangzó-jelölő írás.

A (betüírást alkalmazó) koreaiban a betűk grafikusan nagyjából négyzet alakú szótagegységekbe vannak rendezve.

Lásd script, defective alphabetic (286).

$\rightarrow$ Betüírás, amelyben a betűk kizárólag vagy túlnyomóan $\rightarrow$ mássalhangzókat jelölnek, a $\rightarrow$ magánhangzók jelölése nem betükkel, hanem kizárólag vagy elsősorban $\rightarrow$ kiegészítő írásjegyekkel történik, a $\rightarrow$ mássalhangzókat jelölő betük fölé, alá vagy belsejébe helyezett pontok vagy vonalak segítségével. Példák: arab és héber. Lásd még $\rightarrow$ kiegészítő írásjegy, magánhangzójelölö.

Lásd script, source (293).

Lásd script, logographic (289).

írás, ideogrammatikus (= fogalomírás,

írás, szójelölő

$\rightarrow$ Logogrammokból (= szójelekből) álló $\rightarrow$ írás, amely a $\rightarrow$ szójelölő $\rightarrow$ írásrendszerhez tartozik. Példák: kínai; japán kandzsi.

Lásd map script (189).

Lásd script, source (293).

Lásd script, target (295). 
293 script, source írás, forrásnyelvi

294 script, syllabic

írás, szótag-

írás, célnyelvi

296

segment

szegmens

297

298 semantics

szemantika

(= jelentéstan)

sequence rules sorrendiséget meghatározó szabályok $\rightarrow$ Írás, amelynek szabályai szerint egy $\rightarrow$ helynevet létrehoznak, és amely alapján a név használat céljából átalakítható egy másik írásba, melyet $\rightarrow$ célnyelvi írásnak nevezünk.

$\rightarrow$ Írás, amely a $\rightarrow$ szótagjelölő $\rightarrow$ írásrendszerhez tartozik, és amelyben minden, vagy a legtöbb $\rightarrow$ írásjegy (= karakter) egy teljes $\rightarrow$ szótagot jelöl. Példák: az etiópiai amhara; a japán katakana és hiragana; a kanadai eszkimó inuktitut $\rightarrow$ szótagírások. A koreai, bár betüírású, grafikusan és vizuálisan szótagjelölő.

$\rightarrow$ Írás, amelybe egy $\rightarrow$ helynév (= toponima) a $\rightarrow$ forrásnyelvi írásból átalakítható. Lásd még $\rightarrow$ transzliteráció (= betü szerinti átírás). Példa: a latin betüs írás a görög $\rightarrow$ latin betús átírása esetében.

$\mathrm{A} \rightarrow$ nyelvészetben bármely különálló egység, amely a beszédfolyamban azonosítható. Példák: $\rightarrow$ fonémák; $\rightarrow$ mássalhangzók; $\rightarrow$ magánhangzók.

$\mathrm{A} \rightarrow$ nyelvészet jelentéssel foglalkozó ága.

Szabályok, amelyek meghatározzák, hogy a szavak (pl. a

$\rightarrow$ földrajzi nevek egy földrajzinévtárban) milyen sorrendbe legyenek rendezve $\rightarrow$ betüik,

$\rightarrow$ szillabogramjaik (= szótagjeleik) vagy $\rightarrow$ logogramjaik (= szójeleik) sorozata tekintetében. Problémák különösen azokkal a betükkel kapcsolatban jelentkezhetnek, amelyek az $\rightarrow$ ábécérendből hagyományosan kimaradnak, vagy amelyek 
short form rövid névforma (of a name)

300

simplex name

303 simplified character

software specific element elem

308 speech

jel, mellék(= diakritikus)

egyszerü név (= karakter)

szoftver $\rightarrow$ kiegészítő írásjeggyel, illetve $\rightarrow$ mellékjellel (= diakritikus jellel) ellátottak (mint például az ä, ö, ü, $\beta$ a németben és az 1l, ñ a spanyolban), problémásak lehetnek továbbá a kötőjeles szavak.

A helynévtanban a név rövid vagy rövidített változata. Példák: Kína a Kínai Népköztársaságra vonatkozóan; Jordánia a Jordán Hásimita Királyságra vonatkozóan. Kapcsolódó kifejezés: $\rightarrow$ teljes névforma.

Lásd short form (of a name) (299).

Lásd diacritic (064).

Lásd name, simplex (227).

egyszerüsített írásjegy Lásd character, simplified (025).

$\rightarrow$ Számítógépes programok, eljárások és $\rightarrow$ adatok a számítógépes rendszerek müködésével kapcsolatban. Kapcsolódó kifejezés: $\rightarrow$ hardver.

Lásd language, source (156).

Lásd script, source (293).

A $\rightarrow$ helynév (= toponima) azon része, amely nem alkot $\rightarrow$ földrajzi köznevet, és amely a nevet megkülönbözteti más, azonos $\rightarrow$ alakulatosztályt jelölő nevektől. Tartalmazhat $\rightarrow$ névelöt és/vagy más viszonyjelentést kifejező nyelvi elemet.

Példák: Port Elizabeth; Rio Negro; Cape of Good Hope.

$\mathrm{A} \rightarrow$ nyelv szóbeli megnyilvánulása. 


$309 \begin{aligned} & \text { speech beszélöközösség } \\ & \text { community }\end{aligned}$

community

310

standard

language

311

standardization

egységesítés

(= standardizáció)

312 standardization, egységesítés geographical (= standardizáció), names
313 standardization, egységesítés international, geographical names
(= standardizáció), nemzetközi földrajzinév-
Emberek egy csoportja, amely szóban viszonylag könnyen kommunikál egy közös $\rightarrow$ nyelven vagy $\rightarrow$ nyelvváltozatban.

Lásd language, standard (157).

(a) Nyelvi szabványok és normák meghatározott készletének kialakítása egy megfelelö testület által, pl. a $\rightarrow$ helynevek egységes megadására (b) Egy adat, például egy $\rightarrow$ helynév (= toponima) megadása a fenti normákkal összhangban.

Egy vagy több adott $\rightarrow$ név elöírása egy $\rightarrow$ névtestület által, a pontos írott forma, egy meghatározott $\rightarrow$ földrajzi alakulatra való alkalmazás, valamint a névhasználat feltételeinek megadásával. Tágabb értelemben: $\rightarrow$ földrajzi nevek egységesítése (=standardizációja).

Tevékenység, amelynek célja a legnagyobb fokú gyakorlati egységesség elérése a Föld valamennyi $\rightarrow$ földrajzi nevének (valamint, tágabb értelemben, $\mathrm{a} \rightarrow$ Földön kívüli alakulatok $\rightarrow$ helyneveinek) szóbeli és írásbeli megadásában, (1) $\rightarrow$ nemzeti egységesítés (= standardizáció), és/vagy (2) nemzetközi megegyezés révén, amely kitér a különböző nyelvek és írásrendszerek közti megfeleltetésekre.

$\mathrm{A} \rightarrow$ földrajzi nevek $\rightarrow$ egységesítése (= standardizációja) egy nemzeti egység, például egy állam területén belül.

Lásd allonym, standardized (006).

315 standardized

egységesített allonym 


\begin{tabular}{|c|c|c|}
\hline $\begin{array}{l}316 \text { standardized } \\
\text { name }\end{array}$ & $\begin{array}{l}\text { egységesített } \\
\text { (= standardizált) név }\end{array}$ & Lásd name, standardized (228). \\
\hline $\begin{array}{l}\text { standardized } \\
\text { toponym }\end{array}$ & $\begin{array}{l}\text { egységesített } \\
\text { (= standardizált) } \\
\text { helynév (= toponima) }\end{array}$ & Lásd name, standardized (228). \\
\hline standard name & $\begin{array}{l}\text { egységesített } \\
\text { (= standard) név }\end{array}$ & Lásd name, standardized (228). \\
\hline survey, names & rendezés, név- & Lásd survey, toponymic (319). \\
\hline $\begin{array}{l}\text { survey, } \\
\text { toponymic }\end{array}$ & rendezés, helynév- & $\begin{array}{l}\text { Egy adott terület } \rightarrow \text { helyneveinek } \\
\text { (= toponimáinak) gyüjtésével, fel- } \\
\text { jegyzésével és feldolgozásával } \\
\text { kapcsolatos tevékenységek teljes } \\
\text { skálája. (Megjegyzés: a magyarban } \\
\text { gyakrabban a földrajzinév-rendezés } \\
\text { terminus használatos.) }\end{array}$ \\
\hline
\end{tabular}

320 syllabary szótagjelkészlet

Egy $\rightarrow$ szótagírást alkalmazó nyelv összes $\rightarrow$ szótagját jelölő

$\rightarrow$ szillabogramok (= szótagjelek) rendezett készlete. Példa: a japán katakana szillabogramjainak készlete - ア, カ, サ, タ, ナ, ハ, マ az $\mathrm{a}, \mathrm{ka}, \mathrm{sa}, \mathrm{ta}, \mathrm{na}$, ha, ma stb. jelölésére; az inuktitut ${ }^{\wedge},>,<, \cap, \supset, \subset$ a pi, pu, pa, ti, tu, ta stb. jelölésére.

321 syllabic (as a noun)

322 syllabic (as an adjective)

323 syllabic script

324 syllabification

325 syllable szótag (fönév)

szótag- (melléknév)

szótagírás

szótagolás

szótag
Lásd syllabogram (326). Az angolban túlnyomóan a többes számú syllabics forma használatos.

$\rightarrow$ Szótagokból álló vagy azokkal kapcsolatos.

Lásd script, syllabic (294).

Egy szó $\rightarrow$ szótagokra való felosztása. Példák: Val-pa-ra-i-so; O-ban.

A $\rightarrow$ beszéd egysége, amely egyetlen $\rightarrow$ magánhangzót vagy magánhangzó funkciójú elemet, illetve 


\begin{tabular}{|c|c|c|c|}
\hline & & & $\begin{array}{l}\text { egy } \rightarrow \text { kettőshangzót (= diftongust) } \\
\text { vagy hármashangzót (= triftongust) } \\
\text { tartalmaz (vagy abból áll); a szó } \\
\text { alapvető része. Példák: Ge-no-va a } \\
\text { Genova név esetében; Hei-del-berg } \\
\text { a Heidelberg név esetében; Br-no a } \\
\text { Brno név esetében. }\end{array}$ \\
\hline 326 & syllabogram & $\begin{array}{l}\text { szillabogram } \\
(=\text { szótagjel) }\end{array}$ & $\begin{array}{l}\text { Grafikai } \rightarrow \text { írásjegy (= karakter), } \\
\text { amely a } \rightarrow \text { szótagírásban egy } \\
\rightarrow \text { szótagot jelöl. }\end{array}$ \\
\hline 327 & synonym & szinonima & $\begin{array}{l}\text { Két vagy több hozzávetőlegesen } \\
\text { azonos jelentésű szó egyike. }\end{array}$ \\
\hline 328 & syntax & $\begin{array}{l}\text { szintaxis } \\
(=\text { mondattan })\end{array}$ & $\begin{array}{l}\text { A } \rightarrow \text { nyelvészet azon része, amely a } \\
\text { mondatban található szavak közti } \\
\text { kölcsönös viszonyokkal és a szavak } \\
\text { helyes elrendeződésével foglalkozik. }\end{array}$ \\
\hline 329 & target language & célnyelv & Lásd language, target (158). \\
\hline 330 & target script & célnyelvi írás & Lásd script, target (295). \\
\hline 331 & tetragraph & $\begin{array}{l}\text { tetragráf } \\
\text { (= négyjegyü betü) }\end{array}$ & $\begin{array}{l}\text { Négy, meghatározott sorrendben } \\
\text { együttesen alkalmazott } \rightarrow \text { betü egy } \\
\text { adott nyelv egyetlen } \rightarrow \text { fonológiai } \\
\text { vagy grafikus elemének jelölésére. } \\
\text { Példák: a német nyelvben a tsch a } \\
\text { /t } \text { / } \rightarrow \text { fonéma jelölésére, például a } \\
\text { Tschad névben, amely a Csád or- } \\
\text { szágnév német átírása; az angolban } \\
\text { a shch, amely az orosz щ helyett áll. }\end{array}$ \\
\hline 332 & thematic map & tematikus térkép & Lásd map, thematic (192). \\
\hline 333 & $\begin{array}{l}\text { topographic } \\
\text { category }\end{array}$ & topográfiai osztály & Lásd feature class (085). \\
\hline 334 & $\begin{array}{l}\text { topographic } \\
\text { feature }\end{array}$ & topográfiai alakulat & Lásd feature, topographic (094). \\
\hline 335 & topographic map & topográfiai térkép & Lásd map, topographic (193). \\
\hline
\end{tabular}


336 topographic topográfiai név Lásd toponym (339).

name

(a) A Föld, egy másik bolygó vagy mellékbolygó, illetve ezek egy részletének felszíni terepalakulatai, figyelembe véve a sík- és magasságbeli jellemzőket, azaz a sík- és domborzati térképen való elhelyezkedést.

(b) A fentiek leírása és grafikus megjelenítése.

338 toponomastics

339 toponym

340 toponym, standardized

A340

toponym, underground helynévtan, helynévkutatás (= toponomasztika)

helynév (= toponima)

helynév

(= toponima),

egységesített

(= standardizált)

helynév

(= toponima),

föld alatti

helynév-

(= toponima)változat

342 toponymic guidelines helynév-egységesítési irányelvek
A $\rightarrow$ helynevek (= toponimák) vizsgálatának tevékenysége és folyamata.

Egy $\rightarrow$ topográfiai alakulatra alkalmazott tulajdonnév. Összefoglaló kifejezés a $\rightarrow$ földrajzi nevekre és a $\rightarrow$ Földön kívüli nevekre.

Lásd name, standardized (228).

Egy, a föld felszíne alatt elhelyezkedő $\rightarrow$ topográfiai alakulatra alkalmazott $\rightarrow$ helynév (= toponima). Példák: x metróvonal, földalatti raktárak, 10-es szinti bányavágat, Aggteleki-barlang vagy Baradlabarlang Magyarország és Szlovákia között, Simplon alagút Svájc és Olaszország között.

Lásd allonym (005).

Lásd guidelines, toponymic (126). (Megjegyzés: a magyarban inkább a földrajzinév-egységesítési irányelvek terminus használatos.) 
343 toponymic helynévmutató Lásd index, toponymic (138).

index egy tulajdonnév) köznévből vagy más szófajú szóból való megalkotásának aktusa. Példák: az angliai Bath ('fürdő') helységnév megalkotása az ottani római kori fürdőkre való utalással; Irak az 'Irāq szóból (arab, egy tenger vagy nagyobb folyó partja). A $\rightarrow$ köznevesült helynév esetében ugyanakkor tulajdonnév válik köznévvé, mint például gejzír (szökőforrás) az izlandi Geysir névből és meander (hurokkanyar) a törökországi Büyük Menderes folyó latin nevéből (Maeander).

344 toponymy (a) helynévtan, helynévkutatás (= toponomasztika)

(b) helynévállomány (a) Általánosan a $\rightarrow$ helynevek (= toponimák) és különösen a $\rightarrow$ földrajzi nevek tanulmányozásával foglalkozó tudomány.

(b) Egy adott terület $\rightarrow$ helyneveinek (= toponimáinak) összessége. (Megjegyzés: az angolban a toponymy terminus használatos mindkét értelemben.)

345 traditional name hagyományos név

A345 transboundary határt átívelő név name transzkripció (= kiejtés szerinti átírás)
Lásd name, traditional (230).

Lásd name, transboundary (A230).

(a) A nevek kiejtés szerinti $\rightarrow$ átírásának módszere különböző nyelvek között, amely során a $\rightarrow$ forrásnyelv hangjai az adott $\rightarrow$ célnyelvre és annak sajátos $\rightarrow$ Írására jellemző szabályok szerint kerülnek lejegyzésre, rendszerint anélkül, hogy kiegészítő $\rightarrow$ mellékjeleket (= diakritikus jeleket) használnának. 
347 transcription alphabet

348 transcription key transzkripciós (= kiejtés szerinti átírást szolgáló) ábécé

transzkripciós (= kiejtés szerinti átírást szolgáló) táblázat

349 transformation, átalakítás, névnames

(b) E folyamat eredménye. Példák: török Ankara $\rightarrow$ görög A $\gamma \kappa \alpha \rho \alpha$; orosz Щукино $\rightarrow$ angol Shchukino. A transzkripció általában nem megfordítható folyamat. Lehetséges, hogy a $\rightarrow$ retranszkripció (= kiejtés szerinti átírás visszaalakítása) (pl. számítógép által) az eredetitől eltérő formát eredményez, például a fenti eseteket tekintve a törökben Agkara, az oroszban Шчукино alakokat. Ugyanakkor a kínai pinjin latin betűs átírását - bár írások közötti átalakítás, de kiejtés szerinti és nem megfordítható - szintén transzkripciónak, nem pedig $\rightarrow$ transzliterációnak (= betű szerinti átírásnak) tekintik. Lásd még $\rightarrow$ transzkripciós (= kiejtés szerinti átírást szolgáló) táblázat.

Lásd alphabet, transcription (011).

Táblázat, amely egy adott $\rightarrow$ forrásnyelv írásjegyeit sorolja fel a megfelelö $\rightarrow$ célnyelvi írásjegyekkel együtt. Példák: angol sh és magyar s megfeleltetés; német sch és holland sj megfeleltetés; de akár a latin bei és a kínai 贝北陂卑背倍碑 megfeleltetés is. Lásd még $\rightarrow$ transzkripció (= kiejtés szerinti átírás).

A helynévtanban a $\rightarrow$ helynevek (= toponimák) $\rightarrow$ fordítását, $\rightarrow$ transzkripcióját ( $=$ kiejtés szerinti átírását) és $\rightarrow$ transzliterációját (= betü szerinti átírását) magában foglaló általános kifejezés. A két utóbbi kifejezésre együttesen az

$\rightarrow$ átírás terminus használatos. 
350 translation

fordítás

351

translingual data interchange

nyelvek közötti adatcsere

transliteration

transzliteráció

(= betü szerinti átírás) (a) Folyamat, melynek során a $\rightarrow$ forrásnyelvben hordozott jelentést $\mathrm{a} \rightarrow$ célnyelv szavaival fejezzük ki.

(b) E folyamat eredménye. A helynévtanban olykor csak a név $\rightarrow$ földrajzi köznévi elemére alkalmazzák.

Példák: Lake Como (az olasz Lago di Como angol fordítása); Mount Fuji (a japán Fuji San angol fordítása).

Lásd data interchange, translingual (057).

(a) Különböző $\rightarrow$ betüírások és $\rightarrow$ szótagírások közti $\rightarrow$ névátírásra alkalmazott módszer, melyben a $\rightarrow$ forrásnyelvi írás minden $\rightarrow$ írásjegyét (= karakterét) vagy $\rightarrow$ di-, tri- és tetragráfját (= két-, három- és négyjegyü betűjét) a $\rightarrow$ célnyelvi írásban elviekben egy írásjegy, di-, tri-, tetragráf, vagy egy $\rightarrow$ mellékjel (= diakritikus jel), illetve ezek kombinációja képviseli. A transzliteráció (= betű szerinti átírás) a $\rightarrow$ transzkripciótól (= kiejtés szerinti átírás) eltérően a teljes $\rightarrow$ megfordíthatóságot igyekszik megvalósítani (bár nem feltétlenül éri el), és $\rightarrow$ transzliterációs (= betü szerinti átírást szolgáló) táblázat mellékelésével kell kivitelezni. (b) E folyamat eredménye. Példák (zárójelben a magyar $\rightarrow$ exonima): Владивосток $\rightarrow$ Vladivostok [Vlagyivosztok]; A $\theta \dot{v} v \alpha \rightarrow$ Athína [Athén].

353 transliteration alphabet

transzliterációs (= betü szerinti átírást szolgáló) ábécé

354 transliteration transzliterációs key
(= betű szerinti átírást szolgáló) táblázat
Lásd alphabet, transliteration (012).

Táblázat, amely egy adott $\rightarrow$ forrásnyelvi írás $\rightarrow$ írásjegyeit (= karaktereit) sorolja fel a $\rightarrow$ célnyelvi írás megfelelő írásjegyeivel 
355

trigraph

356 typeface

betűkép

A356 underground toponym

föld alatti helynév (= toponima) undersea feature

fenékdomborzati alakulat

358 UNGEGN

UNGEGN

359 unvocalized

a magánhangzó nem jelölt

360 unvowelled

a magánhangzó nem jelölt

$361 \quad$ UTM grid

UTM-hálózat együtt. $\rightarrow$ Átírási táblázatnak is nevezik. Példák: latin po (nem pedig bo) a japán ポ katakanára; cirill д a latin d betüre; héber $\bullet$ (nem pedig $\Omega$ ) a thai ต-re.

Három egymást követő betü, amely egyetlen $\rightarrow$ fonémát jelöl. Példa: a német nyelvben az sch az / / fonéma jelölésére.

Egy $\rightarrow$ ábécé vonatkozásában az összes nyomtatott $\rightarrow$ írásjegy (= karakter) egy készletének stílusa vagy dizájnja, a méretre való tekintet nélkül. Példák: Times New Roman; Univers bold italic. Lásd még $\rightarrow$ font (= betütípus).

Lásd toponym, underground (A340).

Lásd feature, undersea (095).

Az ENSZ Földrajzi Névi Szakértői Csoport angol megnevezéséből (United Nations Group of Experts on Geographical Names) alkotott $\rightarrow$ mozaikszó (= akronima).

Lásd vocalization (368).

Lásd vocalization (368).

Univerzális Transzverzális Mercator (Universal Transverse Mercator) háló, $\rightarrow$ derékszögü koordináták síkbeli hálózata, amelyet térképekre nyomtatnak az elhelyezkedés meghatározásának megkönnyítésére. A Föld teljes felszínét 60 meridiánzónára osztja fel, 6 hosszúsági fokonként. A zónák 


\begin{tabular}{|c|c|c|c|}
\hline & & & $\begin{array}{l}\text { 1-től } 60 \text {-ig vannak számozva a } \\
\text { nemzetközi dátumvonaltól kelet } \\
\text { felé haladva. }\end{array}$ \\
\hline 362 & $\begin{array}{l}\text { variant } \\
\text { character }\end{array}$ & $\begin{array}{l}\text { változat, írásjegy- } \\
\text { (= karakter-) }\end{array}$ & Lásd character, variant (026). \\
\hline 363 & variant name & névváltozat & Lásd allonym (005). \\
\hline 364 & vector mode & vektoros mód & $\begin{array}{l}\text { A grafikus információk (pontok, } \\
\text { vonalak, poligonok) tárolása és } \\
\text { kijelzése a számítógépen (általában } \\
\text { derékszögü) koordinátáik által } \\
\text { meghatározott és megcímzett pon- } \\
\text { tok segítségével. Kapcsolódó kife- } \\
\text { jezés: } \rightarrow \text { raszteres mód. }\end{array}$ \\
\hline 365 & $\begin{array}{l}\text { vehicular } \\
\text { language }\end{array}$ & közvetítő nyelv & Lásd language, vehicular (159). \\
\hline 366 & vernacular & $\begin{array}{l}\text { vernakuláris } \\
(=\text { anyanyelv-) } \\
\text { változat }\end{array}$ & $\begin{array}{l}\rightarrow \text { Nyelv vagy } \rightarrow \text { nyelvváltozat, } \\
\text { amelyet anyanyelvként használnak } \\
\text { egy adott területen, és különbözhet } \\
\text { a } \rightarrow \text { köznyelvtől. }\end{array}$ \\
\hline 367 & vocabulary & szókészlet & $\begin{array}{l}\text { (a) Egy nyelv szavainak listája. } \\
\text { (b) Egy adott egyén szókincse. } \\
\text { Lásd még } \rightarrow \text { lexikon. }\end{array}$ \\
\hline 368 & vocalization & magánhangzó-jelölés & 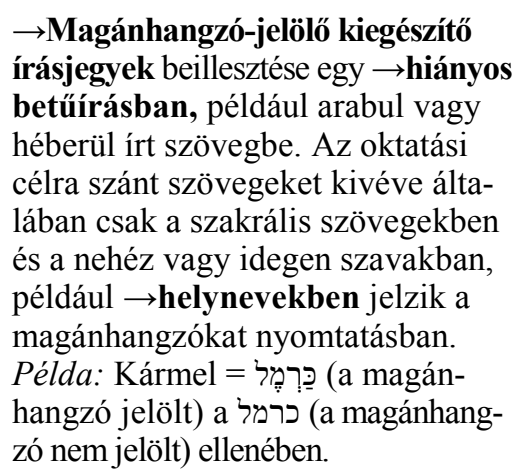 \\
\hline 369 & vocalized & a magánhangzó jelölt & Lásd vocalization (368). \\
\hline 370 & vowel & magánhangzó & $\begin{array}{l}\text { A beszédhangok két nagy osztályának } \\
\text { egyike (mely a } \rightarrow \text { kettőshangzókat }\end{array}$ \\
\hline
\end{tabular}


[= diftongusokat] és a hármashangzókat [= triftongusokat] is magában foglalja), amelyhez tartozó elemek esetében a képzés során a garat-, illetve a szájüreg nem záródik el és nem is szükül súrlódást okozó résnyire. A magánhangzó a $\rightarrow$ szótag kiemelkedően fontos része. Példák: /a/, /e/, /i/, /o/, /u/. Kapcsolódó kifejezés: mássalhangzó.

371 vowel letter magánhangzó-jelölő betü

372 vowel marker magánhangzó-jelölő kiegészítő írásjegy

373 vowel point magánhangzó-jelölő pont

374 vowelled

375 writing system a magánhangzó jelölt

írásrendszer
Lásd letter, vowel (163).

Lásd marker, vowel (196).

Lásd vowel marker (372).

Lásd vocalization (368).

Egy nyelv $\rightarrow$ fonológiai és $\rightarrow$ morfológiai elemei megjelenítésének módszere olyan grafikai jelek készletével, amelyek $\rightarrow$ ábécét, $\rightarrow$ szótagjelkészletet vagy $\rightarrow$ szójelkészletet alkotnak, $\rightarrow$ betüírást, $\rightarrow$ szótagírást alkalmazó, illetve $\rightarrow$ szójelölő írásrendszerben. Egy írásrendszer $\rightarrow$ írásokból áll. 


\section{Magyar-angol terminusmutató az UNGEGN-szójegyzékhez \\ Hungarian-English Term Index of the UNGEGN Glossary}

\section{Magyar / Hungarian}

A, Á

ábécé

ábécé, átírási

ábécé, transzkripciós (= kiejtés szerinti átírást szolgáló)

ábécé, transzliterációs (= betű szerinti átírást szolgáló)

adat

adatbázis, digitális

adatbázis, digitális helynévi

adatbázis-kezelő rendszer

adatcsere, nyelvek közötti

adatelem

adathordozhatóság

adatkönyvtár

adatmező

adattétel

alakulat, fenékdomborzati

alakulat, Földön kívüli

alakulat, földrajzi

alakulat, mesterséges

alakulat, természetes

alakulat, természeti

alakulat, topográfiai

alakulat, vízrajzi
Angol / English

alphabet $\quad 008$

alphabet, conversion $\quad 010$

alphabet, transcription $\quad 011$

alphabet, transliteration $\quad 012$

data 049

data base (also database), digital $\quad 050$

data base, digital toponymic 051

data base management system $\quad 052$

data interchange, translingual 057

data element 055

data portability 059

data dictionary 053

data directory $\quad 054$

data field 056

data item 058

feature, undersea $\quad 095$

feature, extraterrestrial $\quad 088$

feature, geographical 089

feature, cultural 087

feature, man-made $\quad 091$

feature, natural $\quad 092$

feature, physical 093

feature, topographic $\quad 094$

feature, hydrographic $\quad 090$ 


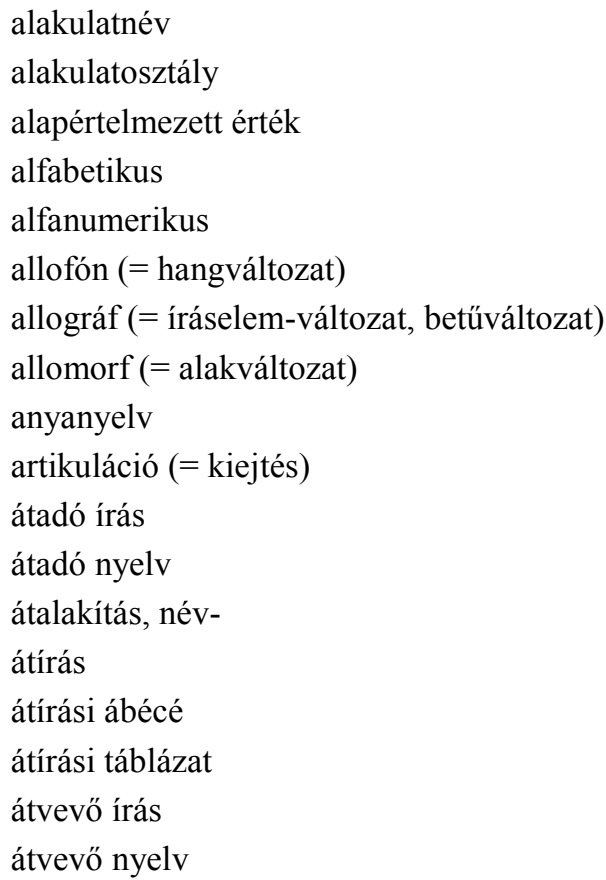

\section{B}

beszéd

beszédhang

beszédközösség

betü

betü, alap-

betü, magánhangzó-jelölö

betü, mássalhangzó-jelölő

betüírás

betük, alap-

betük, különleges

betükép

betürend

betürendet meghatározó szabályok

C

célnyelv

$\begin{array}{ll}\text { feature name } & 086 \\ \text { feature class } & 085 \\ \text { default value } & 060 \\ \text { alphabetic } & 009 \\ \text { alphanumeric } & 016 \\ \text { allophone } & 007 \\ \text { allograph } & 003 \\ \text { allomorph } & 004 \\ \text { mother tongue } & 204 \\ \text { articulation } & 019 \\ \text { donor script } & 075 \\ \text { donor language } & 074 \\ \text { transformation, names } & 349 \\ \text { conversion } & 041 \\ \text { conversion alphabet } & 042 \\ \text { conversion table } & 043 \\ \text { receiver script } & 274 \\ \text { receiver language } & 273\end{array}$

speech $\quad 308$

phone 252

speech community $\quad 309$

letter $\quad 160$

letter, basic $\quad 161$

letter, vowel 163

letter, consonant $\quad 162$

alphabetic script 013

letters, cardinal $\quad 167$

letters, special $\quad 168$

typeface $\quad 356$

alphabetic sequence $\quad 014$

alphabetic sequence rules 015

target language 
célnyelvi írás

cím

\section{D}

derékszögü koordináták

digitális adatbázis

digitális helynévi adatbázis

digráf (= kétjegyü betü)

\section{$\mathbf{E}$}

egységesített (= standard) név

egységesítés (= standardizáció)

egységesítés (= standardizáció), földrajzinév-

egységesítés (= standardizáció), nemzeti

földrajzinév-

egységesítés (= standardizáció), nemzetközi

földrajzinév-

egységesített (= standardizált) névváltozat

(= allonima)

egységesített (= standardizált) helynév

(= toponima)

egységesített (= standardizált) név

egyszerü név

egyszerüsített írásjegy (= karakter)

emlékeztető név

endonima

endonima, egységesített (= standardizált)

engedélyezett név

entitás, topográfiai

eponima

exonima

\section{F}

fájl, számítógépes

fájlformátum

fenékdomborzati alakulat

firmware (= belső vezérlőprogram) target script

330

address

002

rectangular coordinates

276

digital data base

068

digital toponymic data base

069

digraph

072

standard name

standardization

standardization, geographical names

standardization, national,

geographical names

standardization, international,

geographical names

standardized allonym

standardized toponym

standardized name

simplex name

302

simplified character

303

commemorative name

A031

endonym

076

endonym, standardized

authorized name

A019

entity, topographic

eponym

079

exonym

081

file, computer

098

file format

097

undersea feature

357

firmware

099 


fokhálózat
fonéma
fonemikus
fonetika
fonetikus, fonetikai
fonogramma (= hangjel)
fonológia
fonológiai
font (= betütípus)
fordítás
formátum
formátum, fájl-
formátum, számítógépes
forrásnyelv
forrásnyelvi írás
fö nyelv
föld alatti helynév (= toponima)
Földön kívüli alakulat
Földön kívüli név
földrajzi alakulat
földrajzi entitás
földrajzi köznév
földrajzi köznévi elem
földrajzi köznévi elem, hamis
földrajzi név
földrajzi szótár
földrajzinév-mutató
földrajzinév-egységesítés (= standardizáció)
földrajzinév-tár
földrajzinév-tár, több írásrendszerü
földrajzinév-tár, többnyelvü
for

\section{G}

geoinformációs rendszer (GIS)

geonima 
GIS

graféma

grafikai forma
GIS

grapheme

graphic form

\section{GY}

gyökjel

radical, radix

H

hagyományos név

traditional name

hálózat, topográfiai (= térképhálózat)

grid, topographic

125

hamis földrajzi köznévi elem

hardver

false generic element

084

hardware

127

határt átívelő név

transboundary name

hegynév, domborzati név (= oronima)

oronym

helyesírás

orthography

251

helyi név

local name

178

place name

264

helynév (= toponima)

toponym

339

nominative form (of a toponym)

A240

toponym, standardized

helynév (= toponima), egységesített

(= standardizált)

helynév (= toponima), föld alatti

toponym, underground

A340

helynév (= toponima), megalkotása

toponymization

A343

toponym, variant

toponymy

344

helynévállomány

helynév-egységesítési irányelvek

toponymic guidelines

342

place name index

265

helynévmutató

toponymic index

343

helynévtan, helynévkutatás

(= toponomasztika)

toponomastics,

338 ,

toponymy

344

defective alphabetic script $\quad 061$

official language $\quad 248$

lunar name $\quad 184$

homonym 130

portability, data 266 


\section{I, Í}

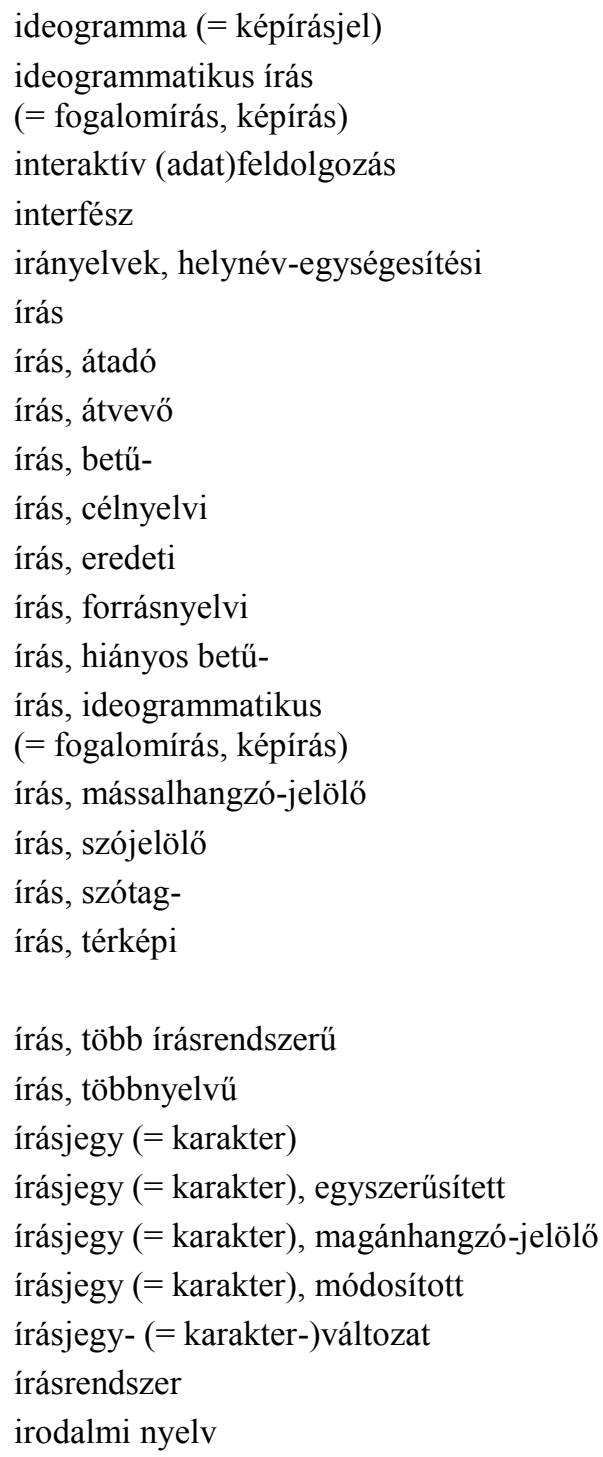


$\mathbf{K}$

készlet, szójel-

két írásrendszerű

kétnyelvüség (= bilingvizmus)

kettőshangzó (= diftongus)

kettősnyelvü

kettősnyelvüség (= diglosszia)

kiegészítő írásjegy

kiegészítő írásjegy, magánhangzó-jelölő

kisebbségi név

kisebbségi nyelv

kódolt jelölés

koordináták, derékszögü

koordináták, földrajzi

koordináták, topográfiai

koronima

kötegelt (adat)feldolgozás

kötőjelezés

köznevesült helynév

köznyelv

közvetítő nyelv

kreol

L

latin betüs átírás

latin betűs átírást szolgáló táblázat

leíró kifejezés

lexikon

ligatúra (= ikerbetü)

lingua franca

logogram (= szójel)

M

magánhangzó

magánhangzó jelölt, a lexicon, logographic $\quad 170$

biscriptual 022

bilingualism 021

diphthong 073

diglossic 071

diglossia $\quad 070$

marker 195

marker, vowel 196

minority name 199

minority language $\quad 198$

coded representation $\quad 030$

coordinates, rectangular $\quad 045$

coordinates, geographical $\quad 044$

coordinates, topographic 046

choronym 028

batch processing $\quad 020$

hyphenization, also hyphenation $\quad 133$

epotoponym 080

standard language $\quad 310$

vehicular language $\quad 365$

creole 047

romanization 280

romanization key 281

descriptive term 062

lexicon $\quad 169$

ligature $\quad 171$

lingua franca $\quad 172$

logogram 179

vowel $\quad 370$

vocalized $\quad 369$

vowelled $\quad 374$ 
magánhangzó nem jelölt, a

magánhangzó-jelölés

magánhangzó-jelölő betü

magánhangzó-jelölő kiegészítő írásjegy

magánhangzó-jelölő pont

mássalhangzó

mássalhangzó-jelölő betü

mássalhangzó-jelölő írás

megfordíthatóság

megjelölés

megkülönböztető elem

mellékjel (= diakritikus jel)

menü, számítógépes

mesterséges alakulat

mezö, adat-

módosított írásjegy (= karakter)

morféma

morfológia (= alaktan)

morfológiai

mozaikszó (= akronima)

mutató, helynév-

mutató, helynév-

mutató, név-

\section{$\mathbf{N}$}

nem hivatalos nyelv

nemzeti nyelv

nemzeti egységesítés (= standardizáció),

földrajzi névi

nemzetközi egységesítés (= standardizáció)

nemzetközi fonetikai ábécé, IPA (= APhI) non-vocalized

non-vowelled

unvocalized

243

unvowelled

359

360

vocalization $\quad 368$

vowel letter $\quad 371$

vowel marker $\quad 372$

vowel point $\quad 373$

consonant 037

consonant letter $\quad 038$

consonant script 039

reversibility 279

designation 063

specific element $\quad 307$

diacritic 064

diacritical mark, diacritical sign $\quad 065$

menu, computer 197

cultural feature $\quad 048$

man-made feature $\quad 185$

field, data 096

modified character 200

morpheme 201

morphology 203

morphological 202

acronym 001

index, place names $\quad 137$

index, toponymic 138

index, names 136

non-official language $\quad 241$

national language $\quad 237$

national standardization, $\quad 238$

geographical names

international standardization $\quad 144$

International Phonetic Alphabet, IPA 143 
népnév (= etnonima)

név

név, alternatív

név, egyszerü

név, elsődleges

név, emlékeztető

név, engedélyezett

név, Földön kívüli

név, földrajzi

név, hagyományos

név, határt átívelő

név, hely-

név, helyi

név, hivatalos

név, holdfelszíni

név, jóváhagyott

név, kisebbségi

név, hagyományos

név, köz-; szó, köz-

név, öshonos

név, összetett

név, egységesített (= standard)

név, egységesített (= standardizált)

név, tengeri

név, tó-

név, topográfiai

név, történeti

név, tulajdon-

név-, változat (= allonima)

névátalakítás

névátírás

névelő

névrendezés ethnonym

A080

name

209

name, alternative

210

name, simplex

227

name, primary

225

name, commemorative

B211

name, authorized

A211

name, extraterrestrial

215

name, geographical

216

conventional name

040

name, traditional

230

name, transboundary

A230

name, place

224

name, local

219

name, official

223

name, lunar

220

name, approved

211

name, minority

222

name, conventional

214

noun, common

245

name, indigenous

218

name, composite

name, compound

212

213

name, standard

A227

name, standardized

228

name, maritime

221

name, lacustrine

A218

name, topographic

229

name, historical

217

name, proper

226

noun, proper

246

name, variant

231

names transformation

236

names conversion

233

article

018

names survey 


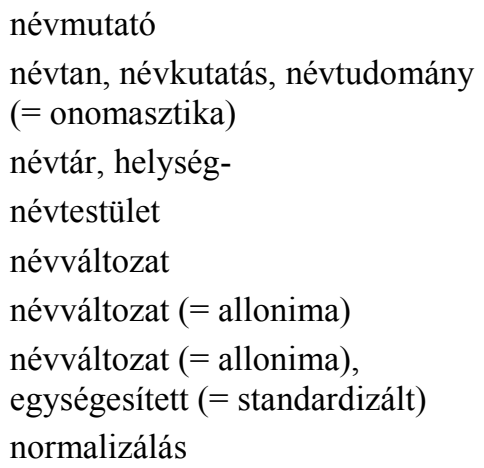

$\begin{array}{lc}\text { names index } & 234 \\ \text { onomastics } & 249 \\ & \\ \text { gazetteer, place names } & 109 \\ \text { names authority } & 232 \\ \text { variant name } & 363 \\ \text { allonym } & 005 \\ \text { allonym, standardized } & 006 \\ & \\ \text { normalization } & 244\end{array}$

language

language, donor 147

language, receiver $\quad 155$

language, target $\quad 158$

language, source $\quad 156$

language, principal $\quad 154$

language, official 153

language, literary $\quad 149$

language, minority $\quad 150$

language, standard $\quad 157$

language, vehicular $\quad 159$

language, non-official or unofficial 152

language, national 151

language, indigenous $\quad 148$

language, colloquial $\quad 146$

translingual data interchange $\quad 351$

linguistics $\quad 176$

linguistic region $\quad 175$

linguistic community $\quad 174$

grammar $\quad 121$

linguistic area $\quad 173$

dialect 066

class, feature 
Ö, Ő

öshonos név

indigenous name

140

öshonos nyelv

indigenous language

139

összetett név

composite name

032

compound name

033

$\mathbf{P}$

pidzsin

pidgin

262

piktogram

pictogram

261

pixel (= képpont)

pixel

263

program, számítógépes

program, computer

268

R

raszteres mód

raster mode

272

rekord, számítógépes

record, computer

rendezés, helynév-

survey, toponymic

319

rendezés, név-

survey, names

318

retranszkripció (= kiejtés szerinti átírás

retranscription

aalakítasa)

retransliteration

278

visszaalakítása)

rövid megnevezés

short title

300

rövid névforma

short form (of a name)

299

S

sorrendiséget meghatározó szabályok

sequence rules

SZ

számítógépes fájl

computer file 034

számítógépes program

computer program 035

számítógépes rekord

computer record

036

szegmens

segment

296

szemantika (= jelentéstan)

semantics

297

személynév (= antroponima)

anthroponym

017

szillabogram (= szótagjel)

syllabogram

326

szinonima

synonym

327

szintaxis (= mondattan)

syntax 


\begin{tabular}{l} 
szoftver \\
szójegyzék \\
szójelkészlet \\
szójelölö \\
szójelölö írás \\
szókészlet \\
szótag \\
szótag (fönév) \\
szótag- (melléknév) \\
szótagírás \\
szótagjelkészlet \\
szótagolás \\
szótár, földrajzi \\
T \\
társalgási nyelv \\
teljes megnevezés \\
teljes névforma \\
tematikus térkép \\
tengeri név \\
térkép, tematikus \\
térkép, topográfiai \\
térkép, több írásrendszerű \\
térkép, többnyelvü \\
térképi írás \\
térképi írás, több írásrendszerü \\
térképi írás, többnyelvű \\
térképi névírás \\
természetes alakulat \\
természeti alakulat \\
tetragráf (= négyjegyü betü) \\
tónév \\
topográfia \\
topográfiai térkép \\
topográfiai alakulat \\
topográfiai név \\
\hline
\end{tabular}

$\begin{array}{ll}\text { software } & 304 \\ \text { glossary } & 120 \\ \text { logographic lexicon } & 181 \\ \text { logographic } & 180 \\ \text { logographic script } & 182 \\ \text { vocabulary } & 367 \\ \text { syllable } & 325 \\ \text { syllabic (as a noun) } & 321 \\ \text { syllabic (as an adjective) } & 322 \\ \text { syllabic script } & 323 \\ \text { syllabary } & 320 \\ \text { syllabification } & 324 \\ \text { dictionary, geographical } & 067\end{array}$

colloquial language $\quad 031$

full title 104

long form (of a name) 183

thematic map $\quad 332$

maritime name 194

map, thematic 192

map, topographic 193

map, multiscriptual 188

map, multilingual 187

map script 189

map script, multiscriptual $\quad 191$

map script, multilingual 190

map lettering $\quad 186$

natural feature $\quad 239$

physical feature $\quad 260$

tetragraph 331

lacustrine name A144

topography 337

topographic map $\quad 335$

topographic feature $\quad 334$

topographic name $\quad 336$ 
topográfiai osztály

tő

több írásrendszerü földrajzinév-tár

több írásrendszerü térkép

többnyelvü földrajzinév-tár

többnyelvü térkép

történeti név

transzkripció (= kiejtés szerinti átírás)

transzkripciós (= kiejtés szerinti átírást szolgáló) ábécé

transzkripciós (= kiejtés szerinti átírást szolgáló) táblázat

transzliteráció (= betű szerinti átírás)

transzliterációs ( $=$ betü szerinti átírást szolgáló) ábécé

transzliterációs (= betü szerinti átírást szolgáló) táblázat

trigráf (= háromjegyü betü)

tulajdonnév

\section{$\mathbf{U}, \mathbf{U}$}

UNGEGN

UTM hálózat

útnév (= hodonima)

V

változat, írásjegy- (= karakter-)

vektoros mód

vernakuláris (= anyanyelv-) változat

víznév (= hidronima)

vízrajzi alakulat

$\mathbf{Z}$

zaj, grafikai topographic category

333

root

282

multiscriptual gazetteer

207

multiscriptual map

208

multilingual gazetteer

205

multilingual map

206

historical name

128

transcription

346

transcription alphabet

347

transcription key

348

transliteration

352

transliteration alphabet

353

transliteration key

354

trigraph

355

proper name

269

proper noun

270

UNGEGN

358

UTM grid

361

hodonym

129

odonym

247

variant character $\quad 362$

vector mode $\quad 364$

vernacular $\quad 366$

hydronym 132

hydrographic feature $\quad 131$

noise, graphic 